



\section{Estudios Humanísticos}

Filología

35 [2013] 



\section{Estudios Humanísticos \\ Filología \\ $\mathbf{N}^{0} 35$ [2013]}

ISSN: 0313-1329

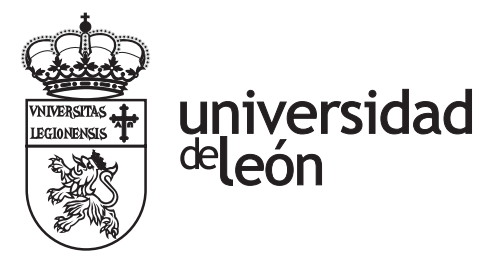

Revista de los Departamentos de Filología Hispánica y Clásica y Filología Moderna de la Facultad de Filosofía y Letras

León, 2013 


\title{
ESTUDIOS HUMANÍSTICOS. FILOLOGÍA
}

Revista de los Departamentos de Filología Hispánica y Clásica y Filología Moderna

Universidad de León

\section{DIRECTOR}

María Asunción Sánchez Manzano

\section{SECRETARIO}

César F. Gutiérrez Viñayo

\section{CONSEJO DE REDACCIÓN \\ José María Balcells Doménech \\ María Luzdivina Cuesta Torre}

\author{
Imelda Martín Junquera \\ Marisa Fernández López \\ Manuel Seoane Rodríguez
}

\section{COMITÉ CIENTÍFICO}

Antonio Chicharro Chamorro. Universidad de Granada, Francisco Javier Díez de Revenga. Universidad de Murcia, José María Fernández Cardo. Universidad de Oviedo, Fernando Galván Reula. Universidad de Alcalá, Salvador Gutiérrez Ordóñez. Universidad de León, José Antonio Pascual Rodríguez. Universidad Carlos III de Madrid, Guillermo Rojo Sánchez. Universidad de Santiago de Compostela, J. A. G. Ardila. Universidad de Edimburgo, Viçen Beltrán. Università di Roma, La Sapienza, Isabel Velázquez Soriano. Universidad Complutense Madrid, Concepción Fernández Martínez. Universidad de Sevilla

\section{Envío de artículos}

\section{ESTUDIOS HUMANÍSTICOS. FILOLOGÍA}

Departamento de Filología Hispánica y Clásica y Departamento de Filología Moderna

Facultad de Filosofía y Letras

Universidad de León

$$
24071 \text { León }
$$

Tlfn: 987-291113. Fax: 987-291154

e-mail: asanm@unileon.es

Suscripciones, pedidos, intercambio y correspondencia

Secretariado de Publicaciones

Edificio de Servicios

Campus de Vegazana s/n

Universidad de León

24071 León

Periodicidad: Anual

\section{Contenido}

Estudios originales, monográfico y reseñas.

El próximo número de Estudios Humanísticos. Filología será elaborado en Open Journal System

\author{
(c) Universidad de León \\ Área de Publicaciones \\ (c) Los autores \\ ISSN: 0313-1329 \\ Depósito Legal: LE-212-1993 \\ Maquetación e impresión: \\ Imprenta Kadmos
}




\section{ÍNDICE}

\section{[MONOGRÁFICO "LA INFLUENCIA DE LA FÁBULA ESÓPICA EN LA LITERATURA EUROPEA”]}

Cuaderno monográfico $\mathrm{n}^{\circ}$ 4. (Coordinación y edición de María Luzdivina Cuesta Torre)

Presentación: María Luzdivina Cuesta Torre

TERESA ARAUJO, Práticas esópicas em português (séculos XVII-XVIII)

ANA MARÍA MARIÑO ARIAS, De Grecia a Narnia: la fábula del león y el ratón fuera de las colecciones de fábulas

JOSÉ ENRIQUE MARTÍNEZ FERNÁNDEZ, Una mirada sobre la fábula española del siglo XIX. Las fábulas de Pascual Fernández Baeza

JUAN LUIS MONREAL PÉREZ, El uso didáctico de la fábula en la literatura renacentista alemana

ANDRÉS MONTANER BUENO, Una selección de fábulas de Esopo y de la posterior tradición española: análisis y posibilidades didácticas de las mismas en las aulas de educación primaria

ANA PAIVA MORAIS, A inscriçao da 'Vida de Esopo' nas primeiras colecçoes de fábulas em português: Livro de Exopo (séc. XIV) e Vida e fábulas do insigne fabulador grego Esopo traduzidas por Manuel Mendes da Vidigueira (1603/1643)

RICARDO PIÑERO MORAL, De fábulas y bestiarios: la estética de los animales en la Edad Media

TOMASA PASTRANA SANTAMARTA, Presencia y ecos de fábulas esópicas en el Baldo

MARÍA SÁNCHEZ PÉREZ, Tradición y modernidad: la fábula ‘La rapoza se va al Hadjilik' en el periódico sefardí El konsejero (Salónica 1913)

\section{[ESTUDIOS]}

INMACULADA LÓPEZ CALAHORRO, Francisco Ayala y el humanismo del exilio

FRANCISCO JIMÉNEZ CALDERÓN, Sobre la estructura discursiva del texto poético: la lengua visual de Huidobro en El espejo del agua 


\section{[RESEÑAS]}

Manuel Rico, Fugitiva ciudad (Juan Carlos Abril)

Clara I. Martínez Cantón, El ritmo como clave del verso en Antonio Colinas. Elementos rítmicos no métricos (Nuria Sánchez Villadangos)

Séneca, Tragedias completas, Edición y traducción de Leonor Pérez Gómez (Juan Carlos Abril)

Antonio Chas Aguión, Categorías poéticas minoritarias en el cancionero castellano del siglo XV (Ana María Mariño Arias)

$177-178$

Rafael Fombellida, Violeta profundo (Juan Carlos Abril)

$179-180$

Manuel Cifo González (ed.) Las cuatro estaciones. Homenaje a Pedro García Montalvo (Celia Ropero Serrano)

Francisco Arenas Dolç (ed.) Retórica y democracia. Perspectivas críticas sobre el estado de la investigación (María Asunción Sánchez Manzano) 


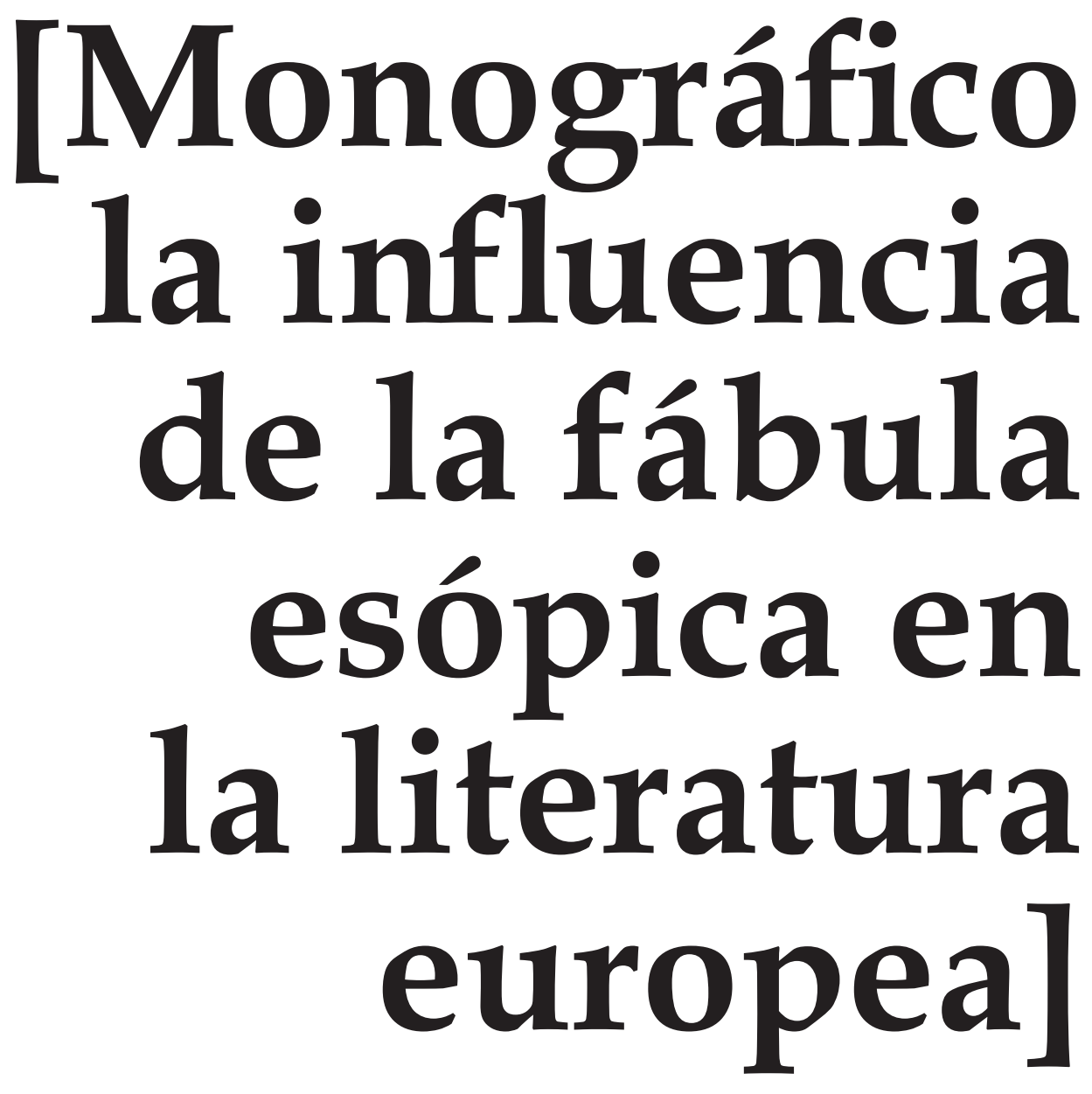





\title{
CuAderno MONOGRÁFICO N ${ }^{\mathrm{O}} 4$
}

\author{
"La influencia de la fábula esópica \\ en la literatura europea"
}

(Coordinación y edición de

María Luzdivina Cuesta Torre) 



\section{PRESENTACIÓN DEL NÚMERO MONOGRÁFICO}

La especie humana se caracteriza, entre otros rasgos que la diferencian de otros animales, por ser la única que busca la relación con otras especies animales de forma desinteresada, manteniendo mascotas. Este rasgo se manifiesta en diferentes épocas y culturas y no hace sino reflejar una actitud de observación hacia el comportamiento animal y de comparación de este con el humano. Los orígenes de la fábula de tipo esópico se encuentran probablemente en esta actitud. Las sociedades de la Antigüedad buscaron el conocimiento de la naturaleza humana en la observación del mundo animal. De ahí que un componente esencial de la fábula sea el didactismo, la enseñanza que se desprende de ella, que a veces es moral, pero siempre profundiza en las motivaciones del comportamiento humano. Sin embargo, aun siendo un género didáctico, la fábula ha sido desde sus orígenes un género plenamente literario, que se ha expresado con frecuencia en forma metrificada, lo que revela sus intereses artísticos. Aunque se encuentra entre los géneros literarios más antiguos y tuvo un amplísimo desarrollo en la Edad Media y en épocas posteriores de la literatura occidental, en el caso de la Literatura española ha recibido poca atención, pues generalmente se consideran sus producciones dentro del marco mayor del cuento.

El proyecto de investigación que dirijo, subvencionado por la Junta de Castilla y León "Adaptación y transformación de la fábula esópica en el Libro de buen amor" (LE20A10-1) se ha dedicado al estudio de las fábulas procedentes de la tradición literaria anterior, alteradas y reelaboradas en castellano en el siglo XIV por Juan Ruiz, Arcipreste de Hita, para hacerlas servir a nuevas intenciones ideológicas y artísticas. El trabajo realizado en este proyecto ha constituido un viaje personal de redescubrimiento de la importancia que un género habitualmente considerado menor ha tenido en la literatura española y en otras literaturas europeas desde su mítica creación atribuida a Esopo. Para comprender cuál había sido la labor del Arcipreste de Hita en sus adaptaciones esópicas fue necesario remontarse a la compleja transmisión textual de las fábulas a Occidente, compararlas con las versiones en lenguas romances anteriores a la que ofrece Juan Ruiz y percibir la necesidad de abordar el contexto cultural, literario y artístico, que las conectaba con el folclore, los bestiarios, la literatura proverbial o con las representaciones artísticas de animales. La persistencia de variantes de las fábulas esópicas que se incorporaron en el siglo XIV al Libro de buen amor en la literatura culta posterior y su pervivencia en la literatura oral de tipo tradicional muestra el vigor de un género creado, si hemos de creer las noticias más antiguas, hace más de dos milenios 
y medio. El hecho de que en una obra tan principal dentro de la literatura española hubiera todavía tantos aspectos por descubir y estudiar, hizo surgir la idea de celebrar un pequeño congreso que reuniera a investigadores de diferentes especialidades en torno al género fabulístico.

En la ilusión por la celebración de dicho congreso los miembros del equipo investigador del proyecto contamos con el apoyo de diferentes instituciones, entre las que cabe destacar la Universidad de León, la Sociedad Española de Estudios Clásicos, o el Instituto de Estudios Medievales.

Las páginas que a continuación se presentan abordan el género fabulístico desde distintas orientaciones a través de obras concretas o de su importancia e influencia en distintas literaturas y géneros literarios y constituyen una selección de las comunicaciones entregadas por los autores tras dicho congreso ${ }^{1}$.

León, 4 de abril de 2013

María Luzdivina Cuesta Torre

\section{MONOGRÁFICO EN EL PRÓXIMO NÚMERO}

El tema del próximo monográfico será: "Literatura, industria y medioambiente: estudios ecocríticos".

La selección de los artículos y su edición correrá a cargo de la Prof. Imelda Martín Junquera

\footnotetext{
${ }^{1}$ Los trabajos de coordinación y edición de este Monográfico forman parte de un proyecto de investigación subvencionado por la Junta de Castilla y León con referencia LE20A10. Las labores finales de corrección de pruebas se han realizado en el marco del proyecto de investigación subvencionado por el Ministerio de Economía y Competitividad del Gobierno de España (DGICyT) con referencia FFI201232265. Ambos proyectos, dirigidos por la Dra. Luzdivina Cuesta Torre, están dedicados al estudio de distintos aspectos de la fábula en la literatura española medieval. Las conferencias presentadas en el Congreso que versan sobre el Libro del Buen Amor se publicarán conjuntamente en el libro Adaptación y transformación de las fábulas esópicas en el "Libro de buen amor", coordinado por Luzdivina Cuesta Torre (en prensa).
} 


\title{
PRÁTICAS ESÓPICAS EM PORTUGUÊS (SÉCULOS XVII-XVIII)
}

\author{
TERESA ARAÚJO
}

Universidade Nova de Lisboa

\begin{abstract}
Resumo
Entre el inicio del siglo XVII y el ocaso del siguiente, pocas colecciones de fábulas en portugués salieron de las imprentas del reino. Sin embargo, observando este arco temporal, fácilmente se nota el interés de los letrados por la tradición esópica: el primer fabulario de Seiscientos alcanzó un número infrecuente de ediciones y el género fue constituyente de varias y distintas obras o a través de procedimientos alusivos o de recreaciones más o menos libres. Si su aplicación fue sobre todo argumentativa, en el campo de las letras ficcionales a veces logró más complexidad. Este estudio incide sobre algunos aspectos de la diversidad de las prácticas fabulísticas y profundiza la que articuló los esquemas retórico y poético.
\end{abstract}

Palavras chave: fábula esópica, Barroco, Portugal

\begin{abstract}
Between the beginning of the seventeenth century and the end of the eighteenth, very few fable collections in Portuguese were printed in Portugal. Nonetheless, during this period of time, one can notice the scholars' interest regarding the Aesopian tradition: the first seventeenth century fable collection had an unusual number of editions and the genre appeared in several other works either through allusion or free recreations. Although its application was mostly argumentative, when it comes to fiction the question is sometimes more complex. This study aims to identify some of the writing practices characteristic of fables and examines thoroughly the one that articulates rhetorical and poetic expression.
\end{abstract}

Key words: aesopian fable, Barroc, Portugal.

A ajuizar pelo panorama editorial das coleções esópicas em português, dir-se-ia que o interesse dos letrados dos séculos XVII e XVIII pela fábula foi diminuto no país. Com efeito, entre a publicação da Vida e Fabulas do Insigne Fabulador Grego Esopo (Mendes da Vidigueira, 1603) e a florescência de coletâneas ocurrida nos finais de Setecentos (Soares, 1785; Guerreiro, 1788; Creyo, 1796), não saiu dos prelos qualquer outro novo acervo. Pelo contrário, ao considerar-se o conjunto barroco (delimitado, no seu final tardio, pelo Terramoto de 1755) quer das formas alusivas e das atualizações menos

${ }^{1}$ Universidade Nova de Lisboa Correo-e: teresaraujo@fcsh.unl.pt. Recibido: 20-12-2012. Aceptado: 15-03-2013. O estudo foi preparado no âmbito do Projeto de Investigação apoiado pela Fundação para a Ciencia e Tecnología, A Fábula na Literatura Portuguesa. Catálogo e Historia Crítica (PTDC/CLELLI/100274/2008). 
concisas de temas fabulísticos interpoladas em contextos genológicos diferenciados, quer como o das composições elaboradas à maneira de Esopo ${ }^{2}$, a percepção é divergente. Constata-se a presença da fábula no universo das letras, sobretudo através dos seus efeitos ao nível da aplicação argumentativa e poética - a qual supõe a competência fabulística e hermenêutica dos escritores e do seu público. Todas estas expressões, embora indiretas, asseguram-nos o conhecimento arreigado do género.

As mostras da familiaridade remontam ao célebre manuscrito medieval, o Livro de Exopo (1994), elaborado no contexto da tradição esópica europeia, e a escritos impressos que se sucederam ao longo de Quinhentos, como o de Diogo Pires, redigido em latim e editado em Veneza, mas dedicado aos mestres e escolares de Lisboa, como sublinhou recentemente António Andrade (2007).

A singular compilação de Mendes da Vidigueira mostrou a continuidade do interesse e revitalizou-o, como se pode estimar pelo número incomum de reimpressões barrocas feitas em terra peninsular (1603/1611/1643/1648/1673/1705) - o qual apenas pode ser compreendido pela volumosa demanda dos letrados (e pelo natural benefício dos livreiros) que provinha da provável utilidade pedagógica da coleção e do apreço pela ficção inverosímil e edificante, defendida nomeadamente pelo Doutor da Corte na Aldeia (Lobo, 1992: 63). A divulgação fabulística alimentada pelo livro português deve ter sido acompanhada, como anteriormente, pela das impressões em latim, mas também pela das coleções espanholas que, a par de outras obras com igual proveniência, circulavam no país em virtude das condições políticas e culturais da época, particularmente do bilinguismo dos letrados portugueses. De facto, existem pelo menos nos arquivos da Biblioteca Nacional de Lisboa (BNP), da Biblioteca Geral da Universidade de Coimbra (BGUC) e da Biblioteca Central da Marinha (BCM), cinco fabulários antigos em espanhol nas seguintes edições: Libro del sabio e claríssimo fabulador Ysopo historiado e annotado (1533), pertença do Arcebispo de Évora, D. Teotónio de Bragança (1530-1602), e posteriormente do Convento de Santa Maria de Scala de Coeli (Évora), Ordem da Cartuxa, por doação do Arcebispo e fundador da casa (na BNP); nos fundos de Coimbra, La vida y fabulas del Esopo; a las quales se añadieron algunas muy graciosas de Aviano, y de otros sabios fabuladores (1607), que terá sido uma das fontes da peça dramática Esopaida ou Vida de Esopo de António José da Silva, segundo mostrou José Oliveira Barata (Barata, 1979: 56-86); no arquivo da BNP, Vida y exemplos del natural philosopho y formosissimo fabulador Esopo (1627) e Libro de la vida, y fábulas de el sabio, y clarissimo fabulador Isopo (1720); no da BCM, Fabulas y vida de Isopo con las de otros autores (1747).

Já o contributo do fabulário de La Fontaine não parece ter sido tão frutífero, como também alvitrou José Oliveira Barata no estudo da obra do Judeu, alegando o crítico que a influência da cultura francesa apenas suplantou plenamente a dos Siglos de Oro nas Luzes (1979: 59-60, 90-92). Na verdade, até então, o domínio do idioma

\footnotetext{
${ }^{2}$ Em breve, será disponibilizado o respectivo corpus, graças à investigação desenvolvida no âmbito do Projeto de Investigação apoiado pela Fundação para a Ciência e Tecnologia, A Fábula na Literatura Portuguesa. Catálogo e História Crítica apoiado pela Fundação para a Ciência e Tecnologia (PTDC/CLELLI/100274/2008). Entretanto, remeto para dois contributo recentes, o de Alexandra Madail (2003) e o de Luciano Pereira (2007).
} 
francês não era alargado, as primeiras traduções das fábulas do poeta de Thierry para português só começaram a ser realizadas pelos árcades e, em livro autónomo, apenas surgiram quando estava entrado o século XIX, Fábulas Escolhidas entre as de J. La Fontaine (Nascimento, 1813/1814/1815) e As Melhores Fábulas de La Fontaine (Semedo, 1820). Os reflexos franceses foram portanto tardios, posteriores ao período em análise, apesar de facilmente se admitir que o autor de algumas alusões fabulísticas, Raphael Bluteau, conheceu a obra de La Fontaine, pelo menos na época que esteve retirado em França, na transição de Seiscentos para o século seguinte. Em todo o caso, não terá sido a obra francesa a ditar as menções fabulísticas do teatino, dado o contexto da sua ocorrência, o Vocabulário Portuguez e Latino (Bluteau, 1712-1728) - cuja edição "prínceps" dos primeiros volumes comemora este ano o terceiro centenário. Bluteau, ao explicar os conceitos de "Familiaridade" e "Pretexto" no apartado "Vocabulario de Synonimos e Frases Portuguezas", evocou "o Apologo da vacca, da cabra, e da ovelha que andando à caça, se acompanharaõ com hum Leaõ" (Perry, 1965: 198, nº 5; 199, nº. 5) e o "Lobo da Fabula [que para] justificarse, atacou ao Cordeiro, que no lugar onde estava bebendo, turvava a agua" (Perry, 1065: 190, n. 1; 193, n. 1), respectivamente (Bluteau, 1728: 179 e 216). A concisão das alusões cala a sua proveniência e a lista de obras consultadas apresentada no dicionário também não oferece notícia relevante, mas é menos provável terem procedido da coleção francesa, mesmo das espanholas conservadas em Portugal (La vida y fabulas del Esopo, 1607: 88-89 e Vida y exemplos del natural philosopho y formosissimo fabulador Esopo, 1627: 17-19), do que da portuguesa (Mendes da Vidigueira, 1643: 17-18 e 9-10, respetivamente) ou inclusivamente do repertório transmitido oralmente - tal como muitos dos provérbios citados amiúde no dicionário.

Descontando a incerteza da sua progénie, as menções do erudito interpoladas em contexto lexicográfico corresponderam, no seu desenho breve e condensado, a um dos esquemas formais da prática fabulística, bem como a uma das modalidades semânticas da aplicação e a uma das molduras do recurso. Isto é, constituíram uma alusão que reproduziu o sentido do tema evocado num quadro demonstrativo. Mais complexas foram as que, a par de construções semelhantes à de Bluteau, emergiram no campo literário, nomeadamente as alusões ou as atualizações mais extensas do ponto de vista narrativo que reconfiguraram o significado da fábula prévia e agiram retórica e poeticamente. Estes casos de aplicação fabulística continuaram a revestir-se da moldura argumentativa da época medieval, em todo o caso já evidenciaram um ornato desenhado à luz da persuasão deleitosa que tinha paralelos do outro lado da fronteira (Martin García, 1996: 26-28). Embora não representassem o volte-de-face da fábula, da filosofia para a poesia, realizado pela reinvenção genológica de La Fontaine ainda desconhecida em Portugal, denotaram a crescente consideração das virtualidades poéticas da tradição esópica.

Observemos duas alusões interpoladas nas Cartas Familiares de D. Francisco Manuel de Melo (1981) que exemplificam os dois tipos de atualização semântica da fábula. A evocação do tema do lobo e do cordeiro, ao funcionar como preâmbulo da epístola sobre uma altercação política, não reconfigurou o sentido do texto prévio, 
comentado recentemente por Simone Regazzoni (2011), por se ajustar ao do novo contexto:

Digo-vos, que ha pazes, que nos estaõ muito mal, e muito peor quem as celebra; porque nunca vi amigo o cordeiro, e o lobo, que naõ fosse mal para o cordeiro (Melo, 1981: 81).

Já a menção à fábula do galo e da pérola (Perry: 1965, 278, nº. 12; 279, nº 12), ao ser aplicada na missiva que deprecia as afirmações de N. em relação ao autor, adotou forma paródica: "Mas isto he o mesmo, que o gallo com a pérola. Naõ me serve tal casta de honra" (Melo, 1981: 107). A alusão associou em imagem invertida as considerações de N. à pedra preciosa (sageza) e o autor da carta ao protagonista da fábula, que é invectivado no respectivo epimítio por ser incapaz de reconhecer a sabedoria e assim desaproveitar os seus frutos, como relembrou por exemplo Ana Paiva Morais (2005: 17-18). A inversão produziu, como se percebe, efeitos de ironia e sátira.

A fábula mencionada nesta carta não foi contemplada por Mendes da Vidigueira na sua coletânea, mas o tema teve larga tradição europeia desde a época medieval (Talavera, 2007: 70 e Morais, 2005: 17-18), repercutindo-se, por exemplo, na obra do Arcipreste de Hita (Ruiz, 2000: estrofes 1387-1389) e no Livro de Exopo (1994: 38-39). Em Seiscentos, foi integrado nas edições dos acervos em espanhol que se encontram depositadas nos fundos bibliográficos de Coimbra e Lisboa, La vida y fabulas del Esopo (1607: 87-88) e a Vida y exemplos del natural philosopho y formosissimo fabulador Esopo (1627: 16--17), bem como no Fabulario en que se contienen fábulas y cuentos diferentes (Mey, 1613: 14), que assumiu notoriedade. De onde terá provindo esta e a anterior alusão melodinas? O cabedal erudito do autor abre um grande leque de possibilidades, mas o facto de as ter aplicado no seu presídio na Torre de Belém, onde provavelmente não dispunha de livros que lhe recordassem as fábulas, faz admitir uma origem memorial comum à dos seus leitores. Em todo o caso, nenhuma das atualizações dos fabulários exprime o sentido da evocação de D. Francisco Manuel e, ainda assim, os leitores das Cartas Familiares compreenderam o significado alusivo, por disporem do tema no seu repertório memorial (de origem livresca ou outra) e de competências de leitura intertextual que lhes permitiam a hermenêutica da conexão.

Pelas mesmas razões, o público das Aves Illustradas alcançou o sentido da aplicação da mesma fábula, sob forma narrativa extensa, desenvolvida com a articulação de elementos fabulísticos e de materiais estranhos ao tema, em ordem ao programa retórico, mas também “deleitoso” da obra devocional de Maria do Céu (1734: 72-74).

É verdade que o rouxinol "illustrado" introduziu a narrativa esclarecendo a sua interlocutora sobre a matriz do seu relato, contudo também lhe fez notar a diferença do novo texto e não lhe indicou o respectivo tema: “ainda que pareça apologo de Esopo, he menos antigo" (Maria do Céu, 1734: 72). Detenhamo-nos por agora na advertência passareira, por ser apreciável do ponto de vista da reflexão meta-literária sobre a prática barroca da fábula. 
Em primeiro lugar, o aviso do rouxinol deixou transparecer a oscilação terminológica da época relativamente ao que hoje consideramos fábula. Aludiu à referência matricial do relato por "apologo de Esopo", enquanto outras vozes canoras do livro a designaram também por "fabula", "exemplo", entre outros termos com significado mais próximo ao de ficção.

Como observámos, também Bluteau a nomeou indiferenciadamente pelos dois vocábulos, apesar de ter tentado fixar, no mesmo dicionário, "apologo" como a designação de uma categoria de "fabula" estabelecida sobre a ideia de resistência à gentilidade primordial do género. Definiu-o como uma

[e]specie de fabula moral, em que se introduzem animaes, arvores, \& outras cousas inanimadas fallando, \& dizendo cousas de que se pode tirar alguma doutrina (Bluteau, 1712: 430),

exemplificando-o seguidamente com a narração de um episódio do Livro dos Juízes (9: 7-13) inserta no "Sermão Histórico Panegírico nos Anos da Rainha D. Maria Francisca deSaboia" do Padre António Vieira (Bluteau, 1712: 430). No volume seguinte, descreveu "fabula" como narrativa

inventada, \& composta de sucessos, que naõ saõ verdadeiros, nem verosimeis, mas com curiosa novidade admiraveis, como a transformaçaõ de Dafne em Loureyro, de Narcizo em flor, \&c. Naõ deixa a Fabula de ser proveitosa. Nas Fabulas de Esopo, \& de Phedro se encerraõ admiraveis documentos, \& bellas moralidades (Bluteau, 1713: 4),

apresentando posteriormente exemplos de relatos mitológicos e de obras intituladas por Apologo (Bluteau, 1713: 4-5).

A indistinção terminológica também se manifestou noutra obra devocional, a Nova Floresta do Padre Manuel Bernardes (1706-1728), pela mão da qual terminará este estudo, por conter exemplos da prática da fábula baseada na recriação narrativa dos temas sem a liberdade inventiva e poética do rouxinol das Aves Illustradas, mas com o recurso a elementos de outra fábula esópica. Antes disso, vejamos que na digressão sobre o conceito moral e religioso de "Alma", nomeadamente na demonstração do imperativo da presença dos clérigos nas comunidades de fiéis (almas) pelas quais eram responsáveis, Bernardes relatou o que constituiu a primeira atualização em português da fábula da cotovia e do lavrador (Perry, 1965: 108 e 110, nº 88, 109 e 111, nº 88). A sua narrativa foi introduzida como "o apologo, que se conta das cotovias que tinhaõ seus ninhos entre as searas" (Bernardes, 1706: 70-71) e concluída com outra denominação, "[a] moralidade desta fabula (que os Gregos chamaõ epimythion) està muy à flor da terra, mas explicallahei mais, naõ com palavras, mas com casos" (Bernardes, 1706: 71). Como se verifica, embora o autor tenha manifestado o conhecimento erudito do género ao denominar o constituinte final da fábula através da designação clássica, exprimiu a indiferenciação terminológica do rouxinol e de tantas figuras barrocas europeias.

O problema da nomenclatura já tinha uma avultada e complexa história profundamente relacionada com a génese e evolução do género, mas a fortuna do vocábulo "apólogo" advém sobretudo da refundição humanista do género fabulístico então considerado de segunda linha - note-se que, entre outros aspectos, era atribuído a dois escravos. A nova modalidade, como explicou por exemplo Consolación Baranda 
(2007), aproximou-se de modelos cultos de composição alegórica, introduzindo mais figuras mitológicas do que as narrativas esópicas, personificações de conceitos abstratos e articulando a narrativa com o esquema do diálogo literário. No entanto, não se afastou muito da tradição fabulística ao desenvolver programas de instrução moral. De modo que, segundo salientou Baranda, o apólogo não se repercutiu de forma muito acentuada na preceptiva epocal, senão nas obras de Alejo de Venegas e López Pinciano que divulgaram a dicotomia de Juan Luis Vives entre apólogo ou fábula esópica e fábula "milesia". A tratadística de Seiscentos, por seu lado, não distinguiu definitivamente o apólogo da antiga fábula, nomeadamente a teorização de Baltazar Gracián, cujo contributo ponderei noutro lugar ${ }^{3}$ e descreveu recentemente María Pilar Cuartero (2010), e tão pouco o fez o lexicógrafo Bluteau.

De maneira que a designação do rouxinol "illustrado" é exemplar desta indiferenciação terminológica com origens na refundição humanista da fábula e, em última instância - considerando a modalidade de atualização que ela introduz -, da recriação erudita iniciada pelos humanistas e praticada também, embora com as devidas distâncias, por D. Francisco Manuel de Melo, em meados do século XVII, sob o título Apólogos Dialogais (1998).

Por outro lado, a advertência do rouxinol é também estimável por definir a narrativa imediata através dos critérios de semelhança e diferença relativamente à matéria prévia e por, deste modo, também estabelecer o protocolo hermenêutico do novo texto.

O relato da ave, interpolado no "Discurso" protagonizado pela figura canora um procedimento de atualização da fábula na fábula desenvolvido por outros textos, como mostrarei noutro lugar -, conta o seguinte: um galo, tendo encontrado uma pérola, um objecto de vidro e uma pedra de sal e não vendo a utilidade que podia retirar dos achados bem distintos do desejado grão de cereal, procurou o conselho de uma águia para decidir a distribuição do pecúlio. Recomendou-lhe "Sua Magestade Aquilina" que entregasse o segundo "á dama", para que a matéria do objecto a advertisse da precariedade da sua existência, o terceiro "ao homem" com o intuito de o exortar à salvação e a pérola a si mesma, "que a quero enfiar em hum rayo de Apollo, porque a tudo o mais precioso tem direito os deoses" (Maria do Céu, 1734: 73). O animal doméstico contestou a decisão da oferta a Apolo, mas perante a explicação imediata do imponente pássaro, "[r]epartio o gallo o seu achado conforme a sentença da aguia, que a muytos pode deyxar ilustrados, e a todos advertidos" (Maria do Céu, 1734: 74).

Confrontemos a narrativa com as referências fabulísticas citadas a propósito da alusão melodina ao mesmo tema - voltando a não agregar o Libro de la vida, y fabulas de el sábio, y clarissimo fabulador Isopo, em virtude do exemplar da Biblioteca Nacional de Lisboa corresponder a uma edição (1720) quase coincidente com o falecimento da autora (1723).

3 "Fábula e Política na Restauração", Dedalus. Revista da Associação Portuguesa de Literatura Comparada, 16 (no prelo). 
O relato canoro aumentou o pecúlio encontrado pelo galo da fábula, a fim de fazer refletir na moralidade os "tópoi" da fragilidade humana e da salvação pela palavra bíblica, aludida pela metáfora do sal que se lê nos Evangelhos de Marcos $(9,50)$, Mateus $(5,13-14)$ e Lucas $(14,34$ e seguintes). Também introduziu um novo protagonista cristianizado, embora "ilustrado" pela sabedoria do seu deus Sol e devoto de Apolo, para reconfigurar o percurso narrativo do galo da fábula em ordem à sua metamorfose cristã. Com efeito, a ave de capoeira irrompeu na narrativa do rouxinol tão insensata quanto a esópica, ainda que a imprudência do galo de El Libro de Buen Amor (Ruiz: estrofes 1387-1398) e do Livro de Exopo (1994: 38-39) apresente moldura ético-filosófica, o de La vida y fabulas de Esopo (1607: 87-88) e de Vida y exemplos del natural philosopho y formosissimo fabulador Esopo (1627: 16-17), uma configuração literária (de acordo com a tradição clássica), o do Fabulario en que se contienen fabulas y cuentos diferentes (Mey, 1613: 14), um carácter moral e o de Sóror Maria do Céu, um contorno religioso. No entanto, o galo das Aves Illustradas, ao contrário de todos os outros, acabou regenerado e prudente (cristianizado) mediante a lição da águia sobre a transcendência dos achados, especialmente a do mais valioso. Na explanação da moralidade da sua fábula, o rouxinol amplificou ainda a dimensão simbólica do valor da pérola esópica, porquanto lhe atribuiu não só valia espiritual, como material, para deste modo a fazer representar a ideia de totalidade.

Como se observa, a recreação fabulística foi imposta pela finalidade de exortação piedosa e aplicada segundo o esquema retórico da exemplificação e demonstração, no entanto também se percebe na recomposição um programa de persuasão deleitosa e a noção das potencialidades poéticas do género.

Tinha razão o pássaro narrador ao advertir para a novidade do seu relato, mas existiram outras práticas contemporâneas à sua que, embora sem esta liberdade poética, constituíram-se a partir de um procedimento igualmente criativo - e bastante revelador da familiaridade da tradição esópica no mundo das letras -, a conjugação de diferentes fábulas. Observemo-lo, para concluir, em dois relatos com igual composição temática aplicados retoricamente na Nova Floresta, nas suas digressões sobre as astúcias da linguagem para dissimular a falta de razão e sobre a perversidade da imputação de culpa aos inocentes (Bernardes, 1708: 270 e 1726: 431-432, respectivamente). Iniciam assim:

Podemos exemplificalo cõ o apologo do que succedeo ao cordeyrinho com o lobo. Dizem que tinhaõ estes feito tregoas por certo tempo; \& antes de se acabar se encontraraõ ambos bebendo em hum regato. Desejava o lobo quebrar as tregoas, e comer o cordeyro e para achar occasiaõ de briga, disselhe muy sanhudo: Para que me turbais a agoa que estou bebendo? (Bernardes, 1708: 270).

Naõ deixarey de contar um apologo engraçado, que a este proposito traz o Padre [Jeremias] Drexelio. No tempo em que o lobo, e o cordeiro estavaõ em treguas, desejava aquelle, que se oferecesse ocasiaõ, para as romper. E hum dia, que ambos se acharaõ nas margens de hum regato indo beber, disse o lobo muy encolerizado para o cordeiro: Porque me turbais a agua que vou beber? (Bernardes, 1726: 431). 
As duas narrativas terminam de acordo com o desfecho do tema do lobo e do cordeiro, mas ambas começam com a presença da fábula do lobo e das ovelhas (Perry, 1965: 114, n. 93, 115, n 93), nomeadamente com o seu motivo das tréguas entre os protagonistas, aqui adaptado ao novo contexto sob o do armistício intencionalmente interrompido pelo lobo - do qual resultou extremado o contraste entre a abertura e o final da fábula preponderante do texto de Bernardes, bem como a respectiva perfídia lupina.

O autor indicou a proveniência do seu relato, mas lendo o Orbis Phaëthon, verificase que o jesuíta alemão, ao expor o sentido de calúnia, aplicou apenas a fábula do lobo e do cordeiro (denominada pelo vocábulo também usado pelos letrados peninsulares) a partir do texto clássico: "[a]ppositum huic rei apologum recitans Phædrus" (Drexelio, 1629: 24-25). A recriação composta pelos dois temas foi portanto da lavra de Bernardes, que podia conhecer o do lobo e da ovelhas através das coleções seiscentistas espanholas (La vida y fabulas del Esopo, 1607: 65-66, entre outras) ou de uma memória livresca ou imaterial mais antiga, se considerarmos a fórmula de abertura do primeiro relato "[d] izem que". Com efeito, o Livro de Exopo dá testemunho nas suas narrativas de uma chave semelhante "[c]omte-sse que" e inclusivamente inclui a dita fábula (1994: 73-74).

Intensificado deste modo criativo o significado dos temas prévios, nenhum dos dois relatos da Nova Floresta introduziu outro aspecto re-configurador digno de nota, resultando a moldura ético-religiosa da sua aplicação do contexto da obra, esse semelhante ao do Orbis Phaëthon.

\section{BIBLIOGRAFIA}

Andrade, António Manuel Lopes (2007): “A Fábula na Obra Poética de Diogo Pires”, Ágora. Estudos Clássicos em Debate, 9: 99-118.

Baranda, Consolación (2007): “El apólogo y el estatuto de la ficción en el Renacimiento", Studia aurea. Revista de Literatura Española y Teoría Literaria del Renacimiento y Siglo de Oro, 1, www.studiaaurea.com/articulo.php?id=45 (Consultado em novembro de 2012).

Barata, José Oliveira (1979): "Introdução" in António José da Silva, Esopaida ou Vida de Esopo, edição sinóptica e interpretativa, leitura do manuscrito, introdução, notas e comentários de José Oliveira Barata, Coimbra, Por Ordem da Universidade: 7-93.

Bernardes, Padre Manuel (1706-1728): Nova Floresta, ou Sylva de Varios Aphothegmas e Ditos Sentenciosos, Espirituaes e Moraes... com o Vario da Erudiçaõ, assim Divina como Humana, Tomos I e II, Lisboa, Na Officina de Valentim da Costa Deslandes, 1706-1708; Tomos III, Lisboa, Na Officina Deslandiana, 1711; Tomos IV e V, Lisboa Occidental, Na Officina de Joseph Antonio da Silva, 1726-1728.

Bluteau, Raphael (1712-1728): Vocabulario Portuguez e Latino, I-IV, Coimbra, Colégio das Artes, 1712-1713; V-VIII, Lisboa, Pascoal da Sylva, 1716-1721; Suplemento ao Vocabulario Portuguez e Latino, I, Lisboa, Joseph Antonio da Sylva, 1727; II, Patriarcal Officina da Musica, 1728. 
Creyo, Romão Francisco António (1796): Fabulas Litterarias de Thomas Yriarte traduzidas do castelhano por Romão Francisco Antonio Creyo, Porto, Off. de Viuva Mallen, Filhos e Comp.

Cuartero Sancho, María Pilar (2010): “La fábula en Gracián”, Biblioteca Virtual Universal, www.biblioteca.org.ar/libros/155232.pdf (consultado em novembro de 2012).

Drexelio, Hieremia (1629): Orbis Phaëthon, hoc est de vniuersis vitiis linguae pars altera, Monachii.

Fabulas y vida de Isopo con las de otros autores traduzidas por Juan de Lama (1747): Madrid, Alonso Padilla.

Guerreiro, Miguel do Couto (1788): Fábulas de Esopo reduzidas a rima com aplicações acomodadas à moral cristã. oferecidas ao exmo. Senhor D. José de Assis Mascarenhas, Lisboa, Officina Patriarcal de Francisco Luiz Ameno.

La vida y fabulas del Esopo a las quales se añadieron algunas muy graciosas de Aviano, y de otros sabios fabuladores (1607): en la oficina Plantiniana.

Libro de la vida, y fábulas de el sábio, y claríssimo fabulador Isopo (1644/1657/1677/1720/1728/1813 ): Madrid, Gregorio Rodriguez, a costa de Iuan de Valdes; Madrid, en la Imprenta Real, a costa de Antonio Rodriguez del Ribero; Valencia : por Lorenço de Cabrera; Valencia, por Lorenço de Cabrera; Madrid, imp. de Angel Pascual; Madrid, Pedro Joseph Alonso de Padilla; Segóvia/Madrid, En la imprenta de Espinosa/en la del mismo.

Libro del sabio e claríssimo fabulador Ysopo historiado e annotado (1533): Sevilla, por Juan Cromberger. Livro de Exopo (1994): edição crítica com introdução e notas de Adelino de Almeida Calado, Coimbra, Separata do Boletim Bibliográfico da Universidade de Coimbra, 42.

Lobo, Francisco Rodrigues (1992): Corte na Aldeia, introdução, notas e fixação do texto de José Adriano de Carvalho, Lisboa, Presença.

Madail, Alexandra Maria de Melo (2003): Recepção Literária de Esopo e Fedro em Autores Portugueses [Dissertação de Mestrado], Aveiro, Universidade de Aveiro.

Maria do Céu, Sóror (1734): Aves Illustradas em Avisos para as Religiosas Servirem os Officios dos seus Mosteiros, Lisboa, Officina Miguel Rodrigues.

Martin García, Francisco (1996): “Introducción” in Antología de fábulas esópicas en los autores castellanos (hasta el siglo XVIII), Cuenca, Universidad de Castilla-La Mancha: 9-39.

Melo, D. Francisco Manuel de (1981): Cartas Familiares, prefácio e notas de Maria da Conceição Morais Sarmento, Lisboa, Imprensa Nacional-Casa da Moeda.

Melo, D. (1998): Apólogos Dialogais, edição e introdução de Pedro Serra, I. Os Relógios Falantes. A Visita das Fontes, II. O Escritório Avarento. O Hospital das Letras, Braga, Angelus Novus.

Mendes da Vidigueira, Manuel (1603/1611/1643/1648/1673/1705): Vida e Fábulas do Insigne Fabulador Grego Esopo, Evora, Manuel de Lyra; Lisboa, Jorge Rodrigues; Lisboa, Antonio Alvarez; Lisboa, Francisco Villela; Lisboa, Francisco Villela; Coimbra, José Antunes da Silva, Impressor da Universidade.

Mey, Sebastian (1975): Fabulario en que se contienen fábulas y cuentos diferentes, algunos nuevos y parte sacados de otros autores, edición e introducción de C. BravoVillasante, Madrid, Fundación Universitaria Española. 
Nascimento, Francisco Manuel do [Filinto Elísio] (1813/1814/1815): Fábulas escolhidas entre as de J. La Fontaine, Londres, Typographia de H. Bryer; Lisboa, Imprensa Regia; Paris, na Officina de Cellot.

Paiva Morais, Ana (2005): “Histórias do Ínfimo”, Forma Breve, 3, A Fábula: 11-20.

Pereira, Luciano José dos Santos Baptista (2007): A Fábula em Portugal: Contributos para a História e Caracterização da Fábula Literária, Porto, Profedições.

Perry, B. E. (1965): Babrius and Phaedrus Fables, Cambridge/Massachusetts-London, Harvard University Press/Loeb Classical Library.

Regazzoni, Simone (2011): “Du Loup. Force et Loi”, Escritura e imagen, vol. ext.: 259-270.

Ruiz, Juan, Arcipreste de Hita (2000): El Libro de Buen Amor, Alicante, Biblioteca Virtual Miguel de Cervantes, www.cervantesvirtual.com/obra/el-libro-de-buen-amor (Consultado em novembro de 2012).

Semedo, Curvo [Belmiro Transtagano] (1820): As Melhores Fábulas de La Fontaine, Lisboa, Impressão Regia.

Soares, Manuel de Morais (1785): Fábulas de Fedro, Escravo Forro de Augusto César, Lisboa, Officina Patriarcal de Francisco Luiz Ameno.

Talavera Cuesta, Santiago (2007): “Estudio general de las fábulas" in La fábula esópica en España en el siglo XVIII, Cuenca, Universidad de Castilla-La Mancha: 67-185.

Vida y exemplos del natural philosopho y formosissimo fabulador Esopo (1627): Salamanca, Em casa de Antonia Ramirez. 


\title{
DE GRECIA A NARNIA: LA FÁBULA DEL LEÓN Y EL RATÓN FUERA DE LAS COLECCIONES DE FÁBULAS
}

ANA MARÍA MARIÑO ARIAS

Universidad de León ${ }^{1}$

\section{Resumen}

Las fábulas, además de transmitirse a través de colecciones revisadas y rehechas una y otra vez a lo largo de la historia por diferentes autores, se han incorporado como parte del argumento en otros géneros y tradiciones, con algunos cambios pero conservando su argumento principal. En el presente artículo se estudia de que modo se ha hecho en el caso concreto de la fábula esópica del león y el ratón en tres obras: un cuento anónimo del Antiguo Egipto, el Libro del Buen Amor y Las Crónicas de Narnia.
\end{abstract}

Palabras clave: fábula, león, ratón, Esopo, Egipto, cuento, Libro del Buen Amor, Narnia

\begin{abstract}
Fables have been transmitted through history in thousand times cheked and remade collections by different authors. Besides, they have been attached to the topics of other genres and literary traditions with a few changes but preserving their main story line. This article studies the presence of the esopic fable of the lion and the mouse in three different works: an anonymous tale from the Ancient Egypt, El Libro del Buen Amor and Narnia Chronicles.
\end{abstract}

Key Words: fable, lion, mouse, Esopo, Egypt, tale, Libro del Buen Amor, Narnia

La fábula es un género muy relacionado con la tradición oral y la literatura popular cuya esencia es la brevedad y la intención moral. Además de su condición de género hipertextual, ya que al ser un género menor y un tipo de literatura popular, su tradición textual está abierta, desde la Antigüedad se han traducido, interpretado y recreado las mismas fábulas. Sin embargo, con la tradición va unida la variación, aunque más en la forma que en el tono, pues el armazón lógico y argumental de la fábula es muy rígido.

Antonio Cascón Dorado (1987-88: 74) pone de manifiesto que se producen similares fenómenos de transmisión en la fábula y el exemplum: cambio de personajes, de situaciones argumentales, ampliaciones, abreviaciones, duplicaciones,

${ }^{1}$ Correo-e: khendra@hotmail.es. Recibido: 19-12-2012. Aceptado: 15-03-2013. 
contaminaciones, cambios de intencionalidad..., fenómenos que se aprecian fácilmente al realizar comparaciones entre distintas versiones de la misma fábula.

Pero, además de las modificaciones que se aprecian al comparar las diversas colecciones de fábulas, las fábulas también pueden integrarse como parte del argumento en obras de otros géneros literarios, alterando igualmente algunos de sus elementos en función de las necesidades o intenciones del autor, pero conservando claramente su esencia.

Así pues, a continuación, estudiaremos la forma en que ha sido adaptada una fábula esópica, la fábula del león y el ratón, en tres obras de mayor extensión, de géneros diferentes y de momentos y lugares muy dispares: un cuento egipcio anónimo, el Libro del Buen Amor del Arcipreste de Hita y Las Crónicas de Narnia de C.S. Lewis.

A Esopo no le consideraban los griegos como el inventor del género, sino el introductor en Grecia de la primera colección de fábulas, que fijó el tipo clásico de tales relatos: breves y didácticos, con una estructura narrativa característica. Sobre él se tejió desde muy antiguo una leyenda biográfica, núcleo de la Vida de Esopo, cuya ideología coincide con la que se desprende de la colección de fábulas: Esopo se vale de la astucia para triunfar en un mundo donde imperan la fuerza, el engaño y la lucha constante de unos contra otros, sin más sanción moral que el éxito o el fracaso.

La fábula del león y el ratón en la redacción atribuida a Esopo (H.155) consiste en una sencilla anécdota: un ratón juega con otros hasta que despierta a un león y éste lo coge para a comérselo. El ratón le pide que lo suelte, prometiendo que le pagará el favor y felino accede aunque sin tomarse en serio el ofrecimiento. Un día es apresado por unos cazadores, atado a un árbol y liberado por el ratón que roe la cuerda. Por último se cierra con un parlamento del ratón expresando que también los pequeños tienen gratitud.

El tema fundamental que ilustra esta fábula es el del animal agradecido, desarrollado para poner de manifiesto el desagradecimiento de los hombres. Tema que se repite en otras fábulas empleando otros animales, así como la liberación de elefantes y gacelas por ratones aparecen en fábulas de la India, que pueden ser independientes o derivadas de las griegas. (Rodríguez Adrados, 1987:165)

La egiptóloga Emma Brunner-Traut (2000: 334) considera que esta fábula griega tiene como modelo un cuento egipcio que desarrolla de manera mucho más extensa la trama. Se basa, entre otras cosas, en que en la Vida de Esopo, se sitúa al griego recopilando materiales para sus fábulas en las orillas del Nilo. Sin embargo, Rodríguez Adrados (1987: 725) piensa, por el contrario, que el modelo es la fábula griega, considerando que es ésta la que tiene un origen antiguo mesopotámico, por la estructura de la fábula griega que es perfectamente regular y posiblemente arcaica, dada su organización en dos actos y que en el Pañcatantra existe un paralelo casi exacto, sustituyendo el león por un elefante. Además de que el tema del animal agradecido se encuentra varias veces en tanto en fábulas griegas como indias. 
Este cuento egipcio (Brunner-Traut, 2000: 181) fue redactado en época helenística y transcrito en el siglo II d.C. en caracteres demóticos. En él, un poderoso y aterrador león va recorriendo el desierto buscando al hombre para castigarle por las tropelías que ha hecho a los diversos animales que se va encontrando: una pantera, un caballo y un asno, un toro y una vaca, un oso e incluso a otro león. En su periplo está a punto de pisotear a un ratoncillo que le ofrece salvarle de la desgracia, cosa que el prepotente león se toma a broma pero que, al igual que en la fábula esópica, termina siendo lo que ocurre cuando el felino cae en la red del cazador. Finalmente ambos se marchan juntos de vuelta al desierto.

En la versión de Esopo el ratón se disculpa por su ignorancia al haber molestado al león y es el león el que considera que es indigno de él vengarse de un ser tan pequeño. Sin embargo, en el cuento egipcio, el roedor suplica alegando que si se lo come no saciará su hambre y prometiéndole, casi vaticinándole, que si le perdona la vida algún día podrá devolverle el favor, algo que causa la hilaridad del felino, aunque acaba soltándolo igualmente, pensando que no le iba a llenar el comérselo. La acción y promesa de Esopo se convierten en destino y premonición al imbricarse en un contexto religioso: una conversación en la que el mono mensajero Thot entretiene y aconseja a la diosa leona Tefnut, la gata del sol, durante su peregrinación.

Por tanto, en el caso del cuento egipcio el tema, más que en el agradecimiento en sí, se centra en resaltar la valía de lo que a simple vista parece insignificante: el poderoso y arrogante león, que se dispone a vengar al resto de los animales atropellados por la crueldad del hombre, acaba cayendo en una de las trampas de éste y siendo salvado por un minúsculo ratoncito del que se burló. Así como que, cuando el destino así lo determina, los más débiles pueden ayudar a los más fuertes, algo muy importante en el contexto en el que se enmarca.

Existe otro cuento de Kordofán, al oeste del Alto Nilo, zona de influencia de la tierra de los faraones, derivado del anterior, conservado oralmente y recopilado en el siglo XX por L. Frobenius (Brunner-Traut, 2000: 184). Aquí es el ratón el que provoca al león, resaltando que la inteligencia es preferible a la fuerza y le reta a enfrentarse al hombre, que resulta ser un comerciante de madera que pasaba por allí. El leñador finge aceptar el reto y consigue que el león se deje atar a un árbol, cosa que aprovecha para golpearle con una cuerda. Cuando finalmente el hombre se marcha, el ratón accede a desatar al león tras lograr que le prometa amistad eterna. El león intenta vengarse pero termina escaldado, literalmente, y cuando vuelve a ver al ratón intenta comérselo culpándolo de la situación en la que se haya pero el roedor logra zafarse de la presa con astucia. Tiempo después y tras varias tretas más, el leñador termina consiguiendo que ese león y toda una manada de leones le jure estar a su servicio.

A pesar de la independencia de la trama, los elementos esenciales idénticos llevan a la conclusión de que no han podido ser creados de forma independiente. El distinto ambiente cultural y el diferente estado de ánimo explican el aumento de la crueldad y el sentido final del cuento, explicar la relación entre los faraones y los leones, no solo 
símbolo de soberanía, también acompañantes y protectores en la guerra. (BrunnerTraut, 2000:335)

En ambos casos se mantienen varios elementos de la fábula original: los protagonistas, el león y el ratón, si bien en los cuentos se incluye la presencia humana, y también el tema de la crueldad, ausentes en el texto griego. El cuento egipcio no incluye el apresamiento del roedor sino que el felino casi lo pisa pero en el de Kordofán sí ocurre, así como el hecho de que el punto inicial de la trama sea que el ratón molesta al león, aunque de distinta forma. Sin embargo, a diferencia de la fábula, esa prisión del ratón sucede después de la liberación de las cuerdas del león por el ratón y rompiendo el felino así, su promesa de amistad eterna al roedor. Además, éste se libra de las garras no con promesas sino con ayuda de su ingenio y aprovechando el miedo que en ese momento le tiene el león al hombre.

La recepción medieval de la obra de Esopo fue trazada hace más de un siglo por Hervieux (1970) en su extenso estudio acerca de los fabulistas latinos, desde la época de Augusto hasta finales de la Edad Media. Se produce bien por medio de Fedro, en latín, sobre todo a través de la versión en prosa latina del Romulus, bien mediante la obra de Babrio, en griego, y especialmente mediante la versión en dísticos elegiacos latinos de Aviano. Ello determina la existencia en este periodo de dos líneas de transmisión de las fábulas esópicas, a las que los distintos recopiladores irán añadiendo otras de distintas procedencias, haciendo que, de ciento cincuenta, pasen a ser más de doscientas fábulas.

En esta época, Esopo pertenecía al grado inferior de los "auctores minores", empleado para la enseñanza de la gramática y de la retórica, dado que sus fábulas, gracias a su brevedad, sencillez y fácil moralización, eran un adecuado material didáctico. Con esta orientación surge el "Esopo moralizado", una versión latina versificada en la que se cristianizan las fábulas y se adaptan al uso escolar medieval. Se atribuye al poeta Walter el Inglés o Gualterius Ánglicus, del siglo XII, que se sirvió del Romulus vulgaris (o Recensio gallicana, del siglo V o VI), el más difundido de los Romuli en prosa. El supuesto autor, Romulo, no conoció la obra de Esopo, sino la tradición latina de Fedro, cuyas fábulas parafrasea y reorganiza, a la que añade otros materiales y nuevas fábulas creadas a partir de la imitación del estilo de Fedro. Estas fábulas de Gualterius Ánglicus, como obra de lectura obligatoria en la clase del grammaticus, se difundieron en la Edad Media por medio de comentarios que acompañaron a los dísticos originales desde finales del siglo XIII.

El Arcipreste de Hita se basó mayoritariamente en esta obra, aunque en algunos casos parece alejarse de ella por manejar un manuscrito con glosas interlineales y extensos comentarios, en las fábulas que pone en boca de las protagonistas principales en el episodio de doña Garoza en el Libro del Buen Amor, como ha estudiado Bienvenido Morros (2003). A lo largo de dos días la alcahueta Trotaconventos y la monja amada por el arcipreste, intercambian diez fábulas que sirven para ilustrar sus opiniones contrapuestas, si bien no siempre se establece claramente la relación entre el contenido de las fábulas y la situación a la que pretenden aplicarlas. Es bastante probable que esto se deba a que el autor otorga más importancia a las interpretaciones morales de 
los comentaristas de los hexámetros de Gualterio que a la literalidad de lo expuesto por la fábula (Morros, 2003: 431).

En el presente caso, la fábula del león y el ratón, Juan Ruiz se ciñe bastante al texto de Ánglico y sólo recurre a las glosas interlineales cuando el texto no es suficientemente claro (Morros, 2003: 417).

No obstante, el papel del protagonista, aunque continúa siendo positivo, no lo es tanto como en la versión de Gualterio. Esto responde a que la fábula está narrada por Trotaconventos, que se identifica con el ratón mientras atribuye a doña Garoza el papel del león, de ahí que sea el primero el que muestra mayor ingenio y capacidad discursiva, como ha señalado Luzdivina Cuesta (2010: 483).

Así pues, nos encontramos con una versión de esta fábula en el Enxiemplo del león e del mur (1425-1436) puesto en boca de la alcahueta en el momento en que sus anteriores propuestas, también expresadas a través de fábulas, han despertado la ira de la monja. El miedo a la mal velada amenaza inspira ala vieja a aprovechar y reforzar, con los elocuentes argumentos del ratón, la enseñanza moral del escaso honor que supone para el grande el hecho de vencer al pequeño, presente especialmente en la interpretación de Gualterio de la fábula del león y el ratón.

Además el comentarista de Ánglico identificaba al león con el rico y al ratón con el pobre y especificaba que el pobre puede resultar de gran utilidad en el aspecto religioso al rico, conociendo el trato que los evangelios otorgan al menesteroso. De este modo, Trotaconventos pretende, al identificarse con el ratón, dar cuenta de su utilidad en cualquier circunstancia, ofreciendo, a cambio de poder y riqueza, su entendimiento y astucia. Sin embargo, se mantiene la ambigüedad de toda la obra, por lo que se abstiene de aclarar con qué propósito, si para afianzar y consolidar su amor por Dios o si, por el contrario, pretende invitarla a valerse de su astucia e inteligencia para eludir el castigo de incurrir en el pecado del loco amor (Morros, 2003: 439).

Cuando Clive Staples Lewis, profesor de Lengua y Literatura Inglesas en la prestigiosa Universidad de Oxford, publicó en 1950 El león, la bruja y el armario, la primera de siete novelas de Las Crónicas de Narnia (1950-1956), era un autor académico de gran relieve por sus estudios eruditos de Literatura Renacentista Inglesa y sus reflexiones sobre la condición humana².

Su amplia formación académica, unida a su pasión por la lectura desde la infancia, hace que, en ocasiones, en su obra aparezca una amalgama de elementos e influencias dispares, hasta el punto que su amigo, colega y también creador de obras de fantasía, J.R.R. Tolkien, no comprendía cómo Lewis había podido escribir algo tan poco coherente y menos aún, cómo a pesar de ello había triunfado.(Carpenter,

\footnotetext{
${ }^{2}$ Lewis fue profesor de literatura inglesa medieval y renacentista prácticamente toda su vida. Fue fellow en el Magdalen College y miembro del consejo de Gobierno de la Universidad de Oxford entre 1925 y 1954 (29 años) y en 1954 fue nombrado profesor en la Universidad de Cambridge, en la cual enseñó hasta su muerte en 1963 (9 años). Es decir, dedicó 38 años a la academia, de los 65 que el escritor pasó por este mundo.
} 
2008:357) Y esto, teniendo en cuenta que el germen de Narnia fue el resultado de echar a suertes la decisión de quien de ellos escribiría una novela basada en un viaje espacial (Lewis) y quien en uno temporal (Tolkien). (Carpenter, 1993:516, 567)

Narnia es un mundo imaginario, poblado por personajes de muy distintas fuentes, creado en El sobrino del mago (1955) por el único personaje que aparece en toda la saga, Aslan, un gran león, cosa que no resulta nada sorprendente dado que su nombre es la traducción de león en turco.

La elección de un león como personaje fundamental puede atribuirse a múltiples motivos e influencias, desde la astrología, el mundo clásico, el culto de Mitra, la heráldica... Pero en este caso, es más que evidente la conexión de la imagen del león conla figura de Cristo, al igual que en los Bestiarios medievales y en una larga tradición literaria y teológica. En palabras del propio autor en una carta: "Le di forma de león porque se supone que el león es el rey de las bestias, y Cristo es el León de Judá mencionado en la Biblia." ${ }^{3}$

No obstante, también podemos rastrear una clara influencia de la fábula esópica, que probablemente leyó en su infancia, fascinado como estaba con las historias cuyos protagonistas eran animales, como las de Beatrix Potter. (Carpenter, 2008, 21) En concreto, en El león, la bruja y el armario encontramos rastros de dos fábulas esópicas más, aparte de la del león y el ratón, en las que los leones son la clave.

En primer lugar, la del león como rey de las bestias (H. 179). Se trata de un reinado idílico en el que los fuertes dan cuenta de sus actos a los débiles y todos los animales son felices. En Narnia lo vemos reflejado en la profecía del castor:

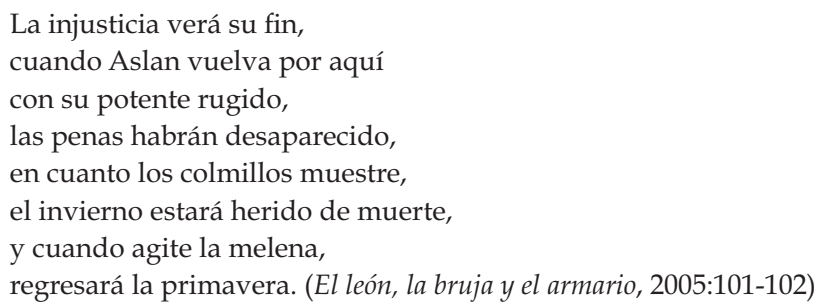

También se aprecia con claridad, el rastro de la fábula del león viejo y débil (H. 201) que ha de soportar el escarnio y las injurias de los otros animales, ahora que ya no es temido hasta que la frustración le lleva a clavarse sus propias garras en el pecho para matarse. En este caso, y siguiendo la línea de la alegoría cristológica, Aslan se entrega voluntario como víctima sacrificial para salvar a uno de los niños protagonistas. Esto propicia que, aprovechando su debilidad al permitir que le aten, las malévolas y bajas criaturas pierden el temor y le golpean y afeitan antes de matarlo clavándole un cuchillo de piedra en el corazón, dado que la salida del suicidio sería impensable en el contexto cristiano en el que nos movemos.(El león, la bruja y el armario, 2005:189-193)

\footnotetext{
${ }^{3}$ Una carta inédita del autor de estos libros revela la evidencia clara y contundente del mensaje que él quiso plasmar en Las Crónicas de Narnia. Esta carta, con fecha del año 1961, fue enviada por C. S. Lewis a un niño que leía sus historias y ha sido divulgada por Walter Hooper, quien fue secretario de Lewis y se convirtió en su biógrafo.
} 
Incluso en el último volumen de la saga, La última batalla (1956), el conflicto se articula en torno a la fábula del asno vestido con la piel de león y los problemas y confusiones que provoca al hacerse pasar por Aslan.

Pero, volviendo a la fábula que nos ocupa, la del león y el ratón, su presencia en la trama es evidente, si bien modificada y adaptada a las necesidades del relato en el que se inserta.

Tras el sacrificio del león en la Mesa de Piedra, los asesinos se marchan dejando el cadáver atado y es en ese momento cuando aparecen cientos de minúsculas formas grises que resultan ser ratones que llegan para roer las cuerdas que aprisionan al gran felino.

Es llamativo el hecho de que la primera reacción de una de las dos niñas protagonistas de la obra, que están llorando la muerte del león, sea la de rechazar a los roedores y apartarlos del cadáver de su amigo. Emplea además los adjetivos "asquerosos", "horribles" y "mugrientos" antes de intentar apartarlos. Finalmente, al percatarse, gracias a su hermana, de la actividad a la que estaban entregados, les permiten continuar, si bien mencionan la inutilidad de tal acción.

De este modo, se ha suprimido la primera parte del argumento original: la del ratón preso que recibe la merced del perdón del león. El hecho de no existir la deuda de vida que origina la salvación del león de la red que lo aprisiona, permite la aparición de un nuevo componente ausente en las versiones anteriores: la gratitud del león, posible gracias a la resurrección del gran felino al amanecer y que, además, contribuye a aumentar los rasgos positivos de la figura del león, muy adecuado dado que representa al Mesías cristiano.

El príncipe Caspian (1951), la siguiente novela publicada, incorpora unos peculiares personajes: doce ratones que ayudan a pelear al protagonista, el príncipe Caspian contra el usurpador Miraz, su tío. Son más grandes de lo habitual, tienen largas orejas y portan espadas con aire marcial, de modo que, al conocerlos, Caspian tuvo que esforzarse para no reírse de su ofrecimiento de ayuda y tampoco se les permite ser jueces en el duelo entre Miraz y el rey Peter. Sin embargo, durante la batalla desempeñan un papel fundamental: clavan sus estoques en los pies de los enemigos, haciendo que caigan y estorbándoles.

A pesar de su valor, Reepicheep, su líder, resulta muy mal herido y aunque logran curarle, pierde su cola en la batalla. Un hecho que parece nimio a los ojos de los demás pero que supone un gran deshonor para ellos, por lo que suplican a Aslan que se la devuelva o todos ellos se cortarán las colas en solidaridad con su jefe. Es en este momento cuando Aslan informa de cómo pagó su deuda con los ratones que le liberaron de las cuerdas: otorgándoles el don del habla. Y como nueva muestra de gratitud, ya que estos son los descendientes de aquellos, y asombrado por la solidaridad de los ratones, decide devolver la cola perdida al jefe de los roedores, pese a que le parece excesiva su obsesión por el honor (El príncipe Caspian, 2005: 265-268). 
Así pues, estos pequeños animalillos se han elevado, con su acción liberadora de las ataduras del felino, desde los denigrantes calificativos que Susan les dedica en el primer libro: "ratones horribles" y "criaturas mugrientas", a seres provistos de honor y que resultan de gran importancia. Su valía es tal que, en La travesía del Viajero del Alba (1952), nos informan de que Reepicheep recibió la profecía de una dríade al nacer. Al final de la obra, desembarca en su propio bote miniatura, desaparece y nos dan a entender que finalmente llega al País de Aslan, una especie de Paraíso, igual que Narnia pero sin defectos. Incluso se le llega a equiparar con la figura de San Pedro debido a su papel como personaje que da la bienvenida a los que llegan a este Paraíso en La última batalla (1956), cuando asistimos al final de Narnia.

De este modo, como vemos, el elemento central del ratón que libera al león de las ataduras que le aprisionan se mantiene, así como el del agradecimiento presente en la fábula esópica y el hecho de que, aunque algo parezca insignificante, como un ratón, puede resultar de utilidad a alguien que, a priori, es muchísimo más poderoso, al igual que en todos los casos anteriores. Si bien, al no existir la deuda de vida anterior por parte del roedor, lo que nos encontramos es el encumbramiento del ratón en una figura honorable, generosa, valiente y profundamente espiritual, cualidades que, ni en las fábulas, ni en el imaginario colectivo, son atribuidas jamás a los ratones.

Llegados a este punto, hemos podido observar que el armazón argumental principal se ha mantenido en los tres casos estudiados: la liberación del león de sus ataduras. Así como la doble enseñanza de la fábula, elemento esencial del género dado su afán didáctico: el valor potencial de lo que parece insignificante y el hecho de que ninguna buena acción queda sin recompensa, con independencia de que la recompensa sea del ratón al león o al contrario.

Pero, pese a ello, cada autor ha podido jugar con los elementos y adaptarlos en función de sus necesidades o intenciones. Cada uno, sin duda, ha proporcionado un estilo específico y característico a esas composiciones, reforzado algunos elementos, suprimiendo otros, ampliando la trama...y aun así, la fábula ha logrado mantener su esencia y su vigencia a través del tiempo, el espacio o el idioma.

\section{BIBLIOGRAFÍA}

Bestiario Medieval (1999), Madrid, Siruela.

Blecua, A. (Ed.) (1992): Libro del Buen Amor, Madrid, Cátedra.

Brunner-Traut, E. (2000): Cuentos del Antiguo Egipto, Madrid, Edaf.

Carpenter, H (2008): Los Inklings, Barcelona BibliothecaHomolegens.

Carpenter, H (1993): Cartas de J. R. R. Tolkien, Barcelona, Minotauro.

Cascón Dorado, A. (1987-1988): “Fenómenos comunes en la trasmisión del exemplum y la fábula", Habis18-19:173-185.

Cuesta Torre, M. L. (2008): “El ensiemplo del león y del caballo y la crítica a la caballería en el Libro de Buen Amor", Boletín de la Biblioteca Menéndez Pelayo, 84: 109-133. 
Cuesta Torre, M. L. (2012): “Las fábulas esópicas sobre leones del Libro del Buen Amor", en Natalia Fernández Rodríguez y María Fernández Ferreiro (eds.): 477-487.

Deyermond, A. (2007): “Leones y tigres en la literatura medieval castellana”, en A. López y L Cuesta (eds.): 41-63.

Fernández Rodríguez, N. y M. Fernández Ferreiro (2012): Literatura Medieval y Renacentista en España: líneas y pautas, Salamanca, Gráficas Cervantes.

Fradejas Rueda, J.M. et alii (2010): Actas del XIII Congreso Internacional de la Asociación Hispánica de Literatura Medieval, Valladolid, Universidad y Ayuntamiento de Valladolid.

García Gual, C. (1978): Introducción a Fábulas de Esopo - Vida de Esopo - Fábulas de Babrio, Madrid, Gredos.

Hervieux, L (1970): Les Fabulistes latins, depuis le siècle d'Auguste jusqu'à la fin du Moyen Âge. Vol. 2, Phèdre et ses anciens imitateurs directs et indirects, II. Paris. FirminDidot. 5 vols. reimp.Hildesheim. Georg Olms.

Lacarra, M.J. (2009): “Fábulas y proverbios en el Esopo anotado", Revista de poética medieval, 23: 297-329.

Lacarra, M.J. (2010): “La fortuna del Isopete en España”, en J.M. Fradejaset alii (eds.): 109-134.

Lewis, C.S. (2005): El león, la buja y el armario, Barcelona, Círculo de Lectores.

Lewis, C. S. (2005): El sobrino del mago, Barcelona, Círculo de Lectores.

Lewis, C.S. (2005): El príncipe Caspian, Barcelona, Círculo de Lectores.

Lewis, C.S. (2005): La travesía del viajero del Alba, Barcelona, Círculo de Lectores.

Lewis, C.S. (2005): La última batalla, Barcelona, Círculo de Lectores.

López Castro, A. y Cuesta Torre, M. L. (2007): Actas del XI Congreso Internacional de la Asociación Hispánica de Literatura Medieval, León, Universidad de León.

Morros Mestre, B. (2003): “El episodio de doña Garoza a través de sus fábulas (Libro del Buen Amor, 1332-1507), Nueva Revista de Filología Hispánica, 2: 417-464.

Pérez Díez, M.C. (2004): Por Siempre Jamás: C.S. Lewis y la Tierra de Narnia, León, Universidad de León.

Rodríguez Adrados, F. (1987): Historia de la fábula greco-latina, Madrid, Universidad Complutense. 



\title{
UNA MIRADA SOBRE LA FÁBULA ESPAÑOLA DEL XIX. LAS FÁBULAS DE PASCUAL FERNÁNDEZ BAEZA
}

JOSÉ ENRIQUE MARTÍNEZ FERNÁNDEZ

\author{
Universidad de León ${ }^{1}$
}

\section{Resumen}

En el siglo XIX la fábula española mantuvo una fecundidad semejante a la del siglo anterior. Este artículo analiza las fábulas políticas y morales de un autor casi olvidado de dicho siglo, Pascual Fernández Baeza, que ocupó altos cargos en la Magistratura y publicó algunas colecciones de fábulas con una doble finalidad: la sátira política y la educación moral de niños y jóvenes fundada en principios tradicionales como la obediencia, el estudio y el amor al trabajo. Destaca la variedad rítmica de las fábulas, que son un excelente muestrario de las combinaciones métricas de su época.

Palabras clave: Fábulas políticas y morales, Fernández Baeza, sátira, educación, principios tradicionales, variedad métrica.

\begin{abstract}
During the 19th century, the genre of the fable maintained the success it achieved during the previous century. This study analyses the political and moral fables of Pascual Fernández Baeza, an almost forgotten author who held senior positions in the judiciary and who published a number of fables with a dual aim; to work both as political satires and as models of moral education for children and young adults, based on traditional values such as obedience and the importance of studying and loving work. The rhythmic variety shown by the fables particularly stands out as an excellent sample of the metric combinations of the time.
\end{abstract}

Keywords: Political and moral fables, Fernández Baeza, satire, education, traditional values, rhythmic variety.

Tras el temprano florecimiento de la fábula en la España medieval, los Siglos de Oro la relegaron a una presencia esporádica en obras teatrales, ascéticas y picarescas. “Reapareció de la mano de La Fontaine con las Fábulas morales (1781) de Félix María Samaniego, que fijó el modelo de la fábula española moderna: se escribirá en verso con la mayor variedad métrica posible y se buscará como cualidad primordial la ligereza narrativa" (Navas Ruiz, 1973: VIII). Un año después editaba Tomás de Iriarte sus Fábulas literarias (1782). El éxito de uno y otro autor y el aprovechamiento de sus

\footnotetext{
${ }^{1}$ Correo-e: jemarf@unileon.es. Recibido: 03-01-2013. Aceptado: 15-03-2013.
} 
fábulas en la enseñanza hasta tiempos no muy alejados de nosotros los ha convertido en los clásicos del género por excelencia. Si en el XVIII la fábula se integró fácilmente en la corriente utilitarista del momento, que defendía la función didáctica y moral del arte, en el siglo siguiente el género mantendrá un cultivo pujante:

Aunque se considera el siglo XVIII como el propio de la fábula, ésta tuvo su apogeo en el siguiente y entre 1800 y 1900 he contado un centenar de autores españoles con uno o más libros en su haber. Bastantes tuvieron varias ediciones y algunos para uso escolar se reimprimieron de modo tan prodigioso como el Libro de los niños, de Martínez de la Rosa, que pasó de las setenta ediciones (García Castañeda, 1986: 574).

Las razones del éxito las explica Navas Ruiz:

El siglo XIX fue extraordinariamente fecundo en fabulistas. Y no es extraño si se tiene en cuenta que, por su naturaleza moralizante y por su exacta observación de la realidad, la fábula se aproxima a la literatura costumbrista tan en boga entonces, y es sumamente apta para la crítica social, ideal de una gran parte de la literatura decimonónica. Por otro lado, a un nivel de sociología literaria, la fábula se convirtió en España en el instrumento ideal para mantener una educación religiosa y moral sobre bases tradicionales de la que muy pocos -los mejores por supuesto y no siempre- supieron remontarse para reflejar las inquietudes y las tendencias nuevas (Navas Ruiz, 1973: 17).

Juan Eugenio Harzenbusch, Miguel Agustín Príncipe y Ramón de Campoamor son los fabulistas del XIX que han suscitado mayor interés, pero fueron muchos los que escribieron y publicaron colecciones de fábulas. Por no hacer un tedioso listado de los mismos, me limito a citar a los que, en su Fabulario español, Sainz de Robles consideraba "dignos de mención":

El magistrado y senador del Reino don Pascual Fernández Baeza, que publicó, en 1852, una Colección de fábulas políticas y morales; el diputado general de Vizcaya e historiador del Señorío de Guernica don José Agustín de Rentería -1750 a 1826-, cuyas fábulas han sido publicadas -1923por el erudito Alonso Cortés en una colección escogida de Fábulas castellanas; el sacerdote y abogado, profesor de Religión y Moral de don Alfonso XII, don Cayetano Fernández, de la Academia Sevillana de Buenas Letras, autor de unas Fábulas ascéticas; el oidor de la Audiencia de Aragón y consejero de S. M., don Rafael José Crespo (1789-1849), que dedicó sus Fábulas y epigramas al ministro Calomarde; don Juan Pisón y Vargas, autor de unas Fábulas políticas y morales, muy alabadas por Núñez de Arce (Sainz de Robles, 1964: 17).

No escasea la bibliografía crítica sobre Hartzenbusch y Campoamor, pero, salvo excepciones, los demás han merecido escaso aprecio.

En la larga lista de fabulistas españoles del XIX figura, como hemos visto, Pascual Fernández Baeza, en buena parte olvidado, pero que en su época gozó de cierta consideración. Nació en Ponferrada en 1798, dentro de una familia de la nueva burguesía que disputaba el poder al Antiguo Régimen. Realizó sus primeros estudios en su villa natal, estudios que tuvo que interrumpir con la entrada en ella de las tropas francesas el 3 de enero de 1809, huyendo con su familia a las montañas vecinas. Los reanudaría en Monforte de Lemos. Cursó Derecho en Valladolid, concluyéndolo en 1819 y ejerciendo, a partir de ese momento, distintos e importantes cargos dentro de la Magistratura: Promotor fiscal de su villa natal a partir de 1821, Corregidor en Lugo, Magistrado en la Audiencia de Valladolid, Fiscal y ministro en la de Madrid 
nombrado en agosto de 1843, miembro del Consejo Real en 1853...; se jubiló siendo Vocal supernumerario del Tribunal contencioso-administrativo (García, 2008).

\begin{abstract}
Este berciano, de no genial, pero sí precoz y claro talento, de afable trato y palabra cariñosa y convincente, de risueña faz y educadísimas maneras, de actividad incansable y ejemplar integridad, de ideas liberales y militante activo contra el absolutismo de Fernando VII, fue un entusiasta empedernido del progreso de la provincia, a pesar de que -como tantos otros- vivió fuera de ella largo tiempo, pero a la que representó en el Congreso de los Diputados desde 1836, y en el Senado en 1851 (Martínez García, 1982: 326).
\end{abstract}

Murió Fernández Baeza en Madrid en 1860.

Este hombre de "vigorosa conciencia ciudadana" (Carnicer, 1984), es autor del Método práctico de sacar apuntes y formar extractos, claros y exactos del resultado de los procesos (1843), libro que en su tiempo hizo buen servicio a los auxiliares de Justicia; elaboró una muy celebrada Estadística criminal del territorio de la Audiencia de Madrid (1849), un reglamento de las cárceles de la Corte y una obra de gran empeño que dejó inacabada, Fundamentos de la Legislación. Fue hombre preocupado por cuestiones arqueológicas, hasta el punto de presidir durante algunos años la Academia española de Arqueología y Geografía. Literariamente, gustó de la poesía y publicó algunas composiciones en periódicos provinciales; en 1854 publicó en Ponferrada A Fabio. Epístola satírica en que se describen los vicios políticos y morales de la Corte, larga composición de 212 versos que citamos aquí porque coincide con la intención que movió la escritura de su Colección de fábulas políticas y morales, publicada en 1852, y de su Nueva colección de fábulas morales, (tomo II) que apareció en 1858. La primera dio fama al jurisconsulto, sobre todo por ser declarada de lectura obligatoria en las escuelas públicas.

A la fábula se le ha asignado, entre sus finalidades, la de la educación moral, por lo que desde el principio fueron consideradas muy útiles en la enseñanza, aspecto subrayado por títulos como Fábulas de la educación (1871) de Antonio Trueba y Carlos Pravia, Moral infantil (1876) de Manuel Osorio Bernard, El amante de los maestros (1894), de Andrés Codoñer, etc., etc. El éxito escolar de la fábula se prolongó durante buena parte del siglo XX. María Rosario Ozaeta anota que en las doscientas páginas del libro primero de las Lecturas graduadas, publicadas en 1953 por la editorial Luis Vives, hay cinco fábulas de Esopo, cinco de Samaniego, dos de Iriarte, dos de Hartzenbusch, dos de Antonio de Trueba y una de cada uno de los siguientes autores: Manuel del Palacio, Campoamor, Cayetano Fernández, Florian, Príncipe, Schmid y Fernández Baeza, y añade que igual ocurre con otros libros escolares, lo que muestra "la gran profusión, así como del carácter pedagógico y moralizante de la fábula, tanto en la segunda mitad del XIX como en la primera mitad -y a veces más allá- del siglo XX" (Ozaeta).

Como hemos adelantado, en 1852 publicó Fernández Baeza su Colección de las fábulas políticas y morales. Bajo el nombre del autor venía la siguiente anotación: "Presidente de la Sala de la Audiencia de esta corte, Senador del Reino, y antes constantemente Diputado por el distrito de Ponferrada". El prólogo a la colección es instructivo respecto a las circunstancias de composición, al entendimiento y finalidad de las fábulas y a la razón de su publicación. No parece -si nos atenemos a sus palabrasque Fernández Baeza tuviera en excesiva estima a la poesía en general. Al fin y al 
cabo sólo le dedicaba, como a ocupación menor, los escasos momentos de ocio de que disponía:

Siempre he considerado como un precioso tesoro el hábito del trabajo. Para no interrumpirle, desde mis primeros años acostumbré a emplear en estudios agradables los breves ratos que las atenciones de mi carrera me dejaban libres. Con el mismo propósito en los últimos tiempos dediqué al cultivo de las Musas aquellos momentos de que en los días de fiesta o vacaciones me permitían disponer mis deberes como magistrado, individuo del Congreso, y presidente de varias juntas.

Es, por lo tanto, ocupación esporádica la de la poesía, un género que no requería ni mucho tiempo ni la continuidad de otro tipo de obras: "composiciones ligeras" las denomina, es decir, leves, de escasa importancia, por lo que la fábula, aunque "ficción ligera y expresiva", le pareció, dentro de lo poético, más acorde con el viejo precepto ilustrado de "enseñar deleitando". Por otro lado, la fábula le parecería a Pascual Fernández Baeza, "modalidad muy concorde con el espíritu crítico, moralizante y aleccionador de su vocación jurídica" (Carnicer, 1984). Dos finalidades vio nuestro escritor en la fábula que la hacen más digna que el mero pasatiempo versificador: la moral, enseñanza dirigida a niños y jóvenes, y la satírica, encaminada a la actividad política, que conocía bien. De ahí el título de su colección y la división en dos partes, políticas y morales atendiendo a una y otra finalidad. Sigamos sus propias palabras:

En medio de semejantes ocupaciones no me era posible emprender ninguna obra de las que requieren profunda mediación y largo empeño, sino que debía reducirme a composiciones ligeras de las que se conciben y trasladan al papel rápidamente. Huyendo de la frivolidad, di preferencia a la fábula, ficción ligera y expresiva, cuyo principal objeto es formar el corazón de la infancia y de la juventud, imprimiendo con indeleble estampa máximas de sana moralidad y costosas lecciones de la experiencia. Obedecía también por este camino al instinto que naturalmente me inclina a fustigar con las armas del ridículo los muchos vicios de que nuestra sociedad política adolece: empleos ambos muy conformes a la solicitud de un buen patricio, y al carácter de un magistrado².

Si hacemos caso a don Pascual, sólo escribirá sus fábulas para recitarlas en familia (las morales) o entre los amigos (las políticas). Algunas se publicaron en el periódico Laberinto, y al leerlas "uno de nuestros literatos más insignes", nos dice, le animó a seguir escribiendo fábulas y, a instancia de otras gentes, a publicarlas.

La Colección de las fábulas politicas y morales de 1852 consta de dos partes, conforme al título; después de una pieza de introducción ("Los dos niños"), son 22 las fábulas políticas, a las que siguen cinco epigramas, y 48 las morales. La última, “Fábula verdad. La vida del hombre" no es propiamente una fábula, que antes ha definido como "ficción ligera y expresiva"; en cambio, la última es una "fábula verdad" que contrapone a las demás; el soneto -también en eso se distingue el poema, pues es el único de la colección- es una paráfrasis poética del tópico de la vida como río que en nuestra lengua acuñó Jorge Manrique. Las fábulas morales disfrutaron en 1953 de una segunda edición aumentada con siete fábulas nuevas: Colección de fábulas morales, "declaradas de texto para las escuelas", como expresa la portada.

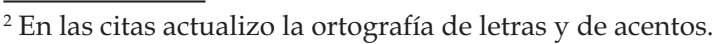


En 1858 apareció un tomo primero titulado Nueva colección de las fábulas políticas y morales de Pascual Fernández Baeza, “Senador del Reino y Consejero Real Jubilado”, y un tomo segundo, Nueva colección de fábulas morales, que figura como tercera edición aumentada; en este caso, bajo el nombre del autor se lee lo siguiente: “Consejero real jubilado, Senador del Reino, y antes de serlo, constantemente Diputado a Cortes por el distrito de Ponferrada, su patria"; este tomo segundo lleva exactamente el mismo prólogo que la colección de 1852, pero el tomo primero añade a aquel prólogo, que también incluye, algunas páginas más; en ellas aclara que fue Juan Nicasio Gallego (1777-1853), uno de nuestros últimos poetas neoclásicos, quien le incitó a la publicación de aquella inicial colección y que además valoró cada una de las fábulas, y cita las revistas y periódicos que se ocuparon de la colección de 1952: El Observador, La Esperanza, La Nación, La Época, La Ilustración, El Universo Pintoresco y La España, con firmas de Velisca (Seudónimo), Pedro Calvo Asensio y Eugenio Ochoa, que era Director de Instrucción Pública. Añade que se ocupó también de sus fábulas Joaquín María López en sus Lecciones de elocuencia impartidas en el Ateneo y publicadas en 1856. Todo ello le infundió estímulos para escribir nuevas fábulas, pero con una diferencia, a su parecer, de las anteriores:

Había hasta entonces prescindido del adorno de la descripción para concentrar más y más el pensamiento; pero me decidí a componer algunas fábulas descriptivas a fin de darles novedad, y agradar a los que anteponen a la concisión lo florido de las descripciones.

En efecto, así es en determinadas fábulas, en las que la descripción tiene algo de amplificatio, aunque ganan en plasticidad.

En el prólogo explica Fernández Baeza que el número de fábulas creció tanto que se vio obligado a publicar dos tomos, organizado cada uno de ellos en dos libros: el primero de cada tomo acoge las fábulas publicadas en 1852; el segundo libro, las fábulas nuevas; el primer tomo es todo él de fábulas políticas (38 fábulas más una pieza de introducción, "Los niños", y un epigrama) y el segundo de fábulas morales (80 en total, introducidas también por "Los niños"). Añade el autor dos cuestiones más: la primera, que las fábulas morales fueron declaradas "útiles para la enseñanza de la niñez" por Real Orden de 16 de mayo de 1853 y que con idéntico fin escribió en verso las oraciones de la iglesia (Padre Nuestro, Ave María, la Salve, el Credo, etc.) que unió a ellas en la Nueva colección; la segunda cuestión es que, antes de publicar las nuevas fábulas buscó la opinión crítica de calidad, en este caso de Antonio Alcalá Galiano y Eugenio Moreno López.

Una vez explicados los pormenores o circunstancias externas de las colecciones de 1852 y 1858, se trata de estudiar las fábulas políticas por un lado y las morales por el otro. Pero a unas y otras las encabeza la misma composición, “Los niños", como hemos reiterado, en razón de que en ella ofrece el autor la finalidad de sus fábulas: “También como el niño / a nadie reprendo: / los vicios tan solo / atacan mis versos: / y aquel que se ofenda / confiésase reo". 


\section{FÁBULAS POLÍTICAS}

"La fábula política española en el siglo XIX" fue estudiada parcialmente por García Castañeda (1986: 576-575). En su trabajo revisa, cronológicamente, las escritas por fray Ramón Valvidares, Cristóbal de Beña, Pablo de Jérica, José María Gutiérrez de Alba, Hartzenbusch y Fernández Baeza, para concluir que los ejemplos escogidos:

Muestran la vida española desde 1808 hasta mediados de siglo cuando gobiernan los "espadones" de turno, y porque reflejan el modo de pensar de quienes representan a esas "dos Españas" que se enfrentan en el XIX. He aquí el patriotismo a ultranza de un P. Valvidares absolutista, el combativo constitucionalismo de Beña y de Jérica, la verborrea demagógica de Gutiérrez de Alba, tan característica de aquella juventud democrática de los años 40, el escepticismo de un Hartzenbusch testigo del desgobierno de España durante medio siglo y, por fin, el liberalismo templado del magistrado Fernández Baeza, quien veía los problemas del país en términos legales y parlamentarios (García Castañeda, 1986: 575).

Las fábulas políticas de Fernández Baeza van dirigidas contra los vicios de quienes ejercen el poder (el gobierno, los diputados) y contra quienes lo jalean (los periodistas, pongamos por caso). Tienen, como es lógico, un punto satírico. Como indica García Castañeda, el magistrado Fernández Baeza fue siempre un liberal que con los años evolucionó hacia el moderantismo, algo que no puede seguirse por las fábulas al recogerlas sin orden y sin consignar la fecha de las mismas. Añade dicho estudioso:

Asuntos de varias es el despotismo, oprobio de los pueblos, aunque el déspota de hoy ya no es el rey, sino los gobiernos conservadores: unas yeguas a las que molesta un Lobo acuden al Tigre para que las defienda y éste acaba por devorarlas. La moraleja aclara: "Si es un mal la agitación / del gobierno liberal, / es la calma sepulcral / bajo la dominación / de un déspota, mayor mal" ("La yeguada").

La escena política reflejada aquí no ha cambiado con los años. Los candidatos siguen ofreciendo libertad y mercedes a sus electores y cuando llegan al poder no cumplen lo prometido ("El Pollo y las Gallinas"), los mejores puestos continúan en manos de trepadores y adulones, y el gobierno, que está encargado de dar leyes, es el primero en quebrantarlas ("El Lobo y el Zorro"). La moralidad pública no existe cuando los gobernantes se enriquecen a costa del erario ("El Lego y el Santo"), y tanto la oposición como la prensa, que tiene a su cargo el denunciar los abusos, dejan de hacerlo cuando les conviene. Así lo ilustra la fábula del perro que ladraba indignado a un gato que devoraba un jamón robado hasta que cayó un pedazo al suelo y el perro dejó de ladrar para comerlo: “A cuántos como el perro he conocido / que lanzando al gobierno ataques rudos, / un trozo de turrón los dejó mudos." (García Castañeda, 1986: 574).

Señala el mencionado crítico que el magistrado que fue don Pascual veía, en cambio, "la felicidad del país en la observancia de la ley y no en la revolución":

Advierte en contra de las coaliciones de partidos opuestos porque traen confusión y anarquía ("Los monstruos"), previene a los españoles contra la pasión partidista que hace olvidar los verdaderos intereses de la patria ("Los gallos"), y recuerda a los ambiciosos la vieja máxima de que la Revolución devora a sus propios hijos: "Todo el que suba al poder / por una sublevación, / debe esperar con razón / que le llegue a suceder / quien tenga igual ambición" ("Los Lobos").

La sátira del fabulista va dirigida contra el favoritismo y el mayor aprecio de la apariencia vana que de la virtud y el trabajo y contra los vicios y la corrupción del poder y el dinero. Siguiendo el hilo de las diferentes fábulas, Fernández Baeza critica a la sociedad y la comunidad política, que aprecian y premian más la apariencia que el 
mérito verdadero (“La abeja y el grillo", “El pollo y las gallinas”, “Las notabilidades”...), a los comprados o corrompidos por el poder o el dinero ("El perro y el gato", “El reclamo", "El perro rabioso"), censura los discursos vanos de diputados aparentemente serios ("Los grajos"), a los que abdican de votar en conciencia por miedo o cobardía o buscando el propio provecho ("El congreso de animales"), a los aduladores (“Los dos perros"), el falso patriotismo, la hipocresía de los que mandan, que hacen lo contrario de lo que dicen... Ataca al periodismo adulatorio del poder ("El reclamo") y al petulante a la vez que ignorante ("El mono y la zorra", "Los gozques”). La sátira cae contra el gobierno que quebranta la legalidad ("El lobo, el zorro"), contra la anarquía de cada uno por su lado ("Los colores"), contra los que, fiados de vanas teorías y proyectos, sin trabajo ni experiencia, pretenden el gobierno: "gran mal que a España aqueja", escribe el fabulista en "La receta", que subtitula "Cuento", pues cuento en verso es: un anciano experimentado hace ver a un joven inexperto y presuntuoso la necesidad del trabajo y la práctica previas a cualquier tarea de gobierno.

En las 16 nuevas fábulas políticas de 1958, la sátira es, a mi parecer, más directa contra los abusos de poder y contra el mal gobierno, contra el combate político cuyo pretexto es únicamente hacerse con el poder ("Los gallos”), contra la multiplicación de partidos para obtener algo del botín cuando no hay para todos (La langosta"), contra los gobernantes que resisten en el poder y llevan el país al desastre, como ocurre con el piloto que sin oír las advertencias del timón lanza su buque al naufragio ("El timón y el piloto"); contra la ambición política ("El ciervo”), etc. Pero, en efecto, como advertía García Castañeda, el magistrado don Pascual, liberal moderado finalmente, no creía en la revolución como redención del pueblo: al ejemplo anterior de "Los lobos" podemos añadir la fábula -cuento más que fábula- de "El arroyo", en el que una joven llena su cántaro mientras su plácida corriente no se convierte en "furioso torrente" que arrasa cuanto encuentra a su paso: “Como la bella joven, patria mía, / en las revoluciones / que bastarda ambición promueve y guía, / hallarás que dominan de igual modo / que al arroyuelo el sucio fango y lodo, / las sórdidas pasiones, / y destruyen, y arrasan las naciones".

Metido en la batalla política, el Senador del Reino y Diputado por el distrito de Ponferrada ¿añoraría alguna vez la tranquilidad de su villa natal? La larga fábula "El ciervo" es una amarga sátira de la ambición política. El animal que plácidamente campaba por valles y selvas es elegido "valido" del rey y acaba siendo odiado por todos, hasta el punto de caer del poder y no hallar donde cobijarse; y el fabulista exclama: “¡Ay quién de ti se fía, / oh política, y, ciego / por la ambición, tomándote por guía, / del campo deja el plácido sosiego!".

A las fábulas políticas siguen en la colección de 1852 cinco epigramas que participan del mismo tono satírico-político que las fábulas, atacando el cambio de principios según la conveniencia, la ignorancia de quienes rigen los destinos de la Patria, el medro de los habilidosos frente a los esforzados, etc. 


\section{FÁBULAS MORALES}

De acuerdo con el prólogo ya comentado de la Colección de las fábulas políticas y morales de 1852, si aquellas tenían una finalidad satírica, las morales, lógicamente, arbitraban una finalidad moral dirigida a jóvenes y niños. La fábula era acaso, como ya anunciamos, el género más propicio para instruir deleitando, para ofrecer una enseñanza moral por medio de una narración gustosa o amena.

Cuarenta y ocho son las fábulas de la mencionada colección de 1852. Al año siguiente, al publicar la segunda edición de las morales (Colección de fábulas morales) se añaden siete más y se prescinde de una, "Las gallinas"; son las que reitera en 1858, añadiendo 26 nuevas. En total son 80, por lo tanto, las fábulas morales publicadas por Fernández Baeza, número más que suficiente para darnos cuenta de cuánto le preocupaba al magistrado la formación moral de niños y jóvenes. De hecho, en muchas de las fábulas los propios niños se convierten en protagonistas, algo visible en títulos como "El niño y el pájaro", “El niño y el canario”, “El niño y el cazo”, "El niño y el ciervo", “Los niños y los galgos”, “Las dos niñas”, “El pequeño”, etc. En otros casos, la moraleja explicita su destinatario: "Si os dieren joh niños! / consejos villanos, / obrad como el perro / guardián del ganado" ("El lobo y el perro del ganado"). La misma métrica (romances, redondillas, seguidillas, versos tetrasílabos en algunos casos...) colaboraba en la pretensión de que la fábula fuera asequible y fácil de memorizar por su ritmo tradicional e incluso por su brevedad en muchos casos.

Dada la cantidad de fábulas morales no es fácil sintetizar los motivos que las mueven; en cualquier caso son, como es lógico, principios tradicionales, como la obediencia, el amor al trabajo, etc. Un buen número de fábulas se centran en la necesidad del estudio y la aplicación al mismo: "El niño y el canario", "Los niños y los galgos", "El premio o los dos niños" o "El golpe", que añade a las cualidades naturales (el genio) el estudio para lograr un buen resultado, etc. Otras, como “El pelícano y el tiempo" o "El camello y la hormiga", cercanas temáticamente, celebran el trabajo, el esfuerzo, el sacrificio y la constancia, virtudes que tarde o temprano acabarán dando fruto. En este ámbito algunas fábulas proponen trabajar en aquello de lo que se alcance algún fruto ("Las conchas", "Las dos niñas"), la unión de estudio y experiencia ("El teórico") y trabajar no para el presente sino para lograr la felicidad eterna ("El cerdo y el gusano de seda").

El cuidado y la prudencia en el obrar es la enseñanza que se extrae de fábulas como "El niño travieso", "Los gatos y el niño", "El galápago y la lagartija" o "La aldeana". El hacer el bien no sólo es conveniente, sino que suele tener su recompensa ("El oso y el perro de San Bernardo”, “Las niñas y el hortelano”); en este campo, hay que mostrarse agradecidos y leales con quien nos hace bien ("El gozque y el mastín", "El lobo y el perro de ganado"). En otras fábulas ("El feo", "El pequeño", "El tuerto" o "La cojera") se concluye con que es el valer y la hermosura interior del alma lo que importa, por encima de las apariencias físicas; otra enseñanza es que importa más el propio valer que el que se apoya en el valer de otro ("La hiedra y el avellano”), y más lo que uno es que lo que aparenta, como expresa la moraleja de "El rocín y el caballo". 
Algunas composiciones hablan de la necesidad de la buena amistad como ayuda para evitar peligros en la vida ("El perro de lanas y el cachorro de caza"), por lo que tal amistad hay que cuidarla, sin abusar del amigo, como en "La urraca y el perro de lanas" hizo aquella con el segundo.

Si las anteriores son propuestas positivas, otras fábulas hablan de vicios que el niño y el joven han de combatir, como la mentira ("El niño y el galgo inglés”), el orgullo y el engreimiento ("La cometa"), la presunción, la avaricia ("La comadreja y los ratones"), la gula desconsiderada, la envidia ("El perro y el gato", "La luna y los vapores"), las acciones traicioneras y engañosas ("El perro, la zorra y el lobo"), la ambición que lleva a querer destacar, sin formación suficiente, antes de tiempo ("El albillo agraz y la fresa") o a ilusionarse con salir de su "honesta medianía" ("Los niños baleares").

Capítulo importante en las fábulas de Fernández Baeza son las jóvenes, la formación moral de las jóvenes. No le podemos pedir al magistrado y fabulista que fuera un adelantado a su tiempo, un tiempo en el que la mujer desarrollaba su vida en el ámbito familiar y cuyo destino consistía en ser buena madre y buena esposa, sin autonomía personal ni laboral ni independencia económica. La educación, bajo el secular paraguas de la Iglesia, formaba mujeres piadosas que fueran expertas en "las labores propias de su sexo", según fórmula muy utilizada en la época. Nuestro fabulista vela por la mujer prudente, cautelosa, de modales dignos, atenta a la belleza interior más que a la externa. Al hilo de las fábulas que tienen como destinataria directa a la mujer, podemos establecer algunos grupos temáticos, según sus propuestas morales. En el primero y más abundante situaríamos aquellas fábulas que previenen contra el amor engañoso; la fábula más atractiva en este ámbito es "Las sirenas": con el eco odiseico de las sirenas y Ulises se previene a las jóvenes contra los cantos de sirena engañosos de quienes las adulan: "Inocentes, del canto fementido / de insidiosos amores, / y sus tonos traidores, / apartad, cautelosas, el oído". De igual modo, se previene a las confiadas en su experiencia ("La corona”). No es ajeno a nuestro tiempo el hecho de que la sociedad disculpe al seductor, pero denigre a la seducida: "Si alguna se abandona, / el mundo no perdona / su perdición, y achácale la culpa: / mientras al seductor se le disculpa" ("Los gatos con peste"). Más aún, es a la mujer a la que se culpa de los desmanes del hombre: “¡Cuántas jóvenes del día, / al erizo abierto iguales, / dan margen con sus modales / y gestos, a la osadía" ("Los dos erizos de castaño"). Otro tema es el del valor de lo natural e interior frente a lo artificioso y exterior ("El barniz"). Un tercer tema atañe a la mujer virtuosa: “Jóvenes, sed virtuosas: / inspiraréis puro amor; / y no, cual mariposas, / aficiones peligrosas, / fruto del brillo exterior" ("El niño y la mariposa"). Finalmente las actitudes de la mujer en el matrimonio inspiran otras fábulas, acaso las más curiosas y las que mejor muestran el lado conservador de don Pascual Fernández Baeza. El hogar como lugar propio de la mujer aparece en "Las dos primas": “¡Jóvenes! en el amor / de los hijos y el esposo, / y doméstica labor, / se halla el goce encantador; / no en el festín bullicioso". Al marido, en cambio, hay que dejarle suelto: "La que conservar quiera / un amante sincero, / no olvide por bien suyo / lo del niño y el ciervo", es decir, que no sujete al ciervo (el 
amante) como un carcelero, pues acabará huyendo buscando libertad. Es probable que "Las dos gallinas", de la colección de 1852, desapareciera en las ediciones siguientes por la propuesta de perdonar en el casado lo que a la casada no se le perdonaría: "Si un delirio cometieren los maridos, / sed prudentes, esposas; / buscadles cariñosas, / y prestos los veréis arrepentidos".

En resumen, don Pascual alaba a la joven prudente que cierra oídos a halagos y palabras engañosas, a la mujer cuya belleza natural no debe ser resaltada artificiosamente, a la mujer modosa, comedida, modesta, de ademanes honestos, a la mujer que no se confía, siempre prevenida contra los posibles engaños del hombre, y, en fin, a la mujer hogareña que halla la felicidad en el seno familiar.

\section{MÉTRICA}

La habilidad métrica de los principales fabulistas españoles ha sido generalmente reconocida, de Iriarte sobre todo entre los del XVIII, pues los recursos métricos de Samaniego, más monótonos y previsibles, "son inferiores a los de Iriarte: la rima es pobre, basada en múltiples ocasiones en verbos y adverbios; predomina la silva, que le permite gran libertad, y son frecuentes las estrofas de cuatro versos y los pareados" (Sotelo, 2000: 52). La riqueza rítmica de Tomás de Iriarte, en cambio, la han manifestado tanto los estudios de métrica española como los que versan sobre el fabulista canario. De Navarro Tomás son estas expresivas palabras:

El ejemplo de Iriarte debe notarse, no sólo porque ensayara una variedad de metros no igualada por ningún otro autor contemporáneo ni anterior a su tiempo, sino por el sentido artístico que, dentro del tono sencillo y familiar de sus fábulas, supo tener por guía al acomodar a cada ocasión el efecto rítmico más adecuado [...]. Sin inventar ningún verso que no tuviera precedente en español, contribuyó a restablecer modelos olvidados, a dar vida propia a tipos especiales que hasta entonces no se habían usado de manera independiente y a popularizar sus experiencias por todas las áreas del idioma (Navarro Tomás, 1974: 344).

“Iriarte consiguió en las Fábulas el repertorio métrico más rico de todo el siglo XVIII" ha consignado un editor de sus fábulas, que considera que el género permite mucha versatilidad rítmica (Prieto de Paula, 1992: 91). Acaso por eso, los fabulistas del siglo XIX se caracterizan, como Iriarte, por la variedad métrica de su producción fabulística, empezando por Hartzenbusch, pues "desde el amplio ritmo de la silva al alegre de la seguidilla, casi todos los versos y estrofas del español están representados en las Fábulas" (Navas Ruiz, 1973: XXII). En cuanto a Miguel Agustín Príncipe, él mismo certificó en el título la diversidad rítmica de sus composiciones y su interés por los aspectos métricos: Fábulas en verso castellano y en variedad de metros... precedida de un prólogo que contiene la historia de la Fábula desde Esopo hasta nuestros días y seguida de un "Arte métrica" (dos tomos, 1861-1862).

Pascual Fernández Baeza no les va a la zaga a los nombrados en variedad métrico-rítmica y en el intento de acomodar el ritmo a la materia grave o ligera de la fábula. Podemos decir que utiliza todos los metros que van del trisílabo al dodecasílabo, en las diversas combinaciones que la tradición métrica había ya experimentado. En 
este sentido no es Fernández Baeza un innovador, como no lo fue tampoco Iriarte, pongamos por caso. Ni lo fue ni podíamos esperar que lo fuera.

La única composición en versos trisílabos es "El niño, el perro y el gato", que, dada la rima asonante de los versos cuarto y octavo de cada estrofa, en la práctica lectora se convierten en una sucesión de versos hexasílabos en forma de romance o romancillo, como demuestra otra fábula, "El mochuelo", un romancillo hexasilábico cuya moraleja de doce versos trisílabos no es más que una configuración más airosa de los hexasílabos divididos en sus hemistiquios: “Lectores, / creedme: / a muchos / por serios / y darse / gran tono / guardando / silencio, / / les tienen / por sabios / y son ¿qué? / Mochuelos".

El verso de cuatro sílabas, utilizado como quebrado en poemas de versos octosílabos, no se empleó de modo independiente hasta el neoclasicismo y el romanticismo (Domínguez Caparrós, 1999: 428) y alcanzó “amplia representación con las fábulas La urraca y la mona y La ardilla y el caballo, de Iriarte" (Navarro Tomás, 1974: 335). Lo utilizó Fernández Baeza en estrofas de doce versos divididas en dos partes simétricas en cuanto a la disposición de las rimas. La división la marca la consonancia aguda entre los versos 6 y 12. Vemos tal estrofa duodécima en "El premio o los dos niños", donde todos los versos 6 y 12 de cada estrofa riman en -ón, y en "El lego y el santo" cuya disposición de rimas presenta esta forma: $-a-a-b-c-c-b$. La fábula "Los dos perros" presenta un juego de rimas más trabado: -abbac-deedc; tanto el verso corto como la disposición de las rimas reproduce rítmicamente la inquietud del perrito y su ladrido persistente: “Un doguito / le mostraba / a su dueño / duro ceño, / y ladraba / con furor, / hasta tanto / que veía / que atendido / su chillido / le decía: / 'Ladrador' ".

El verso pentasílabo lo usa Fernández Baeza combinado con el heptasílabo en las seguidillas, relativamente frecuentes. La seguidilla usada por nuestro fabulista es, sin excepciones, la llamada compuesta, es decir, la que a los cuatro versos tradicionales une un estribillo de tres versos, el primero y el tercero pentasílabos que riman en asonante, y el intermedio heptasílabo blanco. Indica Domínguez Caparrós que esta forma de seguidilla se extiende a partir del siglo XVIII (1999: 373), en el que alcanzó mucha popularidad. Fernández Baeza usa la seguidilla compuesta en nueve composiciones al menos, casi siempre breves, reducidas a una, dos o tres seguidillas: "La cometa", "Las apariencias", "El barniz", “Los gases", “El golpe”, "La modestia” y "El camello y la hormiga". Son, las de una sola seguidilla sobre todo, ejemplo de síntesis y escasez de acción.

Los demás versos de arte menor, hexasílabos, heptasílabos y octosílabos, los usa Fernández Baeza en variadas combinaciones. El romance es una de ellas. Los hexasilábicos o romancillos, de ritmo ligero y andadura ágil, los vemos en "El mochuelo", "El lobo y el perro de ganado", "La langosta" y "El perro rabioso"; en éste, con cierto alarde de ingenio, van alternando los estribillos "por fatalidad" y "por casualidad". 
El romance heptasílabo lo emplea en "El ciego y su sobrino", "El galgo", "El niño travieso", “Los gatos y el niño", "El niño y el ciervo", "La abubilla y el armiño", “El asno presumido" y “La abeja y el zángano.

El romance propiamente dicho, en octosílabos, aparece en fábulas como "La receta", "El niño y el pájaro", "Las dos golondrinas" y "La luna y los pájaros".

Fernández Baeza nos da buena muestra de distintas modalidades estróficas en versos de arte menor: pareados en "El feo" y "Las niñas y el hortelano"; redondillas en "La cola”, “El lebrel y el mastín”, “El niño y el canario” y otras catorce o quince composiciones más, lo que nos indica el aprecio por una forma que los poetas neoclásicos habían desechado y los románticos volvieron a recuperar; cuartetas en "El albillo agraz y la fresa”, "Las dos niñas" y algunas fábulas más; en quintillas se desarrollan fábulas como "La cojera”, "El teórico, “Las dos primas" y "La aldeana”, pero a la quintilla recurrió principalmente para la moraleja en fábulas dispuestas en otras modalidades estróficas: los romances de "El niño y el galgo inglés" o "Los dos alhelíes", por ejemplo, terminan con una quintilla; la fábula "Los dos gallos", en cuartetos endecasílabos, termina con esta quintilla: “Quien con violenta opresión, / abusando del poder / causa injusta vejación, / a los hombres de valer, / les da más grande opinión". Pero el fabulista berciano experimenta también con otras formas métricas más complejas como la octavilla y la décima. La octavilla aguda, en dos semiestrofas simétricas con pausa marcada, la practicó en "El rocín y el caballo" y en “El glotón" con una misma fórmula: $-a a b-c c b$, donde los vv. $4^{\circ}$ y $8^{\circ}$ terminan en aguda: era la misma que popularizó Espronceda en la "Canción del pirata". En cuanto a la décima, sólo la utilizó en dos fábulas: "La perpetua y la rosa" y "La araña".

El endecasílabo es, con mucho, el verso más usual del arte mayor, en muy diferentes combinaciones: pareados ("El oso y el perro de San Bernardo" y algunas fábulas más), tercetos encadenados ("El pólipo"), cuartetos y serventesios ("Los colores”, "Los dos gallos”, “El congreso de animales”, “El pastor”, “La hiedra y el avellano”...), octavas reales ("El avestruz y el ruiseñor", una sola octava).

Lo más frecuente es la combinación del endecasílabo con el heptasílabo en variadas modalidades estróficas: serventesios en "Los ochavos y las monedas de plata": $A b A b$. Otras combinaciones con rima consonante, todo un muestrario, son: $A b a B$ ("El ganso legislador"), $a B a B$ ("El perro y el gato", “El asno fanfarrón"), abaB ("La violencia"), aBAB ("El perro, la zorra y el lobo"), AbAB ("El timón y el piloto", "El lagarto y el zorro"), AbbA ("Las dos gallinas", "Las sirenas"), aBBa ("La abeja", “La envidia”), aBBA ("Los gozques”), aaBB ("Las alquitaras", “El gato, la zorra y el galgo", pareados pero dispuestos en forma de cuartetos, como "La mona", "Los gatos con peste" y "El mono y la zorra", en esta fábula con la fórmula $a A b B$ ). En cualquier caso, son combinaciones que se emplearon mucho tanto en el neoclasicismo como en el romanticismo (Navarro Tomás, 1974: 310 y 355). 
Combinación diferente es la de "El perro de lanas y el cachorro de caza", fábula que alterna heptasílabos (impares) y endecasílabos (pares), de modo que aquellos son blancos y los pares o endecasílabos, asonantados en -á-o, manteniendo por lo tanto, una estructura romanceada.

La silva, con su libertad o falta de disciplina formal, fue muy propicia para el desarrollo de cualquier tipo de asunto; la emplearon los distintos fabulistas y la usó también Fernández Baeza en "El convite”, "El arroyo”, “El cuervo”, “Los niños aleares, "La cigüeña y el mirlo" y "El pelícano y el tiempo".

Ocasionalmente emplea el dodecasílabo, sólo en "El ruiseñor y sus hijos", en serventesios.

De mayor originalidad son las combinaciones con rima asonante. Formas asonantes emplea Fernández Baeza en combinaciones de decasílabos y hexasílabos, algo que se da en "El milano y las palomas", "La cigüeña y el gorrión” y "El manzano y la castaña", con esta estructura a lo largo de cada composición: A b A b A b A b... Los impares son decasílabos y riman todos entre sí y los pares, hexasílabos, riman también entre ellos con rima diferenciada de los decasílabos. Por otro lado, los decasílabos llevan acento en tercera, sexta y novena sílabas (decasílabo anapéstico o de himno) y los hexasílabos en segunda y quinta (anfibráquico). Algunos ejemplos: “La cigüeña y el gorrión" se compone de 32 versos distribuidos por el sentido en cuartetos: los impares, decasílabos, riman todos en -é-a y los pares, hexasílabos, todos en -á-o; “El manzano y la castaña" es una larga fábula de 56 versos en la que los decasílabos o impares riman en -é-o y los pares o hexasílabos en -á-o; en "El milano y las palomas", los decasílabos o impares riman en -é-o y los hexasílabos o pares en en -á-o:

\footnotetext{
"Escuchad mi amistoso consejo" decía un milano,

No he podido contrastar el uso de formas métricas semejantes. Desde luego, el romanticismo había experimentado combinaciones variadas de ritmos y medidas. Pero no cabe duda de que la fabulística de Fernández Baeza, todo un muestrario de posibilidades, es muy rica métricamente, a la altura, probablemente, de los fabulistas anteriormente mencionados en este ámbito, en el que era difícil que el berciano no emulara a quienes le precedieron. Anteriormente citamos la fábula "El perro rabioso" en la que alternan los estribillos "por fatalidad" y "por casualidad". Me parece indudable que algo tuvo que ver en el asunto una de las más célebres fábulas de Iriarte, "El burro flautista", que reitera un mismo estribillo: "Por casualidad". En otra fábula, concretamente en "El grabador y su auditorio", se evoca a Iriarte y su conocida pieza "El gato, el lagarto y el grillo", escrita para satirizar el "estilo retumbante", y cuya característica es la rima esdrújula de todos sus 36 versos endecasílabos pareados, todo 
un alarde en ese sentido. En "El grabador y su auditorio", Fernández Baeza quiere plasmar "la charla altisonante de un retórico" y comienza recordando los versos del fabulista canario: “QQue no resucitara en este día / Iriarte, aquel hombre tan científico / en copiar el lenguaje, cual sabía / de ciertos animales específicos”; pero, a falta de Iriarte, lo hará él con ironía, burla y sátira contra quien defiende la tiranía de los Reyes, aunque aparentemente se oponga a ella. En la moraleja vuelve a nombrar al fabulista canario: “¿No encontráis en verdad en este prólogo, / los hombres que Iriarte pintó crítico, / del grillo y del lagarto en el apólogo, / no pensando en hablar como político?". Lo interesante, para nosotros, es la imitación métrica, pues en los servestesios de Fernández Baeza todos los versos pares tienen terminación esdrújula: “ «De la mar imitad el alzamiento, / vino a decir el orador lunático: / No sufráis dictaduras ni un momento» / Con todo el dictador aplaude enfático!". Como en Iriarte, lo raro e hiperbólico de la rima esdrújula contribuye a la burla ridiculizadora del "orador altísono pindárico".

En resumen, si no hay novedades métricas, sí hay cierta ostentación de una variedad con la que Fernández Baeza proporciona un buen muestrario de la mayor parte de las combinaciones rítmicas que un poeta de su siglo podía practicar.

\section{BIBLIOGRAFÍA}

Carnicer, R. (1984): “Un jurista ponferradino. Pascual Fernández Baeza”, Fiestas de la Encina (Ponferrada), 1984, 13 (incluido en Del Bierzo y su gente, Valladolid, Junta de Castilla y León, 1986, 55-56).

David Kossoff, A. et alii (coords.) (1986): Actas del VIII Congreso de la Asociación Internacional de Hispanistas I, Madrid, Istmo.

Domínguez Caparrós, J. (1999): Diccionario de métrica española, Madrid, Alianza Editorial.

Fernández Baeza, P. (1852): Colección de las fábulas políticas y morales, Madrid, Imprenta a cargo de C. González.

Fernández Baeza, P. (1853): Colección de fábulas morales, $2^{a}$ edición aumentada, Madrid, Imprenta a cargo de C. González.

Fernández Baeza, P. (1854): A Fabio. Epístola satírica en que se describen los vicios políticos y morales de la Corte, Ponferrada, Imprenta de Joaquín León Suárez.

Fernández Baeza, P. (1858): Nueva colección de las fábulas políticas y morales, tomo I, Madrid, Imprenta de M. Campo-Redondo.

Fernández Baeza, P. (1858): Nueva colección de fábulas morales, tomo II, $3^{\text {a }}$ edición aumentada, Madrid, Imprenta y Estereotipia de M. Rivadeneyra.

García Castañeda, S. (1986): “La fábula política española en el siglo XIX”, en A. David Kossoff et alii (coords.) (1986): 567-575. 
García, M. J. (2008): Pascual Fernández Baeza, León, Fundación Pedro Álvarez Osorio / Ayuntamiento de Ponferrada.

Martínez García, F. (1982): Historia de la Literatura Leonesa, León, Everest.

Navarro Tomás, T. (1974): Métrica española. Reseña histórica y descriptiva, $4^{\mathrm{a}}$ ed., Madrid, Guadarrama-Labor.

Navas Ruiz, R (1973): “Introducción” a J. E. Harzenbusch, Fábulas, Madrid, EspasaCalpe, Clásicos Castellanos, VII-XXV.

Ozaeta, Mª R., “Los fabulistas españoles (con especial referencia a los siglos XVIII y XIX)", http://213.0.4.19/servlet/SirveObras/01477398655704417654480/ p0000001.htm?mar... (Consultado en diciembre de 2012).

Prieto de Paula, Á. L. (1992): “Introducción” a T. de Iriarte, Fábula literarias, Madrid, Cátedra, 11-100.

Sainz de Robles, F. C. (1964): Fabulario español, Madrid, Espasa-Calpe (Austral).

Sebold, R. P. (1995): Historia de la literatura española. Siglo XVIII, 6, en G. Carnero (coord.), Madrid, Espasa-Calpe.

Sotelo, A. I. (2000): “Introducción” a F. M. Samaniego, Fábulas, Madrid, Cátedra, 13-142. 



\title{
EL USO DIDÁCTICO DE LA FÁBULA EN LA LITERATURA RENACENTISTA ALEMANA
}

JUAN LUIS MONREAL PÉREZ

Facultad de Educación. Universidad de Murcia ${ }^{1}$

\begin{abstract}
Resumen
El presente artículo examina, en el contexto del Humanismo renacentista europeo, el uso de la fábula en la Alemania renacentista y, más concretamente, la utilización de la misma por parte de humanistas renacentistas alemanes como Lutero y Melanchton. Estos reformadores alemanes vieron la utilidad didáctica de la fábula como medio para acceder al conocimiento general de la lengua y para adquirir sentido crítico en la vida. Igualmente consideraron que la fábula, en cuanto género literario, era un instrumento eficaz para el aprendizaje escolar. El interés de acercar los textos a los lectores les llevó a cultivar el género de los proverbios, los adagios, los refranes y la fábula con la finalidad de hacer el lenguaje accesible, cuestión que les era fundamental en su concepción de la lengua.
\end{abstract}

Palabras clave: Fábula, Proverbio, Refrán, Realidad, Ficción.

\begin{abstract}
This article analyzes the use of the fable in European Renaissance, specifically in German Renaissance Humanism, and it's used by Luther and Melanchton as members of this movement. They realized how useful they were didactically to enhance the access to general linguistic knowledge and a critical approach to the issues of their life. Moreover, they considered the literary form of the fable an effective instrument for the learning period. The will to approach texts to the reader made them deal with the literary form of proverbs, adagia, refrains and fables to bring language closer and more familiar, what was benchmark in their concept of language.
\end{abstract}

Key words: Fable, Proverb, Saying, Reality, Fiction.

\section{EL RENACIMIENTO ALEMÁN: REFORMA Y EDUCACIÓN}

El renacimiento alemán, en líneas generales, participa de la filosofía humanista que caracteriza a todo el renacimiento europeo. Ésta no es simplemente la vuelta a lo antiguo, al estudio de las letras y artes de Roma y Grecia, sino la actitud con que se realiza: el hombre es la base del pensamiento del Humanismo renacentista (Paris, 1962: 246, 252-253).

El Humanismo es, pues, un medio y un camino para conseguir el renacimiento de la

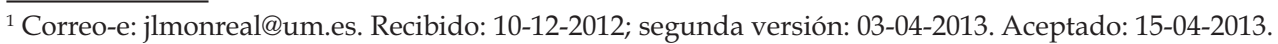


propia civilización. No es mera imitación de lo antiguo sino reelaboración a partir de su propia situación histórica y cultural (Mourelle de Lema, 1993: 85).

Considerando lo señalado anteriormente, se puede indicar que los términos Renacimiento y Humanismo están marcados por un carácter histórico y por una filosofía de renovación del hombre que busca su armonía con el universo natural (Ortega, 2002: 18).

En Alemania, tal como sucedió en los países europeos más impregnados del Humanismo renacentista, en los tres primeros decenios del siglo XVI se produjo un clima muy favorable hacia todo lo que suponía renovación, nuevos valores y recuperación de la cultura antigua a través del acceso a los estudios profanos, principalmente, los clásicos (Monreal, 2012: 191). Los humanistas en Alemania, al igual que sucedió también en otros países europeos (Vidal, 2008: 32-37), formaron un colectivo creciente, ávido de cambios y muy sensible a verse atraído hacia aquellos personajes que se pusieron a la cabeza de lo que representaban los valores más significativos del Humanismo renacentista, como es el caso de Lutero y Erasmo (Lilje, 1986: 39).

Los humanistas alemanes vieron en Lutero, más que un líder de la religión y la teología. Lo que identificaron en él fue un gran defensor de aquellos valores humanistas, considerados como elementos de regeneración de la vieja sociedad, tales como la estima por los estudios profanos clásicos, el rechazo de la literatura basada en la teología especulativa y la necesidad de una nueva enseñanza que conllevara un cambio fundamental en la organización escolar (Grane, 1975: 108-110).

En la reforma de la enseñanza y en la nueva organización escolar que emprende la reforma protestante, Lutero se auxilia para tal misión de su amigo y estrecho colaborador como fue Melanchton, puesto que ambos coincidían en la necesaria reforma que había que llevar a cabo, independientemente de que en algunas cuestiones fundamentales disintieran. Ambos jugaron en la cuestión de la enseñanza un papel importante y cada uno con una función distinta: Lutero, por su parte, como inspirador de la reforma y, Melanchton, como el ejecutor. Lutero, en este campo de la educación, por puro pragmatismo, muestra su cara de humanista (Egido, 2006: 27).

Sin embargo, las expectativas que los humanistas alemanes depositaron en Lutero como hombre humanista, pronto se fueron desvaneciendo, a medida que el monje alemán se fue radicalizando en la cuestión religiosa y teológica y se produjera en Alemania la revolución religiosa. Ello supuso el desplazamiento del interés por el proyecto de la reforma humanista y la entrada del conflicto religioso que consumó la Reforma Protestante. Esta situación hizo que el florecimiento humanista alemán se viera truncado y no lograra consolidar algunas de las reformas que anunciaba, sobre todo en lo relativo a la enseñanza (Jansen, 1925: Parte Segunda, 179). 


\section{USO DE RECURSOS LITERARIOS EN EL RENACIMIENTO EUROPEO.}

Para los humanistas renacentistas europeos era muy importante hacer accesible el conocimiento antiguo y real al pueblo a través del uso del lenguaje, independientemente de la lengua utilizada, fuera el latín o una lengua vernácula. La accesibilidad al conocimiento no era incompatible con el rigor del mismo; a tal fin, se usaban la fábula, el proverbio, el refrán, y se recurría en los libros denominados misceláneas y florilegios al uso de citas, modismos, sentencias, anécdotas, exempla y otras flores de erudición clásica que servían a la par de alimento para el espíritu y de pábulo para la composición literaria, y ello con el objetivo de poner al alcance del lector el saber del mundo antiguo (Serrano, 1992: 49).

Aparte de la fábula ${ }^{2}$ como recurso literario que utilizaron los humanistas renacentistas europeos, entre los que están Lutero y Melanchton, también se usaron otros recursos literarios, como el proverbio y el refrán, tal como hicieron Erasmo, Juan de Valdés y Sebastián Franck. Entre estos tres recursos literarios hay estrecha relación y todos ellos forman parte del contenido de los libros llamados misceláneas y florilegios. Atendiendo a dichos usos, se examinan, previamente, las aportaciones de Erasmo, Valdés y Franck, relevantes humanistas europeos, al proverbio (adagia) y al refrán, antes de centrarnos en la fábula con Lutero y Melanchton.

El primero, Erasmo, incorporó proverbios en su obra Adagia (1500), y en la que la fábula es una parte de la misma; y el segundo, Valdés, usó los refranes en su obra Diálogo de la lengua (1535). En ambas situaciones, sus aportaciones literarias tienen carácter didáctico y se trata, en el caso de Erasmo, de una colección de proverbios que reflejan la sabiduría del mundo clásico antiguo; y, en el caso de Juan de Valdés, con sus refranes antiguos castellanos, busca poner en valor la lengua real.

Erasmo transita por el mundo clásico no de forma superficial y resultado de este camino es la obra Adagia, orientada a exaltar la cultura humanista de las letras y escrita para fomentar el pensamiento y la lengua latina.

Un rasgo de Erasmo a resaltar, en su condición de filólogo, es el esfuerzo que hizo en toda su obra y, particularmente en sus Adagia, para hacerla accesible y comprensible a todos. La orientación didáctica de esta obra constituyó un objetivo importante, siguiendo en éste como en otros aspectos la línea del humanismo. Esto explica que alcanzara en Europa un considerable éxito y fuera una de las obras más leídas por parte de los estudiosos de la latinidad.

Erasmo al referirse a la fábula en los Adagia, utiliza los términos latinos fabula, fabella y apologus, asignándole al primero de ellos, fabula, los mismos referentes que poseía en la literatura latina. Además, la inclusión que Erasmo hace de la fábula en la

\footnotetext{
${ }^{2}$ No es objetivo de este artículo analizar este género literario, sino el uso que del mismo se ha hecho en un periodo histórico-cultural determinado como es en el Renacimiento alemán. En cualquier caso, sí queremos señalar que con la denominación fabula, a lo largo de la historia de este género literario se han abordado otras composiciones y sentidos literarios próximos (Talavera, 2007: 30-31); ello explica que la fábula sea "un género popular y tradicional, esencialmente 'abierto', que vive en infinitas variantes" (Rodríguez Adrados, 1979: 11).
} 
colección de proverbios que contiene la obra Adagia, se explica por la relación que desde antiguo se establecía entre fábula y proverbio y que la tradición humanista reforzó aún más. Tan estrecha es la vinculación entre estos dos términos que la fábula puede expresarse en un proverbio en forma de moraleja; y, a su vez, éste puede generar una fábula (Serrano, 1992: 50-54).

El segundo, Juan de Valdés, recoge también la tradición renacentista que relaciona proverbios y refranes y, a su vez éstos con las fábulas esópicas. Con este legado de géneros literarios, Valdés propone en su obra Diálogo de la lengua el uso de los refranes antiguos, como verdadero patrimonio de la lengua real, ante la falta de buenas obras y autores que marquen la dirección de la perfección en la lengua castellana. Los refranes, en su opinión, aunque nacidos del vulgo, sin embargo son testimonio del uso auténtico y generalizado de ciertas formas léxicas y sintácticas (Barbolani, 2006: 71).

El recurso a los refranes que presenta Valdés como medio de mejorar la lengua, no cabe duda que es una clara alternativa a la búsqueda de la perfección de la lengua por la vía del latinismo y cultismo. (Valdés, 1997: 246-247).

Con la utilización del recurso de los refranes, Valdés es consciente de que entronca con toda una tradición literaria de orientación concreta y real, que tanto en el pasado, época medieval, como en el presente, había tenido su éxito y eficacia en el desarrollo de la lengua española en términos concretos y, en términos generales, había enriquecido la lengua como instrumento de comunicación, tal como Erasmo hizo en sus Adagia (Lapesa, 1974: 15).

En suma, lo que se manifiesta en Valdés a través de su amor y aprecio de los refranes es la atracción que siente por la lengua popular. En ella ve la sobriedad del estilo y la nitidez en la expresión, que no son más que rasgos naturales de la perfección de la lengua (Valdés, 2011: 162).

Por último, Sebastián Franck, humanista alemán (1499-1542), vivió como los de su generación, entre el ambiente que dominaba a finales de la Edad Media, el escolasticismo, y la influencia del humanismo que sentaba las bases de la nueva cultura. Su aportación, desde el territorio alemán, al recurso literario de los proverbios ha sido significativa, con la publicación de una colección de proverbios (Sprichwörter) en 1541 en Frankfurt (Franck:1541); ésta fue reimpresa varias veces con variaciones y logró tener amplia aceptación, precisamente por el carácter popular que Franck le dio a esta obra (Cáceres y Martín-Gaitero, 1994:101).

En la contribución de Franck al género de los proverbios, se recoge la tradición medieval alemana en este campo, pero también es manifiesta la influencia de otros humanistas europeos en esta obra, como la de Vives y sobre todo la de Erasmo:

[...] ya que no cree necesario citar el nombre de Erasmo, pues, [...] no hay refrán traducido del latín que no haya sido tomado de los 4.150 Adagia señalados y comentados anteriormente por Erasmo (Gilly, 2005:272).

Conviene señalar, finalmente, que la aportación literaria de Franck a través de su colección de proverbios, aún siendo importante, ha quedado relegada a un segundo 
plano, por haber ocupado un primer plano su controvertida posición teológica, su radical crítica a la Iglesia institucional, incluida a la reformada (Koyré, 1981:36), y sus otras obras como Chronica y Paradoxa, de carácter teológico-religioso, que produjeron fuertes reacciones entre los responsables de las iglesias y entre los líderes del pensamiento teológico-religioso del momento.

\section{USO DE LA FÁBULA COMO RECURSO LITERARIO EN EL RENACIMIEN- TO ALEMÁN}

La fábula es otro relevante recurso literario utilizado en los llamados libros misceláneas y florilegios y muy utilizado por la literatura renacentista alemana. El término del alemán antiguo (Mittelhochdeutsch) 'fabele', proviene del latín 'fabula' y fue calificado por Phaedrus como un género literario (Fabulae Aesopicae). Las Fábulas de Esopo fueron traducidas al alemán por el humanista alemán Heinrich Steinhöwel (1412-1482), y cuya fama ha estado siempre relacionada con la traducción de dicha obra. La primera traducción de las Fábulas de Esopo la hizo en latín-alemán, en la versión titulada "Ulmer Aesop" y publicada por primera vez en 1476 en Ulm. En los años siguientes, Steinhöwel continuó traduciendo las Fábulas de Esopo, así como otras obras significativas, como algunas de Petrarca y Boccaccio, lo que hizo que sus trabajos fueran conocidos en Europa; ello contribuyó a su reconocimiento como relevante humanista alemán, muy inspirado por el Renacimiento italiano y dotado de una sólida y diversa formación ${ }^{3}$.

El proceso de incorporación de la fábula a la literatura alemana toma cuerpo en la Edad Media en el ámbito germánico; en esta época ya existía una rica tradición en este género (Dicke y Grubmüller:1987) y se le asignaba también una función (Grubmüller:1977). Desde estos antecedentes y bajo esta influencia se explica la posterior contribución de Steinhöwel a la Fábula. Ya en este tiempo este género literario se expresaba por los términos bîspel o bîshaf, que en alemán moderno equivalen al término ejemplo. Ambos términos muestran, que se trata de una narración educativa. La palabra bîspel indica la relación entre fábula, parábola y refrán. Se refiere a una narración que no se representa a sí misma, sino que representa otra cosa, cuyo sentido no reside en lo que se cuenta. Al respecto Reinhard Dithmar señala que "concretamente, en el siglo XIII se despreció el término spel pasando a ser lo que no tiene ningún significado implícito o incluso una narración descabellada, mientras que bîspel muestra lo verdadero, bajo el envoltorio de lo que entretiene. También las parábolas y alegorías bíblicas se denominan bîspel [...]. En la Literarura Medieval se denominan las fábulas de Esopo como bîspel (Dithmar, 1988: 163) .

\footnotetext{
${ }^{3}$ Tiene interés al respecto el artículo de G. Dicke sobre el Esopo de H. Steinhöwels. Lo califica de interés universal y de muy comprensible para la prosa alemana (Dicke:1994).

${ }^{4}$ La traducción de la cita ha sido realizada por el autor del artículo, cuyo texto en el original alemán es el siguiente: Bereits im 13. Jahrhundert wird der Begriff spel (Erzählung, Bericht) abgewertet zur nicht verbürgten und somit unwahren oder sogar lügenhaften Erzählung, während bîspel als die -von einer unterhaltsamen Hülle umgeben- Wahrheit erscheint. Auch das biblische Gleichnis wird bîspel genannt [...]. In der mittelalterlichen Spruchdichtung werden die äsopischen Fabeln als bîspel bezeichnet.
} 
La larga tradición de la fábula en Alemania y el interés por su valor educativo en épocas donde había una gran preocupación social por la tradición cultural hace que analicemos este género literario a través del uso que hizo del mismo Lutero.

\section{EL USO DE LA FÁBULA COMO GÉNERO LITERARIO POR LUTERO Y MELANCHTON}

Lutero entendió perfectamente que el éxito de su mensaje, oral y escrito, residía en hacer de la lengua y del lenguaje un verdadero instrumento de comunicación con sus oyentes y lectores, a través de las formas literarias convenientes para convertirlo en atractivo.

Un ejemplo de la calidad del lenguaje empleado por Lutero se ve reflejado en sus Charlas de Sobremesa o las Tischreden, en alemán, y cuya edición fue tardía. Éstas recogen una temática muy variada sobre distintas cuestiones de la vida de Lutero y que fueron recordadas por éste ante los comensales que formaban un círculo familiar reducido.

El valor de estos textos, las Tischreden, es considerable y reflejan bien el uso del lenguaje por parte de Lutero. El hecho de que éstos no fueran escritos directamente por él no le restan valor, ya que los copistas de los textos -como señala Egido-,

[...] los transcribieron con mimo. Por eso, en las ediciones críticas, se pueden contrastar las lagunas y defectos de sus notas apresuradas. Pero también gracias a su cuidado se puede gozar de estos dichos, expresados en estilo tan de Lutero, es decir, con trazos que a veces rayan en lirismo y en otras -muchas- ocasiones se recrean en resortes del peor gusto, con la inevitable apoyatura en las referencias sexuales (Egido, 2006: 426).

Este interés de acercar los textos a los lectores le llevó a Lutero a cultivar el género de los proverbios, los adagios, los refranes y la fábula con la finalidad de hacer el lenguaje accesible, cuestión que le era fundamental en su concepción de la lengua.

La fábula, entre estos recursos literarios, era para Lutero muy apreciado, sobre todo porque le veía una gran utilidad didáctica, como más adelante se indicará. Su interés por este género literario le llevó a conocerlo bien y a familiarizarse con el mismo. Por ello, sintió una gran admiración por Esopo, valorando sus escritos considerablemente, traduciendo sus fábulas que, por otra parte, le sirvieron de referente en sus obras.

Prueba de la valoración que hacen, tanto Lutero como Melanchthon, de la utilidad de la fabula, como recurso didáctico, es su propuesta de utilizar las fábulas de Esopo en la nueva orientación de la enseñanza que propone la reforma protestante. Al respecto, es ilustrativo el siguiente fragmento:

Así, según lo establecen las Instrucciones para los Visitadores de las Escuelas Parroquiales ('Unterricht der Visitatoren an die Pfarherrn im Churfürstenthumb zu Sachsen') -documento escrito conjuntamente por Lutero y Melanchthon en 1528 con el fin de normar el funcionamiento de estas escuelas-, la educación básica debía constar de tres etapas. En la primera de ellas los niños aprenderían a leer y escribir en latín, enriquecerían su vocabulario y se les dictaría los primeros rudimentos de gramática. La segunda etapa estaría dedicada por completo a la gramática y a las primeras lecturas de obras de autores clásicos (como, por ejemplo, las fábulas de Esopo). 
Finalmente, en la tercera etapa se les daría a los estudiantes obras de autores como Virgilio, Ovidio, Cicerón y se les introduciría al estudio de la lógica y de la retórica. (Suárez, 2003: 22).

Fruto del interés de Lutero por la fábula como género literario, es su traducción de las fábulas de Esopo; para dicho trabajo se apoyó en textos alemanes preexistentes, además de tener en cuenta también otras obras escritas en latín.

En cuanto al uso que Lutero hizo de la fábula, éste siguió la tradición renacentista al respecto, utilizándolas para facilitar la lectura y divulgar las moralejas contenidas en las mismas. Aparte de esta función didáctica general, Lutero utiliza este recurso literario para criticar las conductas de los papistas, de determinados personajes políticos y religiosos, de determinados sectores de la sociedad de su tiempo, mediante expresiones relacionadas con animales sacados de las fábulas de Esopo. Con este uso, Lutero reproduce la práctica habitual de este género literario que ejemplifica modelos morales, tanto para resaltar las virtudes del ser humano como para criticar las miserias de las conductas, por ser desacertadas y censurables (Abraham et al., 2009: 124).

No faltan fragmentos en las obras de Lutero en los que hace crítica de diferentes situaciones $\mathrm{y}$, a tal fin, utiliza moralejas derivadas y relacionadas con el género de las fábulas. A modo de ejemplo, presentamos algunos fragmentos de obras de Lutero, que testimonian el objetivo y la finalidad de este recurso literario: ${ }^{5}$

1. Obra: 'La libertad del cristiano' (Von der Freiheit eines Christenmenschen, 1920).

Más que obra, podría decirse obrilla o tratadillo. Pertenece a los escritos de reforma y se caracteriza por cierta orientación mística.

Lutero plantea en este fragmento el problema de la justificación, tema central de su teología, en los siguientes términos y, precisamente es en ese contexto en el que recurre a las fábulas 1 y 4 de Fedro:

Honor tal lo consigue el cristiano por la fe solo, no por obras. Bien claro se ve por lo dicho cómo el cristiano está libre de todo, está sobre todas las cosas; por lo mismo no tiene precisión de recurrir al concurso de ninguna buena obra para su justificación y salvación: la fe se lo otorga todo sobreabundantemente. Si fuese tan necio como para pensar que puede conseguir la santidad, la libertad por una obra buena, perdería la fe y todo lo demás: le pasaría exactamente igual que al perro que llevaba una tajada de carne en las fauces: quiso atrapar la carne que se reflejaba en el agua y se quedó sin la carne y sin su reflejo (Lutero, 2006: 163).

2. Obra: 'A los magistrados de todas las ciudades alemanas, para que construyan y mantengan escuelas cristianas' (An die Radsherrn aller Stedte deutsches Lands: Das sie Christliche Schulen auffrichten und hallten sollen, 1523). También en este caso es una pequeña obra. Se trata de un alegato en favor de la educación, que constituyó un pilar fundamental de su reforma.

En el siguiente fragmento, Lutero al hacer una fuerte crítica en relación a la mala enseñanza del latín por culpa de profesores ignorantes, incorpora la correspondiente moraleja, como parte de la fábula:

\footnotetext{
${ }^{5}$ Está marcado con cursiva, la parte del texto que corresponde a dicho genero literario.
} 


\begin{abstract}
¿No ha sido una lamentable calamidad lo sucedido hasta ahora, cuando un muchacho tenía que emplear veinte años o más para aprender un latín tan deleznable, sólo para hacerse cura o leer la misa $[. .$.$] ¿Quién es el culpable de lo ocurrido? No había más libros que los necios$ frailes y «sofistas». ¿Qué otra cosa podía salir que discípulos y maestros zafios, como zafios eran los libros en los que tenían que estudiar? Un grajo no puede criar palomas ni un loco personas inteligentes (Lutero, 2006: 163).
\end{abstract}

\title{
3. Obra: 'Del arte de traducir' (Sendbrief vom Dolmetschen, 1530).
}

Esta obra es realizada bajo la forma literaria de epístola y enviada a su amigo Wenceslao Link; en ella transmite su pensamiento acerca de la traducción y de la exégesis. El origen de la obra reside en la polémica que Lutero mantuvo con los papistas a propósito de haber añadido 'sólo por la fe', a su traducción del texto de la Biblia Arbitramur hominen justificari ex fide absque operibus, ya que así, dice Lutero, la lengua resulta más ingeniosa y armoniosa con la lengua alemana. Resultado de la fuerte agresividad de Lutero ante esta situación, es el uso frecuente en esta obra de moralejas, nuevamente vinculadas a fábulas. Veamos dos ejemplos:

Si alguna falta he cometido (de lo que no tengo conciencia, puesto que a sabiendas ni una letra he traducido de forma inexacta) a lo que no estoy dispuesto es a tolerar que los papistas se constituyan en jueces sobre ello: sus «ija-ija» son demasiado flojos para juzgar mis traducciones. Sé muy bien el arte, la entrega, el sentido común y la inteligencia que requiere el buen traducir: de esto saben menos ellos que el asno del molinero, puesto que nunca han puesto mano a la obra (Lutero, 2006: 308).

Estoy decidido a seguir despreciándolos mientras sigan siendo gente (quiero decir borricos) de esta calaña. Porque entre ellos hay insolentes tan descarados como el doctor Schmidt, el doctor Rotzlöffel y similares, que jamás han aprendido su propia ciencia, es decir, la ciencia de los sofistas, y sin embargo, se lanzan contra mí en estas cosas que no sólo superan toda sofistería, sino que también (como dice San Pablo) se encuentran muy por encima de toda la sabiduría del mundo y de la razón. No tiene que esforzarse el asno por cantar, porque por las orejas se le distingue inmediatamente (Lutero, 2006: 310).

En la historia de la formación de la fábula están presentes, tanto elementos reales como simbólicos o ficcionales de la sociedad. A la parte ficcional "se le supone el camuflage o extravío del sentido que encierra" (Certeau, 2006: 21). La presencia de estos dos elementos, por una parte, puede crear confusión a veces y, por otra, puede requerir en determinadas expresiones, interpretación de lo que realmente quiere significar.

Esta doble significación -género literario y expresión de la ficción literaria o discurso irreal- "ha conducido, en opinión de Dithmar, hasta nuestro siglo a malentendidos, a causa de los cuales las fábulas de Esopo sufrieron injustamente el descrédito"6 (Dithmar, 1988: 164).

Lutero superó la confusión entre el concepto del género de la fábula y el de la creación ficcional, al aunar crítica de la realidad y valor didáctico de ese género

\footnotetext{
${ }^{6}$ La traducción de la cita ha sido realizada por el autor del artículo, cuyo texto en el original alemán es el siguiente "Diese Doppelbedeutung -Gattungsbezeichnung und Ausdruck für erdichtete, unwahre Rede- hat bis unser Jahrhundert immer wieder zu Mißverständnissen geführt, durch welche die äsopische Fabel zu unrecht in Mi $\beta$ kredit geriet".
} 
literario. Sin embargo, es una confusión injustificada ya que en ambos casos se critica la realidad. Al respecto, de nuevo señala Rheinhard Dithmar:

\begin{abstract}
En conclusión fábula y realidad no tienen por qué contraponerse y Lutero lo tuvo en cuenta para que su traducción de la Biblia fuera didácticamente efectiva. Así, en la traducción luterana de la Septuagésima, la palabra griega 'mythos' se tradujo por el término 'fabula', cuando se trata de la narración moralizante de dicho texto bíblico (Dithmar, 1988: 164). En relación a lo anterior, Reinhard Dithmar menciona el resultado al que llegó Adolf Jülicher en su monumental obra Die Gleichnisreden Jesu, cuando dice que "de hecho, pertenece a la esencia de la fábula, el que actualice un suceso pasado y acabado, el que comunique la realidad del mito"7 (Jülicher, 1976: 98).
\end{abstract}

\title{
5. LA INFLUENCIA DE ESOPO EN EL USO DE LA FÁBULA POR LUTERO.
}

Esopo gozaba de una gran influencia en la sociedad de la época, gracias a la cobertura que le daban las fábulas. Para Lutero, Esopo era mucho más que el creador de las fábulas. Representaba, por una parte, el modelo de crítica a la sociedad de la época y, por otra, era el autor de fábulas con las que educar a niños en la verdad y el amor al arte. Fue lo mismo que realizó Heinrich Heine con su Wintermärchen para criticar la sociedad alemana sin ser censurado.

Precisamente, debido a la admiración que Lutero sentía por Esopo, se fijó el objetivo de depurar la traducción de las Fábulas de Esopo que hizo Steinhöwel, lo que le llevaría a publicar un libro que contuviera aquellas fábulas más esenciales y útiles, y que estuvieran al nivel de la fe religiosa, aunque hicieran reír. Por esto se ha dicho que Lutero "quiere completar su propio Esopo, el Esopo puro, que recomienda a todos los corazones piadosos en lugar del Esopo alemán y pecaminoso, con una Vita Esopi" 8 (Dithmar, 1988: 39). El libro apareció por primera vez en 1557, en el quinto volumen de su edición de Jena, con el título Las fábulas completas de Esopo, vertidas al Alemán por DML, con una cuidada introducción para el uso y satisfacción de dicho libro por toda persona de cada estamento, para que lo lean con deleite y aprovechamiento.

No cabe duda, pues, de la importancia del significado político de la figura de Esopo ni de su utilización con fines religiosos. Sin embargo, Lutero concibió estos objetivos con ambición tal que deseó que ese libro fuera leído por todos los miembros de la sociedad.

\section{INFLUENCIA DE LA FÁBULA EN LA LABOR TRADUCTORA DE LUTERO}

El interés que la fábula despertó en Lutero se vio reflejado en su labor de traducción. Su búsqueda por la sencillez del lenguaje y que fuera accesible al pueblo

\footnotetext{
${ }^{7}$ La traducción de la cita la ha sido realizada por el autor del artículo, cuyo texto en el original alemán es el siguiente: "gehört es zum Wesen der Fabel, da $\beta$ sie Vergangenes, Vollendetes beibringt, da $\beta$ sie ihrem Mythus kuhn der Wirklichkeit zuteilt".

${ }^{8}$ La traducción de la cita la ha sido realizada por el autor del artículo, cuyo texto en el original alemán es el siguiente: "Denn er (Lutero) will seinen eigenen, den gereinigten Esopus, den er allen ‘frommen Herzen' an Stelle des 'Deudschen shändlichen Esopum' Steinhöwels empfielt, durch eine Vita Esopi ergänzen".
} 
le llevó a utilizar al máximo en la traducción aquellos géneros literarios que facilitaran dicho objetivo, entre los que está la fábula. La traducción de la Biblia a la lengua alemana será la ocasión.

Los dos criterios o principios que orientan la obra de traducción de Lutero son: no alejarse de la letra y al mismo tiempo prescindir de la materialidad de la letra (García Yebra, 1979: 25-26). Siguiendo estos dos criterios, Lutero es consciente de que las enseñanzas que abundan en la Biblia, al igual que en la fábula, no radican solo en lo que se dice ni en lo que está en el texto. Por ello Lutero señala que las traducciones no deben oscurecer el significado metafórico de las alegorías y parábolas, especialmente las de la Biblia; por eso "defiende sin ambajes, en los Sumarios sobre los salmos y causas de la traducción, que «no es el sentido que debe servir a las palabras sino las palabras al sentido»" (Brandenberger, 2002: 25).

Esta forma de entender Lutero la traducción le lleva a utilizar en su traducción bíblica un alemán cercano al hombre sencillo, que apelara a sus conocimientos previos y a su experiencia cotidiana y donde lo fabuloso, interesante y emocionante hiciera creíble el mito. En el siguiente fragmento de su obra El arte de traducir, Lutero deja traslucir perfectamente su forma de entender y de realizar el uso de la lengua, en este caso de la lengua alemana, para que todos le entiendan:

No hay que solicitar a estas letras latinas, cómo hay que hablar el alemán, que es lo que hacen esos borricos; a quienes hay que interrogar es a la madre en la casa, a los niños en la calle, al hombre corriente en el mercado, y deducir su forma de hablar fijándose en su boca. Después de haber hecho esto es cuando se puede traducir: será la única manera de que comprendan y de que se den cuenta de que se está hablando con ellos en alemán (Lutero, 2006: 311).

\section{LA FÁBULA Y SU USO DIDÁCTICO}

Lutero contribuyó a mostrar la utilidad didáctica de un género como la fábula que persigue como objetivo favorecer el conocimiento de la lengua y el sentido crítico, expresado mediante la moraleja de la fábula. Por ello, Lutero consideró las fábulas como un material didáctico útil para el aula, al facilitar el aprendizaje de la lengua, favorecer el desarrollo del sentido crítico en los alumnos y mostrar el valor moralizante de las conductas, como aparece en su obra Tischreden (Charlas de sobremesa) al relatar historias cortas de esta naturaleza, como anteriormente hizo Erasmo de Roterdam en sus Adagia.

Coherentemente con el valor que Lutero y Melanchton le atribuyen a la fábula por ser un buen instrumento didáctico para la educación de los alumnos, tienen muy en cuenta dicha estima, e incluyen la enseñanza de las fábulas de Esopo en el curriculum escolar de la escuela alemana reformada. No cabe duda que la cohabitación en la fábula de elementos reales y de ficción puede fomentar la creatividad en la escuela y favorece también la preparación para la vida real. Posiblemente éstos y el resto de aspectos señalados en el artículo, expliquen la pervivencia de este género a lo largo del tiempo (Rodríguez Adrados, 1979: 11). 


\section{CONCLUSIÓN}

El recurso a la fábula como género literario y su uso didáctico desde la perspectiva cultural de los renacentistas y reformistas alemanes, entre los que sobresalen Lutero y Melanchton, ha contribuido a comprender su valor educativo y a ser transmisora de la verdad de la vida. La necesidad de relacionar el mundo real y el mundo de la educación en el que se utilizan elementos simbólicos y ficticios para el aprendizaje, es intrínseco a la visión de la fábula, en general, y también a la visión luterana de la fábula.

\section{BIBLIOGRAFÍA}

Barbolani, C. (2006): “Introducción”, en J. de Valdés: Diálogo de la lengua, Madrid, Ediciones Cátedra.

Brandenberger, T. (2002): “Introducción”, en M. Lutero: Carta sobre el arte de traducir, Madrid, Caparrós Editores.

Cáceres, I. y Martín-Gaitero, R. (1994): “Los refranes flamencos de Pieter Bruegel", Revista Paremia, $\mathrm{n}^{\mathrm{o}} 3$.

Certeau, M. (2006): La fábula mística (siglos XVI-XVII), Madrid, Ediciones Siruela.

Dicke, G. (1994): Heinrich Steinhöwels Esopus und seiner Fortsetzer: Untersuchungen zu einem Bucherfolg der Frühdruckzeit, Tübingen, Niemeyer.

Dicke, G. y Grubmüller, K. (1987): Die Fabeln des Mittelalters und der FrèHeren Neuzeit. Ein Katalog der deutschen Versionen und ihrer lateinischen Entsprechungen, München, Fink.

Dithmar, R. (1988): Die Fabel, Padeborn, Ferdinand Schöningh.

Egido, T. (ed.) (2006): Lutero. Obras, Salamanca, Ediciones Sígueme.

Franck, S. (1541): Sprichwörter, Schöne, Weise, Herrliche, Clugreden, und Hoffspruch (reproducción de la ed. Frankfurt 1541, con un prefacio de Wolfgang Mieder), Hildescheim, Olms.

García Yebra, V. (1979): “Lutero, traductor y teórico de la traducción”, Revista Arbor, Tomo CII, no 399-Marzo: 23-34.

Gilly, C. (2005) : "Erasmo, la Reforma radical y los heterodoxos radicales españoles", en T. Martínez Romero (Editor): Les lletres hispaniques als segles XVI, XVII i XVIII, Castelló de la Plana, Publications de la Universitat Jaume I.

Grane, L. (1975): Modus Loquendi Theologicus. Luthers Kampf um die Erneuerung der Theologie (1515-1518), Leiden, E.J. Brill.

Grubmüller, K. (1977): Meister Aesopus. Untersuchungen zu Geschichte und Function im Mittelalter, Zürich-München, Artemis.

Janssen, J. (1925): “La cultura alemana antes y después de Lutero”, en Historia Universal, Vol. VIII bis, Barcelona, Librería Religiosa. 
Jülicher, A. (1976): Die Gleichnisreden Jesu. Zwei Teile in einen Band, Darmstadt (Impresión reprografiada de la edición de dos volúmenes, $2^{\text {a }}$ Edición, 1910).

Koyré, A. (1981): Místicos, Espirituales y Alquimistas del siglo XVI alemán, Madrid, Akal.

Lapesa, R. (1974): “Introducción” (Selección, estudio y notas), en J. de Valdés: Diálogo de la lengua, Zaragoza, Editorial Ebro.

Lilje, H. (1986): Lutero, Barcelona, Salvat Editores.

Lutero, M. (2006): Obras. Edición preparada por T. Egido, Salamanca, Ediciones Sígueme.

Monreal, J. L. (2011): “Juan de Valdés, humanista y lingüista”, Revista Cuadernos del Institu to Historia de la Lengua, 6: 141-173.

Monreal, J. L. (2012): “La perspectiva religiosa y el uso de la lengua en Lutero”, Revista Futhark, 7: 189-227.

Mourelle de Lema, M. (1993): “Fundamentos filosóficos del Humanismo de Vives”, en Juan Luis Vives, Madrid, Grugalma.

Ortega, A. (2002): Fray Luis de León, humanista, Salamanca, Editorial CEIAS.

Paris, C. (1962): “Vives y la formación del saber moderno", en Anales de la Cátedra Francisco Suarez, 2, Fasc. 2. Universidad de Granada: 235-264.

Rodríguez Adrados, F. (1979): Historia de la fábula greco-latina, Madrid, Editorial de la Universidad Complutense.

Serrano, A. (1992): “La fábula grecolatina en los Adagia de Erasmo y su influencia en el humanista Fernando de Arce", Revista Myrtia, 7: 49-80.

Suárez, R. T. (2003): “El sentido histórico del proyecto educativo de Lutero" (I), Revista Frónesis, Vol. 10, 3: 1-31.

http:/ / www.revistas.luz.edu.ve/index.php/frone/article/view/63

(Consultado en noviembre de 2012).

Talavera, S. (2007): La fábula esópica en España en el siglo XVIII, Cuenca, Ediciones de la Universidad Castilla-La Mancha.

Valdés, J. (1997): “Diálogo de la lengua”, en Obras Completas, I. Diálogos, Escritos espirituales. Cartas, Madrid, Ediciones de la Fundación José Antonio de Castro. 


\title{
UNA SELECCIÓN DE FÁBULAS DE ESOPO Y DE LA POSTERIOR TRADICIÓN ESPAÑOLA: ANÁLISIS Y POSIBILIDADES DIDÁCTICAS DE LAS MISMAS EN LAS AULAS DE EDUCACIÓN PRIMARIA
}

\author{
ANDRÉS MONTANER BUENO
}

Universidad de Murcia $^{1}$

\begin{abstract}
Resumen
En la presente investigación es nuestro objetivo llevar a cabo un análisis de las fábulas de Esopo, y de las de algunos fabulistas de la tradición esópica española, los cuales han contribuido a crear y a conformar toda una serie de estereotipos culturales y sociales, en torno a los que se ha configurado un discurso que legitima y favorece la ideología de las clases de mayor poder de la sociedad occidental. Sirviéndonos de sus composiciones, las emplearemos en las clases de Educación Primaria como recurso para desarrollar en el alumnado las competencias sociocultural e intercultural. En este sentido, proponemos algunas cuestiones dirigidas a que los estudiantes reconozcan y acepten el pluralismo social y racial como una realidad positiva propia de nuestro siglo.
\end{abstract}

Palabras clave: Fábulas Esopo, estudios culturales, tradición fabulística española, didáctica de la literatura, educación en valores.

\begin{abstract}
The purpose of this research is to analyze the Aesop's fables, and some Aesopian Spanish fabulists, which have helped to create and shape a range of cultural and social stereotypes, around which set a discourse that legitimates and promotes the ideology of the most powerful classes of Western society. Using these compositions, we will employ them in Elementary Education classes as a resource for students to develop skills in sociocultural and intercultural. Thereby, we propose some questions addressed to students to recognize and accept social and racial pluralism as a positive reality of our own century.
\end{abstract} Keywords: Aesop's Fables, cultural studies, Spanish fabulistic tradition, didactic literature, values education.

\section{INTRODUCCIÓN}

Teniendo en cuenta que un género como la fábula ha llegado hasta nuestros días habiendo nacido aproximadamente en el siglo VI a. C., esto es, cuenta con una vida de más de veintiséis siglos, se comprenderá en seguida la importancia que un tema

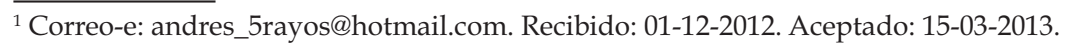


como éste puede suscitar en el investigador literario. A este propósito vamos a enfocar nuestra comunicación sobre la fábula en dos sentidos muy diferentes. El primero de ellos será puramente literario y lo dedicaremos a reflexionar teóricamente sobre la fábula como manifestación literaria y sobre Esopo como primer autor occidental al que se le atribuyen este tipo de creaciones. A partir de él iremos trazando muy sucintamente un recorrido por la transmisión de su fabulística a otros autores europeos, para terminar subrayando la importancia que tuvo en la tradición española de los siglos XVIII y XIX, contando con la presencia de autores tan destacados como Tomás de Iriarte, Félix María de Samaniego, Ramón de Campoamor o Juan Eugenio de Hartzenbusch. El segundo irá más relacionado al desarrollo de una propuesta educativa mediante el empleo de fábulas en las aulas de Educación Primaria. Así, partiendo de los estereotipos negativos que aparecen en algunas fábulas esópicas y que son recogidos, en mayor o menor medida por los autores españoles anteriormente mencionados, tratamos de ofrecer una serie de cuestiones que se refieren a ámbitos controvertidos y que se plantean enfocados a la educación en valores a través del debate en las aulas.

\section{LA FÁBULA COMO MANIFESTACIÓN LITERARIA}

En este apartado que comenzamos es nuestro objetivo estudiar cuatro aspectos que se relacionan con la fábula como manifestación literaria, la cual ha llegado hasta nuestros días de muy diversas maneras. En primer lugar, vamos a centrarnos en qué es lo que la crítica literaria entiende por fábula, en segundo lugar, investigaremos acerca de sus orígenes, en tercer lugar, de qué manera se han presentado sus tipos argumentales a lo largo de la historia literaria y su relación con otros textos literarios $\mathrm{y}$, en último lugar, el valor que tienen los personajes que aparecen en ellas. Todo ello se hará teniendo en cuenta asimismo la continuidad esencial del mundo cultural fabulístico en Occidente, en distintas épocas y lugares.

Comenzando por ofrecer una definición de fábula, vamos a adscribirnos a la ofrecida por López Casildo (2011: 7) quien señala que la misma es "una composición literaria, en prosa o en verso, en que, mediante una ficción de tipo alegórico y la personificación de animales irracionales, objetos inanimados o ideas abstractas, se intenta dar una enseñanza práctica, a veces incluso con la intervención de personajes humanos y divinos". Se trata de una composición de carácter ejemplar, formada por un relato, generalmente breve, al que sigue un consejo moral o regla de comportamiento (moraleja) dirigida a enseñar un principio general de conducta, presentando un modelo específico de comportamiento. La cuestión controvertida está, como veremos más adelante, en que a la hora de fijar el ejemplo de conducta influyó, sin duda, el pensamiento del poder gobernante de cada época, con sus intereses particulares e ideológicos. Este hecho hizo de la moraleja, en ocasiones, un fijador de estereotipos negativos que, por la razón de venir argüido por una autoridad literaria, fue asumido por las personas que leían o escuchaban la misma.

Con respecto a los orígenes de la fábula, hemos de señalar que se trata de un asunto muy controvertido ya que durante mucho tiempo la crítica ha especulado sobre 
el mismo, en un intento de averiguar si procedía originariamente de Grecia o de la India y cuál de las dos tradiciones había tenido influencia sobre la otra. No obstante, con el descubrimiento de la existencia de fábulas asirias ha quedado demostrado que la fabulística más antigua tiene su origen en Mesopotamia. Desde esta zona habría llegado a Grecia a través del Asia Menor y por otra parte a India a través de Persia. De otro lado, por lo que respecta a la primera fábulística occidental, ésta tuvo su origen en Grecia considerándose tradicionalmente que el creador de la fábula griega fue un personaje enigmático llamado Esopo (siglo VI a. C.). A él se han atribuido toda una serie de fábulas que, en realidad vendrían a ser anónimas y pertenecerían a un género tradicional cuya difusión se llevó a cabo de forma oral.

Abordando ahora la cuestión acerca de la manera en que las fábulas se organizan de acuerdo a su disposición interna argumental, podemos clasificar las mismas en tres tipos diferentes. El primero de ellos sería el de confrontación o agonal en el que dos personajes -a veces más- disputan sobre alguna cosa. El segundo vendría a ser el situacional, en el que se presenta a un personaje ante una situación dada y se sacan una serie de conclusiones. Por último, el tercero es el conocido como etiológico, en el que se intenta explicar la causa o el origen de algo. Por otra parte, en cuanto a su relación con otros textos, hemos de señalar que la fábula en la tradición literaria ha aparecido ya como un simple ejemplo (mezclado con otros de carácter mítico o anecdótico o con símiles, proverbios, etc.), ya como un ejemplo "en segundo grado" dentro de otro texto literario (cuentos, apólogos, novelas, ensayos...), esto es, poniéndola en boca de un personaje dentro del mismo, ya en colecciones en que se las coloca unas detrás de otras a modo de retahíla desordenada, o bien empleando un marco que las organiza y las ordena en función de criterios específicos.

Centrándonos por último en los personajes que protagonizan las fábulas, hay que indicar que los mismos, tal y como señala Rodríguez Adrados (2005), actúan como símbolos de los distintos caracteres humanos; la acción que sucede entre ellos es paradigmática de lo que ocurre entre las personas. A esto debemos añadir su carácter atemporal y constante, pues los patrones de comportamiento serían idénticos en tiempos y lugares diferentes. Y ello debido a que la naturaleza de los hechos es la misma: el disfraz o la condición social, la edad, etc., no cambian la manera de actuar de los animales y, por ende, de los hombres. La concepción de la vida humana que subyace a ellas es realista y satírica a pesar de que se añaden con frecuencia rasgos cómicos a los animales. Sin embargo, esto no oculta, sino que aviva más, la dureza de la vida, la cual es concebida como un constante enfrentamiento entre seres humanos, como una lucha encarnizada de los unos por imponer su poder y de los otros por evitar ser sometidos al mismo.

\section{ESOPO Y SU LEGADO MORALISTA}

Como ya ha quedado dicho fue Esopo el autor al que se atribuyó el origen de la fábula ya por los autores del siglo $\mathrm{V}$ a. C., convirtiéndose así en una figura emblemática, cuyo nombre fue siempre citado a la hora de componer nuevos textos. A pesar de esto, 
pocos datos poseemos -y algunos de ellos no muy fiables- respecto a la existencia de su persona; algunos nos lo sitúan en el siglo VI a. C. como natural de Frigia o Tracia. A él se hace referencia en algunos pasajes de obras de autores como Herodoto, Aristófanes, Platón, Aristóteles o Fedro. En los mismos se nos describe al autor como esclavo de un tal Iadmón en la isla de Samos, donde comparte tal condición con Rodopis, amante del hermano de Safo. Asimismo, se menciona su muerte a manos de los habitantes de Delfos, acusado falsamente de un robo sacrílego.

Así pues, siguiendo a García Gual (1976), tenemos que la fábula esópica fue más el nombre que se atribuyó a las recopilaciones de fábulas con las que posteriormente se formaron colecciones, que a una creación propia y exclusiva de dicho autor. La primera de estas recopilaciones de las que tenemos constancia es la que, alrededor del año 300 a. C., escribió el filósofo Demetrio de Falero. En ella se encuentran recogidas y prosificadas fábulas empleadas como modelos de conducta en la literatura anterior y presentadas como piezas en un corpus organizado. Además de la mencionada, nos han llegado otras tres colecciones de la época antigua greco-latina: la de Fedro, la de Babrio y una de Fábulas Anónimas Griegas. En las mismas las fábulas de animales se encuentran mezcladas con cuentos, máximas y anécdotas con función moralista y persiguiendo objetivos de aprendizaje en las escuelas. Algunas colecciones posteriores son las de Dositeo (siglo II), Libanio y Aftonio (siglo IV) y Aviano (finales del siglo IV).

Situándonos ya en la Edad Media, hallamos que en esta época se recogió la tradición esópica adquiriendo la fábula gran popularidad entre el pueblo, y empleándose tanto como elemento moralizador como a modo de sátira. En la España bajomedieval España recibió y a su vez transmitió los fabularios medievales orientales: de esta manera Pedro Alfonso compuso, a principios del siglo XII, una compilación de apólogos orientales, traducidos del árabe al latín que tituló Disciplina clericalis. Por su parte, Alfonso X, en 1251, encargó la traducción del Calila y Dimna y del Sendebar de orígenes probablemente indios. En los siglos siguientes, XIV y XV se desarrollaron fábulas y apólogos en las obras del Arcipreste de Hita y de Don Juan Manuel.

Posteriormente, el siglo XVI fue un período de transición ya que, a pesar de que las fábulas tuvieron su importancia, fueron realmente los siglos XVII y XVIII en los que la fábula alcanzó su máximo esplendor. Tal como indica Janssen (1955), La Fontaine empleó en Francia el antiguo género revestido de nuevos motivos y de él partió la concepción moderna de la fábula como género exclusivamente animalístico. Gracias al francés el género recibió un impulso renovado que se plasmó en Gay en Inglaterra, Lessing en Alemania, Pignotti en Italia o Krylov en Rusia.

\section{LA INMANENCIA DE LA TRADICIÓN ESÓPICA MÁS NEGATIVA EN ALGUNOS FABULISTAS ESPAÑOLES DE LOS SIGLOS XVIII Y XIX}

Tras el recorrido histórico realizado anteriormente por los autores europeos de fábulas que más se han visto influidos por Esopo, nos centraremos ahora en la tradición española. Más concretamente, vamos a analizar las que fueron, sin duda, las cuatro figuras más destacadas en este ámbito en los siglos XVIII y XIX. A saber: Tomás 
de Iriarte y Félix María de Samaniego en el setecientos y Ramón de Campoamor y Juan Eugenio de Hartzenbusch en el ochocientos. De entre sus producciones fabulísticas, aquí vamos a examinar la parte de ellas que ofrece la visión más estereotipada y tendenciosa del imaginario social occidental, la cual han recogido de Esopo y de otros fabulistas a los que éste inspiró y, posteriormente, han reelaborado y versionado según las costumbres del momento.

De acuerdo con esto, vamos a presentar las producciones fabulísticas en torno a dos asuntos de carácter social que se han enfocado a lo largo de la historia de Occidente desde un punto de vista exclusivista y sesgado, y casi siempre con un marcado carácter impositivo. El primero de ellos tiene que ver con la tradicional regulación jerárquica de las sociedades dependiendo de las etnias a las que éstas den cabida. Así, la sociedad occidental ha visto en los extranjeros con un color negro de piel -fundamentalmente personas orientales o latinoamericanas- a seres inferiores incapaces de razonar $y$, a veces incluso, asimilables a animales como el mono. El segundo se relaciona con la manera en que, dentro de la sociedad occidental, se han establecido una serie de prototipos y juicios de valor apriorísticos acerca de las características que deben tener los hombres y las mujeres para ser considerados a todos los efectos como tales. Toda persona que no cumpliera con estos requisitos asociados a su género podía y, aún en ocasiones, puede ser ninguneada o defenestrada en determinados círculos sociales.

Con el fin de estudiar la inmanencia en los autores españoles de los siglos XVIII y XIX de fábulas de esta temática que ya aparecía en Esopo, vamos a presentar a continuación ejemplos de los dos tipos partiendo de los textos del griego. Veremos así como dichas fábulas han ido ramificándose y asentándose literariamente y, por ende, en el pensamiento colectivo de la sociedad europea en general y la española en particular, si no en su totalidad por ser muy grande la hostilidad que las originales presentan, sí en ciertos adjetivos y atributos con que se califica y cualifica a determinados personajes que cumplen con la condición que es objeto de ataque y/o burla.

\section{1 "El negro" y "El carro de Hermes y los árabes"}

Son dos las fábulas de Esopo en las que se muestra de manera más contundente el sesgo racista al que hemos hecho referencia anteriormente. Se trata de las tituladas "El negro" y "El carro de Hermes y los árabes". En la primera de ellas se nos presenta una situación en que un hombre compra un criado negro para, a continuación, intentar quitarle ese color de piel que él cree que es debido a su falta de higiene y, en la segunda, se caracteriza a los árabes como a la etnia más mentirosa, malvada y falsa de las que existen en el mundo. Presentamos los ejemplos:

\section{"El negro"}

“Un hombre compró un negro creyendo que tenía tal color por descuido de su anterior dueño. Y, cuando lo llevó a su casa, le aplicó todo tipo de jabones e intentó limpiarlo con baños de toda clase. Y no pudo cambiar su color, pero le hizo enfermar. La fábula muestra que las naturalezas se mantienen como fueron al principio". (Esopo, 2011:26) 
"El carro de Hermes y los árabes"

\begin{abstract}
“En cierta ocasión, Hermes conducía por toda la tierra un carro lleno de mentiras, malicia y engaño, e iba distribuyendo un poco de carga en cada territorio. Se dice que el carro se rompió de repente cuando llegó al territorio de los árabes. Éstos arrebataron la carga que iba en él como si fuera muy valiosa y no permitieron que siguiera adelante hacia otros hombres. Los árabes son mentirosos y mendaces por encima de toda raza. Pues en su lengua no hay verdad". (Esopo, 2011:71)
\end{abstract}

Siguiendo este tono de menosprecio y descalificación hacia los miembros de las culturas con usos, costumbres y religiones diferentes a las europeas y con atributos étnicos distintos, los fabulistas españoles de los siglos XVIII y XIX realizaron una serie de composiciones en las que continuaron con este trazado tendente a mancillar la dignidad y el valor humano de los habitantes de estos pueblos. De esta manera, comenzando por el siglo XVIII, nos encontramos con que seguramente los dos fabulistas españoles más reconocidos, como son Tomás de Iriarte y Félix María de Samaniego, escribieron algunas en las que se sigue esta concepción cultural jerarquizada. Así en el primero de ellos tenemos fábulas como "Los huevos" y "La mona" en las que, ya se muestra el desdén por los sitios lejanos de oriente como las Islas Filipinas a los que ni siquiera han llegado los huevos, ya se sitúa como lugar de origen de las monas la ciudad marroquí de Tetuán con un evidente afán despreciativo. En el segundo, tenemos textos como “El leopardo y las monas", "La mona corrida" y “La moda” en los que se sigue haciendo hincapié en que Marruecos es el país de los monos por excelencia, cuyos pobladores siguen modas y costumbres anticuadas y propias de salvajes.

Del mismo modo, también en los fabulistas del siglo XIX español podemos hallar renovada esta concepción discriminatoria en autores como Ramón de Campoamor y Juan Eugenio de Hartzenbusch. Del creador asturiano sobresale en este sentido la titulada "El pastor y el navío", en la que se pone en evidencia el carácter eminentemente colonialista de las potencias europeas respecto a las regiones latinoamericanas y orientales. Por su parte, en el autor madrileño son bastantes numerosas las que se centran en estos asuntos pudiéndose destacar las intituladas "La tierra de los cojos", "El loro", "El reloj de sol" y "Los caribes", en las que es recurrente el tema de los defectos físicos e intelectuales que presentan los oriundos de tierras ajenas cultural y simbólicamente al espacio de dominio occidental.

\title{
4.2 "Zeus y la vergüenza"
}

Constituye la fábula denominada "Zeus y la vergüenza" el testimonio explícito más elocuente del rechazo hacia una concepción identitaria abierta del hombre y de la mujer, la cual les permita ejercer cualesquiera actos con total libertad. Se ofrece en ella una visión unívoca de cada género con el fin de que cada uno de ellos sepa cuáles son los patrones físicos y psicológicos que están acordes con él y se adecúen a lo que se espera si siguen "naturalmente" sus inclinaciones íntimas. Cualquier otra manera de entender el concepto de hombre y de mujer y, por supuesto, tener inclinaciones homosexuales resulta una corrupción de la naturaleza, una aberración y una falta de vergüenza. Vemos el texto esópico: 
"Cuando Zeus modeló a los hombres, insufló en ellos los demás sentimientos, pero olvidó
la vergüenza. Y al no saber por dónde introducirla, ordenó que penetrara por el ano. Ésta,
indignada, al principio se opuso. Pero, cuando Zeus le insistió con rotundidad, dijo: <<Entro con
la condición de que no se introduzca Eros: si entra él, yo me saldré al instante>>. De aquí viene
el que todos los invertidos son desvergonzados. La fábula muestra que los que son dominados
por Eros son desvergonzados". (Esopo, 2011:73)

De manera análoga a lo ocurrido con el motivo isotópico anterior, la propagación de fábulas de índole homofóbica llegó hasta los siglos XVIII y XIX en los que podemos encontrar composiciones dirigidas a moralizar sobre las inclinaciones sexuales de hombres y mujeres, las cuales no deben sólo ser acatadas internamente sino ser demostradas externamente mediante la asunción de ropas, maneras y costumbres adecuadas. A este respecto, en el siglo XVIII descubrimos en Samaniego la fábula titulada "El chivo afeitado" que ataca al varón que se perfuma, se cuida y se afeita tildándolo de vanidoso y de poco hombre. También encontramos en el XIX dos fábulas de Hartzenbusch que hablan sobre la necesidad de que los hombres y las mujeres no se desvíen de los comportamientos que la naturaleza les impone por pertenecer a uno u otro sexo. Las mismas se titulan "Los premios de la emperatriz" y "Las furias".

\section{5. ¿PODEMOS UTILIZAR ALGUNAS DE LAS FÁBULAS ESÓPICAS DE LA TRADICIÓN ESPAÑOLA COMO RECURSO EDUCATIVO EN LAS AULAS DE EDUCACIÓN PRIMARIA PARA EDUCAR EN VALORES? REFLEXIONES Y PROPUESTA DIDÁCTICA}

A la vista del pensamiento tendencioso que se trasluce en las fábulas de Esopo seleccionadas y en sus posteriores versiones españolas en los siglos XVIII y XIX, puede parecer, en cierta medida, contraproducente llevar a las aulas de Educación Primaria una serie de textos que defienden en sus líneas ideas como el segregacionismo intercultural o una concepción rígida y castrante de la persona en función de su género. Sin embargo, desde nuestra perspectiva docente, y siguiendo a Kohler (2007), consideramos que para nuestros estudiantes puede, sin duda, resultar más rica y significativa una educación en valores basada en la construcción, por su parte, de un pensamiento crítico y sensible con los diferentes a ellos, que cualquier otro instrumento que defienda, sin meditación de ningún tipo, un decálogo de conductas a adoptar que serán conocidas y hasta aprobadas en teoría pero, en muchos casos, no asumidas internamente y, por tanto, no observadas en la práctica.

Teniendo claro nuestro objetivo, vamos a intentar llevarlo a la práctica ofreciendo una propuesta didáctica basada en la presentación de actividades que persiguen, fundamentalmente, la identificación de los contravalores de algunas fábulas seleccionadas con el fin de fomentar la comprensión, el respeto y el entendimiento mutuo entre las personas, por diferentes que sean los puntos de anclaje que sustenten su mundo (Hall, 1989). Presentando ya la elección en sí, se compone la misma de dos fábulas de dos autores españoles de épocas diferentes, Samaniego del siglo XVIII y Hartzenbusch del XIX. Del primero hemos escogido las fábulas “La moda” y “El chivo afeitado" y del segundo "La tierra de los cojos" y "Los premios de la emperatriz". A 
continuación presentaremos los textos transcritos y, más abajo, las preguntas sobre las que deberán interactuar los alumnos entre sí y con el profesor, el cual actuará como guía del aprendizaje de las competencias sociocultural e intercultural, a imagen de una antigua mayéutica sofística aquí renovada y llevada a las aulas actuales.

- Fábulas de Félix María de Samaniego

"La moda"

“Después de haber corrido cierto danzante Mono por cantones y plazas, de ciudad en ciudad, el mundo todo, logró, dice la historia aunque no cuenta el cómo, volverse libremente a los campos del África orgulloso. Los monos al viajero reciben con más gozo que a Pedro el zar los rusos, que los griegos a Ulises generoso. De leyes, de costumbres, ni él hablo ni algún otro le preguntó palabra; pero de trajes y de modas, todos. En cierta jerigonza, con extranjero tono les hizo un gran detalle de lo más remarcable a los curiosos. -Empecemos, decían, aunque sea por poco. Hiciéronse zapatos con cáscaras de nueces, por lo pronto. Toda la raza mona andaba con sus choclos, y el no traerlos era faltar a la decencia y al decoro. Un leopardo hambriento trepa para los monos: ellos huir intentan a salvarse en los árboles del soto. Las chinelas lo estorban, y de muy fácil modo aquí y allí mataba, haciendo a su placer dos mil destrozos. En Tetuán, desde entonces manda el senado docto que cualquier uso o moda, de países cercanos o remotos, antes que llegue el caso de adoptarse en el propio, haya de examinarse en junta de políticos, a fondo. Con tan justo decreto y el suceso horroroso, ¿dejaron tales modas? Primero dejarían de ser monos". (Samaniego, 2004:335-337)

Actividades propuestas a modo de debate grupal tras una lectura atenta del texto:

- ¿Qué ciudades del mundo pudo visitar el mono danzante protagonista de la fábula?

- ¿En qué país se encuentra la ciudad de Tetuán? ¿Qué sabéis sobre el mismo y sobre sus costumbres? ¿En qué se diferencian de las vuestras?

- ¿Es dicho país un lugar en el que haya realmente muchos monos? ¿Creéis que el fabulista se puede referir malintencionadamente a los habitantes del mismo?

- Si es así... ¿Veis adecuada la moraleja “ ¿dejaron tales modas? Primero dejarían de ser monos" con que termina el texto?

- ¿Os gustaría que a vuestro país y a vosotros se os identificase como a monos carentes de uso de razón?

\section{"El chivo afeitado"}

“Un chivo, como muchos en el mundo, vano extremadamente, se miraba al espejo de una fuente. $<<_{i}$ Qué lástima, decía, que esté mi juventud y lozanía por siempre disfrazada debajo de esta barba tan poblada!>>. El chivo fue, guiado de su tono, a la tienda de un mono, barberillo afamado, que afeitó al señorito de contado. Sale barbilampiño a la campaña. Al ver una figura extraña, no hubo perro ni gato que no le hiciese burla al mentecato. Los chivos le desprecian de manera, que no hay más que decir. ¡Quién lo creyera!, un respetable macho dicen que se rió como un muchacho". (Samaniego, 2004:302-303) 
Actividades propuestas a modo de debate grupal tras una lectura atenta del texto:

- ¿Qué animal es el chivo? ¿Sabríais dibujarlo?

- ¿Qué os parece que el chivo quiera cuidar su aspecto personal? ¿Debe dejar de hacerlo por ser varón?

- ¿Entendéis las burlas y desprecios hacia él por quitarse la barba? ¿A qué las achacaríais? ¿os gustaría que os las hicieran a vosotros?

- ¿Tiene el hombre un prototipo determinado acerca de cómo ser y cómo vestir en la sociedad actual? ¿Debería tenerlo?

- ¿Entendéis que se pueda marginar a alguien por ser distinto del resto?

- Fábulas de Juan Eugenio de Hartzenbusch

$$
\text { "La tierra de los cojos" }
$$

“No lejos del Estrecho, que hoy es de Gibraltar apellidado, hubo antes un país, ya sepultado por la furia del mar. Allí no había ni un hombre que al andar fuese derecho: ley natural, que de sorpresa embarga, por única en el mundo todavía, nacer a los indígenas hacía con una pierna corta y la otra larga. Salta, pues, a los ojos, que a tal disposición de piernas, era consiguiente y precisa la cojera; pues aunque hay muchos cojos por varias causas, que decir no importa, cojo es el que se ve, por su desdicha, con una pierna larga y la otra corta, o, términos usando generales, el que tiene las piernas desiguales. Aparte de la gracia susodicha, cual si tuvieran en la lengua nudos, mujeres y varones, hablaban además a trompicones: cojos eran, en fin, y tartamudos. Arribó a este país un europeo, y al notar circunstancia tan chocante, dijo muy arrogante: -Rey voy a ser aquí, pues no cojeo. El hombre se llevó terrible chasco. No bien de una ciudad las calles pisa, cuando viéndole andar los moradores, quién de lástima exclama, quién de risa: fruncen el gesto, y aparentan asco señoritas, señoras y señores: haciendo muecas y soltando pullas, sigue la multitud al forastero, que anda como los pavos y las grullas; y hasta un despilfarrado zapatero, asiéndole del brazo, en tomarle medida se empeñaba, para hacerle una bota, que supliera con lo alto del tacón el gran pedazo que, según él juzgaba, en una pierna al otro le faltaba, ya no pudo callar. -Pueblo sin juicio, grita con voz robusta y altanera, ir derecho no es vicio; lo vicioso y lo feo es el vaivén, el torpe bamboleo que sin cesar vais dando por no poder andar: yo soy el que ando; y atónitos de ver mi gallardía, cada cual imitarme debería, si esto le fuese dable a una turba de cojos miserable. Todas estas injurias imprudentes no las oyeron bien aquellas gentes; pues como al son de la primera frase del colérico huésped, observaron que no era tartamudo, no esperaron a que él sus invectivas acabase, para aturdirle a voces y silbidos. Cosa fue de taparse los oídos. -¡Qué-qué-qué-qué, decían, lengua-guaje! De-de lo que habla el mu-mu-muy salvaje, la-la mi-mi-mitad se-se co-come, que un ma-maestro se-se le-le lleve, y a fu-fu-fuerza de-de zu-zurridos, que-que la-la costu-tu-tumbre tome de-de hablar y an-andar co-como debe. Si en escapar de allí se tarda un poco, me le enjaulan por loco. Tal suele acontecer al desdichado, que a combatir se atreve un error por el tiempo consagrado". (Hartzenbusch, 1999:86-88)

Actividades propuestas a modo de debate grupal tras una lectura atenta del texto:

- ¿Creéis que hay alguna explicación razonable para que la "Tierra de los Cojos" se sitúe más allá del "Estrecho de Gibraltar"? ¿Qué países podemos encontrar en esa parte del mundo? ¿Elige el autor la zona de forma inocente?

- ¿Hay algún país en que los hombres nazcan todos ellos con defectos físicos congénitos por ser de una determinada zona del mundo? 
- ¿Cómo interpretaríais la aseveración que hace el autor acerca de que en ese país "ir derecho es vicio"? ¿Tiene algo que ver con la dicotomía OrienteOccidente?

- ¿Creéis que el carácter salvaje de los hombres de este país es real o es la manera de presentárnoslos del hombre europeo lo que hace que los veamos así?

- ¿Creéis que somos los europeos un pueblo que acoge de forma agradable a los habitantes de otras culturas? ¿Por qué?

"Los premios de la emperatriz"

\begin{abstract}
“La Emperatriz Sofía cuatro veces al año repartía en pública sesión dos medallones, cada cual de valor de cien doblones, premio del colegial y colegiala que eran en los exámenes juzgados en grado superior aventajados. Vestiditos de gala, y de curiosa multitud cercados, entraban juntos en la rica sala, donde, al son de trompetas y atabales, a veces con la joya recibían otros diversos dones de las pródigas manos imperiales; al paso que en algunas ocasiones corridos niño y niña se veían al recibir, delante de aquel numerosísimo concurso, dádiva tan chocante, que la plebe y la corte, sin recurso, burlábanse con dura pertinacia de los dos angelitos: verbi gracia, Benito y Valentina, chicos de doce abriles, él docto en la gramática latina, y hábil ella en labores femeniles, fueron los dos electos por la junta de escuelas competente como pareja igual, sobresaliente, como alumnos perfectos de latín y costura. Lindamente. Pero es el caso que en palacio había un pajarito azul, que los defectos de los niños de escuela descubría; y el pájaro maldito contó a la Emperatriz...(iQué picardía! yo, vamos, el pescuezo le torciera), contó de Valentina y de Benito la corta friolera de que él era un llorón y ella una fiera. Ya llegó el día de función prescrito. La señorita, pues, y el señorito prepáranse de prisa y van despacio (porque mejor los miren) a palacio. Su Majestad al cuello les pone, al son del atabal sonoro, los codiciados medallones de oro; y después (aquí es ello) dice a Benito así: -Cierta avecilla que os atisba las faltas y las pilla, te acusa de marica y apocado; por lo cual, que te compren he mandado ese cumplido chal y esa mantilla: póntelos de contado. Y usted, dijo a la niña, que es persona del sexo débil y de clase fina; pero que audaz y díscola y gritona, en vez de Valentina, merece que se la llame Valentona, sepa que por sus rústicas hombradas, le va a plantar aquí mi camarera un par de charreteras encarnadas y una gorra de pelo granadera. Pues o renuncian a su ser y nombre, o han de tener por cualidad primera dulzura la mujer, valor el hombre". (Hartzenbusch, 1999:27-28)
\end{abstract}

Actividades propuestas a modo de debate grupal tras una lectura atenta del texto:

- A vuestro entender...¿Tiene que ser la mujer llorona y el hombre valiente? ¿Son estos papeles estables o dependen del momento y de la situación en que la persona se encuentre?

- ¿Existe algún sexo que sea “débil” tal y como se lee en la fábula? ¿Cuál? ¿Por qué?

- ¿Tienen los hombres y las mujeres que trabajar en un oficio adecuado a su género? ¿Qué os parece?

- ¿Es ético que se insulte a alguien por su orientación sexual? ¿Lo habéis hecho? ¿Lo habéis sufrido?

- ¿Estáis de acuerdo con la moraleja final "O renuncian a su ser y nombre, o han de tener por cualidad primera dulzura la mujer, valor el hombre" ? ¿Por qué? 


\section{CONCLUSIONES}

Tras haber realizado este trabajo de investigación centrado en la reflexión teórica sobre la adecuación ética o no de determinadas cuestiones que se encuentran en determinadas fábulas esópicas, y en la aportación de una propuesta práctica para las aulas de Educación Primaria que trata de inducir a la reflexión crítica por parte del alumnado, hemos llegado a una serie de conclusiones sobre las cuales podrán estar de acuerdo o no otros investigadores. Son las siguientes: 1) Creemos sinceramente que hay un desconocimiento generalizado en Occidente sobre la fabulística oriental, pues no hay apenas estudios realizados sobre el tema y, además, frecuentemente se ignora que gran parte de las fábulas griegas se apoyan en temas y asuntos que ya se encontraban en las composiciones indias y mesopotámicas, 2) Esopo como autor debe quedar definitivamente reducido a una figura mítica, pues la mayoría de las fábulas que a él se atribuyen son de carácter anónimo y fueron transmitidas oralmente de generación en generación, 3) La tradición fabulística europea de los siglos XVIIXIX, y también la española, se hizo eco de determinados estereotipos racistas, con el objetivo de servir a intereses económicos, sociales e ideológicos, fundamentalmente en la cuestión colonialista, 4) No todas las fábulas presentan un modelo de conducta ejemplar hacia determinados grupos sociales desde los parámetros vigentes en el siglo XXI y 5) Consideramos que una buena manera de llevar al aula de Educación Primaria las fábulas más controvertidas de la tradición esópica, podría ser a través de la presentación de las mismas partiendo de contraejemplos que sirvan a los estudiantes como motivo de debate y de reflexión.

\section{BIBLIOGRAFÍA}

Campoamor, R. de (1941): Fábulas completas, Buenos Aires. Ed. Sopena.

Esopo (2011): Fábulas, Madrid, Ed. Alianza.

García Gual, C. (1976): “Historia y ética de la fábula esópica”. En Actas del V Congreso Español de Estudios Clásicos, Madrid.

Hall, E. T. (1989): Understanding cultural differences, Maine, Ed. Intercultural Press.

Hartzenbusch, J. E. de (1999): Fábulas, Madrid. Ediciones Internacionales Universitarias. Iriarte, T. de (1992): Fábulas literarias, Madrid, Ed. Cátedra Letras Hispánicas.

Janssen, J. (1955): La fable et les fabulistes, Bruselas, Ed. Collection Lebègue et nationale. Kohler, F. (2007): Stéréotypes culturels et constructions identitaires, Tours, Ed. Presses Universitaires François Rabelais.

López Casildo, G. (2011): “Introducción”. En Esopo, Fábulas, Madrid, Ed. Alianza, pp. 7-17.

Rodríguez Adrados, F. (2005): De Esopo al Lazarillo, Huelva, Ed. Servicio de Publicaciones de la Universidad de Huelva.

Samaniego, F. M. de (2004): Fábulas, Barcelona, Ed. Debolsillo 



\title{
A INSCRIÇÃO DA ‘VIDA DE ESOPO' NAS PRIMEIRAS COLECÇÕES DE FÁBULAS EM PORTUGUÊS: LIVRO DE EXOPO (SÉC. XIV) E VIDA E FÁBULAS DO INSIGNE FABULADOR GREGO ESOPO TRADUZIDAS POR MANUEL MENDES DA VIDIGUEIRA (1603/1643)
}

\author{
ANA PAIVA MORAIS \\ Universidade Nova de Lisboa, FCSH-IELT ${ }^{1}$
}

\begin{abstract}
Resumen
Con frecuencia, la Vida de Esopo se encuentra en las colecciones de fábulas posteriores a la impresión de Steinhöwel de 1476 - Esopo de Ulm - como prólogo. Su situación de escalón previo sirve excelentemente para inscribir la marca del autor y legitimar, a finales de la Edad Media, las colecciones de fábulas. La segunda de las dos primeras colecciones en portugués actualmente conocidas - Livro de Exopo (século XIV) e Vida e fábulas do insigne fabulador grego Esopo traduzidas por Manuel Mendes da Vidigueira (1603/1643) - sigue la tradición que empezó en el Esopo de Ulm. La primera, que es anterior a la edición de Steinhöwel, no incluye la Vida de Esopo. Sin embargo, presenta en su prólogo algunos datos biográficos del poeta griego, lo que resulta ser un trazo singular en el conjunto de las colecciones coevas y de las que la procedieron. En este artículo, examinaré las marcas de la vida de Esopo inscritas en el prólogo del Livro de Exopo y en la Vida de Esopo de la colección de 1603/1643 y analizaré los modos de construcción textual del autor de fábulas.
\end{abstract}

Palabras clave: fábulas - vida de Esopo - biografía

\begin{abstract}
:
A Life of Aesop has often been included in fable collections printed after Steinhöwel's 1476 edition, also known as the Ulm Aesop. It's location before the fables - as a prologue, where the author is usually introduced -, has been used efficiently in late medieval fable collections to confirm the fable as a genre. Of the two first known books of fables in portuguese - the Livro de Exopo (14th century) and the Vida e fábulas do insigne fabulador grego Esopo translated by Manuel Mendes da Vidigueira (1603/1643) - only the second one opens with a Life of Aesop, since it is the first to be published in portuguese after the Ulm's Aesop was printed. As for the Livro de Exopo, it also includes several topics from Aesop's biography, something that rarely happens in contemporary or earlier collections. This article examines the inclusion of topics from Aesop's biograhy both in the Livro de Exopo's prologue and in the Vida de Esopo (Life of Aesop) from
\end{abstract}

\footnotetext{
${ }^{1}$ Este artigo é apresentado no âmbito do projecto "A Fábula na Literatura Portuguesa: Catálogo e História Crítica", PTDC/CLE-LLI/100274/2008, financiado pela FCT - Fundação para a Ciência e a Tecnologia, e tem por instituição de acolhimento a Faculdade de Ciências Sociais e Humanas da Universidade Nova de Lisboa e por unidade de investigação de acolhimento o IELT - Instituto de Estudos de Literatura Tradicional.
} 
Mendes da Vidigueira's collection, and it aims to show how the author becomes a fictional character in these two collections of fables.

Key words: fables - life of Aesop - biography

\section{MARCAS DA BIOGRAFIA DE ESOPO NO LIVRO DE EXOPO}

As duas primeiras colecções completas de fábulas em língua portuguesa actualmente conhecidas apareceram numa época relativamente tardia, se compararmos o desenvolvimento das colecções de fábulas em português com o dos fabulários em outras literaturas europeias.

A primeira delas, denominada, na sua última edição, Livro de Exopo, é datada do século XIV na sua redacção primitiva, compõe-se de 63 fábulas em prosa e dos respectivos epimítios moralizados, e é encabeçada por um prólogo. Desta colecção em versão portuguesa conhece-se um único manuscrito, do século XV, que está conservado na Biblioteca Nacional de Áustria com a cota $3270^{*}$, onde foi descoberto acidentalmente por José Leite de Vasconcelos em 1900 e que conheceu, até à data, três edições: J. Leite de Vasconcelos, na Revista Lusitana (Vasconcelos 1906); Juvino Alves Maia Junior, que dela estabeleceu uma edicão crítica em dissertação de mestrado apresentada à Universidade de São Paulo em 1993 (Maia Junior, 1993); Adelino Almeida Calado, que editou o Livro de Exopo em 1994 (Calado, 1994).

A genealogia do fabulário português, traçada com base em análises do próprio Vasconcelos (1906) e de Keidel (1908), e actualizada por Calado (1994), demonstra que esta colecção entronca na paráfrase realizada no século XII, em Inglaterra, por autor anónimo que se acreditou ser Walter ou Gualterus Anglicus, hoje habitualmente denominada Anonymus Neveleti, e segue a versão ampliada, que contém 63 fábulas.

O cotejo das fábulas do Livro de Exopo e do Anonymus confirma que a colecção portuguesa seguiu a tradição deste último, apesar de não se crer que tenha sido por via directa, mas antes remotamente, baseada naquela colecção, por meio de um modelo intermédio, coligido em prosa latina, que, segundo Keidel, teria sido uma cópia italiana (Vasconcelos, 1906: 99 e 102 e Keidel, 1908: 92-94). Apesar destes contributos, são ainda grandes as dificuldades em determinar com alguma precisão a fonte próxima do tradutor do Livro de Exopo, assim como subsistem problemas consideráveis na percepção das alterações que foram introduzidas no texto português, ainda que seja possível identificar o conjunto de provérbios portugueses introduzidos no texto como uma marca provável de intervenção de cunho pessoal (Calado, 1994: 9), tal como notaram Vasconcelos e Keidel, corroborados por Calado.

A estes problemas levantados pela colecção medieval em língua portuguesa acresce um outro a que aqui daremos maior atenção: o da autoria do fabulário, ou mais precisamente, o da representação do autor de fábulas no Livro de Exopo. Na sua recensão do Livro de Esopo editado por Vasconcelos e publicado em 1906, Keidel dedicou uma larga parte do seu texto ao exame das fontes deste fabulário, dando particular 
desenvolvimento àquela que é referida no prólogo (Keidel, 1908: 90)². Com efeito, a única fonte directamente citada pelo autor do Livro de Exopo é o Livro da vida e dos custumes dos philosofos, do qual não se conhece cópia medieval em língua portuguesa, mas de que existem três testemunhos em espanhol com o título Vida y costumbres de los viejos filosofos ${ }^{3}$, derivadas da versão latina da autoria do inglês William Burley, Liber de vita et moribus philosoforum, que teve larguíssima difusão ao longo dos séculos XIV e XV (Knust, 1886). William, por sua vez, terá usado como fonte da vida de Esopo ou directamente a colecção de fábulas de Vincent de Beauvais, inserida no Speculum Historiale (Vincent de Beauvais, 1624), ou uma fonte comum a esta obra (Knust, 1886), o que permite concluir, como o fez Keidel, que o texto do Livro de Exopo no que respeita à vida de Esopo está, de certa forma, ligado ao do autor francês por intermédio da obra citada no prólogo, ainda que as conexões entre estes textos careçam de esclarecimentos mais precisos ${ }^{4}$.

Em todo o caso, a invocação do nome de Esopo na abertura das colecções parece ter tido, desde muito cedo, o efeito de contrariar a dispersão de um corpus que de carácter marcadamente heterogéneo, se tivermos em consideração a constituição das primeiras colecções (Biscéré, 2009: 9-17)5 ${ }^{5}$ dispersão que se manteve como uma força activa na vida deste género. Por outro lado, a referência a Esopo nos prólogos também permitiu contrariar a oscilação ou a indefinição das fábulas entre narrativa e moral e diminuir a própria falta de clareza dos termos 'mythos' e 'logos' nas suas várias aplicações em tratados técnicos sobre a fábula na Antiguidade devido à sua polissemia (Dijk, 1993). Compreende-se que as elaborações históricas à volta do nome do protofabulador possam ter contribuído, em primeiro lugar, para conferir algum grau de estabilidade, e de credibilidade, a um conjunto de narrativas de valor e função imprecisos.

Assim, como recorda van Dijk, desde a Antiguidade Clássica, a associação do nome de Esopo às fábulas processa-se de quatro maneiras possíveis: 1 - a fábula é apresentada como sendo contadas por Esopo; 2 - Esopo é a personagem principal da

\footnotetext{
${ }^{2}$ São identificados por Keidel quatro grupos de fontes do Livro de Exopo: $1^{\circ}$ - as que se referem à vida de Esopo que constitui a primeira parte do prólogo; $2^{\circ}$ - relativas à caracterização das fábulas na segunda parte do prólogo; $3^{\circ}$ - respeitantes às fábulas propriamente ditas; $4^{\circ}$ - fontes referentes aos epimítios moralizados, com as suas explorações alegóricas, as referências e as citações de outras obras.

${ }^{3}$ Knust editou uma versão da Vida y costumbres... a partir do manuscrito escurialense, o único conhecido na época. Recentemente, Francisco Crosas (Crosas 2002) editou um outro testemunho deste texto.

${ }^{4}$ Note-se a persistência, nas traduções francesas do Speculum historiale, dos motivos inseridos no prólogo do Livro de Exopo: Hugues Vaganay (1913): 67-82.

${ }^{5}$ Ao analisar a constituição do corpus das fábulas na tradição grega, A. Biscéré introduz uma importante questionação acerca da relação entre o autor e o género: “Telle est donc la nature du corpus des 'Fables d'Ésope': un ensemble hétérogène et relativamente tardif, une trame fabuleuse à plusieurs mains, dont la plus ancienne collection est, au mieux, contemporaine de Phèdre, au pire, bien postérieure à Babrius. Pour nous, modernistes, lecteurs de La Fontaine, le plus important est maintenant de savoir comment les éditeurs scientifiques, et à leur suite les éditeurs et traducteurs qui ont mis à la portée de tous le texte des fables grecques, se sont arrangés de cette situation. Que lisons-nous, nous lecteurs français, lorsque nous lisons ce qui nous est présenté comme des 'Fables' d'Ésope dans l'édition bilingue de Chambry ou dans celle plus récente de Daniel Loayza par exemple?" (Biscéré: 2009: 17b).
} 
fábula; 3 - diz-se da fábula que é 'de Esopo'; 4 - ou que é 'esópica' (van Dijk 173-74). Também na Idade Média, a permanência do nome de Esopo no título em detrimento do nome de outras instâncias autorais mais recentes mostra quão importante é o nome do autor para a percepção das fábulas enquanto tal, e é possível afirmar, como Brun, que no caso das fábulas o que distingue a obra é o seu autor (Brun, 2004: 27)6.

No Livro de Exopo, é a situação descrita por van Dijk em 1 que predomina, e ela verifica-se no contexto do prólogo e não de uma ou várias fábulas em particular, aplicando-se, assim, a toda a colecção na sua generalidade. O nome de Esopo é citado por três vezes no prólogo do fabulário português, em estreita conexão com a tradição biográfica desde cedo estabelecida, e, mais em particular, com a configuração biográfica do autor no Speculum Historiale, onde ele figura em igual número de referências onomásticas, para além de se verificar a coexistência, nos dois textos, de vários elementos da vida de Esopo. Note-se que as referências ao nome superam em quantidade as da própria fonte referida no prólogo, o que parece indicar uma particular insistência do texto português na biografia de Esopo, que é tanto mais evidente quanto ela é sublinhada pela repetida inscrição histórica do autor: "Conta. sse que no tempo dell.rrey Çiro, rrey de Persia, este autor vivia", (Livro de Exopo: 38, linhas 1-2) e mais abaixo, "Aqueste Exopo, no primeyro anno do predicto rrey Çiro, sse conta que fosse morto de maa morte per emveja" (Livro de Exopo: 38, linhas 9-11). A vida de Esopo encontra-se, pois, toda ela circunscrita historicamente pela figura do rei Çiro, o que contribui para aprofundar a vertente biográfica da figura tutelar das fábulas e para situar as próprias fábulas dentro de uma moldura histórica, além do enquadramento narrativo que a biografia de Esopo também lhes fornece. No entanto, esta relação histórica nada retira à componente lendária que mantém a vida de Esopo no fabulário português, mas antes é uma modalidade da atribuição da autoria que reforça a unidade das fábulas e, assim, sublinha a lógica da sua reunião no livro (West, 1984: 105-135)7. Por um lado, a insistência na vida do autor de fábulas, e, por outro lado, a brevidade desta e a sua inclusão num prefácio que se apresenta compósito e como grande complexidade - onde à biografia se junta a descrição da estrutura da colecção e a explicitação do sentido alegórico das fábulas -, revelam a flexibilidade do enquadramento biográfico, de tal modo que este assegura a unidade na colecção, mas fá-lo de modo suficientemente vago e flexível para permitir a incorporação de alterações e adequações particulares, não só no prólogo como também, e sobretudo, nas fábulas da colecção.

Assim, a autoria de Esopo tem uma função específica, mas ela é mais uma consequência da própria natureza imprecisa e iterativa da fábula do que um factor que possa determinar a configuração das fábulas. A atribuição da autoria insere-se na economia do género da fábula, tal como a matéria trabalhada - "Este Exopo, em

\footnotetext{
${ }^{6}$ Consulte-se mais demoradamente o referido artigo de L. Brun (2004: 23-30) para uma apreciação extensiva da importância da voz do fabulador medieval nas colecções de fábulas, nomeadamente na construção dos títulos e através das menções ao autor nos prólogos.

${ }^{7}$ West sublinha a importância da atribuição biográfica na passagem da circulação dispersa das fábulas à constituição das colecções de fábulas.
} 
aqueste sseu livro, poem muytas estorias ffremosas d.animalias, de homẽes e de aves e de outras cousas, segumdo em elle veredes" (Calado, 1994: 38, linhas 12-14) - ou a configuração alegórica do sentido quando se usa o recurso às figuras e fórmulas tradicionais da interpretação integumental nas colecções de fábulas:

E assemelha este sseu livro a hũu orto no quall estam flores e fruytos. Pellas frores sse emtemdem as estorias e pello fruyto sse emtemde a semtença da estoria. E comvida os homẽes e amoesta.os que venham a colher das frores e do fruyto. Ainda compara este sseu livro aa noz, que ha dura casca, e aos pinhoões, que demto teem ascomdido o meolo, que he ssaborido. Assy este livro tem em ssy escondido muytas notavees semtenças. (Calado, 1994: 38, linhas 17-26)

Neste sentido, é lícito afirmar, como fez Jean-Marie Schaeffer, que a autoria biográfica surgiu graças a um dispositivo de projecção ficcional da origem da fábula. Esta projecção da origem é uma das características constituintes deste género. Por um lado, ela opera retroactivamente ao instituir um pai do género, e, por outro lado, prospectivamente pela dimensão transtextual de que se reveste esta paternidade quando se aplica aquela autoria a todas as fábulas em geral, sejam elas de existência dispersa ou coligidas em fabulário (Schaeffer, 1985: 345-364). A fábula esópica exerceu, desde a Antiquidade, uma forte pressão genológica sobre outras formas da fábula graças à qual a figura do Esopo inventor do género pôde suplantar, no ocidente, outros potenciais responsáveis, tais como o sábio Pilpay e acabar por assimilar tradições variadas das fábulas à dinâmica da origem esópica.

No Livro de Exopo, é curioso notar que a forte marca da autoria existente no prólogo não se repercute da mesma forma nas fábulas, onde o contexto de enunciação tende a eliminar as marcas de uma autoridade personalizada. As fórmulas de introdução das narrativas e dos epimítios moralizados em cada uma das fábulas são significativamente estereotipadas. Até à fábula 17, “O cãozinho e o asno”, a primeira parte das fábulas é introduzida pela expressão "Comta.sse que...” e a moral iniciase por "Em aquesta hestoria o doutor diz que...". A partir daqui, estas expressões são substituídas, respectivamente, por "Pom este doutor (ou poeta) em exemplo e diz que..." e "Per este emxemplo este doutor nos amostra que...". À medida que a colecção vai avançando, a referência ao 'poeta' como auctoritas tende a substituir a de 'doutor', podendo, por vezes, fundir-se em 'doutor poeta's. Seja qual for a expressão usada, a tónica é posta na impessoalidade, sendo a instância de enunciação remetida para uma figura de autoridade não nomeada, mas que não se confunde nem com o inventor do género nem com o redactor. É de salientar, também, a marca acentuada na vertente didáctica das fábulas pelo predomínio do termo 'emxemplo' ou, menos frequentemente, 'ensinamento', que se aplicam tanto à parte narrativa da fábula como à moralidade, criando o efeito de uma obra inteiramente didáctica e sem grandes concessões à vertente de entretenimento nem a elaborações estilísticas que carreguem uma marca de autor. Todas estas características das fábulas no Esopo português concorrem para atenuar a marca da figura autoral que está presente no prólogo, e criam, entre o prólogo e as fábulas, uma separação mais profunda do que acontece na generalidade dos livros de fábulas baseados na tradição do Anonymus Neveleti,

\footnotetext{
${ }^{8}$ É excepção a fábula 49, "Os atenienses e o seu rei", que entra abruptamente na narrativa.
} 
distinção esta que poderá ficar a dever-se à provável origem eclesiástica do redactor do nosso fabulário, que foi sublinhada tanto por Vasconcelos (1906: 102)e por Keidel (1908: 89) como, mais tarde, por Calado (1994: 15 e 20). Porém, tal não elimina a força de unidade que é conferida à colecção pela autoria biográfica inserida no prólogo do Livro de Exopo.

\section{A TRADIÇÃO DA “VIDA DE ESOPO" NA VIDA E FÁBULAS DO INSIGNE FABULADOR GREGO ESOPO DE MANUEL MENDES DA VIDIGUEIRA}

A colecção de fábulas intitulada Vida e Fábulas do Insigne fabulador grego Esopo, de novo juntas \& traduzidas com breves aplicaçoens moraes a cada fábula por Manuel Mendes da Vidigueira foi publicada pela primeira vez em Évora, por Manuel de Lyra, em 1603. Desta edição não me foi possível, até ao momento, encontrar rasto a não ser algumas breves referências em catálogos 9 . Do tradutor, também muito pouco se sabe além do que Barbosa de Machado regista na sua Biblioteca Lusitana (1752: 308-309), e que foi retomado pela crítica de uma forma geral. Segundo esta fonte, trata-se de um erudito oriundo da vila alentejana da Vidigueira que terá ensinado letras humanas, filosofia e preceitos de gramática da língua latina em Sevilha, em várias terras do Alentejo, e no Algarve, na cidade de Lagos, por ordem do Bispo do Algarve D. Fernão Martins Mascarenhas. Também é referido que traduziu Diodoro Siculo e que compôs o Discurso em louvor da Arte de Grammatica addicionada pelo P. Antonio Velez e o Romance ao Numero Ternario, em coplas. Não me deterei aqui na fortuna notável que teve a sua colecção de fábulas, mas fixar-me-ei naquilo que a distingue do livro de fábulas medieval de que acima tratei no que se refere às marcas da vida de Esopo.

Na realidade, esta é a primeira colecção em língua portuguesa a incluir a Vida de Esopo, que lhe serve de prólogo. Sigo, aqui, a orientação de Jeanne-Marie Boivin (2001: 69-87) que considera como um prólogo a Vida de Esopo que antecede a colecção de fábulas de Julien Macho. Nesta medida, esta colecção é também a primeira impressa em Portugal a seguir a tradição, que muito se difundiu na Europa a partir do último quartel do século XV, que faz acompanhar os livros de fábulas deste texto (Perry, 1933). A Vida de Esopo nesta colecção tem muitos traços de semelhança com outras 'Vidas de Esopo' que se propagaram com base na tradução de Remicio (1448), e é certamente baseada nesta tradição narrativa, mas apresenta, também, algumas particularidades que são dignas de nota.

Em primeiro lugar, nota-se um número consideravelmente mais reduzido de episódios na Vida portuguesa do que na generalidade das traduções elaboradas a partir da de Steinhöwel, que tomou por base a versão latina de Remicio, referindo-me essencialmente a duas: a de Julien Macho (Lyon, 1480) e a que está incluída no Esopete ystoriado (Toulouse, 1488). Não só os episódios são em número menor como também são bastante menos desenvolvidos. No entanto, a diferença mais significativa está no peso muito inferior, ou mesmo nulo, dado pelo fabulário português às fábulas na Vida de Esopo. Surpreendente a ausência de fábulas na tradução de Manuel Mendes,

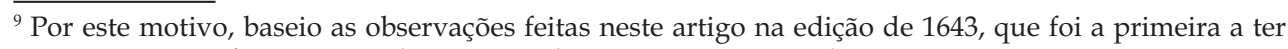
repercussão significativa, que chegou a ter dimensão internacional. 
enquanto na tradição de Steinhöwel surgem várias fábulas a pontuar a biografia de Esopo, geralmente inseridas na fase final desta. Assim, a primeira fábula proferida por Esopo na Vida de Julien Macho, é a do acordo de paz entre os lobos e as ovelhas $(M 55)^{10}$, e é narrada num momento crucial do conflito entre os Sâmios e o rei Creso para advertir os primeiros dos perigos de se separarem do seu maior trunfo, ou seja, o próprio Esopo, o conselheiro que já os tinha conduzido à vitória em várias ocasiões. Depois desta, Esopo narra mais cinco fábulas, sempre oferecidas como conselho e como prova da sua sabedoria ${ }^{11}$. A ligação entre a narração das fábulas por Esopo e a sua capacidade para decifrar os enigmas serve para demonstrar cabalmente que a fábula se enquadra nas técnicas do domínio da palavra. Nessa medida, a 'Vida...' tem como função na colecção de fábulas manifestar as excepcionais qualidades discursivas e interpretativas de Esopo, e assim fica justificada a sua autoria das fábulas.

Este programa de autorização de Esopo através da sua biografia é muito claro tanto na 'Vie d'Ésope' na colecção de Macho como na 'Vida del Esopo' no Esopete ystoriado. Mas a tradução de Manuel Mendes da Vidigueira, que é muito mais abreviada, não poderá ser considerada no mesmo patamar daquelas no que se refere à representação de Esopo como figura autoral. Não tendo meios suficientes para identificar a fonte directa da tradução da Vida de Esopo para português, resta-nos compará-la com outros exemplos desta tradição narrativa de onde ela proveio indubitavelmente.

A primeira ausência digna de nota na Vida de Esopo em português é a do episódio em que Esopo recupera a fala. Na economia narrativa deste texto nas outras versões, esta é uma etapa fundamental da biografia do protofabulador, na medida em que ela justifica e sublinha a relação específica com a palavra que ele irá desenvolver ao longo do seu percurso de vida e que culminará com a sua morte, também provocada pelo seu uso temerário das palavras. É importante notar que neste episódio aparecem certas marcas do maravilhoso, nomeadamente através da intervenção divina da deusa da Hospitalidade (M 6) ou a deusa da piedade e da caridade (EY 3) que atribui o dom da fala a Esopo, marcas estas que são totalmente ignoradas pelo tradutor português. Ainda na perspectiva da construção da competência oratória do autor de fábulas, é de assinalar outra ausência na colecção de Manuel Mendes, o episódio das línguas, que também está intimamente relacionado com o domínio da palavra (M 32-35 e EY 13). Note-se que A vida del Esopo no Esopete Ystoriado tem uma carga de fábulas superior à da colecção de Macho, que são apresentadas não só através da narração, mas também da alusão (p.e. a alusão à fábula do galo e da pedra preciosa na parte introdutória), e, ainda apresenta uma acentuada tendência para a teorização da fábula (Burrus e Goldberg, 1990). Na Vida... da colecção de Manuel Mendes, por outro lado, encontramos muito poucos vestígios desta tónica na fábula, que se limita a uma breve referência, no momento da sua libertação, ao livro de fábulas composto por Esopo que o tradutor apresenta:

\footnotetext{
${ }^{10}$ As fábulas da 'Vie d'Ésope' na colecção de Julien Macho serão sempre indicadas pela sigla $M$, as fábulas da 'Vida del Esopo' do Esopete ystoriado, pela sigla EY e as fábulas da 'Vida de Esopo' de Manuel Mendes da Vidigueira pela sigla $M M V$.

11 "O rato e a rã" (M 70), "a jovem a quem meteram o sentido no corpo" $(M 73)$, "o homem que nunca tinha estado na cidade" (M 73 ) e "a rapariga que foi violada pelo pai" (M 74).
} 
Outros muitos casos succederaõ a Esopo com Xanto, que deixo por brevidade, até que veio a ser livre, \& governar a Samo, conde compos em lingua Grega este volume de fabulas, com outras muitas obras, que ainda nam foram traduzidas. (Mendes da Vidigueira, 1643: 6).

A narração de fábulas é, pois, esbatida e, em seu lugar, é salientado o talento de Esopo para a decifração de enigmas, sem que estes, no entanto, sejam explicitamente associados à fábula. Porém, esta qualidade do Esopo decifrador de enigmas é referida na sequência da sua libertação, o que, implicitamente, associa à liberdade o desenvolvimento do domínio da palavra.

Naturalmente, ao referir expressamente que as fábulas "ainda naõ foraõ traduzidas", o tradutor procura enaltecer a sua tarefa, apresentando a tradução como um gesto de refundação do género da fábula numa outra língua, o português. Assim, a tradução das fábulas de Esopo a partir do grego, além de ser referida no texto da 'Vida...', é também anunciada no título em várias edições desta colecção: Vida e fábulas do insigne fabulador Grego Esopo de novo juntas e traduzidas com breves aplicações moraes a cada fábula (1643) ou Fábulas de Esopo, traduzidas da língua grega, com aplicações moraes a cada fábula, por Manuel Mendes da Vidigueira (1778). Não temos meios que possam comprovar que a tradução de Manuel Mendes da Vidigueira se tenha, efectivamente, realizado com base num modelo grego, apesar de as funções que exerceu poderem indiciar uma razoável familiaridade com os autores clássicos numa época em que o conhecimento dos gregos estava em franca expansão na Europa ocidental. A avaliar pelas estratégias de confirmação autoral assentes na figura de Esopo, parece lícito conjecturar que esta forma de apresentar a tradução tenha tido como objectivo acentuar o gesto de remissão para uma origem remota da fábula, próxima da figura do Esopo inventor da fábula. Assim, afigura-se-nos muito possível que a tradução de Manuel Mendes tenha sido elaborada, não directamente do grego, mas com base num modelo latino, por sua vez traduzido do grego, o que me parece corresponder a uma linhagem de tradução mais próxima do que se praticava desde o século XV na Europa, fundamentalmente a partir da vulgata de Planudes (Perry, 1933). Efectivamente, tudo leva a crer que o erudito português não tenha tido conhecimento da colecção medieval em língua portuguesa, apesar de se pensar que o manuscrito 3270*, que a conservou, ainda estaria em Portugal no século XVII (Calado, 1994: 22), e que ele genuinamente acreditou estar a realizar a primeira tradução das fábulas de Esopo para o português.

Mas, se na colecção em português de seiscentos a tradução é um gesto que se junta às demais estratégias de autorização da fábula, a verdade, porém, como vimos, é que a ligação da Vida de Esopo à colecção de fábulas é aí consideravelmente ténue, existindo entre as duas partes do volume uma distinção da matéria narrativa bastante mais vincada do que nas colecções que a antecederam. Assim, embora haja uma remissão para a biografia do fabulador no epimítio da fábula 'Juno e o pavão', as fontes invocadas, sempre nos epimítios, são, sobretudo, clássicas ou de cunho renascentista: (três referências a Horácio; duas a Marcial; duas a Baptista Fulgoso; uma a Mimo Publicano; uma a Appinio Polibo; uma a Aulio Gelio; uma a Alciato, e, ainda, uma referência mitológica ao sábio Ulisses) ${ }^{12}$. Ao mesmo tempo, estas referências surgem, 
por vezes, para confirmar o tempo presente e para implicar o sujeito da enunciação na fábula através da moral, como acontece no epimítio da fábula 'o lobo e o grou' que começa assim: “Diz Mimo Publicano [...] e eu assim o entendo" (MMV, XVII).

Podemos concluir que a inscrição da Vida de Esopo na colecção de fábulas traduzida por Manuel Mendes da Vidigueira no início de seiscentos obedece a convenções literárias consideravelmente distintas das que nortearam a inclusão de elementos biográficos do protofabulador nos livros de fábulas tardomedievais. Esopo não se apresenta textualmente de modo tão acentuado como um mestre nas artes da palavra, nem como uma autoridade intradiegética potenciadora, num nível metapoético, de outras auctoritates referidas nos prólogos ou nas fábulas. Neste caso, a sua marca autoral recua na Vida e, mais ainda, nas fábulas, onde surgem outras modalidades concorrenciais de garantir a legitimidade do género.

\section{BIBLIOGRAFIA}

Adrados, F. R. et alii (eds.) (1984). La Fable. Huit exposés suivis de discussions. Fondation Hardt, Genève.

Biscéré, A. (2009). “Les fables d'Esope: une oeuvre sans auteur?”, Le Fablier, 20: 9-25.

Boivin, J.-M. (2001). “La Vie d'Ésope: un prologue original d'un recueil de fables de Julien Macho", Reinardus, 14: 69-87.

Boivin, J.-M. (1998). “Prologues et épiloques des isopets", Reinardus, 11: 3-23.

Brun, L. (2004). "La voix du fabuliste médiéval à travers les isopets", PRIS-MA, 1-2: 23-40.

Burrus, V. A. and Goldberg, H. (eds.) (1990). Esopete ystoriado (Toulouse 1488), Madison, The Hispanic Seminar of Medieval Studies.

Calado, A. de A. (1994). Livro de Exopo. Coimbra: Separata do Boletim Bibliográfico da Biblioteca de Coimbra, 42.

Crosas, F. (ed.) (2002).«Vida y costumbres de los viejos filósofos». La traducción castellana cuatrocentista del "De vita et moribus philosophorum», atribuído a Walter Burley. Madrid, Editorial Iberoamericana Vervuert.

Keidel, G. C. (1901). “Notes on Aesopic Fable Literature in Spain and Portugal During the Middle Ages". Zeitschrift für Romanische Philologie, 25: 721-730.

Keidel, G. C. (1902). "Notes on Fable Incunabula Containing the Life of Aesop", Byzantinische Zeitschrift, 11, 2: 461-467 [Reprint: 2009]

Keidel, G. C. (1908). “O Livro de Esopo: fabulário português medieval, Lisboa, 1906”, Zeitschrift für romanische Philologie. Halle: 88-95.

Knust, H. (1886). Liber de Vita et moribus philosophorum poetarumque veterum ex multis libris tractus nec non breviter et compendiose per venerabilem virum magistrum Walterum Burley compilatur incipit feliciter, mit einer altspanischen übertsetzung der 
Eskurialbibliothek herausgegeben vom Tübingen: Bibliothek des litterarischen Vereins in Stuttgart, 177.

Machado, D. B. de (1752). Bibliotheca Lusitana, historica, critica e cronologica, na qual se comprehende a noticia dos Authores Portuguezes, e das Obras, que compuserão desde o tempo da promulgação da Ley da Graça até ao tempo prezente, Offerecida à Augusta Magestade de D. João V nosso senhor por Diogo Barbosa Machado III. Lisboa, Oficina de Ignácio Rodrigues.

Maia Junior, J.A. (1993). Fabulário medieval português. São Paulo, Universidade de São Paulo - Faculfade de Filosofia, Letras e Filosofia Humana.

Mélanges E. Picot I (1913). Paris, D. Morand.

Meyer, P. (1907). “O Livro de Esopo, fabulário português”, Romania, 36: 155-156.

Perry, B.E. [trad.] ([1965] 1990). Babrius and Phaedrus. Harvard University Press, The Loeb Classical Library.

Perry, B.E. (1933). “The Text Tradition of the Greek Life of Aesop”, Transactions and Proceedings of the American Philological Association, 64: 198-244.

Schaeffer, J.-M. (1995). “Aesopus, auctor inventus”, Poétique, 63: 345-364.

Schoettke, S. (1996). “De la 'source' à 'l'envol'. Ésope et Socrate dans le dispositif liminaire des Fables (1668) de La Fontaine", Revue de littérature comparée, $\mathrm{n}^{\mathrm{O}}$ spécial "La Fontaine et la fable": 45-68.

Dijk, G.-J. van. (1995). “The fables in the green life of Aesop”. Reinardus, 8: 131-150.

Dijk, G.-J. van. (1993). “Theory and Terminology of the Greek Fable”. Reinardus, 6: 171-183.

Vaganay, H. (ed.) (1913). “La mer des Histoires. Vingt fables d'Esope, traduction en français du XVe siècle", in Mélanges E. Picot (1913). I. Paris, D. Morand: 67-82.

Vasconcelos, J.L. de (ed.) (1906). O Livro de Esopo: fabulário português medieval. Separata da Revista Lusitana (1906), 8 e 9.

Vincent de Beauvais (1624 [Reprt: (1965). Akademische Druck/U. Verlakstalt, GrazAustria]). Speculum Historiale 2, Douai, Balthazar Bellère pour les Bénédictins de Douai: $87-90$

West, M.L. (1984). “The Ascription of Fables to Aesop”, in Adrados, F. R. et alii (eds.) (1984). La Fable. Huit exposés suivis de discussions. Fondation Hardt, Genève: 105135.

\section{CORPUS DE ANÁLISE}

Calado, A. de A. (ed.) (1994). Livro de Exopo. Coimbra: Separata do Boletim Bibliográfico da Biblioteca de Coimbra, 42.

Mendes da Vidigueira, M. (1643). Vida e fábulas do insigne fabulador grego Esopo. De novo juntas e traduzidas com breves aplicações morais a cada fábula. Lisboa, António Alvarez. 


\title{
DE FÁBULAS Y BESTIARIOS: \\ LA ESTÉTICA DE LOS ANIMALES EN LA EDAD MEDIA
}

RICARDO PIÑERO MORAL

Universidad de Salamanca $^{1}$

\begin{abstract}
Resumen:
Los animales en la Edad Media pueden ser considerados como un elemento de sentido que transciende los límites de su condición biológica. Desde el punto de vista filosófico no sólo ofrecen una virtualidad extraordinaria por lo que respecta a su aspecto formal, sino que presentan y representan un conjunto de valores que nos permiten establecer puntos de encuentro entre los diversos ámbitos de la cultura. Arte, teología, literatura, filosofía, biología... tienen en su horizonte la imagen del animal como un referente privilegiado para llegar a comprender el sentido de la realidad y del propio ser humano que la habita. Palabras clave: Estética, animales, Edad Media, bestiario
\end{abstract}

\begin{abstract}
:
The animals in the Middle Ages can be considered an element of sense that overcomes the limits of his biological condition. From the philosophical point of view not only they offer an extraordinary virtuality for what it concerns to his formal aspect, but they present and represent a 'corpus' of values that allow us to establish points of meeting among the diverse areas of the culture. Art, theology, literature, philosophy, zoology... have in his horizon the image of the animal as a modal favoured to manage to understand the sense of the reality and of the human being who lives it.
\end{abstract}

Key words: Aesthetics, animals, Middle Age, Bestiary

\section{DE LA REALIDAD DE LAS BESTIAS AL SENTIDO DE LAS IMÁGENES}

El arte medieval en su conjunto nos ofrece una zoo-teca incomparable. Aquellos que trabajamos directamente con pergaminos y vitelas disfrutamos cada día de ella. No importa si el escenario es un Libro de Horas de tal o cual reina o una copia miniada de la Naturalis Historia de Plinio... Esta presencia de lo animal acaece tanto si el manuscrito pretende ser transmisión de un texto sagrado o un inventario de madura y objetiva ciencia profana. Incluso a veces, el arte medieval es tan poderoso (tan virtual...), que es capaz de unir en una sola miniatura, la muy pura Anunciación de la Virgen María

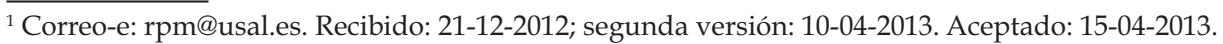


-en cuyo suceso suele aparecer, además, un animal específico, la paloma como Espíritu Santo- con una escena profana en la que un pequeño sátiro -símbolo de la lujuria más profana pensable- toca, displicente y burlón, un laúd ${ }^{2}$. Ahora bien, tal vez si los animales ocuparon los márgenes de los manuscritos ${ }^{3}$ es porque, en realidad, jugaban un papel central en la cultura del medioevo.

El mundo de los animales medievales ${ }^{4}$ es, preferentemente, el mundo de las imágenes de los animales. Éstos están más al servicio didáctico que bajo la mirada del interés científico. Porque su ser 'imagen' les convierte en un tipo especial de entidades. Los hombres del medioevo se los apropian, los devoran al hacer de ellos inteligencia, imaginación, memoria. Los animales en la Edad Media ${ }^{5}$ son más una creación humana que divina, como si la acción adánica de la denominación los hubiera convertido en una posesión más del hombre. En la imagen del animal medieval prima más su construcción simbólica que cualquier otra motivación, ya sea ésta biológica o incluso estética. Aspecto natural y artístico están al servicio de su sentido.

Los textos medievales como Beatos, leyendas, fábulas o bestiarios son el reflejo de una apropiación o si se quiere de una subversión en el mundo de la naturaleza, que tiene como fin el establecimiento de una hermenéutica con un poder especial, consistente en convertir a los animales en espejo de los seres humanos. El pensamiento estético medieval genera, de este modo, una inversus mundi ${ }^{6}$, y si no somos conscientes de ella y no la aplicamos -de la misma manera que un miope utiliza sus lentes- jamás llegaremos a entender aquello que se nos presenta, patentemente, ante nuestros ojos.

Los animales, en cuanto imagen, parece que son directos, inmediatos, pero su presencia ontológica, digamos, no es equivalente a su semántica iconológica. La dificultad de esta inversión del mundo radica en que un ser de apariencia, más o menos similar, puede desplegar diferentes significados según el lugar, la época y, en general, el contexto en el que se sitúa. Del mismo modo que una palabra puede tener varios significados simultáneos o sucesivos, la imagen de un animal puede ser vehículo de ideas y valores no sólo diferentes, sino absolutamente opuestos. Este principio de inversión, que convierte el mundo natural en un complejo y polisémico universo de sentidos, ha de ser tenido en cuenta como un dato previo a la hora de pensar el animal en la Edad Media7.

Una de las inversiones a la vez más extrañas y mejor asumidas por el hombre es que, en las fábulas del medioevo, los animales hablan con toda naturalidad. Transferimos a los animales, apenas sin darnos cuenta, un patrimonio tan exclusivo como el lenguaje.

\footnotetext{
${ }^{2}$ Como puede verse en el Libro de Horas francés, miniado hacia 1475 por Jean Fouquet, que se conserva en la Biblioteca Real de Copenhague, con la signatura Gl. Kgl. Saml. 1610 4º f 40r.

${ }^{3}$ Tesnière, M. H. (2004)

${ }^{4}$ Benton, J. R. (1992)

${ }^{5}$ Salisbury, J. E. (1994).

${ }^{6}$ Cf. Curtius, E. (1973: 94-98)

${ }^{7}$ Cf. Flores, C. (ed.) (1996).
} 
En esa transmisión lingüística se incluye, además, la capacidad de pensar y razonar, de tal manera que cualquiera de los personajes de una fábula no sólo expone de viva voz aquello que desea, sino que además lo hace siguiendo un plan argumentativo preciso, convincente, retórico, en el mejor de los sentidos, pues es capaz de aunar pensamiento y dicción de un modo cualificado. Nadie se extraña del discurso pausado y bien medido de un zorro o de un asno -por poner casos de animales no muy bien vistos por la idiosincrasia de su 'carácter' -, sin caer en la cuenta de que en esa transposición lingüística va, en el fondo, todo el 'genoma' del ser humano, todo aquello que, hasta entonces, nos hacía diferentes a las bestias, todo aquello que nos servía para construir nuestra identidad. Las fábulas humanizan los animales para hacer ver al hombre su propia animalidad.

Los bestiarios no dan la voz a los seres que los pueblan ${ }^{8}$. Todo lo más atribuyen a algunos de ellos la capacidad de hablar, como al loro ${ }^{9}$ tontorrón o a la perversa mantícora ${ }^{10}$. En ellos la puesta en escena cambia. Sustituyen la transferencia lingüística por la icónica. Un bestiario para mostrar la naturaleza de un animal está atado a la imagen, como el personaje de una fábula lo está a su voz. A través de su representación, la bestia nos cuenta cómo es, cómo se comporta, cuáles son sus hábitos, sus gustos, sus miedos; eso sí, lo hace sin abrir la boca. Quienes hablan en un libro de bestias son la imagen y el 'experto' -en su doble condición de naturalista y moralista-, pero lo hacen de una manera muy peculiar: sólo porque los bestiarios antropologizan al animal invierten su mundo-, tras la descripción física pueden sacar consecuencias morales, tanto de su naturaleza como de su comportamiento.

\footnotetext{
“Los historiadores de las ciencias nunca se han preguntado por qué la historia natural no había realizado ningún progreso en la Edad Media. La razón esencial estriba en que los teólogos la sustituyeron por el simbolismo animal. En los escritos medievales, la historia natural, como en las fábulas de La Fontaine, es sólo un capítulo de la moral. No hay ninguna diferencia entre el naturalista y el moralista, porque los animales no se estudian ni en sí ni por sí mismos, sino como esbozos o reflejos del hombre, centro de la Creación, para el cual el mundo animal ofrece un espejo, a la vez de aumento y deformante, de su propia naturaleza, la imagen o la caricatura de sus pasiones, virtudes y vicios" 11 .
}

Así, la Edad Media acoge la naturaleza animal como un punto relevante tanto para la reflexión filosófica como para la representación plástica, haciendo de las bestias un paradigma de comprensión del ser humano que les pone el nombre ${ }^{12}$. Se genera, de este modo una especie de familiaridad ${ }^{13}$ que aportará una vía de análisis de gran riqueza hermenéutica. El universo cultural del medioevo está poblado por infinidad de animales, no sólo por el trabajo fundamental que desempeñan en los trabajos de

\footnotetext{
${ }^{8}$ Payne, A. (1990).

${ }^{9}$ El psittacus que aparece en uno de los bestiarios medievales que se conservan en la Biblioteca Real de Copenhague resulta un ejemplo incuestionable (Gl. Kgl. $16334^{\circ}$, f 33v).

${ }^{10}$ Cf. Rochester Bestiary en la British Library de Londres c. 1230 (Royal MS 12 F xiii).

${ }^{11}$ Réau, L. (2000: 96).

${ }^{12}$ Gl. Kgl. $16334^{\circ}$, f $21 v$.

${ }^{13}$ Délort, R. (1984: 289).
} 
la agricultura, sino también como auténticos compañeros del hombre en otras tareas como la caza, sin olvidar que constituyen una base alimenticia para el ser humano. Pero lo que me interesa mostrar es que la interacción con los animales configura la experiencia del mundo que el hombre posee ${ }^{14}$. La percepción de la naturaleza animal ayudó a los hombres medievales a construir la imagen del mundo y se sirvió de ellos para dotar de un sentido más amplio a su propia condición, como seres creados por un mismo Dios.

Animales reales o imaginarios... una distinción cuya competencia no se funda en su efectividad. Para el naturalista o el moralista, lo fundante de la relación con el animal no es un criterio ontológico de existencia real, sino la relación especular que puede ser trazada entre diferentes tipos de criaturas. El interés no radica en proyectar y financiar una expedición zoológica a Arabia, o a Etiopía, o a las lejanas tierras de la India para comprobar sobre el terreno la existencia de los seres de los que habla un bestiario como el Physiologus, ni en recorrer los mares del sur en busca de sirenas... ${ }^{15}$ La mentalidad medieval prefiere dar por sentada la 'realidad' de esas criaturas porque, existan efectivamente o no, el caso es que poseen una capacidad explicativa extraordinaria.

La literatura medieval, como por otra parte la literatura antigua, está plagada de reflexiones que nos llevan a una especie de etología comparada entre los animales y el hombre. Los cuentos, las narraciones, la poesía, retratan en innumerables ocasiones animales que actúan sobre la sensibilidad y la imaginación, y ofrecen un punto de vista alternativo que termina por presentar el comportamiento de los animales como si fuera el de los seres humano. ${ }^{16}$ Estos retratos comparados están en los claustros de los monasterios, en las fábulas, en los manuscritos miniados, en los sermones de los predicadores, es decir, están al alcance de todos, no importa su condición consagrada o laica, no es relevante el nivel cultural que se tenga, no discrimina entre la riqueza y la pobreza. Su nivel de implantación es tan amplio que a nadie le resulta ajeno establecer un parangón entre él mismo y los animales, entre sí mismo y lo otro de sí.

“Los animales tienen una historia. Pero participan también de la nuestra, porque los símbolos a los que les asociamos desde el albor de los tiempos son testimonio de nuestra propia concepción del mundo"17.

Fábulas, relatos épicos, bestiarios, son todos ellos punto de encuentro entre el hombre y el mundo, entre lo humano y lo animal. Aún más, los animales son el espejo, esa condición de objetivación necesaria a toda reflexión de segundo orden, en la que el factor meramente especular deviene desarrollo especulativo. Los animales se toman como una proyección necesaria que, por un lado, nos distancia de nosotros mismos permitiendo así una contemplación sosegada, distante, separada, pero, por otro, nos rebota, nos redirige la mirada hacia nosotros mismos, como si fuéramos el

\footnotetext{
${ }^{14}$ Baxter, R. (1998).

${ }^{15}$ Gl. Kgl. 1633 4 , f 40v.

${ }^{16}$ Gl. Kgl. 1633 4 , f 10v.

17 Tesnière, M. H.(2005: 10).
} 
auténtico punto de 'reflexión', el punto en el que el ir y venir del pensamiento genera conocimiento. Escrutar la sociedad, sus problemas, el régimen político, la historia, buscar el sentido del mundo... todas esas tareas se cumplen a la perfección en el examen de la relación hombre-animal.

\section{MARÍA DE FRANCIA Y ODÓN DE CHERITON: ANIMALES DE LA COR- TE Y LA IGLESIA}

Si exceptuamos el bestiario, cuando leemos los textos animalísticos medievales, paradójicamente, aprendemos relativamente poco sobre sus características biológicas, pero enseguida vemos lo que esos autores que los escriben pensaban sobre los hombres. A continuación expondré tan sólo dos ejemplos para hacer más sólida la afirmación que acabo de formular. Repasaremos dos compilaciones de relatos esenciales: las fábulas de María de Francia y las de Odón de Cheriton. Lo que les interesa a estos dos fabulistas es reflejar el contexto social de su época, las cuestiones políticas, el statu quo, pero desde dos puntos de vista diferentes respectivamente: la corte y la iglesia, dos colinas privilegiadas, en todos los sentidos, desde las que otear un amplio horizonte.

Estos dos autores comparten el hecho de retratar animales y presentarlos como trasuntos de la condición y del comportamiento humanos, y, además, esos animales que describen se convierten en la manifestación de valores y contravalores precisos, haciendo de la literatura, supuestamente fantástica, una guía de orientación para la realidad, supuestamente existente. Se pueden establecer dos grandes tipos de animales: aquellos que representan los valores más deseados, lo que les convierte en seres respetados y de una dignidad excelente -pongamos por caso el león-; y aquellos otros que son el contrapunto de la excelencia, que reflejan lo no deseado, pero real, del mundo que retratan -por ejemplo los perros-.

Nuestro lenguaje popular es heredero de esa catalogación axiológica. Cuando se quiere halagar la fortaleza, la virtud, la resistencia, la majestuosidad, automáticamente el animal que nos viene a la cabeza es -el lector estará de acuerdo conmigo-, el león. Por el contrario, cuando queremos insultar, injuriar, desprestigiar, rebajar la categoría de alguien, una de las expresiones más comunes incluye una comparación con el perro ${ }^{18}$. Estas vías especulares -que no menos especulativas, a pesar de aparecer fuera de los tratados filosóficos convencionales- se construyen y aplican por extenso en la cultura medieval. Pero veamos las aportaciones de los dos fabulistas mencionados.

María de Francia ${ }^{19}$ es, sin duda, uno de los referentes fundamentales de lo que podríamos denominar un génerofabulístico cortesano.Sufigura noes, lamentablemente, muy conocida. Podemos situarla en el siglo XII, y de cómo están escritos sus textos podemos colegir que tenía una buena formación en los clásicos -conocía sin duda a los autores griegos y romanos-. Probablemente vivió en la Inglaterra normanda y sus obras, tal vez fueran bien leídas en la corte de Enrique II y de su ilustrada esposa

\footnotetext{
${ }^{18}$ Woods, B.A. (1959).

${ }^{19}$ Spiegel, H. (ed. \& trans.) (1987); Cuenca, L. A. de (ed.) (1975).
} 
Leonor de Aquitania. La fecha de producción de sus fábulas puede fijarse entre 1155 y 1189. Todas sus historias (un total de ciento tres, todas en verso) terminan con una moralización y están basadas en las de Fedro y en tradiciones populares. Sobre la autoría no hay duda, pues en el propio texto podemos leer: María es mi nombre y soy de Francia.

Las fábulas de María trascendieron el escenario cortesano e influyeron en otros contextos. Sus relatos están escritos en francés, mientras que los demás relatos de la época lo estaban en latín. Tal vez este dato nos sirva para entender su rápida y buena difusión, pues se conservan un buen número de manuscritos, lo que avala, sin duda, la popularidad de esta colección de fábulas, aunque, bien es cierto que a sus textos se fueron añadiendo otros de diferentes autores ${ }^{20}$. Otro aspecto que facilitó su expansión es la habilidad misma de la autora, capaz de convertir textos clásicos muy firmes y severos, con demasiada verborrea, en relatos muy amenos, muy cercanos, que podían ser tomados como historietas para divertir en la corte, gracias a una particular forma de versificar, lo que revela una gran capacidad artística para presentar escenarios y protagonistas surgidos en épocas muy remotas, y hacerlos parecer adecuados a su momento histórico.

Odón de Cheriton ${ }^{21}$, nacido hacia 1185 en Inglaterra, en el seno de una familia de muy buena posición (Cheriton daba nombre a una de sus posesiones), se orienta hacia la vida consagrada. Es un clérigo que se forma en Inglaterra pero culmina sus estudios doctorándose en teología en la Universidad de París. Es un viajero incansable, recorre Francia y España, y conoce muy bien la vida monástica. Aunque no hay noticia exacta sobre su pertenencia a la orden del Císter, lo cierto es que en su obra -desarrollada en pleno siglo XIII- se detectan algunos aspectos que le podrían vincular con el ideario estético cisterciense, sobre todo en lo que respecta a la lucha contra los abusos y los excesos estéticos y políticos.

Mientras que a María de Francia le interesa ofrecer un espejo cortesano, las fábulas de Odón sirven de reflejo del mundo religioso que le circunda, de la sociedad eclesiástica que le rodea. Si en las fábulas de la autora francesa los animales eran cortesanos, en las del inglés son monjes y clérigos. Aunque uno y otro parten del tronco común de los fabulistas greco-romanos, se separan paulatinamente de ellos mostrando una identidad perfectamente diferenciada con respecto a sus predecesores. Veamos alguna de esas diferencias: en el mundo antiguo Esopo, por ejemplo, utiliza sus personajes como peones de un ajedrez que intentan criticar un orden social dado; el propio Fedro, en el siglo primero de nuestra era, define estrictamente las fábulas como una creación literaria que surge entre los esclavos para poder hablar con toda libertad y criticar todo aquello que consideran injusto.

Tanto en el autor griego como en el romano, los relatos animalísticos lo son como un instrumento encriptado "en el que tiene lugar una enseñanza moral y una sátira

\footnotetext{
${ }^{20}$ Keidel, G. C. (1909)

${ }^{21}$ Jacobs, J. C. (ed.) (1985); Cf. Sánchez Salor, E. (ed.) (1992: 207-276).
} 
social o política"22. Las fábulas de la antigüedad son un vehículo reflexivo a salvo de la censura y de la mirada directa de quien ostenta el poder. Sin embargo, en los siglos XII y XIII, cuando se restauran las fábulas clásicas, el poder civil y la iglesia las usan como un arma capaz de incidir en el comportamiento del pueblo, de la sociedad, de la comunidad. El cambio de perspectiva es evidente: los relatos 'fantásticos' pasan de ser un arma contra el orden establecido a ser un instrumento de ese poder para justificarse, para darse una carta de identidad y para mostrarse como la mejor opción de las posibles. Frente al criticismo clásico, la fábula medieval es una herramienta para mantener el estado presente de las relaciones, un instrumento de autoconservación, en el que, además, se ofrece toda una visión del mundo con unas jerarquías, unos roles, unas creencias y todo un sistema de valores.

En ocasiones, las fábulas de María han sido despreciadas y muy criticadas $^{23}$ por estas razones, porque servían como mecanismos de control del orden social y por haber perdido su capacidad de poner en tela de juicio las conductas de los que lo rigen; pero en todo caso, afirmaciones como éstas son demasiado generales, y en la literatura fabulística medieval también se pueden encontrar vetas de crítica muy fina contra los poderes políticos, las injusticias sociales y las arbitrariedades eclesiásticas, además de una magnífica adecuación de los personajes clásicos a un nuevo contexto.

María de Francia y Odón de Cheriton tal vez tengan una orientación más conservadora que la de Esopo o Fedro, pero tuvieron una capacidad de influencia muy semejante a la de sus predecesores. Fueron capaces de construir relatos que la élite de la cultura empleó para desempeñar sus tareas de gobierno político y religioso. La utilización de fábulas y narraciones se presta perfectamente para mostrar un mundo jerarquizado. Los animales responden muy adecuadamente para poder ofrecer una visión estratificada, ordenada y cualificada del sistema social que se quiera. Su validez es, me atrevería a decir, casi universal y universalizable, y además, cuenta con la ventaja que a la identificación animal el ser humano accede como por naturaleza, es decir, la acepta sin estridencias, como un modo natural de concebir su mundo.

En los cambios que los fabulistas medievales introducen en los relatos animalísticos se constata la transformación que se pretende realizar en la conducta de los hombres desde un punto de vista orgánico, social, comunitario. En una fábula antigua, cada animal representa a un ser humano, sin embargo en los versos de María, cada animal corresponde a un grupo social completo, ya sean estos los propios gobernantes o sus siervos. Un animal fuerte no representa a un individuo fuerte, sino a un tipo de individuo. La perspectiva es siempre globalizadora: el animal deviene tipo humano, no individuo, cada animal refleja el modo de ser de un grupo social: la nobleza, el rico, el siervo de la gleba, el pobre, haciendo posible una transposición de la particularidad del individuo a la totalidad de la clase a la que pertenece. Y es ella, María de Francia, la que decide escribir para un escenario, la corte, que alberga un tipo

\footnotetext{
${ }^{22}$ Tesnière, M. H. (2005: 127).

${ }^{23}$ Blackham, H. J. (1985); Henderson, A. C. (1981).
} 
de personaje, el poderoso, el encargado de organizar jerárquicamente todo un mundo de relaciones.

Este nivel globalizador es también en el que se basan los relatos de Odón. Su 'tipo' es el hombre de iglesia, y sus animales representan los intereses eclesiásticos, de modo paralelo a cómo lo ejecuta, en el ámbito cortesano, la fabulista francesa. Para el de Cheriton el concepto de jerarquía es fundamental, porque a partir de él despliega los caracteres de los personajes ${ }^{24}$. Su mundo es un todo bien ordenado, compacto, en el que toda posible fisura no es más que una amenaza de la que necesariamente hay que liberarse. Si en la corte se defienden valores como el poder y la fortaleza, en el horizonte eclesial serán la integridad y la compasión dos de los baluartes requeridos. Ambos garantizan la lealtad y la continuidad, dos condiciones de posibilidad de la existencia misma de la Iglesia. Desde la integridad y la compasión pueden ser combatidos el vicio, en cualquiera de sus grados, y la hipocresía. No es de extrañar que los predicadores encontraran en estos textos un apoyo de valor incalculable para presentar la religión como un lugar natural para el hombre.

\section{DE LA TAXONOMÍA ZOOLÓGICA A LA AXIOLOGÍA MORAL}

Tras la conversión de lo particular a lo general, de lo individual a lo colectivo, tan sólo restaba ser cautos a la hora de seleccionar los animales que iban a servir de correa de transmisión para los mensajes políticos, en un caso, y religiosos, en el otro. En virtud de la jerarquización, los animales protagonistas de las historias de María de Francia fueron, a su vez, clasificados como ejemplares para un determinado estrato. Había animales de clase alta y animales de clase baja, pero esta clasificación no se refiere a una división social en sentido estricto, sino a una diferenciación moral dentro de un mismo grupo social. En la excelencia, los puestos más elevados en la jerarquía son ocupados, como era de esperar, por el león o el águila. Aún así éstos tienen siempre un antagonista bien definido.

En su descripción del buen rey María lo compara con el águila, mostrando a este ave como un ser magnánimo, glorioso, especialmente valeroso y muy digno. Cualidades todas ellas que ha de poseer un gobernante realmente noble, por su condición social y moral. Por su parte, el león representa también al buen rey, a aquél que ejerce su potestad con magnanimidad y justicia, representa a la nobleza por su rango 'natural'. Pero, como contra-símbolo, el rey injusto, despiadado, que se aprovecha con malas

\footnotetext{
${ }^{24}$ Uno de los casos en los que la jerarquía se tematiza de manera más explícita es el de la fábula Sobre la cigüeña y el lobo: "Una vez un lobo estaba casi ahogado con un hueso. Buscó un médico. Le dijeron sus siervos: <<La cigüeña tiene un largo pico y podrá sacar el hueso de la garganta.>> Mandó buscar a la cigüeña, prometiéndole una gran recompensa. Vino la cigüeña y le sacó el hueso. Ella pidió la recompensa. El lobo no le quiso dar nada, diciéndole: << ¿Acaso no pude matarte, cuando tenías tu cabeza metida en mi boca? ¿No te es suficiente que te haya dejado seguir viviendo?>> De la misma forma, los campesinos y pobres, cuando sirven a alguien, no pueden esperar ninguna recompensa. Dice, en efecto, el señor: <<El hombre es mío; ¿no es ya mucho no desollarte y dejarte vivir?>>” (Sánchez Salor, E. (ed.) (1992: 228).
} 
artes de sus súbditos tiene como imagen al lobo, un animal malvado, glotón, asesino y terrorífico como pocos.

Entre los antagonistas más renombrados en las fábulas medievales encontramos al zorro $^{25}$, un animal cuya popularidad atraviesa los relatos y los siglos. Como predador representa un status social elevado. Ciertamente no tiene la fuerza del león ni la ferocidad del lobo, pero su astucia lo convierte en un paradigma de especial interés en la explicación de la naturaleza humana. Para ser cazado se requieren muchos perros que sigan su difícil rastro. Su ingenio es inmenso, y queda bien plasmado en las fábulas, en los relatos épicos y en los bestiarios. María de Francia lo menciona en once de sus historias moralizadas en las que nos lo presenta como un icono de del mal, de la pobreza, del engaño y de la hipocresía.

La jerarquización social, política y religiosa, entre poderosos y súbditos, entre predadores y presas, no puede obviar la incorporación en el relato el punto de vista de las víctimas. Si bien es cierto que el interés medieval -y el número de páginas es un dato que lo corrobora- se centra más en el poderoso, también las víctimas aparecen en escena, aunque sea de manera marginal. Entre ellas, el gallo, el cordero, el asno, el perro... De ellas siempre se nos ofrece una opinión muy desfavorable, se retratan, muchas veces, como criaturas estúpidas, ingenuas y la propia fabulista las desacredita, sobre todo, cuando intentan progresar en el orden social establecido. En las fábulas de la poetisa francesa los cambios de clase son impensables, y, no sé hasta qué punto, indeseables.

La perspectiva de Odón respecto a las víctimas es diferente, tal vez por su innegable orientación pastoral ${ }^{26}$, lo que le impide tratar con desdeño a los pobres y a los menos favorecidos. Su interés, por el contrario, está en mostrar sus cualidades, unas virtudes de las que carecen, por lo general, todos aquellos cercanos a las riquezas -como nos recuerda, por ejemplo, el personaje que ocupa el centro en la representación del infierno del Beato de Silos en tetralóbulo-. Incluso hace un examen muy fino de las relaciones de servidumbre, como queda bien ejemplificado en una de sus fábulas en

\footnotetext{
${ }^{25}$ Odón identifica, en varias ocasiones, al zorro con el diablo. Destaca cómo es especialmente astuto su comportamiento incluso cuando se enfrenta al lobo, como en Sobre la zorra, el lobo y el cubo del pozo. El relato Sobre los engaños de la zorra y del gato marca la diferencia entre los que, para librarse del mal suben hacia lo alto -los fieles, representados, en esta ocasión por el gato-, y los que sólo quieren embaucar con sus ardides -los zorros- cuyo final es ser devorados por los perros del cazador. En Sobre la zorra compara su táctica de caza haciéndose la muerta, con la forma en que el diablo se finge muerto para atrapar las almas de los pecadores. De este comportamiento ladino y fraudulento da cuenta Sobre el engaño de la zorra, donde vemos cómo se camufla poniéndose una piel de cordero para meterse entre las ovejas y así saciar sus apetitos.

${ }^{26}$ La orientación pastoral y la defensa del hombre justo está magníficamente reflejada cuando narra los peligros que le acechan cuando se enfrenta al diablo, como en la fábula Del ave que se llama quebrantahuesos: "Hay un ave que se llama quebrantahuesos, freinos, porque con su pico quebranta los huesos y se come el sebo y el tuétano. Cuando por su dureza no puede romperlos, los lleva a lo alto y los deja caer sobre las rocas; y así los huesos se rompen. Así hace el diablo: cuando no puede romper a un hombre firme, le lleva a las alturas de los cargos y entonces le deja caer; así lo destroza totalmente; y cuanto más alto es el cargo, tanto más grave es la caída. El recorrido de una piedra es mayor cuando cae de lo alto que cuando cae de lo bajo. Así, los malvados reyes, los perversos obispos y los ricos sufren una caída mayor desde lo alto hasta el infierno que los pobres" (Sánchez Salor, E. (1992: 229).
} 
las que se narran las peripecias de un macho cabrío y un asno: la cabra engaña al asno para que sea su sirviente, éste se da cuenta y la aplasta:

"un macho cabrío se hizo una vez siervo de un asno y le vio sencillo y humilde. Subió encima del asno y pretendió cabalgar en él. El asno, airado, levantó las patas delanteras y cayó sobre la espalda del macho cabrío, y le aplastó y mató, diciendo: <<Aunque tu dueño sea un asno, no cabalgues sobre él.>> De igual forma, muchos ven a sus dueños sencillos, o ancianos, o ciegos o inhábiles; y les desprecian y se ríen de ellos" ${ }^{27}$.

La moraleja revela qué les sucede a los que no respetan a sus señores, sobre todo si fundan su relación en el engaño y en la burla. Qué forma tan sencilla de explicar las consecuencias de la rebelión del Adversario contra Dios ${ }^{28}$.

Pero la víctima por excelencia de los relatos medievales es el cordero. Cristo nacido como Cordero de Dios es sacrificado. Si Él, que es Dios, bajo la advocación de cordero, es inmolado, qué no le cabe esperar -temer- a aquellos que también son corderos, pero cuyo señor no el Señor. Cristo es, además, el Buen Pastor que atiende, cuida y da la vida por su rebaño. Por una lado, el simbolismo del cordero mantiene la excelencia de ser un sacrificio de redención para la humanidad, y el cristianismo medieval despliega como en ninguna otra época la virtualidad de esta imagen, basta con ver el tratamiento que de ella ofrecen, por ejemplo, San Francisco -cuya relación de empatía con los animales es bien conocida-, y San Buenaventura -que escribe con gran sensibilidad sobre la simbología de las Sagradas Escrituras-.

Si el papel natural del héroe en la literatura medieval era el de predador -el león y el águila ${ }^{29}$ lo son-, el papel de víctima estaba reservado para los perdedores. La única excepción es el cordero, cuando es el Cordero de Dios; una víctima, sí, pero que representa la máxima heroicidad y que posibilita la salvación de la humanidad. El combate entre lobos y corderos reproduce el combate del Maligno contra el Redentor, la lucha de las bestias del infierno contra los ángeles del cielo. María y Odón reflejan también este combate, en la corte y en la Iglesia, dos mónadas con puertas y ventanas desde la que se puede contemplar la realidad del mundo, aunque sea a partir de seres que no existan realmente, o que sean habitantes de otros reinos.

Las fábulas medievales, en realidad, nos ponen en el camino de examinar la sociedad, la justicia, el pensamiento, la religión, la civilización al completo; incluida la propia imagen especular del hombre, es decir, la propia visión del hombre sobre sí mismo, a la luz de un universo de criaturas creadas por el inmenso poder de Dios. A

\footnotetext{
${ }_{27}$ Sobre el macho cabrío a caballo, Ibíd., Sánchez Salor, E. (1992: 274).

${ }^{28}$ Cf. Piñero, R. (2005).

${ }^{29}$ Hemos de llamar la atención sobre el hecho de que estos dos animales tienen una ambivalencia contrastada en las fábulas de Odón, es decir, unas veces representan a Dios y otras al diablo. Se puede constatar, por ejemplo, cómo en el relato titulado Sobre la corneja el águila representa al rey justo, a Dios, mientras que en Sobre la tortuga y el águila ésta representa al mismísimo diablo. Así pues, la tarea hermenéutica ha de ser desarrollada con cautela, analizando cuidadosamente el sentido de cada animal en cada una de las fábulas. No cabe, por tanto, una interpretación global dado que nos conduciría a errores graves.
} 
Odón de Cheriton le obsesionaba justamente esa visión de Dios todopoderoso ${ }^{30}$, como una vía para comprender la realidad. Sus diseños alegóricos inciden justamente en ese intento de desvelar la naturaleza de las criaturas para evitar el error que nos hace caer en el abismo del infierno ${ }^{31}$.

En su arquitectónica literaria el fundamento no es la zoología, sino la Escritura, no olvidemos que era doctor en teología por la Universidad de París. Su creatividad no responde tan sólo al interés por el ejercicio artístico-literario, sino que se inserta en el intento de esclarecer la mente de los hombres para que conozcan los planes de Dios, y entablen un combate contra el diablo. Por eso nos habla de escarabajos ${ }^{32}$, de zorros, de $_{\operatorname{sapos}^{33}}$, transformando el juego literario en un servicio religioso en el que se intenta enseñar a discriminar el bien del mal, la verdad de la falsedad, el vicio de la virtud, el engaño del embaucador de la buena nueva del Cordero. Así escribe en la fábula titulada Sobre el engaño de la zorra:

“La zorra era tan conocida por las ovejas que éstas se guardaban mucho de ella, de forma que no salían de su redil ni se apartaban del perro que las guardaba. Pensó la zorra: <<Sé qué hacer; me pondré una piel de oveja y me introduciré entre las ovejas; entonces podré, aprovechando la ocasión, comer corderos y ovejas. >> Y así lo hizo. Así son muchos religiosos que tienen vestidos blancos de manera que parecen ovejas de Cristo. Estos son los falsos profetas que vienen con la piel de oveja, pero que por dentro son los lobos rapaces y zorras fraudulentas. Tales son los falsos monjes, los falsos predicadores, los falsos religiosos, que no buscan otra cosa de los ricos sino tierras, viñas, dinero y molestan a los que están a su lado más que a ningún otro. Por eso, yo prefiero tener por vecino a un pagano o a un judío antes que a un religioso así. Si yo creyera que los vestidos blancos me santifican, colgaría sobre mi cuello todo lo blanco que pudiera" ${ }^{\prime \prime 4}$.

La popularidad de las fábulas en la Edad Media y la definición ejemplar de los animales ayudó, de manera formidable, a la difusión no de simples narraciones, atractivas y sencillas de comprender, sino a la expansión de un modo de ver el universo y de contemplar el lugar que en él ocupa el ser que dio nombre a todos los animales. Los bestiarios, de este modo, se convierten en 'humanarios', y las fábulas en creaciones que nos permiten soñar con un mundo en el que nuestra capacidad de creación, nuestros deseos y nuestra libertad se realizan, es decir, pasan de la ficción a la existencia.

\footnotetext{
${ }^{30}$ En Sobre el hereje y la mosca Odón enseña que negar el poder creador de Dios no sólo es una herejía, sino que supone una destrucción total del apóstata.

${ }^{31}$ Como en Sobre las quejas de las ovejas al león contra el lobo, o Sobre los asnos vestidos con piel de león, o Sobre el ajedrez, o Sobre la mosca y la hormiga, y, sobre todo, en Sobre la búsqueda de la eterna felicidad por parte de Godero.

32 “De igual forma que el escarabajo bate sus alas ruidosamente, dando la impresión que dice: Frai bien, frai bien; y a la postre choca con tu rostro. Así dicen algunos: Frai bien, frai bien; prometen ungüentos y dan tormento; prometen rosas y dan ortigas" (Sobre el escarabajo, Sánchez Salor, E. (ed.) (1992: 226). Del escarabajo Odón dice, además, que es una criatura maldita y antinatural, porque "le sabe mejor el estiércol del pecado que Cristo, los lugares del diablo y el estiércol [...] que la vida y los ejemplos de los santos" (Sobre un escarabajo: 243), y termina haciendo referencia al Comentario a los Salmos de San Agustín -30, 2- cuando los compara con aquellos que tienen corrompido el paladar de su alma a causa de su fiebre de iniquidad.

${ }^{33}$ Sobre el sapo y la rana es una exposición directa y demoledora sobre el comportamiento de los avaros y los tacaños.

${ }^{34}$ Sánchez Salor, E. (1992: 257).
} 


\section{BIBLIOGRAFÍA}

Baxter, R. (1998): Bestiaries and their Users in the Middle Ages, Phoenix Mill.

Benton, J. R. (1992): The medieval menagerie: animals in the art of middle ages, New York.

Blackham, H. J. (1985): The Fable as Literature, London.

Cuenca, L. A. de (ed.) (1975): Lais. María de Francia, Madrid.

Curtius, E. (1973): European Literature and the Latin Middle Ages, Princeton: 94-98.

Délort, R. (1984): Les animaux ont une historire, Paris.

Flores, C. (ed.) (1996): Animals in the Middle Ages, New York-London.

Henderson, A. C. (1981): "Animal Fables a Vehicles of Social Protest and Satire: Twelfth Century to Henryson", en Goossens, J. \& Sodmann, T. (eds.) Third International Beast Epic, Fable and Fabliau Colloquium, Köln.

Jacobs, J. C. (ed.) (1985): The Fables of Odo of Cheriton, Syracuse.

Keidel, G. C. (1909): "The History of the French Fable Manuscripts", en Publications of Modern Language Association, 24 (1909): 218.

Payne, A. (1990): Medieval Beasts, London.

Piñero, R. (2005): Las bestias del infierno, Salamanca.

Réau, L. (2000): Iconografía del arte cristiano. Introducción general, Barcelona, vol. I: 96.

Salisbury, J. E. (1994): Animals in the Middle Ages, New York.

Sánchez Salor, E. (ed.) (1992): Fábulas latinas medievales, Madrid.

Spiegel, H. (ed. \& trans.) (1987): Marie de France: Fables, Toronto.

Tesnière, M. H. (dir.) (2004): Bestiaire au moyen âge: les animaux dans les manuscrits, Paris.

Tesnière, M. H. (2005): Bestiaire médiéval, Paris.

Woods, B.A. (1959): The Devil in Dog Form. A Partial Type-Index of Devil Legends, Berkeley. 


\title{
PRESENCIA Y ECOS DE FÁBULAS ESÓPICAS EN EL BALDO
}

TOMASA PASTRANA SANTAMARTA

Universidad de León ${ }^{1}$

\begin{abstract}
Resumen
El autor del Baldo nos presenta un libro de caballerías en el que la intención de entretenimiento no es menor que la de mostrar erudición y modelos de conducta apropiados en la sociedad, para ello introduce, al lado de las aventuras propias de estos libros, referencias a autores clásicos entre los que figura Esopo con alguna de sus fábulas recogidas en el Esopete ystoriado. En este estudio se ofrece una comparación de las fábulas esópicas que aparecen en ambos libros, se analizan sus variantes, distintas interpretaciones, así como el uso que el autor hace de las mismas en la obra: argumentar, dar consejos sobre modelos de conducta y mostrar las semejanzas en los comportamientos de hombres y animales.
\end{abstract}

Palabras clave: Baldo, Esopo, Esopete ystoriado, fábulas, versiones, libros de caballerías, didactismo, consejos, argumentación

\begin{abstract}
The author of Baldus presents us with a chivalric book in which the aim of entertainment is not of less importance than that of showing erudition and offering models for appropriate behavior in society. In order to get this objective the author combines the typical adventures from chivalric books with a myriad of references to classical authors among whom we find Aesop, whose fables had been compiled in the Esopete ystoriado. The present study offers a comparison of the Aesopian fables that are mentioned in Baldus with those appearing in the original text. We offer an analysis of the versions, their interpretation and the use the author of Baldus makes of them in his work: persuasion, advising about appropriate behavior, and pointing out the similarities between animal and human behavior.
\end{abstract}

Key words: Baldus, Aesop, Esopete ystoriado, fables, versions, chivalric books, didactic, advice, persuasion

\section{INTRODUCCIÓN}

La presencia de contenido didáctico en las obras del XVI era elemento necesario para que no fueran objeto de crítica por parte de los moralistas áureos. Aunque el valor didáctico de la lectura de hechos heroicos, verdaderos o no, ya había sido señalado en

${ }^{1}$ Correo-e: tomasap@hotmail.com. Recibido: 15-12-2012; segunda versión 26-02-2013. Aceptado: 15-032013. 
Las siete Partidas de Alfonso X y por otros autores como Feliciano de Silva o el propio autor del Baldo "¿Quién es de tan pequeña capacidad que luego no vea el provecho que le pueden dar las fábulas no perjudiciales?"2, esto no era óbice para que los críticos "estos severos Catones que quieren enviar las obras buenas, aunque fabulosas, a los infiernos con quien las hicieron" ${ }^{3}$ atacaran los libros de caballerías como lectura inútil . $^{4}$ Por eso se convierte casi en lugar común la alusión en los prólogos al carácter didáctico de estas obras a modo exculpatorio, en Baldo el autor dice que introduce enseñanzas de "filósofos morales para que tome algún provecho el lector a lo que va mi intención encaminada" 5 .

Martín Romero comenta que el entretenimiento en los libros de caballerías se ve "motivado por razones éticas, camuflado por ellas o, simplemente, mezclado con disquisiciones morales" ${ }^{\prime}$. Así, encontramos en el Baldo digresiones que recuerdan al sermón, aventuras caballerescas que sirven de modelo de comportamiento, pasando por citas de escritores antiguos y referencias cristianas. El presente trabajo introduce un elemento más a esta lista, la fábula esópica, cuya presencia está todavía sin estudio en los libros de caballerías. Se analiza ahora la presencia y el uso de tales textos en el Baldo con la intención de contribuir a abrir el camino a estudios similares en otros libros de caballerías.

\section{PRESENTACIÓN DE BALDO}

El Baldo, del que solo consta una edición fechada en 1542 en el taller de Domenico de Robertis, es el cuarto libro del ciclo Reinaldos de Montalbán. Esta obra tiene varias particularidades que la hacen distanciarse de los libros de caballerías al uso, en primer lugar y hasta el capítulo xxxv del primer libro se trata de una traducción de una obra italiana de 1521 del monje benedictino Teófilo Folengo que usa por seudónimo el nombre de Merlín Cocayo; por otro lado, no responde al patrón típico de los libros de caballerías pues en ella hay cabida para textos diversos que nos hacen recordar otros géneros que van desde el típicamente caballeresco a relatos que parecen anunciar la novela picaresca, pasando por reflexiones del autor y compilaciones de saber que recuerdan a misceláneas donde las obras clásicas conviven con las del renacimiento italiano y con textos de un carisma más popular que entroncan con las recopilaciones de fábulas esópicas y espejos de príncipes. Todo ello es fruto, como dice Lacarra, del "nuevo impulso que la literatura sapiencial cobra durante el humanismo" (2009: 323).

Aunque en su momento un libro de caballerías era todo lo opuesto a cualquier obra de la que se pudiera extraer ninguna utilidad, en el Baldo la intención didáctica

\footnotetext{
2 Baldo, pág. 4.

${ }^{3}$ Baldo, pág. 4.

${ }^{4}$ Sobre este tema ver Martín Romero, “Buenas doctrinas y enxemplos”. Aspectos sapienciales y didácticos en los libros de caballerías.

${ }^{5}$ Baldo, pág. 10.

${ }^{6}$ Martín (2004-2005).
} 
queda patente en estos comentarios que el autor añade a algunos de los capítulos y en los temas que ocupan capítulos enteros en los que el lector puede pensar haber cambiado de obra.

\section{TÉRMINO “FÁBULA"}

Siguiendo la definición de San Isidoro, las fábulas se oponen a todo lo que es verídico o histórico son "cosas non fechas, mas fingidas"7; son res fictae "Fabulas son aquellas cosas que ni son hechas ni pueden ser hechas, porque serían hechas fuera de la naturaleza" 8 frente a las res gestae "Las historias son verdaderas y así hechas como se cuentan" 9 .

En La vida de Esopo leemos:

Hay diversas fábulas, porque algunas son dichas "esópicas", las cuales hizo y compuso el muy clarísimo Esopo y son donde las animalias irracionales que no tienen habla son introducidas y fingidas que hablan ${ }^{10}$.

Y con estos dos significados usa el término el autor del Baldo como una historia ficticia opuesta a algo verídico incluyendo aquí ficciones, narraciones mitológicas y las fábulas tal y como las entendemos hoy, como corroboran estas citas: "No penséis que lo que nos cuenta Cíngar son fábulas. Esto es lo que yo vi y puede creerse"11; "Semejante es aquesto a la fábulilla de Isopo que cuenta del ratón ciudadano y del campesino"12.

\section{PRESENCIA DE FÁBULAS EN EL BALDO}

Al analizar las fábulas en el Baldo me centro tan solo en las "fábulas esópicas", dejando a un lado las simples menciones a animales que nos remiten a fábulas y obviando también otras con un carácter más oriental que recuerdan a las usadas para educar a príncipes, tales como la fábula del aldeano y el odre que Cíngar presenta en el capítulo XLI del Libro II del Baldo.

Así pues, tendríamos dos fábulas esópicas en el prólogo del Baldo: la raposa y las moscas; el caballo y el ciervo, además de una que inventa el propio autor: la de Ceres, la golondrina y la anguila. En el Libro I Falqueto presenta la fábula de la cogujada y la mies; dentro de los capítulos, el autor hace referencias a dos fábulas más: el perro y el trozo de carne; el león y la mosca. Y es en las anotaciones tras los capítulos donde se encuentra el mayor número de ellas: los dos ratones; el buey y la rana; la zorra y las peras; el cuclillo, el ruiseñor y el asno. Es decir, un total de 9 fábulas esópicas en toda la obra.

\footnotetext{
${ }^{7}$ Esopete Ystoriado, pág. 1.

${ }^{8}$ Esopete Ystoriado, pág. 2.

${ }^{9}$ Esopete Ystoriado, pág. 3.

${ }^{10}$ Esopete Ystoriado, pág. 1.

${ }^{11}$ Baldo, pág. 116.

${ }^{12}$ Baldo, pág. 168.
} 


\section{USO DE LAS FÁBULAS}

Bizarri (2011: 60) nos indica que ya Romulus a fines del siglo VIII o comienzos del IX hablaba del uso de las fábulas como modelo de conducta: "quid homines observare debeant. Verum ut vitam hominum et mores ostenderet": sirven, pues, para ofrecer "una forma figurada de representar las conductas humanas". En La vida de Esopo también se incide en esto:

E assi aquel que quiere leer este libro dela color dela flor, esto es dela fabula, non deve curar,
mas antes de la doctrina en ella contenida et inserta para adquirir y alcanzar buenas costumbres
y virtudes y para evitar y guardarse de los malos usos, chupando y tomando asi en vianda del
ánima y del cuerpo. (1)
El prólogo al primer libro del Esopete coincide con esto y añade además su tono lúdico:

Porque ayude y aproveche a la vida humana, el presente libro es compuesto a la manera de fábulas de reír, porque las cosas provechosas y necesarias mejor y más dulcemente se toman pintadas y fulcidas con cosas provocantes a risa y placer. (...) E la brevedad de las fábulas trae carga honesta de costumbres, como la cáscara seca cubre muchas veces el buen meollo. (33)

El prólogo al Baldo tiene un título muy significativo: "Prólogo sobre la poesía de Merlino Cocayo poeta Mantuano que demuestra cómo se ha de sacar utilidad de las fábulas y la causa por que se inventaron"13. Entendiendo aquí por "fábula" res ficticia y no solo en el sentido de "fábula esópica" aunque el autor también defiende las fábulas esópicas propiamente dichas: "las cuales claro está que muy poco daño traen porque ya se nombran por cosas falsas y la cosa clara no engaña"14.

También en el Baldo se señalan los dos usos anteriores a las fábulas: "dar exemplo a los humanos"15 entendiendo que hay que interpretarlas pues son una suerte de parábolas con un significado profundo y ayudan a decidir cómo actuar; el otro uso sería el atraer el ánimo y despertar el interés de quien escucha, siendo por eso buenas herramientas para trasmitir enseñanzas. Dice el autor en el prólogo en un pasaje que merece la pena transcribirse:

Asimismo las pusieron en sus obras grandes varones y celebérrimos filósofos como Platón, Aristóteles, Plutarco y Plinio porque son ellas de tal manera que penetran los ánimos de los lectores y con ciertas semejantes valen para conmover los ánimos de los hombres y de tal manera, que el oír las luengas oraciones e historias ordenadas enhastían, aunque sean de cosas provechosas, si no se entremeten estas fábulas. Seanos testigo un orador de Atenas que, orando delante del pueblo ateniense, como lo viese poco atento, rogóles que tuviesen por bien de oír una fábula. Ellos entonces dícenle que la diga y aguzan las orejas para oírla. Entonces él dice así: - Ceres, vuestra diosa -porque era allí adorada-, con la golondrina y la anguila yendo caminando, allegaron a un río. La golondrina lo pasó volando y la anguila nadando.

Como acabó el orador de decir esto, callóse un poco. Todos entonces comiénzanle a preguntar qué había hecho Ceres. Él respondió:

- Enojóse con vosotros vuestra diosa, porque no queréis oír las cosas provechosas pero muy atentos oís las consejas. (5)

13 Baldo,pág. 3.

14 Baldo, pág, 5.

15 Baldo, pág. 3. 
En el Baldo las fábulas se utilizan con tres intenciones: ofrecer un modelo de conducta, hacer comparaciones entre el comportamiento humano y el animal, y servir de argumento para defender una idea. Estas dos últimas ya las señalaban Burrus y Goldberg ${ }^{16}$.

A continuación presento un análisis de estos usos haciendo hincapié en las fábulas y su significado comparándolas con el Esopete Ystoriado, obra de 1488, que puede considerarse la fuente fabulística más conocida en la época.

\subsection{Uso como argumentación}

La mayor presencia de fábulas la tenemos en la "moralidad", "adición del trasladador" o "exclamación" con que concluyen alguno de los capítulos. Estos textos son creación propia del traductor del Baldo, que acude al tópico del manuscrito encontrado que no sólo traduce sino que decide enriquecer "y sabiendo bien que esto es fábula, metí también fábulas e historias antiguas" ${ }^{17}$ y continúa:

De adonde tuve por bien hacer al fin de los capítulos que fuesen menester sus adiciones sacadas de filósofos morales para que tome algún provecho el lector a lo que va mi intención encaminada, no como aquellos libros que solamente alegran y aún eso con gracias deshonestas. (9-10)

Estos elementos añadidos son reflexiones eruditas, repletas de citas a autores clásicos, personajes mitológicos y en ocasiones menciones a fábulas. El tema de los mismos se relaciona, con mayor o menor desenvoltura, con lo tratado en el capítulo, son comentarios al comportamiento de los personajes que incluso se someten a interpretaciones alegóricas en una clara intención didáctica de inculcar un comportamiento moralmente aceptado por la sociedad ${ }^{18}$.

La aparición de fábulas esópicas en estas adiciones responde a las necesidades del proceso argumentativo del autor que, para defender sus ideas, utiliza el apoyo de obras de escritores antiguos y, con intención de continuar un hilo discursivo, introduce las fábulas de Esopo sin considerarlas argumentos inferiores a las palabras de escritores clásicos consagrados, de hecho nos dice "más autoridad y provecho trae un refrán de los experimentados que un dicho de sabios"19.

\footnotetext{
${ }^{16}$ Aesopic fables are short illustrative narratives that illuminate some aspect of human behavior. In their literary realizations they are compiled with promythia or epimythia, or they are incorporated into a larger narrative where they either advance the action, describe the attributes of a character, or act as persuasive tools in discourse. Burrus y Goldberg (1990: viii).

${ }^{17}$ Baldo, pág. 8.

${ }^{18}$ Martin Romero señala el estudio de Cacho Blecua sobre el Amadís al respecto. No solo las acciones de los caballeros sino las de los propios dioses mitológicos eran objeto de interpretación alegórica con finalidad moral. Gernert citando a Jean Seznec (Los dioses de la Antigüedad en la Edad Media y el Renacimiento, Madrid, 1952, p.91) dice "los Dioses del Renacimiento continuaban siendo con mucha frecuencia, figuras didácticas incluso instrumentos para la edificación de las almas". (Genert: 2004: 90).

${ }^{19}$ Baldo, pág. 19.
} 
Dos veces hace mención a Esopo al presentar una fábula: la de los dos ratones y la de la zorra y las peras; en las restantes ocasiones bien se las atribuye a Horacio: la rana y el buey, o no se hace mención a la autoría.

\subsection{Uso en las moralidades}

Se usan para apoyar argumentos las siguientes fábulas:

La fábula de los dos ratones, que figura con el número XX en el Libro I del Esopete. Dos son los significados de esta fábula: por un lado defiende la pobreza frente a la riqueza, por otro critica a quienes se acercan a los poderosos para tener más de lo que les corresponde según su estado.

El autor del Baldo defiende la primera de las ideas, critica las riquezas de por sí, incluso las que se obtienen por el propio trabajo ya que el problema es la envidia que generan, por ello el que renuncia a los bienes es feliz. El autor sigue con agilidad la línea argumentativa del capítulo que cerraba con la historia de Arión y advierte contra los males que acarrea la posesión de riqueza. Se alude sólo al título de la fábula pues supone que el lector es conocedor de la misma.

Semejante es aquesto a la fábulilla de Isopo que cuenta del ratón ciudadano y del campesino, así que sólo aquel estaba descansado el que hubiere desechado las riquezas y no le pese de habérselas quitado otro. (I, 45.168)

La fábula de la rana y el buey también se usa para argumentar. Es la fábula XX del Libro II del Esopete. Comienza "si algún pobre quiere igualarse con algún poderoso, el tal se destruye y perece" termina con "Y por esto se dice: "no te hinches y no reventarás"(II.54). En una interpretación alegórica del capítulo precedente la nave de Baldo se equipara a la nave del mundo que navega por la vida. Los vientos son los vicios y el autor se centra en la ambición y es entonces cuando introduce la fabula del buey y la rana. Se produce un cambio ligero en el argumento con respecto al original pues se dice que el buey había matado a varias ranas antes de que una de ellas se enfrentara a él "la rana (...) como hubiese preguntado a un hijuelo suyo, que venía huyendo del buey que con los pies había trillado a sus hermanos" (I, 21.54), así el deseo de la rana nacería de un sentimiento de venganza. En la versión del Esopete se dice que el buey pacía en un prado cuando a una rana le entraron ganas de ser como él, el antojo estaría causado por la envidia: "una rana, viendo pacer un buey en el prado, pensó entre sí que podía ser tan grande si aquella su piel y cuero arrugado pudiese hinchar" (II.54).

Pero más importante es el cambio de significado pues mientras el Esopete advierte del peligro de autodestrucción que corre el pequeño al querer igualarse con el grande, el Baldo advierte contra los hombres de bajo estado que cometen robos, homicidios, conjuraciones, etc. por codicia, pues el pequeño urde conjuraciones contra el poderoso para acabar con él. El humilde es culpabilizado desde el principio por su intención casi innata de hacer daño.

la sedienta ambición ...es un deseo tan grave de honras que a los hombres hincha; a cada uno da diversas imaginaciones: a unos que han de ser grandes príncipes, que han de haber grandes 
dignidades, grandes honras. A los cuales quiera Dios no acontezca lo que a la rana que cuenta el poeta Horacio: la cual, como hubiese preguntado a un hijuelo suyo, que venía huyendo del buey que con los pies había trillado a sus hermanos, si podría ser ella tan grande como aquella bestia. - No, -respondió él- aunque revientes.

De adonde viene que un hombrecillo de zevil y muy bajo estado, de vil linaje y de peores condiciones, levante conjuraciones, acometa homicidios, haga latrocinios, trabe cuestiones sino por la ambición. (I, 21. 54)

Otra fábula que se usa para apoyar una tesis es la de la raposa y las peras, que encontramos abriendo el Libro IV del Esopete, la fábula I: "la primera fábula de la raposa y de las uvas"(IV.75).

En el Baldo hay algún cambio superficial, pues las uvas se sustituyen por peras que la raposa pretende hacer caer dando golpes con la cola. No hay que dirimir cuál es la versión original pues ya Jones recuerda "We must remember that a folktale is the sum of its versions; the versions are not partial reflections or evolved examples of an original, ideal text" Burrus y Goldberg (2002: xvii). ${ }^{20}$

El repertorio proverbial del Esopete facilitado por Lacarra (2009:310) indica sobre esta fábula: "Prudencia es disimular que no se procura la cosa cuando no se puede alcanzar", coincidiendo con el uso que se da en el Baldo. El capítulo XVIII, sin atacar la filosofía, acusa a los que después de haber desperdiciado su vida en argumentos filosóficos inútiles sin aplicación práctica que beneficie a la república fingen no interesarse por otros temas que en realidad desearían aprender.

"De adonde viene que los que en esto han gastado toda su vida y se vuelven a aprender las
otras cosas, pero, como no las pueden aprender porque están ya duros, menosprécianlas. Como
le aconteció en aquel tiempo que Hisopo dio palabras a los animales a la zorra, la cual como
hambrienta viese un gran peral, lleno de mucha fruta, comienza a dar con su cola al pie del
árbol pensando poder hacer caer algún fruto, pero como nunca pudo ni que cayesen las peras
que quería, se va diciendo que no aborrecía a más manjar que a las peras. Con estas fábula se
reprenden los que arriba dijimos que sobre cosas de poco seso se matan y gastan lo mejor de su
edad". (I, 18. 61-62)

La última fábula que se usa con intención argumentativa es la del ruiseñor, el cuclillo y el asno. No se podría asegurar si se trata de la fábula IV del Libro IV del Esopete "de Juno y del pavón y del ruiseñor" pues solo comparte algunos elementos comunes: el canto del ruiseñor causa envidia a otros. En el Baldo el envidioso es el cuclillo, en el Esopete el pavo real; en ambas obras aparece la figura de un juez: en Baldo es un asno, en el Esopete, Juno; en el Esopete Juno dictamina que cada animal tiene su don propio, su talento mientras que en el Baldo el ruiseñor pierde frente al cuclillo concluyendo así que los torpes no aprecian la verdad o que no todo juez sabe juzgar o que no hay que fiarse de las apariencias pues las orejas grandes no implican necesariamente saber oír. La "moralidad" del capítulo es una reivindicación de la verdad. Se menciona esta fábula para ejemplificar cómo la verdad es menospreciada de los hombres porque no pueden entender su belleza.

\footnotetext{
${ }^{20}$ Burrus y Goldberg, pg. 182, (en Jones, Steven Swann “The structure of Snow White. In Fairy Tales and Society: Illusion, Allusion, and Paradigm. Ed. Ruth B. Bottigheimer.Philadelphia: University of Pennsylvania Press, 1986, 165-86)
} 


\begin{abstract}
Anda la verdad en este tiempo buscando hombres que la acojan, menospreciada de los malos como el ruiseñor, el cual una vez contendió a cantar con el cuclillo y escogieron al asno por juez porque tenía más luengas orejas y así pensaron que oiría mejor. Habiendo cantado el harpado ruiseñor y el ronco cuclillo delante de él, él dio la victoria al cuclillo condenando al dulce canto del ruiseñor porque no lo entendía. De adonde esta ave enojada apeló a los hombres, y, siempre cuando ve a alguno, se para a cantar más suavemente que cuando está solo para que juzgue por él. Pero el hombre entendiendo lo que es su intención, no pasa sin darle victoria. (I, 7. 31)
\end{abstract}

\title{
5.3 Uso como modelo de conducta
}

Como señalé al comienzo, otro de los usos de la fábula es el servir de modelo de conducta y en el prólogo al Baldo se ofrecen dos ejemplos que se aplican para el regimiento de reinos.

El autor del Baldo hace referencia a la fábula IX del Libro IV del Esopete "del caballo y del ciervo y del cazador" para aludir a un hecho histórico en el que el uso de una fábula evitó que un pueblo fuera sometido. Esta fábula mantiene el mismo significado que en el repertorio proverbial del Esopete: "No ponga el hombre enemistad con quien le pese después de haberla tomado."

el poeta Stesichoro apartó a los ciudadanos de Hímera con la fábula del caballo que, por vengarse del ciervo, se dejó enfrenar y, después de vencido, se quedó en poder del hombre a que, para vengarse, no tomasen al tirano Falaris, rey de los agrigentinos, porque aunque venciesen a sus enemigos, quedarían en sujeción perpetua. (7)

La segunda fábula esópica mencionada pero que no figura en el Esopete es la de la raposa y las moscas. ${ }^{21}$

Asimismo el fabulador Isopo aportó a los de Samo con la fábula de la raposa mordida de las moscas que no mudasen jueces. Por esta causa Tiberio César daba los magistrados de luengo tiempo, porque no perdona a los pueblos el reino breve. (7)

En La vida de Esopo el protagonista alecciona a los habitantes de Samo no con esta fábula sino con la de los lobos, las ovejas y los perros. Esto quizás indique que el autor del Baldo manejaba una versión distinta de La vida de Esopo.

Tenemos otra fábula, la más extensa del Baldo, que no aparece recogida en el Esopete sino en Noctes atticae de Aulo Gelio y que sin embargo este autor la atribuye a Esopo. Gernert sugiere como título para ella "la cogujada y la mies" 22. Esta fábula ocupa todo el capítulo XXIX del libro II de Las noches áticas: "A pologus Aesopi Phrygis memoratu non inutilis" Apólogo útil de Esopo el Frigio. Se presenta la fábula tras dedicar a Esopo un reconocimiento:

enseñó no con la imperiosa severidad de un filósofo que dogmatiza, sino disimulando sus lecciones bajo fábulas picantes y amables que hacen entrar las más útiles reflexiones en la mente conquistada por la atracción de lo ameno (vol.I, 173).

\footnotetext{
${ }^{21}$ El fabulador francés La Fontaine introduce en el Libro XII de sus Fábulas una semejante que lleva el número 13: El zorro, la mosca y el erizo (1940: 240).

${ }^{22}$ Baldo, pág. Xiii.
} 
Nuestro autor siguió en el Baldo el mismo espíritu que movía a Aulio Gelio en su obra: compilar enseñanzas interesantes para que el público de su libro tuviera una honesta erudición. Si analizamos el texto original vemos que el autor del Baldo hace casi una traducción literal del mismo aunque suprime algún comentario: el hecho de que los polluelos estas aves cuando llega la siega ya tienen plumas; y añade algún otro: se dice que la cogujada es "vieja y experimentada".

Falqueto, haciendo de narrador metadiegético, es quien nos cuenta esta fábula que oyó de boca de un pastor anciano y que empieza con un proverbio: "no confíes en otros sino en ti" (I, 7. 28-29). El pastor, que con su hijo espera infructuosamente ayuda de parte de vecinos y familiares para esquilar el rebaño, recuerda por la similitud del escenario la fábula de la cogujada, en la que se cambia el esquilar ovejas por recoger el trigo. Seguidamente el padre recalca al hijo también la lección: “Esto nos amonesta, hijo, que no confiemos como livianos en el socorro de nuestros amigos o parientes" (I, 7. 29). Por la excesiva extensión de la misma y las limitaciones de espacio no se reproduce.

\subsection{Uso como comparación.}

Es lugar común decir que el reino animal nos ofrece comportamientos que pueden compararse con los de los hombres, y de hecho las fábulas utilizan esto como rasgo distintivo de género. Así, La vida de Esopo comienza explicando su origen: "fueron falladas porque por las palabras fingidas delas animalias irracionales de unas a otras la imagen \& costumbres de los ombres fuesen conoscidas" ${ }^{23}$.

En el propio Baldo se dice que las transformaciones o metamorfosis en piedras, árboles, aves o animales que sufren quienes se pasean por el infierno responden a las características de las personas.

Circe, convertidora de hombres en brutos animales, enseña los hombres solamente en la forma y humana voz ser presto convertidos en los torpes deseos a que su voluntad y inclinación atrae no les contradiciendo semejándose cada uno a la forma que ama: como los libidinosos en osos, los soñolientes en puercos, los tragones en lobos, los feroces sin saber en leones y así los otros. (6)

La primera aparición de una fábula que compara el comportamiento de unos hombres al comportamiento que se refleja en una fábula la tenemos en el capítulo XVII. Siguiendo el estilo heterodoxo propio del Baldo, en el capítulo XVII el hecho de llegar a una playa con piedras que brillan y descubrir entre ellas la piedra filosofal da lugar para relatar a Cíngar la historia del vidrio. El capítulo parece transformarse en un ensayo sobre la alquimia que se prolonga hasta el capítulo siguiente y que tiene por protagonistas no ya a los caballeros sino a los filósofos y nigrománticos de Corintio a quienes los ciudadanos movidos por la avaricia requerían para que les enseñaran el arte de la alquimia llegando a vender sus posesiones para conseguirlo. Es entonces cuando el autor, a modo de comparación y no como argumentación en favor de ninguna idea, menciona la fábula del "perro y el trozo de carne" con el mismo significado que en la

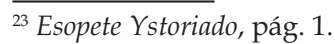


fábula V del Libro I del Esopete: "no debe el hombre, codiciando lo ajeno y dudoso, dejar lo suyo que es cierto, aunque lo que codicia le parezca más" (I.34).

Todos los más vendían sus haciendas, dándoselas a los filósofos porque las multiplicasen, pensando quedar muy ricos. No parecía sino al perro que dejaba el bocado que tenía por la mayor sombra que en el agua veía y perdiólo todo. (I, 18.59)

Tenemos otro momento en que el autor del Baldo menciona una fábula para hablar del comportamiento de dos caballeros, la del león y la mosca.

No mirando esto Beliarte de él, dándole recios golpes como la pequeña mosca que al grande león pica, confiándose en el vuelo y el león se va poco a poco ensañando, así Baldo se iba airando y, por derribarlo, le dio un pequeño golpe en los pechos, mas, dando la punta de la espada en cosa blanda, que era un jubón, se entró por los pechos atravesándole el corazón. (II, 32. 232)

Podemos rastrear en el Libro II del Ysopete la fábula XII con un significado similar, si bien con otros personajes, el calvo y la mosca (II. 52). La intención didáctica coincidiría pues nos enseña que no debemos hacer mal a otros que sin ningún trabajo pudieran causarnos desgracia, el calvo aunque se haga daño con sus propios manotazos mata la mosca. Esta mención a la fábula nos vuelve a indicar que nuestro autor tal vez no manejara la misma edición del Ysopete, o que introducía variantes conocidas en la época.

\section{CONCLUSIÓN}

El Baldo es un libro de caballerías poco ortodoxo en cuanto al rigor temático propio de estas obras pues da cabida a un amplio repertorio textual. La avalancha de material erudito se distribuye de forma muy desigual en una trabazón vertiginosa de referencias a fabulas, citas clásicas y doctrina religiosa, donde lo culto y lo popular se encuentran.

En este modo de narrar distinto, las fábulas, elemento propio de la literatura popular, se colocan al lado de menciones a Aristóteles, Platón, Ovidio, Sócrates, etc. adquiriendo así la misma categoría y se usan a discreción cuando el autor necesita apoyar sus ideas, proponer semejanzas entre el comportamiento humano y animal, o dar consejos. Estas enseñanzas fabuladas no podían dejarse de lado en una época en que la literatura didáctica está en pleno auge. El autor recoge la tradición clásica de las fábulas aunque adaptándolas a sus intenciones narrativas incorporando nuevas interpretaciones y usando versiones distintas de las más conocidas.

El autor del Baldo sin duda acallaría cualquier comentario que atacara su obra por carencia de utilidad pues de manera efectiva cumple lo que promete en su prólogo "que tome algún provecho el lector"(10). El autor confecciona un texto complejo y denso lleno de enseñanzas propias de una obra de misceláneas, un compendio del saber del momento que sirve de base para proponer modelos de conducta útiles para vivir en sociedad, y en el que las fábulas esópicas encuentran un espacio al lado de las obras clásicas ya consagradas. 


\section{BIBLIOGRAFÍA}

Bizarri, H. (2011): “El Esopete ystoriado y las teorías sobre la fábula", Acta Poética, 322:55-73

Burrus, V. y Goldberg, H. (eds.) (1990): Esopete Ystoriado (Toulouse, 1488), Madison, Hispanic Seminary of Medieval Studies.

Cattan, F. “Adaptaciones ciceronianas en Noctes Atticae de Aulo Gelio", en V Jornadas de estudios clásicos y medievales "diálogos culturales". Universidad Nacional de la Plata, Argentina.

Gelio, A. (2006), Noctes Atticae, Marcos Casquero, M.A. y Domínguez García, A. (eds.), 2 vol. , León, Universidad de León.

Gernert, F. (2004): “La recepción de la mitología en los libros de caballerías: El Baldo (1542)", en Friedlein, R. y Neumeister, S. (eds.) (2004): La mitología antiga a les literatures catalana $i$ castellana entre l'Edat Mitjanai la Moderna, Barcelona, Publicacions de 1'Abadia de Montserrat, 85-93.

Gernert, F. (ed.) (2002), Baldo (Sevilla, 1542), Alcalá de Henares, Centro de Estudios Cervantinos.

Gernert, F, (2000): Baldo. Guía de lectura, Alcalá de Henares, Centro de Estudios Cervantinos.

Lacarra, M.J., (2009) "Fábulas y proverbios en el Esopo Anotado", Revista de poética medieval, 23: 297-329.

La Fontaine (1940), Fabulas, Barcelona, Montaner y Simon.

Martín Romero, J. J. "Buenas doctrinas y enxemplos". Aspectos sapienciales y didácticos en los libros de caballerías, Memorabilia 8 (2004-2005) [parnaseo.uv.es/ memorabilia/memorabilia8/martin/index.htm] (consultado en octubre de 2012) 



\title{
TRADICIÓN Y MODERNIDAD: LA FÁBULA LA RAPOZA SE VA AL HADJILIK EN EL PERIÓDICO SEFARDÍ EL KONSEJERO (SALÓNICA, 1913)
}

MARÍA SÁNCHEZ-PÉREZ

Universidad de Salamanca ${ }^{1}$

\section{Resumen}

El periódico sefardí El Konsejero fue publicado en Salónica en 1913. Estaba dirigido por David Baruj Bezés, un editor y traductor muy conocido en Salónica, además de uno de los impresores más importantes de la ciudad a comienzos del siglo xx. Solamente hemos conservado un número de El Konsejero, concretamente el primero.

El objetivo de este artículo es dar a conocer la fábula "La raposa se va al hadjilick", publicada en este periódico sefardí e intentar rastrear sus posibles fuentes.

Palabras clave: El Konsejero, David Baruj Bezés, prensa, sefardíes, judeoespañol, fábula, “La raposa se va al hadjilick".

\begin{abstract}
The Sephardic newspaper El Konsejero was published in Thessaloniki in 1913. It was run by David Baruj Bezés, an editor and translator well know in Thessaloniki, also one of the most important printer in this city in the early twentieth century. Only we have retained a number of El Konsejero, specifically the first. The aim of this paper is to present the fable "La raposa se va al hadjilick" published in this Sephardic newspaper and attempting to establish their possible sources.
\end{abstract}

Key words: El Konsejero, David Baruj Bezés, press, Sephardic, Judeo-Spanish, fable, "La raposa se va al hadjilick".

\section{INTRODUCCIÓN: LOS JUDÍOS SEFARDÍES EN LA DIÁSPORA}

Losjudíos españoles que fueron expulsados delas coronas de Castilla y Aragón en 1492 se asentaron, en su diáspora, por diferentes lugares del mundo, fundamentalmente en la zona de Marruecos y de los Balcanes. Esa cultura sefardí diaspórica ha tenido como rasgos específicos de su identidad el judaísmo y sus orígenes hispánicos. Y como lengua de comunicación y de expresión literaria una variedad lingüística románica derivada del español medieval: el judeoespañol, sefardí o ladino.

\footnotetext{
${ }^{1}$ Correo-e: mariasanchezperez@usal.es. Recibido: 20-12-2012. Aceptado: 15-03-2013.
} 
Sin duda, uno de los lugares donde los sefardíes encontraron mejor acogida fue en el Imperio otomano. El sultán Bayaceto II, consciente de que los judíos constituían un importantísimo potencial económico y humano, les dio toda clase de facilidades para asentarse en sus territorios. Durante los siglos XVI y XVII la preponderancia de los sefardíes en el mundo judío oriental influyó decisivamente en la vida política, cultural y económica del Imperio otomano, de hecho fueron los sefardíes quienes introdujeron la imprenta en el Imperio y quienes la tuvieron como monopolio hasta 1727 -fecha en la que se levantó a los turcos la prohibición de imprimir en su lengua-. Por otra parte, el siglo XVIII es considerado como el Siglo de Oro de las letras sefardíes, ya que el mundo sefardí de Oriente conoció un singular florecimiento de la literatura en judeoespañol. Posteriormente, a mediados del siglo XIX comenzaron a soplar nuevos vientos en el tradicional mundo sefardí: entraba el influjo de Occidente. Surgieron entonces los llamados géneros adoptados, sin tradición en la literatura judía precedente y que empezaron a cultivarse con un claro afán de emulación por las literaturas occidentales: se escribieron novelas y poesía de autor a la manera europea; surgieron aquí y allá grupos de teatro aficionados que producían textos teatrales para su propio consumo y adaptaban o traducían las obras de otras literaturas; y proliferaron las publicaciones periódicas. Así pues, la difusión de la prensa fue un factor decisivo en el desarrollo de las comunidades sefardíes de Oriente. Y se creó una activa industria editorial en diferentes ciudades, dentro y fuera del Imperio otomano, como Salónica, Esmirna, Constantinopla, Viena, Sofía, Jerusalén, El Cairo, diversas ciudades de Estados Unidos, etc. ${ }^{2}$.

\section{SALÓNICA Y EL PERIÓDICO EL KONSEJERO}

Una de las principales comunidades sefardíes de Oriente -desde finales del siglo xv hasta el Holocausto nazi- fue la de Salónica. Se trata de la ciudad del imperio otomano donde habitó la mayor comunidad judía, principalmente sefardí, desde su llegada a finales del siglo xv hasta la Segunda Guerra Mundial. Mark Mazower señalaba:

Salónica -la "ciudad codiciada" [...]- era un prototípico puerto políglota del Imperio otomano cuyos limpiabotas se hacían entender en media docena de lenguas, pero poseía un rasgo singular: del calidoscopio étnico que formaba su población, el grupo más numeroso no eran los griegos, los turcos, los albaneses ni los eslavos, sino los judíos sefardíes (Mazower 2001: 151 y $164)^{3}$.

\footnotetext{
${ }^{2}$ Como estudio de conjunto sobre los sefardíes, véase Díaz-Mas (2006). Para la historia de los sefardíes son útiles los artículos de la colectánea editada por Méchoulan (1992). En el caso de la historia de los sefardíes orientales es ya clásico el estudio de Franco (1897). Para el proceso de occidentalización y modernización de las comunidades sefardíes: Benbassa y Rodrigue (2004); y los artículos incluidos en DíazMas y Sánchez Pérez (2010). Para la creación literaria sefardí, véase Romero (1992), y especialmente para los géneros adoptados, págs. 177-310. Sobre el papel del periodismo como elemento de modernización de los sefardíes del imperio otomano, véase el libro de Abrevaya Stein (2004). Una síntesis útil sobre la lengua sefardí es la de Lleal (1992).

${ }^{3}$ Véanse también Nehama (1935-1978); Benbassa y Rodrigue (2004); y Mazower (2009).
} 
Los sefardíes estaban presentes en todas las escalas sociales, desde las más humildes hasta las más privilegiadas. Salónica se convirtió así en uno de los centros más importantes de la vida cultural y religiosa sefardí y, desde el siglo xvI, fue la comunidad judía más importante del Mediterráneo oriental, hasta el punto de ser conocida como "la Jerusalén de los Balcanes".

El máximo esplendor de la comunidad sefardí de Salónica se produjo a partir de mediados del siglo XIX, cuando la ciudad vivió un auténtico renacimiento gracias a su industrialización, convirtiéndose en un centro económico neurálgico dentro del Imperio otomano. A la renovación que vivió la propia ciudad hay que unir desde finales del siglo XVIII la influencia decisiva de la Haskalá, que quiere decir 'ilustración', y que fue implantándose paulatinamente en las comunidades sefardíes gracias al impulso del judaísmo ruso y centroeuropeo. A ello hay que añadir de manera decisiva la implantación de la red de escuelas que realizó la Alliance Israélite Universelle desde 1860 en diferentes ciudades del mundo (Rodrigue 1990): “Por medio de ellas se canaliza hacia el sefardí la producción literaria y los valores culturales europeos. El sefardí se abre, pues, a occidente" (Romero 1992: 178). Gracias a la labor de esta organización filantrópica de origen francés, cuyo objetivo era ayudar a la regeneración material y moral de sus correligionarios, los aires de la modernización, el laicismo y la occidentalización calaron muy pronto en las comunidades sefardíes, al menos en algunos sectores. La literatura tradicional y patrimonial judía continuará, pero se añade ya la influencia del mundo cultural de occidente de carácter no judío, de ahí el surgimiento de los llamados géneros adoptados -como citamos al principio- entre los que se incluye el periódico que ahora analizamos y el hecho de que en él se haya llegado a publicar, entre otros cuentos y facecias, una fábula.

Pensemos que conservamos más de 300 periódicos sefardíes desde mediados del siglo xIx hasta la Segunda Guerra Mundial (es fundamental el catálogo de Gaon 1965). Buena parte de esta prensa periódica sefardí se publicó en judeoespañol aljamiado, aunque existe también algún periódico en caracteres latinos y hay publicaciones en otras lenguas -en hebreo o francés, por ejemplo- y, por lo tanto, utilizan distintas grafías y alfabetos. Los contenidos que encontramos en estos periódicos son de muy diversa índole: obras de información general, publicaciones de tendencias políticas distintas -sionistas, socialistas-, pero también existen periódicos satíricos, humorísticos, literarios, científicos, etc. (véanse Hassán 1966; Romero 1992: 177-219; Abrevaya Stein 2004). Todos estos periódicos tuvieron una diferente duración y carácter: hubo periódicos muy longevos, que se publicaron ininterrumpidamente durante décadas -como El Tiempo, de Estambul; La Buena Esperanza, de Esmirna; o La Époka, de Salónica-, pero muchos otros fueron intentos fallidos o publicaciones efímeras, de las que aparecieron solo unos pocos números. El Konsejero, que es la publicación que ahora nos ocupa, fue uno de esos periódicos efímeros, del que únicamente se ha conservado un ejemplar de $1913^{4}$.

\footnotetext{
${ }^{4}$ Este trabajo se inscribe dentro del proyecto de investigación "Los sefardíes ante sí mismos y sus relaciones con España. III" (FFI2012-31625) del Ministerio de Economía y Competitividad. Manejamos reproducción del ejemplar que se encuentra en el Instituto Ben-Zvi de Jerusalén.
} 


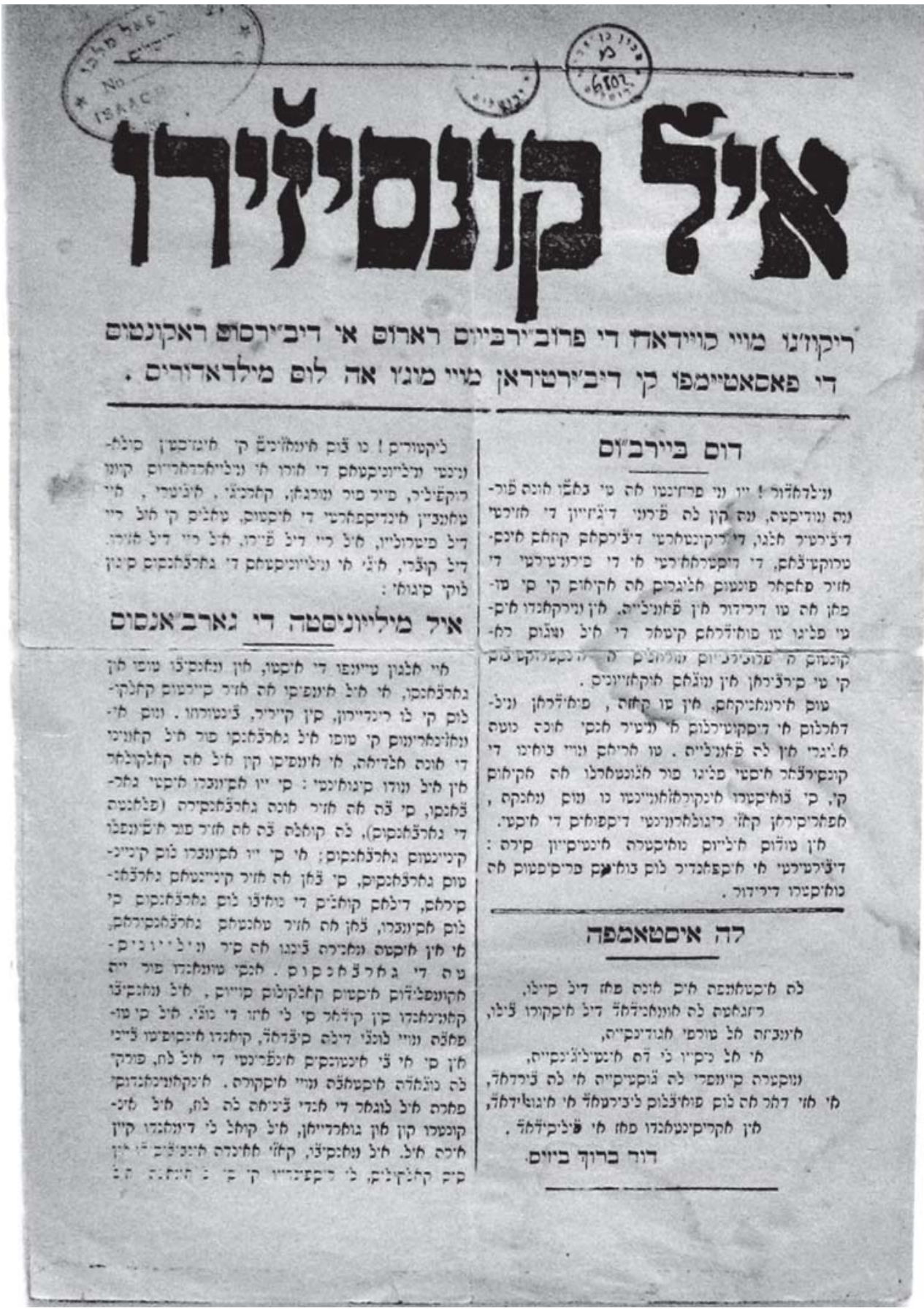

Portada del primer y único número conservado del periódico El Konsejero. 


\section{CARACTERÍSTICAS DEL PERIÓDICO EL KONSEJERO}

El Konsejero (Gaon 1965: 110, núm. 253) se publicó, como la mayoría de los periódicos sefardíes, en judeoespañol aljamiado, es decir, escrito en caracteres hebreos. Del periódico El Konsejero solamente hemos conservado las cuatro páginas del primer número en las que se indica que el periódico era realizado por el impresor y editor David Baruj Bezés, ya que es él mismo quien firma al principio de la publicación la declaración de intenciones de ésta y, precisamente, salió de la misma imprenta que él poseía en Salónica, como señala al final del periódico: “Estamparía David Baruj Bezés, kuartier Rogos" ${ }^{\prime}$. Sabemos que David Baruj Bezés fue un editor, redactor y traductor muy conocido en Salónica, además de uno de los impresores más importantes de la ciudad a comienzos del siglo xx. De las prensas de su imprenta salieron obras editadas y redactadas por él mismo, como por ejemplo uno de los libros de miscelánea propios de las festividades, El buqueto de Pésah (Salónica, s.a.), que incluía los relatos de "El amor de Rosa", "¿Cale muerirmos?", "El detective criminal" y "El aniversario". Tradujo del inglés las siguientes obras: El testamento y Humberto y Adelina, que se publicó en la Biblioteca de la hermosa Eloisa en 19086. David Baruj Bezés fue también editor de mahzorim de Yom Kipur $(1908,1914,1931)$ que, como otros de Salónica, incluían los textos de Yehí rasón y Séder 'abodá. Fue editor del periódico que ahora nos ocupa, El Konsejero y, posteriormente, también lo fue del periódico festivo El Burlón (1920) (Romero 1992: 54, 186, 208, 229, 251).

Refiriéndonos ahora a las características del periódico, la cabecera de $E l$ Konsejero era muy sencilla: ocupando un solo renglón, aparecía el título del periódico en letras merubá7. Debajo, en una especie de subtítulo, se integraban dos renglones más en el mismo tipo de grafía con la siguiente indicacións: "Rekojgo muy kuidado de probervios raros i diversos rakontos de pasatiempo ke divertirán muy mucho a los meldadores". Con estos datos, al menos, sabemos cuál era la primera intención de David Baruj Bezés: presentar una serie de proverbios y refranes, junto con la inclusión de cuentos y facecias entre sus páginas. De ellas se deduce que el precepto horaciano de delectare et prodesse estaba muy presente en la mente de este editor sefardí a la hora de componer su publicación.

Entre las páginas de este periódico se halla precisamente la fábula de la que nos ocuparemos a continuación.

\footnotetext{
${ }^{5}$ Incluimos al final un glosario aclarando aquellos términos que, en nuestra opinión, pueden ofrecer alguna dificultad de comprensión al lector hispano culto.

${ }^{6}$ La labor de traducción la realizó en colaboración con su hijo Benedet Bezés.

${ }^{7}$ Merubá: letra cuadrada. Rashí: semi cursiva.

${ }^{8}$ En los textos sefardíes utilizamos las siguientes equivalencias gráfico-fonéticas: $b$ bilabial oclusiva sonora $/ \mathrm{b} / ; v$ bilabial fricativa sonora $/ \mathrm{b} / ; d j$ prepalatal africada sonora $/ \hat{y} / ; h$ uvular fricativa sorda $/ \Upsilon / ; j$ prepalatal fricativa sonora $/ \check{z} / ;$ ly lateral palatal $/ \lambda /$, que la mayor parte de las veces se realiza en judeoespañol como /y/; ny nasal palatal / $\mathrm{y} / ;$ s alveolar fricativa sorda /s/; $z$ alveolar fricativa sonora /z/; sh prepalatal fricativa sorda / $\breve{s} / ; t s$ alveolar africada sorda / $\hat{\mathrm{s}} /$. Puntuamos, acentuamos y versalizamos los textos que citamos.
} 


\section{FÁBULA: "LA RAPOZA SE VA AL HADJILIK"}

La fábula La rapoza se va al hadjilik, es decir, La zorra se va de peregrinación ocupa el sexto lugar dentro de las secciones del periódico, ya que los contenidos del periódico El Konsejero son los siguientes:

1. [p. 1, col. a] [Cabecera] «El Konsejero. Rekojgo muy kuidado de probervios raros i diversos rakontos de pasatiempo ke divertirán muy mucho a los meldadores»

2. [p. 1, col. a] «Dos vierbos» [En este apartado se incluye la declaración de intenciones de la publicación].

3. [p. 1, col. a] «La estampa» [Elogio de la imprenta]

4. [p. 1, col. b] «El milyonista de garvansos»

5. [p. 2, col. b] «Refranes i frazes kastelyanas»

6. [p. 3, col. a] «La rapoza se va al hadjilik»

7. [p. 3, col. b] «Refranes»

8. [p. 4, col. a] «El administrador i el taviernero»

9. [p. 4, col. a] «El lechero y la mula»

10. [p. 4, col. b] «Refranes»

11. [p. 4, col. b] [Colofón] «Estamparía David Baruj Bezés, kuartier Rogos»

Así pues, entre diferentes cuentos, anécdotas y refranes se halla nuestra fábula, cuyo texto en el periódico es el siguiente:

Una vez izo tanta luvia a muchedumbre i mientres tantos días kantidad ke una sierta rapoza se iva a muerir de la ambre, ma en su ventura kedó la luvia i salió el sol. Entonses salió elya sin ipokrezía, tuviendo en su garganta enkolgado un trespil i kaminando avagar sin mirar más ke adelantre de sí. Al verla ansí un galyo les dijo a sus gaínas: «Veo la senyora rapoza muy pensativle i muy abatida, venid le avlaremos».

-Seas bienvenida, senyora rapoza -le dizo el galyo.

-Kedadvos en buena ora -le dizo la senyora rapoza kon mucho abatimiento.

- ¿Ánde vas tanto pensativle?

-Al hadjilik.

-Vamos i nozotros.

-Venid, ma atinad, porke a mí no me plaze ke me agásh pekar más, puede me arepente por los males ke tuve echo i vo para salvar a mi alma.

Ivan adelante las galynas kon su gayo i de detrás la senyora rapoza i kontinúan kaminando un poko más. Enfrente binieron a enkontrarsen kon tres babás i sus maridos, las kuales apenas vieron a la rapoza ke kamina tanto abatida kon las galynas. Yamaron a akeas i tomaron la lisensia de akompanyarlas.

Kaminaron más adelantre i las vieron algunas indianas, ke vieron i elyas también endjunto i kaminó la rapoza asta ke se izo de noche. Entonses dijo a los ke estavan kon elya: «E, kedadvos un poko, ya savésh ke mos estamos yendo para el hadjilik i kale ke esta noche mos kedemos akí en esta kaverna. Vozotros vos vash más para ai a la fondura i yo me vo a arimar akí delantre para ke no entre alguna otra rapoza i vos koma i será kavsa ke terné pekado por elyo agora a la vejes». 
I ansí fue echo, ma a la manyana la senyora rapoza azí komo si se estuviera sonyando i ke de las vozes del galyo i de las galynas se despertó aturvada i yamó delantre de elya primero al galyo: «-Bre, ermano -le dize-. Todos los ombres toman una mejor, tú, empero, salites de tus términos i aun kon todo no pensash, ¿kómo mos vamos para el hadjilik?».

Esto diziendo, sin esperar ninguna repuesta, echa la mano, keridos míos, afera al galyo i se lo kome. Después yama a las gaínas: «Ya venid akí, vozotras, senyoras, vozotras danyatesh al mundo i poko manka ke por vuestra kavza las yore. Yo i todas las mujeres paren chika kriatura i no se los siente ni el portal de la puerta i vozotras kon un güeveziko ke parísh me danyastesh kon vuestros gritos i me ensodresésh los oídos».

I komo fue por el gayo, las dezgrasiadas de las gaínas también tuvieron la mizma suerte. Después yama a las babás: -Venid, vos preguntaré. ¿Vuestros padres shastres eran?

- No, respondieron las babás.

- Yo, entonses, kon ladrones no me vo al hadjilik, porke ¿ande las topatesh tantas kolores? Vedre, kolorado, rubio. Dio un salto, las aferó i se las komió. I a elyas es inútile de dezir ke las indianas también no tuvieron mejor suerte. I fue kuando ya akavó en la kaverna su orasión ke arebivió i, komo pekadora, se repintió i no fue al hadjilik si no ke kuando la enseró otra vez la luvia.

Esto esplika ke kale alesharmos de los ombres ipókritas, másimamente de akeos ke lya konosimos el komporto ke tienen.

A través de la lectura de esta fábula vemos cómo se presenta a una zorra arrepentida, que cuando se ve en peligro de muerte se propone ir de peregrinación para expiar sus culpas. Durante su camino se topa con diferentes aves -gallinas, ocas, pavos- que, al verla tan abatida y cabizbaja, deciden acompañarla en su peregrinación. Al llegar la noche la zorra sigue comportándose de un modo afable al indicar a las aves que se resguarden en una cueva, mientras ella se quedará en la puerta para protegerlas. Sin embargo, a la mañana siguiente, entre el canto del gallo -que la despierta sobresaltada- y el alboroto de las gallinas al poner los huevos, junto con el abanico de colores desplegado por los pavos, hace que la zorra saque a relucir su verdadera naturaleza depredadora, se enfurezca y decida comerse a todos ellos, sin mostrar, finalmente, ningún tipo de arrepentimiento. La moraleja, por su parte, queda clara: "Es conveniente que nos alejemos de las personas hipócritas, especialmente cuando ya conocíamos sus comportamientos de antemano".

La fábula que aquí presentamos toma la idea de la zorra como animal astuto, cruel y poco de fiar, conceptos que ya estaban en las fábulas de Esopo y en la tradición folklórica posterior. Sabemos que existen evidentes paralelos entre la tradición esópica y algunos textos del Talmud y del Midrás (Mirallés Maciá 2009) y, desde luego, existen semejanzas entre el texto que aquí presentamos con otros exemplum o fábulas, como De lo que aconteçió a un raposo con un gallo recogido en El Conde Lucanor, o en fábulas muy conocidas como El águila y la zorra, La zorra y las uvas, La zorra y la liebre, etc., donde la

\footnotetext{
9 “Talmud (hebreo 'enseñanza'), comentario rabínico a la Torá, que está compuesto a su vez por dos partes (la Mishná y la Guemará) y se divide en varios órdenes o tratados. Midrásh (heb. 'interpretación') comentario de los libros bíblicos que extrae de ellos lecciones, principios morales y conceptos teológicos, integrando abundantes materiales hagiográficos y legendarios". Ambas definiciones están tomadas de Díaz-Mas y De la Puente (2007: 171-193), s.v. talmud, s.v. midrásh.
} 
raposa suele aparecer caracterizada casi siempre por su astucia, pero también por su mal obrar o, en este caso, por su hipocresía.

Ahora bien, ¿de dónde tomó David Baruj Bezés esta fábula para incluirla en su periódico? Sabemos que, en algunas ocasiones, las fuentes de los editores de estas publicaciones sefardíes eran otros periódicos -locales, nacionales o extranjeros-, así como también libros, manuales, traducciones, etc., pero son muy pocos los que consignan el lugar del que sacaban los contenidos para sus periódicos, frente a unos pocos que sí preferían hacerlo en una expresión de intentar dar mayor prestigio a su publicación.

Entre los sefardíes, el cuento popular ha tenido desde siempre un lugar destacado. Ya los primeros romanistas que estudiaron el judeoespañol recogieron cuentos en sus encuestas de campo (entre otros: Wagner 1914, 1930; Luria 1930; Crews $1935,1979)^{10} \mathrm{y}$, hasta época reciente, los cuentos y relatos se han mantenido vivos en la tradición sefardí, como lo demuestran las antologías de Koen Sarano (1986, 1991, 1995, $2000)^{11}$. Es cierto que en la tradición sefardí existen diferentes consejas y cuentos cortos -de carácter maravilloso, cómicos, etc.-, pero es llamativo e importante destacar que apenas se han documentado fábulas de animales.

Al rastrear las posibles fuentes de esta fábula hemos comprobado que no se encuentra documentada de forma exacta en la tradición hispánica (Chevalier 1983; Camarena y Chevalier 1997 y 2003; Espinosa 1946 y 2009) ni en la sefardí (Larrea Palacín 1952-1953; Haboucha 1992) ${ }^{12}$. Dada la práctica inexistencia de fábulas de animales en la tradición oral sefardí, parece muy probable que no provenga de ahí, sino que se trate de una traducción o adaptación de otra lengua -como veremos a continuación-.

En otra ocasión hemos encontrado entre las páginas de estos periódicos cuentos y facecias que tienen una clara raigambre medieval. En algunos casos, provienen de la cultura oriental y se tradujeron en Castilla en la Edad Media, pero en ocasiones, es difícil saber si los sefardíes conocían esos cuentecillos a través de la literatura medieval hispánica -y, por lo tanto, pertenecían a su bagaje cultural antes de su expulsión- o si esa tradición les llegaba directamente del mundo musulmán y, de este modo, a su convivencia durante siglos en diferentes países islámicos (véase Sánchez Pérez 2010).

Y esto es precisamente lo que nos encontramos en este caso: todo parece indicar que se trata de una fábula que debía estar en la tradición árabe, ya que hemos encontrado un cuento popular muy parecido a nuestra fábula en una novela del autor

\footnotetext{
${ }^{10}$ Sobre las encuestas de Subak y Luria, véanse Liebl (2009) y (2010).

${ }^{11}$ Véanse, además, los trabajos de Haboucha (1992); y Alexander (1989). Precisamente en Koen Sarano (1986: 225) se encuentra recogida una conseja con el título "La rapoza", pero nada tiene que ver con la fábula que ahora nos ocupa.

${ }^{12}$ En el Motif-Index de Thompson (Thompson 1955-1958) aparecen recogidos diferentes motivos folklóricos relacionados con el zorro que podrían tener alguna ligera semejanza con nuestra fábula, como por ejemplo: A2494.9.2 Enmity between fox and chickens; B151.1.3 Fox determines road to be taken; B253.3 Fox fasts as penance; K2027 Fox confesses to cock then eats him.
} 
griego Stratís Tsircas ${ }^{13}$. Tsircas escribió una trilogía titulada Ciudades a la deriva, en la que describe la acción del partido comunista entre la población griega de varias ciudades del Mediterráneo, en un momento en que Grecia está ocupada por los nazis y los griegos, en el exilio, intentan formar un gobierno para cuando Grecia sea liberada. Está compuesta por las novelas El Club -que se desarrolla en Jerusalén bajo el mandato británico-, Ariagni -cuya acción se desarrolla en El Cairo- y Bat -que transcurre en Alejandría-. Es precisamente en la segunda novela, Ariagni, donde encontramos esta fábula en boca de un mendigo ciego, Sháltam:

Había una vez un ratón que tenía mucha hambre. Mientras buscaba algo que comer aparece el gato. El ratón se esconde detrás de un tablón. Le dice el gato: Eh, ratón, ¿te vienes conmigo a espiar a las gallinas? Le dice el ratón: Mi padre me ha dicho que no me fíe de mi enemigo y que no tenga trato con él. Amigo, le dice el gato, yo he hecho la peregrinación, soy un hach, llevo un rosario grande y he dado mi palabra de no hacer daño jamás a un ratón. Me paso el día rezando. El ratón fue a su madre y se lo contó. Hijo mío, le dice, no vayas con tu enemigo; tu padre te lo ha prohibido. Pero, madre, este es un hach, lleva al cuello un rosario grande, para llevar cuenta de sus oraciones. Ah, bueno; entonces puedes ir con él. Sin pensárselo dos veces va a buscar al gato. De acuerdo, le dice, iré contigo. Al cabo de tres días el gato sintió hambre. Se zampó el ratón de un bocado. El cuento enseña: no te fíes de tu enemigo, no tengas trato con él (Tsircas 2011: 458-459).

Como vemos, tanto en la fábula sefardí como en este cuento se menciona el hadj -hajj, hach, hagg- o peregrinación musulmana a la Meca y el trespil, es decir, el rosario o sarta de cuentas que utilizan los musulmanes. En ambos casos nos hallamos ante animales que confían en sus enemigos - una zorra en un caso, un gato en el otro- y éstos, finalmente, terminan devorándolos. La moraleja, en los dos casos, es la misma.

Parece claro, por tanto, que se trata de un cuento o fábula de la tradición árabe y, en el caso del periódico sefardí es muy acorde con el entorno otomano en el que se publicó El Konsejero, en 1913, solamente un año después de que la ciudad se incorporase a Grecia, cuando todavía el ambiente y la sociedad eran profundamente otomanos y no se había producido aún el proceso de helenización que se llevaría a cabo en los años posteriores (Morcillo Rosillo 1997; Mazower 2001 y 2009).

Estudiando los contenidos de estos periódicos, parece evidente que la inclusión de estos elementos de la literatura oral -cuentos, facecias, fábulas, refranes- contribuía a preservar la tradición entre las comunidades sefardíes de Oriente y, con ella, sus rasgos identitarios. Pero, por otro lado, el hecho de que bastantes editores y directores sefardíes de estos periódicos se dedicaran a traducir y adaptar obras de otras literaturas y tradiciones -como ocurre en este caso- revela la importancia que tenía para ellos ayudar al desarrollo y a la regeneración moral de sus correligionarios.

La inclusión de este tipo de textos en una publicación como El Konsejero, de principios del siglo $\mathrm{xx}$, refleja aspectos significativos de la identidad y la mentalidad sefardíes. En este sentido, algunos de estos impresores y editores sefardíes lo que

\footnotetext{
${ }^{13}$ Stratís Tsircas es el seudónimo de Yanis Jatsiandreas (1911-1980), un autor comunista griego que participó en la II Guerra Mundial con las tropas griegas, que formaban parte del ejército aliado contra Hitler.
} 
pretendían con sus publicaciones no era difundir una serie de contenidos informativos o de tono grave, sino cumplir más bien con una función de evasión de lo conocido y lo cotidiano, junto con la enseñanza de una serie de valores instructivos y de marcado carácter didáctico-moral.

\section{GLOSARIO}

afera 'aferra, agarra, atrapa'

agásh 'hagáis'

akeos 'aquellos'

hadjilik 'peregrinación'

alesharmos 'alejarnos'

babás 'ocas, gansos'

danyatesh 'dañasteis'

endjunto 'junto a'

gainas 'gallinas'

indianas 'pavos'

kale 'hace falta, es indispensable'

kastelyanas 'castellanas'

kavza 'causa'

kedó 'cesó, paró'

kolorado 'rojo'

kuartier 'barrio'

luvia 'lluvia'

manka 'falta'

meldadores 'lectores'

milyonista 'millonario'

pensativle 'pensativa'

rakontos 'narración de un suceso imaginario, cuento'

rekojgo 'colección'

rubio aquí 'amarillo'

shastre 'sastre'

topatesh 'encontrasteis'

trespil 'especie de rosario o sarta de cuentas que usan los musulmanes'

vedre 'verde'

vierbos 'palabras' 


\section{BIBLIOGRAFÍA}

Abrevaya Stein, S. (2004): Making Jews Modern: the yiddish and ladino press in the Russian and Ottoman Empires, Bloomington, Indiana Univ. Press.

Alexander, T. (1989): The treasure of our fathers: judeo-spanish tales, Jerusalén, Misgav Yerushalayim.

Benbassa, E. y A. Rodrigue (2004): Historia de los judíos sefardíes. De Toledo a Salónica, Madrid, Abada Editores.

Camarena, J. y M. Chevalier (2003): Catálogo tipológico del cuento folklórico español, Alcalá de Henares, Centro de Estudios Cervantinos.

Camarena, J. y M. Chevalier (1997): Catálogo tipológico del cuento folklórico español: cuentos de animales, Madrid, Gredos.

Chevalier, M. (1983): Cuentos folklóricos españoles del Siglo de Oro, Barcelona, Crítica.

Crews, C. M. (1979): “Textos judeo-españoles de Salónica y Sarajevo con comentarios lingüísticos y glosario", Estudios Sefardies 2: 91-258.

Crews, C. M. (1935): Recherches sur le judéo-espagnol dans les pays balkaniques, París, E. Droz.

Díaz-Mas, P. (2009): Los sefardíes. Historia, lengua y literatura, Barcelona, Riopiedras.

Díaz-Mas, P. y C. de la Puente (2007): Judaísmo e Islam, Barcelona, Ares y Mares.

Díaz-Mas, P. y M. Sánchez Pérez (2010): Los sefardíes ante los retos del mundo contemporáneo. Identidad y mentalidades, Madrid, CSIC.

Espinosa, A. M. (2009): Cuentos populares recogidos de la tradición oral de España, Madrid, CSIC.

Espinosa, A. M. (1946): Cuentos populares de España, Buenos Aires, Espasa-Calpe.

Franco, M. (1897): Essai sur l'Histoire des Israélites de l'Empire Ottoman depuis les Origines Jusqu'a nos Jours, París, Libraire A. Durlacher.

Gaon, M. D. (1965): A Bibliography of the Judeo-Spanish (Ladino) Press, Jerusalén, Ben Zvi Institute \& The Hebrew University, [en hebreo].

Haboucha, R. (1992): Types and motifs of the Judeo-Spanish folktales, Nueva York-Londres, Garland.

Hassán, I. M. (1966), “El estudio del periodismo sefardí”, Sefarad 26: 229-235 [reseña del libro, en hebreo de M. D. Gaon (1965)].

Koen Sarano, M. (2000): Kuentos salados djudeo-espanyoles, Valencia, Edisiones Capitelum.

Koen Sarano, M. (1995): De Saragosa a Yerushaláyim: kuentos sefaradís, Zaragoza, IberCaja.

Koen Sarano, M. (1991): Djoha ke dize? Kuentos populares djudeo-espanyoles, Jerusalén, Kana.

Koen Sarano, M. (1986): Kuentos del Folklor de la Famiya Djudeo-espanyola, Jerusalén, Kana.

Larrea Palacín, Arcadio de (1952-1953): Cuentos populares de los judíos del norte de Marruecos, Tetuán, Editora Marroquí. 
Liebl, C. (2010), "Avie úne vez... Julius Subak, Max A. Luria and phonographic field research among Sephardic communities in the Balkans", en P. Díaz-Mas \& M. Sánchez Pérez (eds.) (2010): 237-246.

Liebl, C. (2009): Judeo-Spanish from the Balkans: The Recordings by Julius Subak (1908) and Max A. Luria (1927) (=Sound Documents from the Phonogrammarchiv of the Austrian Academy of Sciences: The Complete Historical Collections 1899-1950, Series 12/OEAW PHA CD 28), Viena.

Lleal, C. (1992), El judezmo. El dialecto sefardí y su historia, Barcelona, Universitat de Barcelona.

Luria, M. A. (1930): A Study of the Monastir Dialect of Judeo-Spanish Based on Oral Material Collected in Monastir, Yugo-Slavia, Nueva York, Instituto de las Españas en los Estados Unidos.

Mazower, M. (2009): La ciudad de los espíritus: Salónica desde Suleimán el Magnífico hasta la ocupación nazi, Barcelona, Crítica.

Mazower, M. (2001): Los Balcanes, Barcelona, Mondadori.

Méchoulan, H., ed. (1992): Les Juifs d'Espagne. Histoire d'une diaspora (1492-1992), París, Liana Levi. Traducido al español en: H. Méchoulan, ed., Los judíos de España. Historia de una diáspora (1492-1992), Madrid, Trotta, 1993.

Miralles Maciá, Lorena. (2009): “Motivos filo-esópicos en el Midrás. Fábulas y anécdotas de rabinos en Levítico Rabbá 22,4", Sefarad 69:2: 281-302.

Morcillo Rosillo, Matilde (1997): “La comunidad sefardí de Salónica después de las guerras balcánicas (1912-1913)”, Sefarad 57:2: 307-332.

Nehama, J. (1935-1978): Histoire des Israélites de Salonique, Salónica, Molho, 7 vols.

Rodrigue, A. (1990): French Jews, Turkish Jews: The Alliance Israélite Universelle and the Politics of Jewish Schooling in Turkey. 1860-1925, Bloomington, Indiana University Press.

Romero, E. (1992): La creación literaria en lengua sefardí, Madrid, Mapfre.

Sánchez Pérez, M. (2010): “Entre escritura y oralidad: cuentos tradicionales en el periódico sefardí Yerushalayim (1909)", en P. Díaz-Mas \& M. Sánchez Pérez (eds.) (2010): 193-202.

Thompson, S. (1955-1958): Motif-Index of Folk-Literature. A Classification of Narrative Elements in Folktales, Ballads, Fables, Mediaeval Romances, Exempla, Fabliaux, Jestbooks and Local Legends, Copenhague-Bloomington, Indiana University.

Tsircas, S. (2001): Ciudades a la deriva. Trilogía, edición de Ioanna Nicolaidou, traducción de Vicente Fernández González et al., Madrid: Cátedra.

Wagner, M. L. (1930): “Caracteres generales del judeoespañol de Oriente”, anejo 12 de la Revista de Filología Española.

Wagner, M. L. (1914): Beiträge zur Kenntis des Judenspanischen von Konstantinopel, Viena, Alfred Hölder 


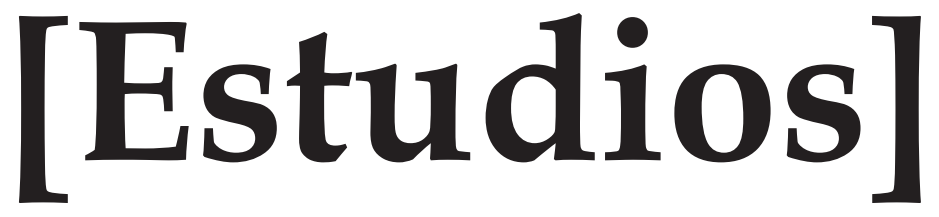





\title{
FRANCISCO AYALA Y EL HUMANISMO DEL EXILIO
}

\author{
INMACULADA LÓPEZ CALAHORRO
}

Universidad de Granada

\begin{abstract}
Resumen
Francisco Ayala fue editor de las revistas Realidad y La Torre, así como de la Biblioteca de Cultura Básica de la Universidad de Puerto Rico. En ellas se reseñan primeras traducciones al español de libros fundamentales sobre las antiguas Grecia y Roma, o reflexiones sobre el humanismo y su vinculación con la Antigüedad. En este artículo repasamos estas publicaciones y nos acercamos a las figuras de los autores, que compartirán el destino del exilio.
\end{abstract}

\section{Palabras clave}

Humanismo, exilio, traductores, Grecia, Roma, Francisco Ayala.

\begin{abstract}
Francisco Ayala was an editor of the magazines Realidad and La Torre and also of the Biblioteca de Cultura Basica of the University of Puerto Rico. There, he reviews first translations into Spanish of fundamental books on Ancient Greece and Rome, or reflections on Humanism and its relationship to Ancient Times. In this paper we look through these publications and pay attention to the authors who will share with him the destiny of exile.
\end{abstract}

\section{Key words}

Humanism, exile, translators, Greece, Rome, Francisco Ayala.

\section{Entre suelo y subsuelo, mientras tanto, una espesa humanidad -nosotros- se aglomera, se afana, se desvive. (Francisco Ayala, “Entre palomas y ratas", otoño de 1948).}

\section{INTRODUCCIÓN}

El exilio es un tiempo y un espacio que determina y transforma la vida de cuantos intelectuales encontraron en el continente americano la salida individual a los totalitarismos que invadieron Europa al final de la primera mitad del siglo XX. Con el exilio se sucede la paradoja de que, lejos de considerarse víctimas de tales circunstancias, parte de estos intelectuales lo interpretó como una oportunidad que los

\footnotetext{
${ }^{1}$ Correo-e: inmlop@ugr.es. Recibido: 12-09-1912. Aceptado: 11-12- 2012.
} 
liberaba de comportamientos rígidos y consensuados, de modo que se encontraban ante una oportunidad para replantearse reflexiones más libres sobre el vínculo del yo con la colectividad, o del yo con la herencia cultural e ideológica². Son las palabras del pedagogo republicano Lorenzo Luzuriaga, con quien Francisco Ayala conformará la dirección oficiosa de la revista Realidad: "Nosotros no somos exiliados. Exiliados son los que han quedado allí, sin libertad y sin posibilidades de tenerla por toda una generación" (C. Lozano Seijas apud García Montero, 2007: XXXVI).

De igual manera, Francisco Ayala, desde una posición estoica que lo protege de la nostalgia del recuerdo, vive el exilio como una oportunidad que le permite participar "íntegramente en el discurso clásico sobre el humanismo", en el que se produce la tensión entre la universalidad de principios que conforman el patrimonio humano ('homo universalis') y la conciencia de fragilidad del individuo (Navajas, 2006: 704-706). Esta clara relación con el humanismo de herencia clásica se reflejará en un diálogo directo entre los textos de la Antigüedad y el presente de estos intelectuales. La tragedia griega, el pensamiento griego o figuras romanas como Cicerón, cobrarán una actualidad que no precisará ya de la herencia vertical para justificarse. La traducción por primera vez al español de libros fundamentales para el conocimiento de la Antigüedad será un instrumento imprescindible para este cambio de relación con el pasado al tiempo que se reivindica el valor de la cultura occidental.

En este sentido, la labor que Francisco Ayala realizó como editor fue de gran valor, puesto que, sumándose al impulso de grandes editoriales como Fondo de Cultura Económica ${ }^{4}$, permitirá que se divulgue la labor de grandes intelectuales que en este período histórico aportaron reflexiones o trabajaron sobre textos de las antiguas Grecia y Roma, identificados, además, con el discurso ideológico posterior a la Segunda Guerra Mundial. Serán los nombres de Wenceslao Roces, Werner Jaeger, Karl Kerényi,

\footnotetext{
${ }^{2}$ Para esta introducción sobre el exilio y la relación con el humanismo, consideramos esencial el artículo de Gonzalo Navajas (2006), titulado "La escritura de la libertad y la cultura industrial en Francisco Ayala." Aunque nos detenemos en citas puntuales, señalamos los subtítulos del artículo: "I. Humanismo e historia cultural, II. El yo y la supraindividualidad, III. La literatura en la cultura industrial de masas, IV. Conclusión. El exilio como apertura." Asimismo, la introducción que, bajo el título "La aventura de pensar el mundo", escribe Luis García Montero (2007) para la edición facsímil de la revista Realidad.

3 "El perfil intelectual de Ayala no opera en el vacío ni le corresponde exclusivamente a él. Es propio de la figura del intelectual de entreguerras que experimenta la primera gran crisis del paradigma de la cultura moderna afiliada todavía con el humanismo clásico. [...] Para Spengler, la amenaza se concreta en la fuerza anónima y ciega de las sociedades periféricas dentro del marco occidental, es decir, aquellas culturas no conectadas directamente con el modelo greco-latino. [...] Francisco Ayala queda inserto en estos parámetros y hace una aportación específica dentro de ellos. Su posición epistemológica y ética más comprensiva se fundamenta en la independencia del yo individual frente a los modelos supraindividuales totalizantes" (Navajas, 2006: 703). Asimismo, sobre el humanismo de Ayala, cf. García Jurado (2008: 22-23) y López Calahorro (2008: 26).

${ }^{4}$ Sobre el impulso de esta editorial es fundamental la figura de José Medina Echavarría, compañero y amigo de Francisco Ayala en la Secretaría de Cortes, también exiliado con motivo de la Guerra Civil, y persona fundamental para su posterior relación con la Universidad de Puerto Rico. Echavarría en su primer destino en México se encargó de convertir a la Editorial Fondo de Cultura Económica en una editorial de prestigio (Sánchez Montes, 2006: 89), de lo que damos muestra en este trabajo por los títulos de las obras citadas.
} 
Ludwig Schajowicz, o Roger Labrousse, los que en este trabajo presentaremos como testimonio de esta cuestión.

\title{
2. BUENOS AIRES. REALIDAD (REVISTA DE IDEAS)
}

Durante su exilio en Buenos Aires (1939-1950), Francisco Ayala acepta la propuesta de dirigir una nueva revista de discusión intelectual, a la que sellamó Realidad (Revista de Ideas). Su primer número se publicó en los meses de enero-febrero de 1947 bajo la dirección de Francisco Romero, a propuesta del propio Ayala ${ }^{5}$. No obstante, en la dirección oficiosa estaban Francisco Ayala y Lorenzo Luzuriaga, miembros asimismo del consejo de redacción junto con Amado Alonso, Eduardo Mallea, Ezequiel Martínez Estrada, Julio Rey Pastor y Guillermo de la Torre. Esta revista se publicó entre enerofebrero de 1947 y septiembre-diciembre de 1949, con un total de 18 números. La idea era que la revista tuviera "sesgo ensayístico o crítico" (Ayala, 1988: 343), pero sobre todo fue el instrumento utilizado para la discusión sobre "la defensa de las raíces democráticas del pensamiento occidental” (García Montero, 2007: XLI) al tiempo que se propiciaba el hecho más cercano o coyuntural. Frente al Occidente víctima de los totalitarismos políticos, Realidad enarbola "la capacidad cultural y moral del ser humano" (ibid.). El editorial del primer número, bajo la pluma de Francisco Romero y Francisco Ayala (García Montero, 2007: XXXIX), da cuenta de la dimensión universal y de conciencia histórica que tenía la creación de esta revista de ideas:

\begin{abstract}
El Occidente debe alcanzar conciencia de sí, de sus raíces y fundamentos, de lo que en él es accidente y de lo que es esencia, de su médula viva, de sus limitaciones y de sus posibilidades. Debe también abarcar su crisis, entenderla, juzgarla, arbitrar los medios para salir de ella. Esto, en cuanto a lo que pudiera llamarse el aspecto interno. En cuanto a lo externo, debe examinar la nueva situación, abrirse a una comprensión más generosa y cabal de las otras culturas, para respetar en ellas su derecho, para incorporar aquellos de sus valores que resulten admisibles sin desmedro de la peculiaridad propia, para corregir lo que, acá y allá, hubiera de angosto y unilateral. Una cultura no se impone a quienes no la tengan por propia; únicamente es legítimo proponerla. [...] Acaso el porvenir de la humanidad en los siglos próximos -o el porvenir de la humanidad, sin más, penda en esta solemne ocasión de que la propuesta de Occidente sea aceptada. Y ello depende, a su vez, de que resulte aceptable. (Realidad, 2007: 19-20) ${ }^{6}$.
\end{abstract}

Sobre la calidad de la revista Francisco Ayala escribirá que “cuando alguna vez, por uno $u$ otro motivo, hojeo sus páginas, veo que contienen trabajos de muy

\footnotetext{
${ }^{5}$ Sobre el nacimiento de Realidad nos dice Ayala: “Quería Mallea, insistiendo mucho en ello, que el director fuera yo, pero me negué en redondo. Me negué, porque si mi repugnancia de siempre a ejercitar cualquier especie de autoridad que hubiese de imponer decisiones a mis semejantes me ha hecho rehuir a lo largo de la vida toda posición de mando, ¿cómo hubiera de haber aceptado la titularidad de ese poder irrisorio que faculta para decidir sobre la inserción de tal o cual texto en una publicación, exponiéndome -y más dada mi condición de extranjero- a las fútiles pero implacables iras de los desairados en terreno tan vidrioso como es el de las pretensiones y variedades literarias? Propuse para el cargo a Francisco Romero. [...] Luzuriaga y yo le prometimos que, en calidad de secretarios de redacción, haríamos todo el trabajo; con lo cual terminó él por resignarse a aparecer como director, prestándonos su nombre. Así fue como se hizo realidad la revista Realidad" (Ayala, 1988: 343).
}

${ }^{6}$ Sobre las referencias y citas de la revista Realidad, utilizaremos la paginación de la edición facsímil (Sevilla, Renacimiento, Colección Facsímiles de Revistas Literarias, 2007). En la bibliografía recuperamos la paginación original, así como el año de edición. 
alta calidad y que en ningún momento decayó su nivel" (Ayala, 1988: 346), o que allí confluyeron las "mejores firmas del mundo en aquellos momentos. Ingleses, alemanes, incluso portugueses" (Núñez, 2008: 175). Tales firmas concretadas en artículos o reseñas de libros sobre estudios o temáticas de las antiguas Grecia y Roma son:

J. L. R. ${ }^{7}$, “Teodoro Mommsen, El mundo de los Césares, Ed. 'Fondo de Cultura Económica', México, 1945”, Realidad, vol. I, 1, 1947, 147-148.

Lorenzo Luzuriaga, “Werner Jaeger, Paideía. Los ideales de la cultura griega, Fondo de Cultura Económica, México, 3 vol., 1942-1945”, Realidad, vol. I, 2, 1947, 307-309.

Eduardo González Lanuza, “Eco y narciso: ensayo sobre arte”, Realidad, vol. 1, 3, 1947, 325-339.

José Gaos, “El Aristóteles de Jaeger”, Realidad, vol. II, 4, 1947, 92-98.

Rodolfo Mondolfo, "Benjamín Farrington, Ciencia griega de Tales a Aristóteles, Colección Pingüino, edit. Lautaro, Buenos Aires, 1947", Realidad, vol. II, 6, 1947, 431-433.

J. L. R., "Ludwig Friedländer, La sociedad romana; historia de las costumbres en Roma, desde Augusto hasta los Antoninos, Fondo de Cultura Económica, México, 1947", Realidad, vol. III, 8, 1948, 271-272.

José M $\mathrm{M}^{\mathrm{a}}$ Chacón y Calvo, "Quevedo y la tradición senequista”, Realidad, vol. III, 9, 1948, 318-342.

Francisco Vera, “Beppo Levi: Leyendo a Euclides, Editorial Rosario, Rosario de Santa Fe, 1947", Realidad, vol. III, 9, 1948, 403-405.

Adolfo P. Carpio, “Una traducción de Plotino”, Realidad, vol. V, 13, 1949, 85-89.

Carmen Gándara, "Sócrates, la Naturalidad y la muerte”, Realidad, vol. VI, 16, 1949, 92-95.

Parte de estos intelectuales son exiliados de España o de la Europa de la Segunda Guerra Mundial. Dada la significación de algunos de los estudios o de las mismas figuras en el ámbito de los Estudios Clásicos, realizamos una breve semblanza de ellas y su aportación gracias a la existencia de Realidad, en concreto de Wenceslao Roces, Joaquín Xirau, Werner Jaeger y Karl Kerényi ${ }^{8}$.

\footnotetext{
${ }_{7}^{7}$ Iniciales de José Luis Romero. En estas referencias bibliográficas respetamos la paginación del original.

${ }^{8}$ No nos detenemos, no obstante, en la figura del insigne filósofo italiano Rodolfo Mondolfo, exiliado en Córdoba donde residió desde 1940 a 1947, y posteriormente en Tucumán, desde comienzos de 1948 hasta 1952, y donde coincidirá con otro intelectual europeo exiliado, Roger Labrousse, cuya figura trataremos posteriormente. Sólo añadir sobre la figura de Mondolfo que, considerado como un auténtico humanista y un referente de los Estudios Clásicos en Argentina, además de la reseña citada sobre la obra de Benjamín Farrington, en la revista La Torre, dirigida también por Francisco Ayala en Puerto Rico, publicará "Séneca y la infinitud del progreso espiritual" (Mondolfo, 1954: 63-74), que verá la luz el mismo año en Italia en Critica Sociale (Milano, Aprile, 1954). A Mondolfo, dada la entidad de sus estudios, Diego F. Pró le dedica un libro en dos volúmenes (1967).
} 


\section{Wenceslao Roces}

Exiliado en México y profesor de Derecho y Filosofía en la Universidad Nacional de México, Wenceslao Roces fue una de las figuras más representativas del exilio español. Destaca su labor como traductor para el Fondo de Cultura Económica y a él se le debe, entre un ingente número de traducciones, la primera versión de El capital de Karl Marx o La fenomenología del espíritu de Hegel. En cuanto a los textos relativos a las antiguas Grecia y Roma traducidos por Wenceslao Roces, en Realidad se reseñan los siguientes ${ }^{9}$ :

“Teodoro Mommsen, El mundo de los Césares, Ed. 'Fondo de Cultura Económica', México, $1945^{\prime \prime 10}$.

Es una 'nota de libros' realizada por José Luis Romero. En la reseña Romero destaca que "el título de este libro no es el de original de Mommsen, el gran historiador alemán que renovó los estudios romanos" (Romero, 2007: 165). Nos explica asimismo que, con el título El mundo de los Césares, Wenceslao Roces recoge la obra de Mommsen "Las provincias desde César hasta Diocleciano y completada su Historia Romana" (ibid.). Las provincias desde César hasta Diocleciano ${ }^{11}$, publicado en 1885, es el quinto volumen de Historia de Roma ${ }^{12}$, siendo esta traducción de Roces la primera versión en lengua castellana de este volumen. Incorpora el traductor una selección de textos de los tres primeros libros de Historia de Roma. Para Romero la selección del traductor debería haberse ajustado a la "forma original de las obras que se traducen, tanto para facilitar su consulta como para no inducir a error a los lectores" (ibid.). No obstante, el valor de la obra queda claramente expuesto, no sólo por el de la traducción y la selección, sino por poner al alcance de los lectores y estudiosos en lengua hispana una de las obras más importantes sobre la antigua Roma:

Una traducción excelente permite una lectura provechosa de este libro por tantos motivos interesantes. Y, pese a la objeción señalada, el lector culto no dejará de agradecer al editor el que haya incorporado al volumen los capítulos de la Historia Romana a que nos hemos referido. (ibid.: 166).

"Ludwig Friedländer, La sociedad romana; historia de las costumbres en Roma, desde Augusto hasta los Antoninos, Fondo de Cultura Económica, México, 1947."

\footnotetext{
${ }^{9}$ Junto a la descripción que realizamos de los libros reseñados, dada su importancia en el ámbito de los Estudios Clásicos, indicamos que de las traducciones sobre temas de Grecia y Roma, además de los expuestos, Roces realizó las siguientes traducciones: Droysen, Johan Gustav, Alejandro Magno, México, FCE, 1946 (481 p.); Gregorovius, Ludwig, Atenas en la Edad Media y otros ensayos, (Prólogo de W.R.), México, FCE, 1946 (417 p.); Mayr, Robert von, Historia del Derecho Romano, Barcelona, Labor, 1931 (2 vol.); Rohde, Edwin, Psique: la idea del alma y la inmortalidad de los griegos, México, FCE, 1948 (368 p.); Sohm, Rudolf, Instituciones de Derecho Privado Romano: historia y sistema, Madrid, RDP, 1928 (711 p.). Citamos por la página de la web de la Fundación Wenceslao Roces.

${ }^{10}$ Las referencias bibliográficas son citadas tal y como aparecieron en Realidad.

${ }^{11}$ Su título original es: Das Römische Imperium der Cäsaren. Römische Geschichte.

12 Römische Geschichte, escrita entre 1854-1856, traducida al español en 1876 por Alejo García Moreno como Historia de Roma. Para la figura de Alejo García Moreno, cf. Mirilla Romero (2005: 135-152).
} 
Su título original es Darstellungen aus der Sittengesch. Rom's in der Zeit von August bis zum Ausgang der Antonine (3 vol., 1862-71; 6th ed., 1889-90). En la revista Realidad (vol. III, 7, 1948, sin número de página) la editorial Fondo de Cultura Económica anuncia el libro de Friedländer:

Magnífica traducción de una de las obras más famosas de la literatura histórica, aparecida bajo el título de "Cuadros de historia de las costumbres romanas, hermosamente ilustrada con 42 láminas a toda página, encuadernada... \$ 40 .

Es en el número siguiente (III, 8, 1948, 403-405) donde aparece la reseña de José Luis Romero sobre el libro con la traducción de Roces. Resalta Romero que, casi un siglo después de que saliera a la luz, se traduce al español la gran obra del erudito alemán. Friedländer, seguidor de Teodoro Mommsen y de Jacob Burckhardt, escribió este libro en un momento posterior a la crisis de 1848, razón por la que los historiadores cambiaron el contenido histórico político anterior. Así nos explica Romero las características que hacen de la obra de Friedländer un texto fundamental para conocer la Antigüedad y la importancia de que por primera vez se traduzca al español, prácticamente un siglo después de su publicación:

Grandes cuadros de conjunto en los que correspondieron al pueblo un papel de primer plano, mostrando sus formas de vida y las alternativas de su actitud frente a las figuras singulares que parecían dirigir la vida social. [...]. Así surgió, de un conjunto, no muy orgánico por cierto, lo que se empezó a llamar, sin demasiada precisión, por lo demás, historia de la cultura o de la civilización.

Dentro de esta corriente, que despertaba en su tiempo, se orientó Ludwig Friedländer, y fruto de sus investigaciones en ese sentido fue su notable libro sobre la sociedad romana que acaba de publicarse en México, traducido por primera vez al español. (Romero, 2007: 1377).

\section{Wenceslao Roces, Joaquín Xirau y Werner Jaeger}

"Werner Jaeger, Paideía. Los ideales de la cultura griega, Fondo de Cultura Económica, México, 3 vol., 1942-1945."

Paideía es uno de los textos fundamentales de análisis de la cultura griega en torno al complejo concepto griego que da título al libro, cuyo alcance es mucho más amplio de lo que podríamos traducir en nuestra lengua como "educación". Publicada en Fondo de Cultura Económica, la primera edición en español de 1942 consta de un prólogo del autor alemán ${ }^{13}$. En él da gracias a Joaquín Xirau como traductor, que así lo fue de los libros I y II, pero su anticipada muerte hizo que Wenceslao Roces tradujera los libros III y IV, por lo que no es mencionado en el prólogo. La edición en tres volúmenes que reseña Romero se sucede entre los años 1942 y 1945, siendo los libros III y IV publicaciones por primera vez del original alemán también inédito y con la traducción al español. La primera edición en un único volumen será muy posterior, de 1957.

Joaquín Xirau es también un exiliado de la Guerra Civil española, de origen catalán y afincado en México. Discípulo de la Institución Libre de Enseñanza, decano de la Facultad de Filosofía de Barcelona, huyó hacia Francia en la misma ambulancia

\footnotetext{
${ }^{13}$ La primera edición en alemán, en 1933, y una segunda, en 1935, tienen también prólogos de W. Jaeger.
} 
que Antonio Machado. Representa Xirau la figura de un auténtico pedagogo que se ocupó profundamente de los métodos de enseñanza. Seguidor de su admirado Ramón Llul, escribirá citándolo: "El amor ha sido creado para pensar" (Xirau, 1996). Es, por consiguiente, un auténtico humanista, que en su exilio en México adquirió una nueva forma de mirar los estudios humanísticos, tal y como su hijo Ramón Xirau (2006) nos relata sobre su memoria:

Mi padre me dijo y dijo a varios de nosotros que en México había descubierto a España. Otra España, en efecto; la de los humanistas, la de Vives, la de Sahagún, Las Casas, Vasco de Quiroga. En todos ellos hay algo de común y de valor especialmente importante en nuestros días de desvalor, el "orden del amor".

Sobre la trascendencia de los estudios de Xirau en el ámbito de la educación, Antoni Mora reivindica su figura precisamente a la luz de la palabra griega, titulando "La paideía republicana de Joaquín Xirau" al prólogo del Tomo III de sus obras completas (Mora, 2000: XI-XX), en el que establece la relación y la diferencia entre el concepto 'educación' de Xirau y el de Jaeger. Es así que se establece una línea de comunicación indirecta entre la Antigüedad y la actitud activa filosófica, política y pedagógica del pedagogo catalán.

En cuanto al libro de Jaeger, recordamos que no es sólo un estudio sobre la antigua Grecia, sino también un análisis que trasciende la cultura europea e igualmente transmisor del compromiso humanístico de su autor. Para ello nos sirven las palabras del autor en el prólogo de la edición española, escrito en la Universidad de Harvard en julio de 1942, adonde se había exiliado el alemán huyendo del nazismo. En el prólogo, en el que hace referencia a la primera edición que correspondía al período de entreguerras, dice:

Este libro se escribió durante el período de paz que siguió a la primera Guerra Mundial. Ya no existe el "mundo" que pretendía ayudar a reconstruir. Pero la Acrópolis del espíritu griego se alza como un símbolo de fe sobre el valle de la muerte y destrucción que por segunda vez en la misma generación atraviesa la humanidad doliente. (Jaeger, 1962: X).

Desde esa mirada que sobrevuela lo que acaece en el tiempo contemporáneo del autor a causa de las dos guerras mundiales, de las que la sucesiva redacción de los libros que conforman Paideía son testimonio, es el también pedagogo y colaborador de Francisco Ayala, Lorenzo Luzuriaga, el encargado de la reseña para Realidad. De sus palabras destacamos la valoración que hace del libro de Jaeger por su actualidad:

Cuando se buscan los orígenes de las ideas e instituciones esenciales de nuestra cultura, siempre venimos a parar, por un camino $\mathrm{u}$ otro, a la fuente cristalina de Grecia. Alguien ha dicho, en este sentido, que excepto las fuerzas ciegas de la naturaleza, nada se mueve en el mundo que no sea griego en su origen. Así vemos, por ejemplo, que los ideales políticos-pedagógicos que han estado en pugna últimamente y que aún lo están en cierto modo: el totalitario y el democrático liberal tienen sus antecedentes remotos, pero manifiestos de la educación helénica: la espartana y la ateniense. A pesar de todas las aparentes diferencias, estas concepciones se corresponden de un modo tan manifiesto con aquellos ideales, que es raro que no se haya reconocido antes esa coincidencia. De aquí que el estudio de la cultura clásica tenga un valor permanente, ya que nos permite ver en su originaria pureza las ideas que predominan en la vida de nuestra época. (Luzuriaga, 2007: 347). 
Esta conciencia de la comparación entre los dos tiempos, entre el de la Antigüedad y el de la época que viven los exiliados en Argentina, producto de los conflictos bélicos que asolan Europa, es fundamental en los análisis que de la realidad hace también Francisco Ayala utilizando las referencias del mundo clásico. Cuando en 1978, casi treinta años después, escribe el prólogo para la edición de El tiempo y yo, o el mundo a la espalda, comprobamos el ejercicio de una relación semejante a la expuesta por Luzuriaga en la reseña sobre el libro de Jaeger, con la conciencia de la permanencia de la cultura clásica por su actualidad:

\begin{abstract}
Por ejemplo: lo inaudito de una noticia leída en el periódico matutino que nos ha escandalizado por lo pronto como muestra increíble de la locura de nuestros tiempos, puede llevarnos hacia un texto clásico donde lo referido en el diario encuentra su parangón. Con esto, la trivialidad del suceso publicado hoy para que mañana esté olvidado adquiere, sobre el fondo del texto latino, la dignidad de una permanencia que lo hace perenne, mientras que a su vez el texto viejo y distante, apergaminado, se nos hace actual al sufrir ante nuestros ojos la invasión de una sangre caliente. (Ayala, 2006: 16).
\end{abstract}

\title{
Karl Kerényi
}

En los números 7 y 9 del volumen III de Realidad, en 1948, se publica la conocida "Carta sobre el humanismo" de Martin Heidegger"14 (2007: 1091-1115 y 1467-1491). Entre ambas partes en que se divide el texto de Heidegger, se publicará “El humanista en la encrucijada" de Karl Kerényi (2007: 1253-1263). Sobre su figura en el artículo publicado en Realidad, en nota a pie de página se señala: "Profesor de la Universidad de Budapest, es uno de los más prestigiosos especialistas actuales en Mitología e Historia de las religiones" (ibid.: 1253). Kerényi (1897-1973), doctor en Filología clásica por la Universidad de Budapest, alumno visitante en distintas Universidades y de los prestigiosos filólogos clásicos Eduard Norden y Ulrich von Wilamowitz-Moellendorff, desertor político en 1944 cuando los nazis entraron en Hungría, víctima asimismo del estalinismo y exiliado finalmente en Suiza donde conseguirá la nacionalidad y desarrollará parte de sus estudios, es uno de los grandes eruditos de los humanistas de la Antigüedad y uno de los fundadores de los estudios modernos sobre mitología. Junto con Carl Gustav Jung escribió Introducción a la esencia de la mitología (1941).

Kerényi en "El humanista en la encrucijada”, firmado en Budapest (invierno 1947/48), destaca la contraposición entre la humanitas y lo "inhumano"15, y repasa el concepto 'humanismo' en las antiguas Grecia y Roma, para reclamar el papel esencial que ha de ejercer el filólogo clásico contemporáneo, más allá del ejercicio de la investigación histórica:

Ahora sí debe hablar el filólogo, precisamente por tener conciencia de su ocupación, no es idéntica al 'humanismo' en su sentido más amplio tal como lo definimos antes; y más aún: de

\footnotetext{
${ }^{14}$ La traducción de la obra de M. Heidegger, "Carta sobre el humanismo", se debe a A. Wagner de Reyna, publicado en Realidad ( 7-9, 1948).

15 “Hoy día, cuando hemos abandonado hasta la idea de que pueda proyectarse alguna claridad desde la humanitas hasta su polo opuesto, ha llegado la hora y la tensión en lo inhumano, en favor del humanismo como tal y para los estudios humanísticos o, mejor, lo que ha quedado en pie de estos estudios como investigación científica de la Antigüedad" (Kerényi, 2007: 1255).
} 
que esa ocupación, humanística sólo por su origen, en cuanto investigación histórica ha perdido desde hace tiempo aquel apasionado interés por el hombre que caracteriza y caracterizará al 'humanista' mucho más que el conocimiento del latín y el griego. (Kerényi, 2007: 1255).

Son reseñables sus conclusiones que relacionan el humanismo tanto por semejanza como por diferencia con su valor en la Antigüedad:

También este humanismo buscaba soluciones en la Antigüedad: soluciones de la problemática de la formación, no meramente del ser hombre. Por aquel entonces todavía no se impuso la evidencia de que en lugar del hombre puede presentarse de repente también el no-hombre. Tuvo que llegar la segunda guerra mundial para que, como alusión al menos, el gran filólogo Karl Reinhardt, formulara la presunción de que la solución clásica se origina allí donde 'se lucha por la imagen del hombre amenazada'" (Kerényi, 2007: 1263).

Uno de los elementos fundamentales de conexión con la obra de Francisco Ayala viene determinado por el uso del precepto socrático-délfico 'conócete a ti mismo'. Kerényi, a propósito de Sócrates, dice, utilizando al filólogo como sujeto:

La sentencia délfica 'conócete a ti mismo' lo remite a una cuestión que habría de resolverse antes que ninguna otra, y a la que él todavía no puede contestar: si acaso él, el hombre Sócrates, no es un monstruo más complicado y más monstruoso aún que el fenomenal Tifeo. ¿O acaso él, el hombre, es un ser más suave y más sencillo, que participa en algo divino y no-monstruoso? (Kerényi, 2007: 1258).

Esta sentencia estará presente en Francisco Ayala como principio rector (López Calahorro, 2008: 153-160). Es, quizá, el elemento fundamental con el que el intelectual refleja su compromiso vital individual, su medida humana, lo que en otro lugar hemos llamado 'humanismo inapelable' (López Calahorro, 2008: 26) ${ }^{16}$. Pero también hay otros puntos de encuentro entre el filólogo y Francisco Ayala, de modo que, al repasar Kerényi el concepto humanismo, incorpora las aportaciones procedentes de los autores griegos y romanos como Terencio, Menandro o Platón, y tras ellos aparece la gorgona Medusa:

Tenemos que leer estos tristes signos. Y con ello cobra vida el rostro de la gorgona que estaba siempre ante nuestros ojos sin que nos diéramos cuenta. Emerge, por así decirlo, y actúa. Espero que actúe de un modo bien distinto al de la mitológica cabeza de medusa: ésta paralizaba a todo lo viviente, mientras que la nueva debiera liberar lo paralizado. (Kerényi, 2007: 1260).

Publicado el texto de Kerényi en 1948, destacamos la similitud en el uso de medusa que nos expone Francisco Ayala en su ensayo "Calderón. Porque no sepas que sé", publicado en $1961^{17}$. En este texto Ayala refleja una contradicción similar a la de Kerényi sobre la acción paralizante de la gorgona, al reclamar que su acción sea liberadora en lugar de paralizadora, relatividad que en Ayala se reflejará en un doble sentido: tanto en la ambigüedad de quien es agente portador de la mirada paralizante ${ }^{18}$,

\footnotetext{
${ }^{16}$ Sobre el humanismo de Ayala: “Ahí, en esa individualidad que tan cara cuesta, es donde veo que radica el 'humanismo inapelable' de Ayala. Cicerón y Aulo Gelio hablaron sobre la dimensión de la humanitas. La medida humana se ha visto terriblemente amenazada en el siglo XX. Pero Ayala no puede ser entendido sin esa medida específicamente humana. Como ha visto Inmaculada, la mejor expresión de esta medida es el socrático (délfico) 'conócete a ti mismo' “ (García Jurado, 2008: 23).

${ }^{17} \mathrm{El}$ texto están incluido en La plumas del fénix (Ayala, 2007).

${ }^{18}$ En su ensayo "Porque no sepas que sé", refleja el aspecto contemporáneo de esta mirada de Medusa: "Segismundo quiere exterminar al intruso, quiere quebrar el espejo de la conciencia ajena, porque se siente degradado a sus ojos. La vista del extraño, del otro, es siempre mirada de Medusa, que nos petrifi-
} 
o la mirada también liberadora de la conciencia, más exactamente interrogadora, que podrá ser la cabeza del cordero, en el relato que lleva este nombre (López Calahorro, 2010).

\section{PUERTO RICO. LA TORRE Y BIBLIOTECA DE CULTURA BÁSICA}

De Argentina marcha Francisco Ayala a Puerto Rico, donde ocupará la plaza de Catedrático de Ciencias Sociales y dirigirá el Servicio de Publicaciones ${ }^{19}$. A Puerto Rico llega para dar un curso en la Universidad y allí, por encargo del rector de la Universidad, Jaime Benítez, el escritor pondrá en marcha, en colaboración con la Revista de Occidente, la colección Biblioteca de Cultura Básica de la Universidad de Puerto Rico ${ }^{20}$. También dirigirá una nueva revista, La Torre, que actualmente se sigue editando. Ambas empresas se fundarán en 1953 y en ninguna de ellas, tal y como había ocurrido en Realidad, aparecerá el nombre de nuestro escritor (García Montero, 2009: 121-122).

En La Torre destacamos la presencia de dos eruditos de la mitología moderna: Ludwig Schajowicz y Mircea Elíade. Durante el período en que Francisco Ayala dirige la revista La Torre, se publica “Orfeo y Anfión" de Schajowicz (1954) y otro artículo de mitología a cargo del Eliade, "Los mitos en el mundo moderno" (1954). Ambos títulos se presentan en números sucesivos de la revista, en concreto en los números 5 y 6, respectivamente. Sobre la figura del rumano Mircea Eliade, anotamos también su condición de exiliado con motivo de la Segunda Guerra Mundial, instalándose primeramente en París y posteriormente en Chicago. Su amplísima bibliografía da cuenta de su talla intelectual y de sus amplios e innovadores conocimientos, especialmente en el ámbito de la mitología.

En cuanto a Ludwig Schajowicz, de origen austriaco, en 1938 emigró a Cuba, donde fundó el Teatro Universitario de la Habana. Posteriormente marchó en 1947 a Puerto Rico como invitado para impartir unas conferencias, y donde se estableció hasta su muerte como Catedrático de la Universidad. Entre sus obras destacamos Mito y existencia (1962) y El mundo trágico de los griegos y de Shakespeare (1990). Mito y existencia está pensado treinta años antes de su publicación, es decir, incluso antes del

ca y convierte en objeto. ¿Quién en el mundo habrá sido tan dichoso que nunca haya sentido el impulso de aniquilar -siquiera sea a su vez con la mirada- al que nos ha sorprendido acaso en un momento de debilidad? [...] Todo esto, que en nuestros días ha puesto muy de relieve el análisis existencial, se encuentra expresado con fórmula definitiva en los dos versos de Calderón" (Ayala, 2007: 771).

19 “Jaime Benítez [...] me propuso que me quedara con un contrato permanente para organizar el curso básico de ciencias sociales. Al año siguiente me encomendó la dirección de la editorial universitaria para desarrollar un programa de publicaciones bastante amplio, dentro del cual fundé y puse en marcha una revista. La Torre, que ha sido por varios años la mejor publicación de su género en lengua castellana" (Ayala, 1988: 353).

20 “A mi llegada a Puerto Rico fui encargado de reorganizar el curso básico de ciencias sociales [...]; pero ya al año siguiente me propuso el rector que me hiciera cargo de la Editorial Universitaria y planease un programa en cooperación con la Revista de Occidente, y por cierto, que si esto comportaba un enriquecimiento cultural para aquel país, la ventaja económica fue para Ortega y su familia. Sería casi un alarde de parte mía la mera enumeración de las obras que se publicaron en un breve lapso" (Ayala, 1988: 378). 
ensayo "Orfeo y Anfión", al que citaría en su publicación posterior. En el prólogo de la edición de 1962, con fecha de abril de 1961, editado también por la Universidad de Puerto Rico, Schajowicz anota:

Este libro es la versión revisada y considerablemente ampliada de un trabajo que terminé a principios de 1958. Algunos capítulos de la primera versión aparecieron en las revistas La Torre (Puerto Rico) y Humanitas (México). (Schajowicz, 1990: 20) ${ }^{21}$.

Carlos Rojas (2005), a propósito de un estudio sobre los 'transterrados' en Puerto Rico, destaca en primer lugar precisamente al intelectual austriaco. Profesor en este país de varias generaciones de estudiantes, seguidor de Nietzsche y de Heidegger, Schajowicz restituye el pensamiento mítico griego frente al monoteísmo religioso, de modo que para él "el mito es la verdad de la existencia” (Rojas, 2006: 57). La presencia del austriaco se muestra desde el primer número de la revista La Torre con el artículo "La forma interior de la literatura europea" (1953). Después de citar una de las obras fundamentales sobre el análisis de la literatura europea y su relación con la literatura romana -nos referimos a la importante obra de Ernst Robert Curtius, Europäische Literatur and Lateinisches Mittelalter (ibid.: 99)-, Schajowicz reflexiona sobre la relación entre la tragedia griega y la tragedia 'moderna', mostrando el vínculo que permite seguir dotando de actualidad al gran género literario de la Grecia clásica. Para ello el siguiente texto es un buen exponente, en el que se sintetiza y expresa el humanismo de carácter clásico heredado al tiempo que se impregna de contemporaneidad y actualidad. La Antigüedad no es ya sólo un redescubrimiento, sino como dice el autor, es "una imagen latente" que el hombre occidental redescubre en sí mismo:

¿Pero es que existen, acaso, impulsos de la creación específicos del Occidente -aunque sean 'heredados' de la Antigüedad Clásica que tuvieran que objetivarse en obras poéticas totalmente diferentes de las otras culturas? A esto contestaría en sentido afirmativo. Uno de los mejores ejemplos podría suministrárnoslo el género de la tragedia, que, después de su nacimiento, plenitud y muerte en Grecia, volvió a surgir en el Occidente renacentista; éste lo 'aprendió en la escuela de Séneca, lo transformó (Marlowe, Shakespeare) cristianizándolo a veces (Calderón, Racine), y lo incorporó así a su acervo de tradiciones literarias. Pero la posibilidad de la existencia de la tragedia 'moderna' no se debe simplemente al redescubrimiento de este género dramático sino a una determinada predisposición en el hombre occidental, a la imagen latente que había en él de la realidad trágica, de repente desvelada por el nuevo contacto con la Antigüedad. (Schajowicz, 1953: 101-102).

\footnotetext{
${ }^{21}$ O más precisamente su propia cita: “Véase mi ensayo Orfeo y Anfión (La imagen del proto-artista en la poesía moderna), incluido en el $n^{\circ} 5$ de La Torre (Universidad de Puerto Rico, marzo de 1954), donde me refiero a los aspectos trágicos de la existencia del artista (pp. 51-52): 'Lo que éste siente como la más suyo no está sometido a su control, es un pasajero don de poderes celestes, quizás caprichosos y hasta maléficos desde la perspectiva del hombre. El artista es un condenado a la creación, ella le ofrece momentos de súbita euforia pero también le hace pasar por agonías lentas. Como un espectro, amenaza al creador la desesperanza por la lejanía de los dioses. Y hasta la presencia de ellos puede ser una prueba por encima de las fuerzas humanas. ¿No había advertido ya Apolo esta vulnerabilidad y esclavitud del hombre creador cuando se dirigió a las musas después de revelarse a Anfión? ¡Amadle, cuidadle! Pero sabed que para él / ya no hay felicidad... Sólo vive para mí. Le he escogido, como una cima es escogida por el rayo'" (Schajowicz, 1990: 182).
} 
Junto a la revista La Torre se inaugura el otro proyecto de la Universidad de Puerto Rico, la Biblioteca de Cultura Básica, en 1953 con Fausto de Goethe ${ }^{22}$. De la importancia de esta selección, Gregorio Weimberg ${ }^{23}$ escribirá una importante reseña sobre la colección cuatro años después en La revista, de la Biblioteca Nacional de Buenos Aires. Bajo el título “Biblioteca de Cultura Básica” (Weimberg, 1957) el profesor de la Universidad argentina resume lo poco común de las referencias de este carácter global que versan sobre colecciones de obras clásicas, circunscritas normalmente a determinados libros o autores. La razón de ocuparse de la colección en su conjunto se debe a las cualidades que impregnan la selección de cada uno de los textos que la componen y que explicita del siguiente modo: "En una palabra, los pobres clásicos son, quizá, lo peor tratados de toda la galería de autores"(Weimberg, 1957: 119), y esto a propósito de cómo, hasta la fecha, se habían ido traduciendo obras clásicas de unos idiomas a otros sin tener en cuenta el original o con estudios no coincidentes, textos incompletos y una suerte diversa de inexactitudes que descuidaban el rigor científico. En contraposición, la colección que dirige Ayala evidencia "una preocupación muy seria y un respeto encomiable por los quehaceres de la inteligencia", además de destacar "el valor de los títulos aparecidos hasta la fecha" (ibid.: 120). Posteriormente Weimberg centra su comentario sobre el Discurso del método, el Fausto, Los Lusíadas, El príncipe de Maquiavelo, las Lecciones sobre la filosofía de la historia universal de Hegel y las Obras completas de Shakespeare, destacando en cada una de estas obras tanto el valor de las traducciones elegidas, las más conocidas o eruditas hasta la fecha, como el de la calidad de los prólogos incorporados en cada una de estas ediciones. En definitiva, los libros que integran la colección de la Biblioteca de Cultura Básica son un hito en ese momento por su rigor científico. Destaca, por ejemplo, la traducción de la obra completa de Edgar Allan Poe encargada por Francisco Ayala a Julio Cortázar. En lo que refiere a obras fundamentales de Grecia y Roma, se publica La Ilíada de Homero y Las leyes de Cicerón. Ninguna de las dos obras está reseñada por Weimberg, pero curiosamente sí se las cita en la entrevista que el puertorriqueño Armindo Núñez realizó a Francisco Ayala sobre su estancia en Puerto Rico en 2008:

Uno de los elementos más significativos de su obra en Puerto Rico no meramente es la fundación y la marca de identidad de La Editorial, sino la importancia de los textos traducidos y la selección de traductores conocedores de su oficio tales como: Ildefonso Gil López (Las Lusíadas), Risieri Frondizi (El discurso del método), Luis Arocena (El príncipe), Luis Astrana (obras de Shakespeare), Roger Labrousse (Las Leyes), Luis Segalá Estalella (La Ilíada) y Antonio Espina (obras de Voltaire). (Núñez, 2008: 179) ${ }^{24}$.

\footnotetext{
${ }^{22}$ Precisamente son unos versos de Fausto de Goethe los que inician cada uno de los números de La Torre, con la siguiente traducción de Juan Ramón Jiménez: "Nací para ver, / mi sino es mirar; / jurado a mi torre, / el mundo me gusta. / Lo lejano miro, / miro lo cercano, / la luna y la estrella, / la selva y el corzo."

${ }^{23}$ Gregorio Weimberg (1919-2006) humanista y profesor de la Universidad de Buenos Aires, fue también director de la Biblioteca Nacional y director del Consejo Nacional de Investigaciones Científicas y Técnicas. Durante la dictadura sufrió asimismo la marginación, pero posteriormente reincorporado a la Universidad y reconocido con distintos honores, premios y distinciones.

${ }^{24}$ Y añade: "Esa primera colección de la que hablábamos, la Biblioteca de Cultura Básica, que todavía se sigue utilizando en muchos cursos universitarios ¿usted la concibió a raíz de unas conversaciones con don Jaime o usted traía ya la idea? No, todo fue surgiendo sobre la marcha creándose de un modo activo, espontáneo, personal, pero no como si fuera algo que lleva uno y lo saca en el momento para aplicarlo, sino que se iba
} 
A la intervención del periodista el intelectual granadino responde con un escueto "Sí". A continuación exponemos un análisis de la selección de la traducción y el estudio preliminar de que consta cada una de las dos obras incluidas en el catálogo de la colección. Actualmente ambas obras forman parte de los fondos de la Fundación Francisco Ayala en Granada (España), en un conjunto de diez que ha podido recuperar la institución ${ }^{25}$.

\section{La Ilíada de Homero por Guillermo Thiele y Luis Segalá}

La Ilíada de la Biblioteca de Cultura Básica consta de la conocida y prestigiosa traducción de Segalá, de 1908, que constituyó, junto con el resto de la obra de Homero, una de las cuatro partes de uno de los grandes hitos del homerismo en lengua española y que forma parte de las Obras completas de Homero publicadas en $1927^{26}$. El que fuera Catedrático de Griego de la Universidad de Barcelona desde 1906, Luis Segalá y Estalella (1873-1938) y que moriría en la Guerra Civil española en uno de los frecuentes bombardeos que sufrió la ciudad catalana, realizó una traducción de la obra de Homero caracterizada por una fidelidad absoluta al texto, de tal modo que hasta los años 80 se dice que Homero 'habló por boca de Segalá'. Carles Miralles en la semblanza que dedica al profesor de la Universidad de Barcelona señala la paradoja final de un Segalá olvidado después de su muerte, al tiempo que sus traducciones homéricas no cesaban de ser reeditadas incesantemente (Miralles, 2002: 13).

Antes de la fecha de 1956, año en que se publica esta Ilíada de la Biblioteca de Cultura Básica de la Universidad de Puerto Rico, al otro lado del Atlántico se publican las siguientes ediciones de las obras de Homero: la Odisea, también versión directa y literal del griego de Luis Segalá (Buenos Aires, Espasa-Calpe, 1951), y la conocida traducción de Alfonso Reyes de los IX primeros cantos de la Ilíada (México-Buenos Aires, Fondo de Cultura Económica, 1951). En la reseña de Jorge Páramo Pomareda (1954: 404) constatamos las siguientes publicaciones hispanoamericanas de tema

formando con la práctica. En esos años se crea la Facultad de Estudios Generales donde se ofrecen esos cursos de cultura básica para los estudiantes de primer año y simultáneamente usted labora en los comienzos de la misma. Con esa colección se están creando justamente los textos para los cursos que allí se ofrecen. Era la idea de Jaime Benítez a la que yo me sumé y cooperé con la mejor disposición de ánimo, así que fue un resultado del fruto de una colaboración intelectual amistosa" (Núñez, 2008: 173).

${ }^{25}$ Citamos a continuación el conjunto de obras que hasta 1957 se publicaron con el fin de contrastar la importancia de las dos obras del legado grecorromano en este corpus. Seguimos el estudio de Manuel Gómez Ros (2011: 259-260): “Goethe, Johann Wolfgang von, Fausto. Traducción de José Roviralta Borrell. Estudio de William Sinz. [Sin fecha; fue el primer volumen de la colección]; Hegel, Georg Wilhelm Friedrich, Lecciones sobre la filosofía de la historia universal, 1953. Traducción de José Gaos. Estudio preliminar de Adolfo G. Carpio; Descartes, René, El discurso del método, 1954. Traducción, estudio preliminar y notas de Risieri Frondizi; Camoens, Luís, Los Lusiadas, 1955. Traducción, prólogo y notas de Idelfonso Manuel Gil; Maquiavelo, Nicolás, El príncipe, 1955. Traducción de Luis Navarro. Edición, notas y apéndices de Luis A. Arocena; Shakespeare, William. Obras completas I. Macbeth, Trabajos de amor perdidos, Mucho ruido para nada, 1955. Edición y traducción de Luis Astrana Marín; Vega, Lope de, La Dorotea, 1955. Edición, prólogo y notas de José Manuel Blecua; Cicerón, Las leyes, 1956. Traducción, introducción y notas de Roger Labrousse; Homero, La Ilíada, 1956. Traducción de Luis Segalá."

${ }^{26}$ Con el subtítulo Versión directa y literal del griego por Luis Segalá y Estalella, edición adornada con ilustraciones arqueológicas de carácter homérico, Barcelona, Montaner y Simón editores, 1927. 
homérico anteriores a la de Alfonso Reyes, donde indica la ya existente edición de Segalá, que circulaba como 'pirata':

la Ilíada de Guillermo Jünemann (Concepción, Chile, 1902) y del Padre A. Lapalma (Buenos aires, s.f.), los fragmentos de la Ilíada y la Odisea traducidos por Leopoldo Lugones, la edición 'pirata' de un mal arreglo de la versión de Segalá y Estalella, debido a la Universidad Nacional de México (Ilíada, 2 vols.; Odisea, 1 vol., 192127), dos reimpresiones de la misma traducciones, una con introducción de Pedro Henríquez Ureña (Buenos Aires, 1943) y otra con estudio preliminar de Juan David García Bacca (Buenos Aires, Clásicos Jackson, 1943) y las Obras de Homero, comprendidos los Himnos (Pasto, 1938-9), traducidas por el colombiano Leopoldo López Álvarez.

El texto homérico está acompañado de una "Introducción" e "Índices" de Guillermo Thiele, profesor de la Universidad de Buenos Aires. La entidad del texto que sirve de introducción a la traducción de Segalá, será publicado en Caracas (1969) con el título Homero y su Ilíada, distinguido por el añadido de un único punto que lleva por título "La funesta mênis" (Thiele, 1969: 45-64). No obstante, no hay ninguna referencia a la edición previa de Puerto Rico. Como contraportada, leemos en la edición de 1969 el siguiente texto que destaca la importancia de su estudio:

Con su hondura y perspicacia habituales, el profesor Guillermo Thiele ha escrito una obra de síntesis, a la vez erudita y amena, que puede ser considerada, junto a los memorables trabajos de Alfonso Reyes, como la contribución más efectiva y perdurable hecha hasta hoy en nuestro idioma al estudio de la epopeya griega y de su más eximio representante. Se trata -como él mismo lo explica- de 'una breve excursión a través de ese laberinto que suele llamarse la cuestión homérica'.

En cuanto a los índices incluidos por Thiele, "Índices de nombres y de materias" (1956: 447-594), destacamos el rigor de la revisión a partir de los términos utilizados por Segalá. Con absoluto respeto a la edición del filólogo catalán, Thiele escribe (1956: 449-450):

Este índice reúne todos los nombres propios que se encuentran en la presente versión de la Ilíada, y en la forma en que Segalá y Estalella les dio. Les agrega algunos términos que el traductor vertió al castellano, mientras que la bibliografía internacional reciente suele referirse a ellos con la respectiva voz griega (p. ej.: Keres, véase Parcas; Litai, véanse Súplicas). Allí donde la versión deja lugar a dudas, el índice trata de desvanecerlas. [...] El índice pretende ser exhaustivo. Es decir, enumera, por regla, todos los pasajes en que aparece un nombre [...]. El índice está elaborado sobre la base del original griego. Como es imposible señalar, verso por verso, lo que le corresponde en el texto de Segalá y Estalella, el lector deberá guiarse por la numeración global al margen ${ }^{28}$.

\footnotetext{
${ }^{27}$ Páramo remite a la edición de 1927 de Segalá en la nota 2 de la reseña. Dice Segalá (1927: LXIV-LXV): "Algo escamados al ver que no se trataba de una nueva traducción, procuramos leer las dos páginas de dicha obra que se reproducían en reducido tamaño, y cuál no sería nuestro asombro al descubrir que la traducción publicada era una segunda edición de la nuestra, sin estampar en ella el nombre del traductor."

${ }^{28}$ Comprobamos de este modo cómo cumple la edición de esta Ilíada con las virtudes realzadas por Weimberg en su reseña sobre el conjunto de la colección dirigida por Francisco Ayala: -[ ] esta ejemplar empresa que es la -Biblioteca de Cultura Básica- patrocinada por la Universidad de Puerto Rico, además de los valores intrínsecos de sus publicaciones deberá servir de ejemplo para que en el futuro se abandone la poltronería intelectual, y se ponga cuidado en la selección de los textos, los que deberán estar acompañados, siempre, de estudios preliminares modernos, notas oportunas, ilustraciones adecuadas, índices completos, etc.- (Weimberg, 1957: 125).
} 


\section{Las leyes de Cicerón por Roger Labrousse}

La publicación de Las leyes de Cicerón en esta colección no es una casualidad. El interés del intelectual granadino por la obra del romano procede de al menos una década anterior a esta publicación de 1956, coincidiendo ya con su época de exilio. Así en Historia de la libertad (1943), texto ampliado posteriormente en "Ensayo sobre la libertad" (1944), leemos:

De esta nuevas corrientes de pensamiento, desarrolladas sobre todo en el campo de la antigua
cultura griega, representa en Roma un brote magnífico y precoz Cicerón -pensador muerto 43
años antes del nacimiento de Cristo-, que, en su escrito De las Leyes, se opone ya con vigorosos
argumentos a la vieja doctrina aristotélica de la desigualdad natural entre los hombres,
defendiendo la tesis de la igualdad de todos los humanos, fundado en la comunidad de la
naturaleza racional, de donde emana el derecho. Un siglo más tarde, Séneca, formado en la
filosofía estoica, proclama la igual capacidad de todos los hombres para la virtud, equiparando
de esta manera a libres y esclavos. (Ayala, 2006: 37).

Después de trece años, este interés ya manifiesto por la obra de Cicerón se materializa con la edición de Roger Labrousse que habría de servir para los estudios de la Universidad puertorriquense. Sobre la relación de Ayala con Labrousse, en Realidad (I, 4, 1947, 131-132) se reseña su libro En torno a la Teodicea (Edit. Facultad de Filosofía y Letras, Tucumán, 1946). Labrousse (1909-1956) es un intelectual de origen francés autoexiliado en 1939 con motivo del estallido de la Segunda Guerra Mundial. De México marcha a Argentina, instalándose en la Universidad de Tucumán como profesor en 1943. Allí se rodeará de un nutrido grupo de intelectuales, argentinos y otros igualmente exiliados de Europa por los conflictos bélicos, tales como Manuel García Morente, Rodolfo Mondolfo, Benvenuto Terracini, Elsa Tabernig o Jackques Rush. Catedrático de latín y literatura francesa, en palabras de Judith Casali de Babot, Labrousse fue "un erudito y sutil latinista, un profundo conocedor de la cultura clásica. La permanencia de su obra nos permite contar hoy con la impecable introducción, traducción e interpretación de Las leyes de Cicerón" (Casali, 2006: 116) ${ }^{29}$. Víctima a su vez de las nuevas injusticias totalitarias que sufrirá Argentina, será expulsado de su cátedra en 1953. Su restitución en 1956 llegará tarde, pues es el año en que muere, coincidiendo con la publicación en la colección Biblioteca de Cultura Básica de la Universidad de Puerto Rico, obra que sigue utilizándose como bibliografía en los planes de estudio de esta universidad.

La edición de Las leyes de Cicerón, junto con la de Álvaro D’Ors (1953) es una apuesta por dar a conocer esta obra del orador romano hasta entonces poco conocida

\footnotetext{
${ }^{29} \mathrm{O}$ también: “Estas reflexiones tomadas del pensador ruso - compartidas por Labrousse, no quedaron en meros análisis especulativos, las hizo parte de su vida, las volcó como docente, como investigador, como amigo, a través de su compromiso con la Universidad Nacional de Tucumán. De aquí su asombro e incomprensión y sus reiteradas notas solicitando una explicación cuando es dejado cesante en 1953, por iniciativa de Carlos Aguilar, golpe fatal para un hombre de su dedicación. Aunque continuara con sus Cursos en su casa y en el Círculo de la Prensa, esta medida privó a nuestra Universidad de una personalidad excepcional. Su reincorporación - mejor dicho la Resolución por la que se disponía su reintegración en Sociología, Cátedra que ni siquiera era la suya debido a la única partida existente-, llegó demasiado tarde e, irónicamente, de la mano de un gobierno militar que derribaba a un régimen constitucional, el de Perón, pero desnaturalizado por el autoritarismo y la arbitrariedad" (Casali, 2006: 123).
} 
fuera del ámbito jurídico. Ambos traductores, Labrousse y D’Ors, puntualizarán tal circunstancia en sus respectivas introducciones, señalando D'Ors que "el De legibus es una piedra fundamental dentro de la arquitectura de nuestra historia de Occidente" (1953: 9). Por su parte, Labrousse escribe que "El tratado de Las leyes (De legibus), de Marco Tulio Cicerón, es una obra importante y, sin embargo, mal conocida dentro de la literatura clásica latina", subrayando además que "de todos los trabajos doctrinales de Cicerón quizá sea éste el que permita apreciar mejor la flexibilidad y a veces la gracia del talento de su autor" (Labrousse, 1956: IX).

De la extensa introducción de la edición de Labrousse, muy destacables son las pinceladas que nos traslada sobre la figura de Cicerón, mostrándolo cercano y familiar en una comparación con el hombre contemporáneo, como ocurre con el retrato que nos hace de "El hombre Cicerón" (ibid.: XXIX-XXXII), del que destacamos el siguiente pasaje:

La vida de este hombre no fue la de un gran estadista, y tendremos que examinar la incidencia de sus limitaciones sobre su obra de pensador político. [...] Por otro lado, conviene interpretar con cierta prudencia las expresiones de los discursos y de los libros de Marco Tulio. Había dos registros en la vida romana, el privado y el público, y entre ellos la distancia era normalmente mucho mayor que en nuestra civilización. [...] Pensaban desde el comienzo y conservaban el hábito de pensar que el hombre que habla de toga no debe tener la sencillez y la familiaridad del hombre que abre su alma a un amigo. Tal vez el cristianismo, seguramente el romanticismo y la democracia moderna nos han sugerido otros usos: nos desnudamos por sinceridad y llamamos declamatorio a todo lo que parece indicar solemnidad en el estilo y en los sentimientos. Los romanos, que nos hubieran juzgado indecentes, consideraban, al contrario, que ciertas convenciones verbales eran imprescindibles para mantener la dignidad de la vida colectiva y preservar la herencia moral de los antepasados (mos maiorum). (Labrousse, 1956: XXIX-XXX).

Asimismo en esta introducción encontramos textos que dialogan entre el pasado clásico y el presente del traductor, como hemos comprobado en otros estudios incluidos en este trabajo. En este sentido, es particularmente destacable cuando, a propósito del libro I de Las leyes, Labrousse establece un diálogo entre el pensamiento de Cicerón y su contemporaneidad, donde la incorporación de otros textos del autor romano, en este caso procedentes de De finibus, deja abierto en el tiempo el campo de acción reivindicado para la humanitas:

Hemos recibido al nacer "una chispa de razón", pues "vemos en los niños como destellos de virtud, en los que debe encenderse la razón del filósofo para que ésta, como si anduviera bajo la conducta de un dios, alcance el fin último de la naturaleza" ${ }^{\prime 30}$. Pero sin el auxilio de una buena educación dejamos que se apague casi del todo. Por eso la sociedad general necesita el refuerzo de las sociedades particulares. No obstante, esto no significa que no ejerza influencia alguna en la vida del ciudadano. Al contrario, de la pertenencia a una misma especie deriva la virtud de humanitas, es decir, aquella que consiste en respetar a todo hombre por el solo hecho de que es nuestro semejante. (ibid.: LIX).

\footnotetext{
${ }^{30}$ Referencia en nota 52 a Fin V, 43.
} 


\section{CONCLUSIÓN}

Hemos expuesto en este trabajo la relación de Francisco Ayala con un grupo importante de intelectuales que publicaron en las revistas que dirigió en su exilio, primero junto con Lorenzo Luzuriaga en Realidad y luego en La Torre con Jaime Benítez como director. Traductores, helenistas y latinistas, dejaron en estos lugares documentos fundamentales de análisis y estudio de la Antigüedad para la civilización contemporánea. Junto con ello, tanto la selección de las obras como algunas cuestiones de análisis expuestas, revelan el interés por el humanismo de origen clásico. Desde la Paideía de Jaeger traducida por Wenceslao Roces, a Las leyes de Cicerón traducida y prologada por Roger Labrousse, hemos recorrido un itinerario que va del bienio 19471948 con Realidad, a los años 1953-1956 con La Torre, en el que la figura de Francisco Ayala permite que estos textos se difundan a través de su publicación en dos de las revistas más importantes en lengua española de ese momento ${ }^{31}$.

Entre las reseñas y artículos de Realidad se intercalan dos documentos sobre el humanismo, el conocido texto de Martin Heidegger y el de Karl Kerényi, evidenciándose un claro interés por su publicación paralela y contrastada. El texto de Kerényi, como filólogo de lenguas clásicas, incide en aspectos del humanismo en la Antigüedad, así como en el papel que debe desempeñar el filólogo contemporáneo ante un humanismo que no debe reducirse al estudio histórico. Detrás de ello, está el ejercicio del compromiso activo del hombre y no sólo el estudio del ser, ni siquiera como pudo promoverse en las antiguas Grecia y Roma.

En este contexto no sólo encaja la publicación de una nueva Ilíada de Homero como libro fundacional de la literatura occidental, sino también Las leyes de Cicerón. Una de las claves está en la referencia a la humanitas ciceroniana. Baste retomar una de las citas de otro de los textos de Cicerón que utiliza Labrousse, en concreto procedente de Los deberes (Labrousse 1956: LX): “Debemos asignarnos una sola meta: identificar el interés de cada uno con el de todos los demás" (Off.3.26-28). Esta frase de Cicerón parece resonar en todos los escritos aquí expuestos, en la selección de los textos, así como en las vidas exiliadas que pusieron en marcha toda una maquinaria de conocimiento y de estudio. La Antigüedad ya no es sólo un conocimiento heredado a través de diversos estratos de la historia y sus necesarias adaptaciones. La Antigüedad es recuperada en vivo y directo diálogo con el presente, como esencia que descubre el ser occidental exiliado dentro de sí -tal y como nos lo ha expuesto Schajowicz-, y que se suma al compromiso intelectual que hace de todos los autores aquí reseñados auténticos humanistas para la

\footnotetext{
${ }^{31}$ Para destacar la importancia de ambas revistas, con respecto a Realidad nos dice L. García Montero (2007: XXIX): “Realidad, publicada entre enero de 1947 y diciembre de 1949, fue una de las revistas más importantes de la cultura hispánica en su época. Sus responsables pudieron sentirse orgullosos en más de una ocasión de haber protagonizado un esfuerzo de alta calidad, con colaboraciones oportunas y muy significativas. Convocaron a lo mejor de la cultura de su tiempo para intentar comprender, diagnosticar y pensar en un mundo en crisis"; o, con respecto a La Torre, $\mathrm{M}^{\mathrm{a}} \mathrm{J}$. Sánchez Montes (2006: 97): "Durante los años que estuvo al cuidado de Francisco Ayala La Torre fue la mejor revista de su género en lengua española."
} 
segunda mitad del siglo XX. El concepto romano humanitas está presente en quienes, como Francisco Ayala, forjaron un espacio ensayístico y divulgativo al servicio de los mejores intelectuales e investigadores del momento. Intelectuales víctimas de una época totalitaria y bélica, pero conscientes de su labor pedagógica y cultural aliviada de servidumbres en el continente americano.

\section{BIBLIOGRAFÍA}

Ayala F. (1988): Recuerdos y olvidos, Madrid, Alianza.

Ayala, F. ([1943] 2006): Historia de la libertad, edición facsímil, Granada, Ayuntamiento de Granada [Buenos Aires, Atlántida].

Ayala, F. ([1992] 2006): El tiempo y yo, o el mundo a la espalda, Madrid, Comunidad de Madrid, Consejería de Educación-Visor libros.

Ayala, F. (2007): Obras Completas III. Estudios literarios, edición de Carolyn Richmond, Barcelona, Círculo de Lectores-Galaxia Gutemberg.

Casali, J., Jorrat, J., Lupiáñez, G. (2006): “Roger Labrousse: sus aportes historiográficos en el campo de la filosofía política”, en AA. DD. (2006), Actas del Primer Congreso sobre la Historia de la Universidad de Tucumán, Tucumán, Secretaría General de la UNT: 115-125.

Chicharro, A. (2006): El pensamiento vivo de Francisco Ayala, col. Alminares, Granada, Dauro.

Díaz Díaz, G. y Santos-Escudero, C. (1982): Bibliografía filosófica hispánica (1901-1970), Madrid, CSIC.

Eliade, M. (1954): “Los mitos en el mundo moderno”, La Torre, 6, 69-86.

Emiliozzi, I. (ed.) (2012): Francisco Ayala en La Nación de Buenos Aires, Valencia, PreTextos.

García Jurado, F. (2008): "Prólogo", en I. López Calahorro (2008) Francisco Ayala y el mundo clásico, Granada, Universidad de Granada: 17-24.

García Montero, L. (2007): “La aventura de pensar el mundo", introducción al facsímil de la revista Realidad, I, col. Facsímiles de Revistas Literarias, Sevilla, Renacimiento, XXIX-LXXV.

García Montero, L. (2009): Francisco Ayala. El escritor en su siglo, col. Los libros de la Estrella, Granada, Diputación de Granada.

Gómez Ros, M. (2011): “Francisco Ayala, editor”, en L. García Montero y M. Rodríguez Gutiérrez (eds.) (2011), De este mundo y los otros. Estudios sobre Francisco Ayala, Madrid, Visor Libros: 249-261.

Heidegger, M. ([1948] 2007: “Carta sobre el humanismo”, Realidad, vol. III, 7 y 9, 10911115 [1-25] y 1467-1491 [343-367].

Jaeger, W. ([1957] 1962): Paideía, México, Fondo de Cultura Económica. 
Jiménez Delgado, J. (1958): “Supervivencia de Cicerón,”, Helmántica, vol. 9, 30, 351-362. Kerényi, K. ([1948] 2007): "El humanista en la encrucijada”, Realidad, vol. III, 8, 12531263 [147-157].

López Calahorro, I. (2008): Francisco Ayala y el mundo clásico, Granada, Editorial Universidad de Granada.

López Calahorro, I. (2010): “La transformación del mito de Medusa en Francisco Ayala. De Ovidio a Lucano", en J. Luque, Ma Dolores Rincón e I. Velázquez (eds.) (2010), Dulces Camenae. Poética y poesía latinas, Jaén-Granada, Sociedad de Estudios Latinos.

Luzuriaga, L. ([1947] 2007): “Werner Jaeger, Paideía. Los ideales de la cultura griega. Fondo de Cultura Económica, México, 3 vol., 1942-1945”, Realidad, vol. I, 2, 347-349 [307-309].

Menéndez Pelayo, M. (1953): “Apuntes sobre el ciceronianismo en España y sobre la influencia de Cicerón en la prosa latina de los humanistas españoles", en Biblioteca Hispano-Latina Clásica: III, 177-271.

Miralles, C. (2002): Lluis Segalá. Semblança biográfica, Barcelona, Institut d'Estudis Catalans.

Mommsen, T. ([1945] 2006): El mundo de los Césares, traducción y prólogo de Wenceslao Roces, col. Conmemorativa 70 Aniversario, México, Fondo de Cultura Económica.

Mondolfo, R. ([1947] 2007): “Benjamín Farrington, Ciencia griega de Tales a Aristóteles. Colección Pingüino, edit. Lautaro, Buenos Aires, 1947", Realidad, vol. II, 6, 10291031 [431-433].

Mondolfo, R. (1954): “Séneca y la infinitud del progreso espiritual”, La Torre, 5, 63-74.

Mora, A. (2000): “La paideía republicana de Joaquín Xirau”, prólogo en R. Xirau (2000) Obras completas de Joaquín Xirau. Tomo III, vol. 2: Escritos sobre historia de la Filosofía, Madrid, Fundación Caja Madrid, Anthropos editorial.

Navajas, G. (2006): “La escritura de la libertad y la cultura industrial en Francisco Ayala", Hispania, vol. 89, 4, 702-717.

Núñez, A. (2008): “Esto de recordar a los 101 años”, La Torre, 48, 169-181.

Oviedo, G. (2006): "Rodolfo Mondolfo. Humanista de izquierda", Cuyo. Anuario de Filosofía argentina y americana, 23, 155-192.

Páramo, J. (1954): “La Ilíada de Homero. Traslado de Alfonso Reyes. Primera parte: Aquiles agraviado. México, Fondo de Cultura Económica, 1951. 243 págs.”, Thesaurus (Boletín del Instituto Caro y Cuervo), Tomo X, 404-408.

Pró, D. (1967): Rodolfo Mondolfo, 2 vol. Buenos Aires, Losada.

Rivaya, B. (2000): “Comunismo y compromiso intelectual: Wenceslao Roces" (con presentación a cargo de José María Laso), Papeles de la FIM, 14, 145-187, y 15, 160-165. 
Rojas Osorio, C. (2005): “La filosofía en Puerto Rico: los transterrados”, Revista Filosofía Universidad Costa Rica, XLIII, 108, 57-62.

Romero, F. (dir.) ([1947-1949] 2007): Realidad. Revista de ideas (Buenos Aires, 1947-1949), prólogo de L. García Montero, colección completa (18 números), col. Facsímiles de Revistas Literarias, Sevilla, Renacimiento.

Romero, J. L. ([1947] 2007): “Teodoro Mommsen, El mundo de los Césares. Ed. 'Fondo de Cultura Económica', México, 1945”, Realidad, vol. I, 1, 165-166 [147-148].

Romero, J. L. ([1948] 2007): “Ludwig Friedländer, La sociedad romana; Historia de las costumbres en Roma, desde Augusto hasta los Antoninos, Fondo de Cultura Económica, 1947", vol. III, 8, 1948, 1376-1378 [270-272].

Romero, M. (2005): “Traducciones y ediciones de la obra de Mommsen en España (1876-1905)", en J. Martínez-Pinna (coord.) (2005) En el centenario de Theodor Mommsen (1017-1903): homenaje desde la Universidad española, Málaga, UMA, Servicio de Publicaciones: 135-152.

Sánchez Guevara, O. (2011): “Ludwig Schajowicz, a un siglo de su nacimiento" (consultado en julio de 2012).

Sánchez Montes, M. J. (2006): “Ayala en Puerto Rico, Puerto Rico en Ayala”, en A. Sánchez Trigueros y M. A. Vázquez Medel (2006) Francisco Ayala y América, Sevilla, Alfar: 89-100.

Schajowicz, L. (1953): “La forma de la literatura europea”, La Torre, 1, 95-111.

Schajowicz, L. (1954): “Orfeo y Anfión”, La Torre, 5, 63-74.

Schajowicz, L. ([1962] 1990): Mito y existencia, Puerto Rico, Universidad de Puerto Rico.

Quiñónez, B. A. y Ale, M. C. (2009): “Los estudios clásicos en Tucumán”, Circe clás. mod. 13, 189-198 (consultado en julio de 2012).

Roces, W.: “Bibliografía traducida por Wenceslao Roces", Asociación Cultural Wenceslao Roces (consultado en julio de 2012).

Weimberg, G. (1957): “Biblioteca de Cultura básica”, La Biblioteca (Revista de la Biblioteca Nacional), Tomo IX, 1, Buenos Aires, 119-125.

Xirau, R. (1986): “Joaquín Xirau (1895-1946). Un esbozo” (consultado en julio de 2012).

\section{Ediciones de la Ilíada y la Odisea de Homero consultadas}

Homero (1951): La Ilíada. Primera parte: Aquiles agraviado, traslado de A. Reyes, México, Fondo de Cultura Económica.

Homero ([1951] 1998): Odisea, traducción de L. Segalá, introducción de A. López Eire, Madrid, Espasa Calpe.

Homero (1956): La Ilíada, traducción de L. Segalá, introducción e índices de Guillermo Thiele, Madrid, Ediciones de la Universidad de Puerto Rico, Revista de Occidente.

Homero (2010): Ilíada, prólogo, traducción y notas de O. Martínez García, Madrid, Alianza. 


\section{Ediciones de Las leyes de Marco Tulio Cicerón ${ }^{32}$ consultadas}

Cicerón, M. T. (1924): Obras completas de Cicerón. Tomo VI. Tratado de la República, Tratado de Las leyes, versión castellana de Francisco Navarro, Madrid, Biblioteca Clásica.

Cicerón, M. T. ([1953] 1970): Las leyes, traducción, introducción y notas por Álvaro D’Ors, Madrid, Instituto de Estudios Políticos.

Cicerón (1989): La República y Las leyes, edición de J. Mª Núñez González, Madrid, Akal. Cicerón (1956): Las leyes, edición bilingüe, introducción, traducción y notas de R. Labrousse, Madrid, Ediciones de la Universidad de Puerto Rico, Revista de Occidente.

Cicerón (1989): Las leyes, introducción, traducción y notas de R. Labrousse, Madrid, Alianza.

Cicerón, M. T. (2009): Las leyes, traducción, introducción y notas de Carmen Teresa Pabón, Madrid, Gredos.

${ }^{32}$ Sobre las iniciales del orador romano, “M. T" (Marco Tulio), las anotamos en los casos en que los autores de las ediciones las han hecho constar. 



\title{
SOBRE LA ESTRUCTURA DISCURSIVA DEL TEXTO POÉTICO: LA LENGUA VISUAL DE HUIDOBRO EN EL ESPEJO DE AGUA
}

\author{
FRANCISCO JIMÉNEZ CALDERÓN ${ }^{1}$
}

Universidad de Extremadura

\section{Resumen}

El presente trabajo analiza la estructura discursiva de los textos de El espejo de agua, de Vicente Huidobro, considerando los valores visuales de los versos y palabras que conforman sus poemas. Para ello, se conciben dichos valores como parte del ritmo del poema, como factores que influyen fuertemente en su recepción final, y se relacionan con impresiones visuales derivadas del aparato metafórico y del significado del texto. La conclusión es que la distribución espacial de los elementos resulta clave en la estructura interna y en el significado del poema, y afecta del mismo modo al poemario en su conjunto: en el Espejo de agua, la recepción visual, más sutil que en otras obras del autor, resulta clave para una interpretación integral.

Palabras clave: estructura discursiva, texto literario, género poético, uso literario de la lengua, El espejo de agua

\section{Abstract}

This paper analyzes the discursive structure of the texts of El espejo de agua, by Vicente Huidobro, considering visual values of the verses and words in his poems. For this, these values are conceived as part of the rhythm of the poem, as factors that strongly influence their final perception, and they are related to visual impressions which the metaphorical meaning of the text produces. The conclusion is that the distribution of the elements is crucial for the internal structure and meaning of the poem, and it affects the work as a whole: in El espejo de agua, visual reception, which is more subtle than it is in other works of the author, is essential to a comprehensive interpretation.

Key words: discursive structure, literary text, poetic genre, literary use of language, El espejo de agua

\footnotetext{
1. Correo-e: fjimcal@unex.es. Recibido: 10-10-2012. Aceptado: 09-03-2013.
} 


\section{INTRODUCCIÓN}

Entre sus numerosos rasgos, el discurso literario presenta una serie de peculiaridades que afectan a la caracterización de varios de sus géneros². Piénsese, por ejemplo, en la dificultad que tradicionalmente ha implicado la definición del teatro, en el que, paradójicamente, conviven la existencia y permanencia de un texto escrito y la composición de ese texto pensada para la escena ${ }^{3}$. En una línea similar puede situarse el guión cinematográfico, cuya publicación es, además, mucho menos frecuente, debido al carácter permanente de la película en que desemboca; existen casos, no obstante, en los que el guion (también el texto teatral) proporciona informaciones que no se manifiestan en el filme ${ }^{4}$, con lo que nos encontramos, de nuevo, con dos planos del mismo fenómeno: en ambos casos, cine y teatro, los textos escritos pueden considerarse géneros literarios (o géneros discursivos, al menos) que conviven con las representaciones en que fructifican; el análisis de cada uno de los planos o de ambos en conjunto responde, por descontado, a enfoques diferentes. Considérese, por último, el género poético, al que, al cabo, se refieren las presentes líneas. El poema se concibe también desde dos perspectivas, en tanto que puede recibirse por vía del recitado o por vía de la lectura. Así, el poeta, amparado en la variabilidad de la métrica y teniendo en cuenta ambos canales, puede ahondar en el hallazgo de efectos sonoros pero también visuales.

Se produce, así, una asociación entre poesía e imagen que se revela como un ámbito amplísimo, tanto desde el punto de vista creativo como desde la perspectiva del investigador. La presencia dela imagen en la poesía está representada, sin ir más lejos, por la metáfora, que acude a una figura visual para representar un concepto u otra realidad diferente ${ }^{5}$. Pero existen posibilidades más directas como el caligrama, que constituye una representación visual por medio de recursos tipográficos; el procedimiento hunde sus raíces en la antigüedad ${ }^{6}$, pero recibió un gran impulso a partir del Renacimiento

\footnotetext{
${ }^{2}$ Utilizamos el término discurso para referirnos al producto textual (discursivo) originado en un ámbito (discursivo también) concreto. El enfoque en el que se ampara esta clasificación textual es, en efecto, el del análisis del discurso. Los subtipos de textos, según dicha perspectiva, constituyen géneros discursivos, que presentan ciertas diferencias pero comparten el mismo ámbito. Como introducción al asunto, vid., por ejemplo, Calsamiglia y Tusón (1999) o, más en relación con el análisis de géneros, Bajtín (1982).

${ }^{3}$ En torno a ello, vid. las certeras consideraciones de Trancón (2006), sobre todo en el capítulo "Componentes básicos del teatro" (p. 153) y, especialmente, en el apartado "El texto teatral" (p. 162).

${ }^{4}$ Tenemos en preparación un artículo sobre la película The Hustler (Robert Rossen, 1961) que muestra cómo una referencia en las acotaciones del guion proporciona interpretaciones del filme a las que habría sido muy difícil llegar únicamente a través del visionado.

${ }^{5}$ La metáfora no es exclusiva de la literatura, sino que está presente en todas las variedades y registros lingüísticos. Tómese, como ejemplo, el discurso científico (Galán Rodríguez, 2001).

${ }^{6}$ El referente clásico son los technopaignia griegos y los carmina figurata, en los que se forman figuras mediante los versos escritos. La palabra y la imagen, no obstante, se asocian también en civilizaciones anteriores como la egipcia (Cózar, 1991).

Por otro lado, un punto de referencia al respecto de las relaciones entre poesía e imagen es el conocido tópico horaciano "Ut pictura poesis", que establece una serie de correspondencias entre la poesía y la pintura. Sobre dicho tópico y su desarrollo en las relaciones entre la literatura y otras artes puede consultarse el trabajo de Corbacho Cortés (1999), autora también de un monográfico en el que se analiza el recurso a la pintura en poemas de Manuel Machado (1999).
} 
y alcanzó pleno desarrollo en la etapa de las vanguardias de comienzos del siglo $\mathrm{XX}^{7}$. En este periodo, preocupa especialmente a los poetas la recepción visual del texto y la forma en que este se plasma en el papel; ahí encuentra su razón de ser, por ejemplo, el verso libre, que no está obligado a detenerse o prolongarse por razones de métrica -en el sentido estrictamente silábico- y permite muy diversos alardes formales. De hecho, el valor visual o tipográfico puede concebirse como parte del ritmo del poema, pues produce necesariamente efectos como la repetición o la elisión. Los movimientos de vanguardia, en su afán de ruptura, aprovechan esta circunstancia y se valen de recursos como la 'intratipografía', que afecta a la división interna de la palabra, a la alternancia de grafías versales y minúsculas, a la mezcla de tipos y tamaños, etcétera, y propugnan la 'heterometría' o líneas quebradas. Todos estos recursos conforman un 'ritmo visual' que conlleva el rechazo vanguardista del estatismo y del recorrido horizontal de la mirada en la lectura, que provoca un 'movimiento' en el poema en el que la dispersión tipográfica se manifiesta como rasgo más perceptible ${ }^{8}$.

Teniendo en cuenta todo ello, el presente trabajo se aproxima a la obra de uno de los escritores más destacados en la recuperación vanguardista del vínculo entre literatura e imagen, el chileno Vicente Huidobro'. Si bien existen obras de Huidobro en las que el poeta profundiza radicalmente en el manejo los recursos visuales, el análisis que se propugna a continuación se detiene en un poemario relativamente mesurado, El espejo de agua. Aunque no de forma tan evidente como en trabajos posteriores, el poemario, según se muestra en las líneas siguientes, presenta una gran riqueza de elementos visuales que da consistencia al conjunto de los versos. Se pretende, en definitiva, precisar los contenidos textuales a través del estudio del mencionado ritmo visual, dado que la grafía, como código paralelo al del sonido, proporciona matices imperceptibles acústicamente. Así, pueden sistematizarse en el poemario los significados que portan, respectivamente, la largura y la cortedad de los versos, los distintos tipos de espacios en blanco y las representaciones icónicas a que da lugar la colocación de los versos, lo cual proporciona, asimismo, determinados significados para los poemas y para el texto en su conjunto.

\footnotetext{
${ }^{7}$ Los artistas de las vanguardias, en su afán de experimentación, no dudaron en misturar artes diferentes, y la literatura y la pintura se relacionaron con profusión. Sobre el particular, puede consultarse en trabajo de Monegal (1998). Acerca de las vanguardias, vid. Cirlot (1991), Ramírez (1991) y, para el ámbito latinoamericano, Schwart (1991).

${ }^{8}$ Hay estudiosos, no obstante, que no participan de esta idea, en tanto que otros han hablado de este 'ritmo visual'. El asunto está perfectamente sintetizado en los trabajos de López Martínez (1988, 1989). López analiza en sus artículos varios procedimientos que los poetas del 27 emplearon para dotar de carácter visual a sus versos, muchos de los cuales se documentan también en el presente estudio a propósito de El espejo de agua.

9 Sobre la obra de Huidobro -la bibliografía es extensísima-, vid. Caracciolo (1974) y Costa (1975), y también las aportaciones de Montes (1990). Acerca del Creacionismo, movimiento al que el poeta se adscribe, puede consultarse Aullón de Haro (2000) y Martín Ferrer (1999), si bien esa adscripción no ha estado exenta de polémica, sobre todo en relación con el fechado de, precisamente, El espejo de agua (Rutter, 1977; Rojas, 2004).
} 


\section{EL ESPEJO DE AGUA Y SU CONTEXTO}

Es este un poemario singular en la obra de Huidobro ${ }^{10}$. Se trata de un trabajo breve, pues consta tan sólo de nueve poemas, y se sitúa entre dos obras fundamentales para el poeta: Adán (1916), donde por primera vez se adhiere al versolibrismo, aunque antes ya había publicado poemas en prosa; y Horizon carré (1917), que supone el inicio de las obras francesas de Huidobro, imbuido ya en las vanguardias europeas ${ }^{11}$.

En el momento en que compone El espejo de agua, Huidobro se halla inmerso en tentativas de definición poética que irá plasmando en distintos manifiestos. En Adán desarrolla varias ideas acerca de cómo debe ser la nueva poesía, y el primer poema de El espejo de agua se refiere también a tales preceptos. Por lo que respecta a Horizon carré, Huidobro despliega un gran número de recursos visuales y se acerca al caligrama, como ya había hecho en "Japonerías de estío", título bajo el que se agrupan tres poemas visuales incluidos en Canciones en la noche (1913). El recurso al caligrama supone una declaración directa sobre el significado visual que ofrece el verso. Obsérvese el conocido poema "Paysage", de Horizon carré:

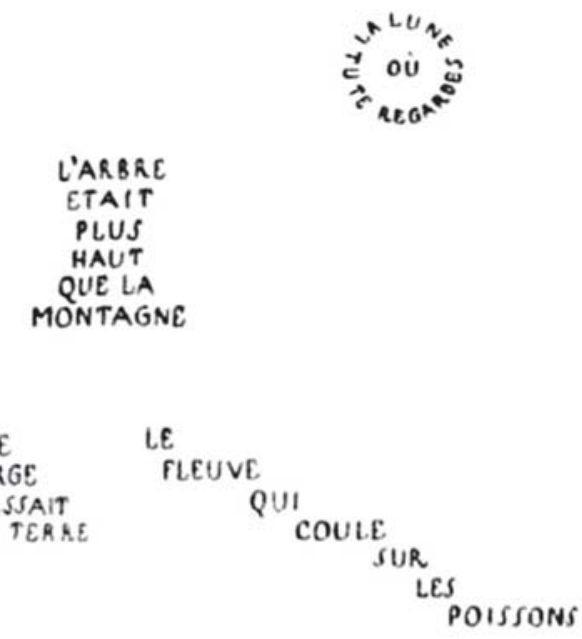

ATTENTION A NE PAS
JOUER SUR LHERBE
FRAICHEMENT PEINTE

UNE CHANSON CONDUIT LES BREBIS VERS LETABLE

\footnotetext{
${ }^{10}$ La edición utilizada para este estudio ha sido la de Montes (1976). Para consideraciones generales sobre el poemario, vid. Costa (1975: 249-266) y Yúdice (1978: 21 y ss.), y las precisiones de Rutter (1977) y Rojas (2004).

${ }^{11}$ Vid. n. 8.
} 
Como se ve, cada 'estrofa' representa la imagen de aquello a lo que alude: la luna, el árbol, la montaña, el río, la hierba y el rebaño. Pero el juego visual no se detiene ahí. La circunferencia que forma el verso que alude a la luna deja grandes espacios en blanco, lo que se relaciona con la luminosidad del satélite; la forma redonda, además, recuerda a un espejo, lo cual daría más sentido al verso: "La lune oú tute regarde". El árbol, al ser "plus aut que la montagne", se sitúa en un plano superior a ella; además, la palabra "arbre" corona la representación y la palabra "montagne" la sostiene. La montaña, al ser "si large qu'elle depassait les extremites de la terre", sobresale en el extremo izquierdo de la composición, y resulta, en efecto, más ancha que alta. En cuanto al río, su forma escalonada indica que "coule". Y, además de las propias formas, hay palabras en el poema que refuerzan su carácter visual. Es el caso de "regarde", que obliga, no a leer el poema, sino a mirarlo. Y también el adjetivo "peinte", que no sólo alude a "l'herbe", sino a todo lo que el lector contempla.

Así, este tipo de composiciones se concibe considerando las posibilidades espaciales de la página. En El espejo de agua no se encuentran textos puramente caligramáticos, con lo que el sentido de los textos está, en general, representado por unidades más definidas, menos dispersas gráficamente; de hecho, Horizon Carré incorpora variaciones de poemas de El espejo de agua que muestran el salto del desarrollo unitario del tema a la disgregación espacial del significado, que obliga a una lectura desplazada del texto y que potencia su mensaje ${ }^{12}$. No obstante, este poemario refleja la nueva noción de espacio manejada por Huidobro, pues en él "adquiere una importancia que lo erige en principio estructurador, del mismo modo que se juega con la tipografía y las nuevas propuestas del diseño"13.

\section{LOS POEMAS DE EL ESPEJO DE AGUA Y SUS VALORES VISUALES}

Analizamos por separado cada uno de los poemas que componen El espejo de agua en un apartado propio. Para facilitar el análisis, reproducimos los poemas al inicio de cada apartado. Antes de entrar en el comentario de los textos, realizamos unas breves consideraciones sobre el título del poemario.

\subsection{Título}

El mismo título de la obra resulta muy significativo desde el punto de vista que toma el presente trabajo. No se trata de una excepción en la obra de Huidobro ${ }^{14}$, pues muchos de sus poemarios y poemas toman nombres que aluden al concepto del espacio o de la imagen: “Los frescos ilusorios", de La gruta del silencio; "Era una visión”,

\footnotetext{
${ }^{12}$ Cf. Barón (2007). En su trabajo, Barón propone un atentísimo análisis de las variaciones de los textos en Horizon Carré. Nosotros nos centramos aquí en el paso previo a esas variaciones, en el aprovechamiento espacial y los recursos gráficos -menos osados y, por tanto, de menor alcance, aunque no exentos de sentido- que presentan los poemas en El espejo de agua.

${ }^{13}$ Pizarro (1993: 61).

${ }^{14} \mathrm{Ni}$ es, tampoco, una excepción en las obras de otros poetas vanguardistas; vid. trabajos citados en n. 6 .
} 
“Triángulo armónico", “Fresco nipón”, de Canciones en la noche; "La amada reflejándose en el agua", de Las pagodas ocultas; Horizon carré, y en él, "Paysage"; "Film", en Automne regulier; etcétera.

Por lo que respecta a El espejo de agua, el título supone una declaración de intenciones, pues Huidobro arremete, en sus concepciones poéticas, contra el tópico aristotélico de la mímesis de la realidad. El poeta no ha de representar la realidad, sino crearla, con lo cual la poesía no debe ser un "espejo" de la realidad, sino una realidad propia. El sintagma "el espejo de agua", por tanto, no pretende reflejar lo que el poeta ve, sino lo que el poeta crea ${ }^{15}$. Por otro lado, la idea de "espejo" invita directamente a mirar, no sólo a leer los poemas, pues "la poesía de Huidobro implica una estética de la superficie, de luminosos efectos, de súbitas percepciones [...]. La de Huidobro es, en cierta medida, una retina impresionista" ${ }^{16}$. El hecho, por último, y en relación con la singularidad creadora, de que el espejo sea "de agua" indica que no va a contemplarse una visión exacta del mundo, sino distorsionada, filtrada por la mano del poeta ${ }^{17}$.

\section{2 "Arte poética"}

Que el verso sea como una llave

Que abra mil puertas.

Una hoja cae; algo pasa volando;

Cuanto miren los ojos creado sea,

Y el alma del oyente quede temblando.

Inventa mundos nuevos y cuida tu palabra;

El adjetivo, cuando no da vida, mata.

Estamos en el ciclo de los nervios.

El músculo cuelga,

Como recuerdo, en los museos;

Mas no por eso tenemos menos fuerza:

El vigor verdadero

Reside en la cabeza.

Por qué cantáis la rosa, ¡oh Poetas!

Hacedla florecer en el poema;

Sólo para nosotros

Viven todas las cosas bajo el Sol.

El poeta es un pequeño Dios.

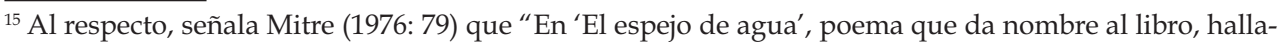
mos la imagen del espejo convertida en una realidad fluyente como el río: 'Mi espejo, corriente por las noches / Se hace arroyo y se aleja de mi cuarto'. Esta imagen funda una identidad (espejo-río) que hace posible, dentro de un marco de estricta lógica -poética, desde luego- otra imagen posterior". En efecto, se trata de 'identidades' más que 'evocaciones'.

${ }^{16}$ Mitre, 1976: 82-83.

${ }^{17} \mathrm{Al}$ respecto del poema "El espejo de agua", que da título al poemario, afirma Goic (1994: 718): "Poema metapoético, poema que habla de la poesía y de su factura creacionista, es decir, de su transformación del mundo en el proceso de hacerlo y de plasmarlo efectivamente distinto, mágico y exaltado".
} 
El poema que abre El espejo de agua se relaciona íntimamente con lo que exponíamos en el apartado anterior sobre el título. El nombre del poema, "Arte poética", ya es suficientemente explícito. En él, Huidobro se refiere a la capacidad creadora de los poetas, que no han de conformarse con "cantar" -mimetizar- el mundo, sino que deben darle una nueva forma que ha de plasmarse en la estructura textual, en la integración de los planos gráfico y significativo, y en la relación de ambos con la manifestación del poeta.

Repárese concretamente los recursos visuales, que, como indicábamos en nuestra "Introducción", se manifiestan siempre en una asociación indisoluble con el aspecto semántico y metafórico de la composición. Para empezar, el segundo verso de la primera estrofa es más corto que los demás, y ello se relaciona con su contenido: "Que abra mil puertas"; el espacio en blanco recrea el espacio de las puertas abiertas. El verso siguiente anuncia el ligero escalonamiento posterior mediante los verbos "cae" y "volando", que encierran la idea de descenso. Además, la expresión "cuanto miren los ojos" se llena de sentido en este contexto, pues remite, por un lado, a la voluntad de creación del poeta y, por otro, a la naturaleza visual que el propio poema, como compendio de objetos creados, adquiere.

La segunda estrofa acaba con la palabra "mata", que se sitúa frente a "vida" formando una antítesis. La noción de fin que porta "mata" encuentra su correspondencia el espacio en blanco interestrófico.

El verso más corto de la tercera estrofa es "El músculo cuelga". Es cierto que el verbo "colgar", en principio, tendría un gran efecto en un verso largo, pero el hecho de que se asocie a un músculo aislado que carece de un todo justifica la longitud de este verso y el espacio en blanco resultante. El cuarto verso es el más largo, y ello confiere énfasis a su última palabra, "fuerza": los términos que aluden a un incremento de cantidad o medida determinan el crecimiento del verso, sobre todo si ocupan la posición final.

Por lo que respecta a la cuarta estrofa, llama especialmente la atención su última palabra, "Sol". Debido a la cortedad del verso anterior y al inmediato espacio en blanco interestrófico, el "Sol" creado ${ }^{18}$ por el poeta parece resplandecer en el verso. Una imagen muy visual, "Hacedla florecer [la rosa]", completa el valor gráfico de la estrofa y refuerza el contenido del texto.

Algo similar a lo que ocurría con "Sol" acontece con "Dios" en el verso que cierra el poema. Al término -que alude en este caso al creador, no a lo creado- se lo reviste de luz al colocarlo entre el espacio en blanco interestrófico anterior y el espacio en blanco que provoca el final del texto.

\footnotetext{
${ }^{18}$ Insistimos en ello: el aspecto visual adquiere más sentido al concebir la realidad poética como creación nueva, no como mera evocación; de hecho, el valor visual contribuye, como el aparato metafórico o la adjetivación ("El adjetivo, cuando no da vida, mata"), a la disociación entre lo creado y la realidad cotidiana, que "significa una mutilación del hombre" (Mitre, 1976: 84). Aplíquese, por tanto, la condición de 'creado' a cuantos elementos del poema se analizan aquí desde el punto de vista visual. Por otro lado, aunque este no es lugar para disertar sobre ello, no deben perderse de vista los ecos nietzscheanos que subyacen en la idea del poeta como hombre nuevo, creador de una realidad nueva.
} 


\section{3 "El espejo de agua"}

Mi espejo, corriente por las noches,

Se hace arroyo y se aleja de mi cuarto.

Mi espejo, más profundo que el orbe

Donde todos los cisnes se ahogaron.

Es un estanque verde en la muralla

$\mathrm{Y}$ en medio duerme tu desnudez anclada.

Sobre sus olas, bajo cielos sonámbulos,

Mis ensueños se alejan como barcos.

De pie en la popa siempre me veréis cantando.

Una rosa secreta se hincha en mi pecho

$\mathrm{Y}$ un ruiseñor ebrio aletea en mi dedo.

Este poema, que da nombre a todo el conjunto, ahonda en la reflexión sobre el poeta creador: "me veréis cantando"19. La agrupación de versos en pares -en terceto en el último caso- refuerza el carácter musical, pero también comporta un valor gráfico que se relaciona con el recorrido en dos direcciones de las "olas" a las que el poeta se refiere y sobre las que navegan sus "barcos". Esa idea de navegación se potencia con el verso más largo, el antepenúltimo, sobre el que el poeta parece navegar "en la popa [...] cantando". La palabra "popa" también parece jugar con la largura del verso, cuyo fin se identificaría con la proa del barco. La longitud del verso, por cierto, sólo es visual, pues no es el único verso del poema con trece sílabas.

Otros términos del poema aluden a la distancia o al movimiento $\mathrm{y}$, en consecuencia, se adecuan a la longitud de los versos, ninguno de los cuales tiene menos de diez sílabas: "corriente", "arroyo" y "aleja" en el primer par; "profundo" y "ahogaron" en el segundo; "muralla" y "anclada" en el cuarto; y, en fin, "cielos" y "alejan" en el quinto.

El sintagma “Mi espejo", además, refulge al colocarse al principio de dos estrofas que, por otra parte, al comenzar del mismo modo, remiten a la idea de 'reflejo', en la que confluyen las dos dimensiones propuestas, la del propio "espejo" y la del elemento líquido que sugieren "arroyo", "estanque", etcétera ${ }^{20}$. La palabra "desnudez", en el tercer par, también se aprovecha del espacio interestrófico. En la penúltima estrofa, la secuencia formada por "Sobre sus olas, bajo cielos" parece corresponderse también con el espacio interestrófico, que representaría el espacio existente entre las "olas" y los "cielos".

\footnotetext{
${ }^{19}$ Alusión que puede contemplarse en clave de mise-en-abyme (Goic, 1994: 179).

${ }^{20}$ Ahonda en ello Goic (1994), para llegar a conclusiones en torno a la representación del poeta en el texto (vid. n. anterior) y a su desarrollo metafórico: conciencia como elemento líquido, creaciones como barcos, etcétera, aunque sin entrar en consideraciones sobre la distribución espacial de los elementos.
} 


\section{4 "El hombre triste"}

Lloran voces sobre mi corazón...

No más pensar en nada.

Despierta el recuerdo y el dolor,

Tener cuidado con las puertas mal cerradas.

Las cosas se fatigan.

En la alcoba,

Detrás de la ventana donde el jardín se muere,

Las hojas lloran.

En la chimenea languidece el mundo.

Todo está obscuro,

Nada vive,

Tan sólo en el ocaso

Brillan los ojos del gato.

Sobre la ruta se alejaba un hombre.

El horizonte habla.

Detrás todo agonizaba.

La madre que murió sin decir nada

Trabaja en mi garganta.

Tu figura se ilumina al fuego

$\mathrm{Y}$ algo quiere salir.

El chorro de agua en el jardín.

Alguien tose en la otra pieza,

Una voz vieja.

¡Cuán lejos!

Un poco de muerte

Tiembla en los rincones.

En este poema, en consonancia con la tristeza a la que alude el título, encontramos varios términos vinculados a la soledad -noción de aislamiento- y a la muerte -noción de acabamiento. Muchos de ellos resaltan entre espacios en blanco, lo cual halla correspondencia con las nociones mencionadas. Es el caso de "nada" en la primera estrofa, que se sitúa al final del verso más corto. También ocurre con "muere" en la tercera estrofa, aunque en esta ocasión los espacios en blanco se producen por alargamiento del verso; ese alargamiento, además, se relaciona con la acción durativa a la que alude "se muere", que prolonga la acción de morir en el tiempo. Ocurre también con "vive" en la quinta estrofa, que porta un sentido negativo al asociarse con "nada" y conlleva de nuevo una referencia al aislamiento. En la octava estrofa aparece "salir" cerrando un verso corto que provoca otro gran espacio, identificado con esa salida. Y, en la última estrofa, se halla "muerte", aislada por la cortedad del verso y el espacio interestrófico. 
También aparecen significados de lejanía en el poema. La sexta estrofa, de verso único, expresa cómo "se alejaba un hombre", lo cual encaja con la largura y la unicidad del verso. Y en la penúltima estrofa, esa lejanía se marca aún más con el desplazamiento hacia la derecha del verso “¡Cuán lejos!”, que verdaderamente se aleja del comienzo natural de la línea. Los espacios superior, por la cortedad del verso anterior, e inferior, por la distancia interestrófica, aumentan la sensación de alejamiento.

\title{
2.5 "El hombre alegre"
}

\author{
No lloverá más, \\ Pero algunas lágrimas \\ Brillan aún en tus cabellos \\ Un hombre salta en el sol. \\ Sus ojos llenos del polvo de todos los caminos \\ Y su canción no brota de sus labios. \\ El día se rompe contra los vidrios \\ $\mathrm{Y}$ las angustias se desvanecen. \\ El universo \\ Es más claro que mi espejo. \\ El vuelo de los pájaros y el gritar de los niños \\ Es del mismo color,
}

Verde.

Sobre los árboles,

Más altos que el cielo,

Se oyen campanas al vuelo.

Al contrario de lo que ocurría en el anterior -los títulos son opuestos-, en este poema, profuso en espacios en blanco, abundan los términos asociados a la luz y al color: el poeta parece reconciliarse con lo que lo rodea y alude a ese mundo que, según sus criterios, no se debe cantar. Desde la perspectiva de Huidobro, por tanto, el poeta no describe la realidad, sino que construye con palabras una realidad nueva en la que se mezclan las perspectivas interior y exterior, espacial y temporal: el poeta enfrenta, visualmente, el "universo" y el particular "espejo" que resulta de sus versos ${ }^{21}$.

Desde ese punto de vista, el escalonamiento que constituye la primera estrofa remite a varios de los conceptos que aparecen en ella: la caída de la "lluvia" y las "lágrimas", si bien éstas son metafóricas, y también de los cabellos. El verso siguiente culmina en la palabra "sol", que, como ocurría en "Arte poética", se aprovecha de los espacios que recibe el verso aislado. Especialmente luminoso es, tras el espacio interestrófico, "El día se rompe contra los vidrios", y del mismo tipo de espacio se

${ }^{21}$ Cf. Barón (2007: 189-191). 
beneficia el término "desvanecen", que se desliza hacia el vacío. También relucen los vocablos "claro" y "espejo" a causa de la cortedad del verso anterior y, nuevamente, de la distancia interestrófica.

Por su largura, dos versos destacan en este poema, y ambos incorporan vocablos relacionados con el movimiento y la distancia. El primero de ellos, el verso quinto, se cierra con la palabra "caminos", cuya idea de distancia recorrida se refuerza con el morfema de plural; las palabras "llenos" y "todos", con significados de cantidad, contribuyen al apoyo visual. El verso undécimo, por su parte, fortalece su longitud mediante "El vuelo de los pájaros" 22 .

Aisladamente, como si de una pincelada se tratase, aparece "Verde", introducido por el "color" del verso anterior y escudado por los "árboles" del verso siguiente. Se trata de la palabra más resaltada del texto y, desde el punto de vista cromático, se halla rodeada de luz y claridad. En este punto, el poema se aproxima a la concepción de un cuadro, por cuanto puede percibirse como una combinación de colores: en medio, el "Verde", y, alrededor, destellos que "Brillan", "el sol”, "El día [que] se rompe contra los vidrios" y el "universo [...] claro". Un cuadro, de hecho, que no es otra cosa que la realidad singular que el poeta instaura. Cierto es que la composición presenta una gradación organizada de las percepciones, y que la versión del poema incluida en Horizon Carré rompe definitivamente con cualquier tipo de continuidad mimética ${ }^{23}$, pero ello no invalida la voluntad de aprovechamiento espacial en el texto.

En la última estrofa se juega con la posición de las "campanas al vuelo", pues se encuentran, desde el punto de vista visual, en la parte más baja del poema, pero, al mismo tiempo, se hallan "Sobre los árboles, / Más altos que el cielo". La noción de "vuelo", como en el caso anterior, se aprovecha de la posición saliente del verso.

\section{6 "Nocturno"}

Las horas resbalan lentamente

Como las gotas de agua por un vidrio.

Silencio nocturno.

El miedo se esparce por el aire

Y el viento llora en el estanque.

$¡ \mathrm{Oh} ! \ldots$

\footnotetext{
${ }^{22}$ La noción de "vuelo", muy involucrada -sirvan de muestra los versos aludidos- en el ritmo visual de los poemas de Huidobro, es especialmente significativa, por cuanto constituye una línea sólida para la consideración del conjunto de su poesía (vid. Mitre, 1976, especialmente el apartado "Poesía del vuelo"), y es bien visible en este poemario: "Se afirma [en El espejo de agua] el yo lírico y levanta el vuelo que hará de Huidobro el poeta del humanismo interplanetario" (Pizarro, 1993: 61).
}

${ }^{23}$ Cf. Barón (2007: 189-191). Ocurre también con “Otoño", “Nocturno", “Nocturno II" o "Alguien iba a nacer". 


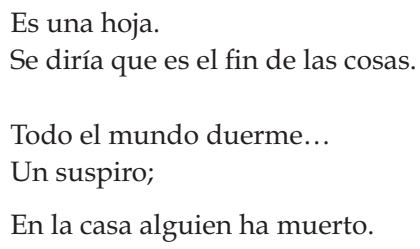

El título de este poema contrasta fuertemente con los términos luminosos, bien arropados por la disposición tipográfica, que veíamos en el poema anterior. Desde ese punto de vista, el poeta continúa jugando con la oposición de colores.

En la primera estrofa se alude al movimiento lento: "resbalan lentamente", y ello se corresponde tanto con el ritmo fónico -continuado- de los versos como con su largura. Algo parecido ocurre en la tercera estrofa, donde se alude al movimiento y al espacio: "se esparce por el aire", "el viento llora". Estos versos largos contrastan con el segundo, cuya cortedad, unida a los espacios interestróficos, refuerzan ese "Silencio nocturno", clave en la estructura del poema y su significado. Dicho silencio se quiebra con lo que se dice en otro verso corto, "Un suspiro", que, como también ocurre con "Es una hoja", parece tener lugar en un instante idóneo para el verso corto, con lo que la brevedad se manifiesta a la vez en el tiempo y en el espacio. Nuevamente, como en "El hombre triste", la muerte se coloca al final del poema: "ha muerto"; el espacio final proporciona la sensación visual de vacío y acabamiento.

\title{
2.7 "Otoño"
}

\author{
Guardo en mis ojos \\ El calor de tus lágrimas... \\ Las últimas, \\ Ya no llorarás más. \\ Por los caminos \\ Viene el otoño \\ Arrancando todas las hojas. \\ ¡Oh qué cansancio! \\ Una lluvia de alas \\ Cubre la tierra.
}

El otoño, estación a la que se dedica este poema, aparece justo en la mitad visual de la composición, en un ejemplo de cómo el motivo temático del texto puede colocarse estratégicamente. En el preludio a la venida del otoño, es decir, en la primera estrofa, encontramos un par de recursos visuales directos. En primer lugar, los puntos suspensivos sirven de correspondencia a las lágrimas aludidas, algo que también ocurría, aunque de forma metafórica, en "El hombre triste": "Lloran voces sobre mi corazón...". El verso más corto del poema, el tercero, comporta una idea de acabamiento que suele adecuarse a los versos breves, pues se refuerza con el mayor espacio que se crea tras su final: "Las últimas". 
En cuanto al verso más largo, en la segunda estrofa, se adecua a la representación del camino anunciado dos versos más arriba, y "Arrancando", por el carácter durativo del gerundio, comporta la idea de movimiento, que se acopla a la largura del verso.

El tedio al que alude el séptimo verso, “¡Oh qué cansancio!”, se ve reforzado por su condición de aislado.

En la última estrofa, en fin, el contenido se ajusta por completo a la distribución espacial: la "lluvia de alas" -nuevamente la noción de 'vuelo' al final del verso y rodeada de espacio- se halla encima de "la tierra", la "cubre".

\title{
2.8 "Nocturno II"
}

\author{
La pieza desierta; \\ Cerrada está la puerta; \\ Se siente irse la luz. \\ Las sombras salen de debajo de los muebles, \\ Y allá lejos, los objetos perdidos \\ Se ríen. \\ La noche. \\ La alcoba se inunda. \\ Estoy perdido. \\ Un grito lleno de angustia; \\ Nadie ha respondido.
}

Este segundo "Nocturno" presenta varias apelaciones visuales en sus versos. En primer lugar, se trata de un poema ciertamente descriptivo, por cuanto el poeta elabora un retrato de la estancia en la que se encuentra: "pieza desierta", "cerrada [...] puerta", "muebles", "alcoba". Varios términos, además, aluden a la oscuridad del lugar: "cerrada [...] puerta", "irse la luz", "Las sombras", "la noche".

El juego del tercer verso es doble. Por un lado, el espacio interestrófico potencia la idea de huída, ofrece una salida al verso. Si, además, lo que se va es "la luz", esta se asocia al hueco en blanco resultante. La aliteración de 's', por su parte, refuerza el ritmo fónico del verso y la noción de movimiento.

Pero el verso que más movimiento comporta es el siguiente, el cuarto, que, además, es el más largo del poema: "Las sombras salen de debajo de los muebles". La antítesis con "la luz" del verso anterior, y con el espacio interestrófico mencionado, otorga fuerza a la salida de "Las sombras". También existe aliteración de 's' al comienzo del verso, con idéntica función que en el anterior. En esa misma estrofa se encuentra uno de los dos versos trisílabos del poema, "Se ríen". Su cortedad y el espacio interestrófico inmediato aíslan esa risa de "los objetos perdidos" y la sitúan, en efecto, "Allá lejos".

El verso más enfatizado de la composición es el otro trisílabo, “La noche”. El énfasis que adquiere por ser el único verso aislado parece teñir de oscuridad a todo el 
poema, pues los espacios en blanco prolongan su efecto, en un juego cromático similar al que veíamos en "El hombre alegre" con "Verde". También encontramos el recurso en el primer "Nocturno" con el verso "Silencio nocturno".

La última estrofa presenta un juego gráfico muy interesante. El verso más corto, "Estoy perdido", al rodearse de otros más largos, representa al propio poeta dentro de la alcoba. El verso más largo, por su parte, incorpora un término que alude a la cantidad, "lleno", lo cual, como se ha visto en ejemplos anteriores, suele acomodarse a los versos largos. La largura de este verso, además, prolonga el "grito" de "angustia". Por último, el poema, como otros anteriores, se cierra con una alusión al aislamiento: "Nadie ha respondido", que da paso al espacio final.

\title{
2.9 "Año пиеvo"
}

\author{
El sueño de Jacob se ha realizado; \\ Un ojo se abre frente al espejo \\ Y las gentes que bajan a la tela \\ Arrojaron su carne como un abrigo viejo. \\ La película mil novecientos dieciséis \\ Sale de una caja. \\ La guerra europea. \\ Llueve sobre los espectadores \\ $\mathrm{Y}$ hay un ruido de temblores. \\ Hace frío. \\ Detrás de la sala \\ Un viejo ha rodado al vacío.
}

Esta visión más bien pesimista del cambio de año alude directamente al ámbito de lo visual. En concreto, el año nuevo se recibe como si de una película se tratase ${ }^{24}$. Se presenta el año, como se infiere del poema, marcado por la guerra -la Primera Guerra Mundial-, y Huidobro compara a los europeos con "espectadores" que contemplan el conflicto internacional. El segundo verso alude directamente a la clave de interpretación del texto: el lector ha de 'contemplar' el cambio de año que el poeta construye con sus versos en su "espejo" particular, de modo que la metáfora que supone todo el poema guarda una perfecta relación con la disposición de los versos en el espacio. Los planos espacial y temporal, interior y exterior se entrecruzan en el texto, lo cual da lugar a una exploración que relaciona el cambio de tiempo -y de tiempos- con la transmutación cinematográfica, que, al cabo, funciona también como espejo incorpóreo de la realidad

\footnotetext{
${ }^{24}$ Las vanguardias poéticas entablaron también estrechas relaciones con el cine. Al respecto, vid. V. Sánchez-Biosca (2004). Sobre la relación general entre cine y literatura, la bibliografía es amplísima. Vid., por ejemplo, Sánchez Noriega (2004).
} 
material, carnal; la percepción del poema, por tanto, obliga a la consideración conjunta de ambos niveles, espacial y temporal ${ }^{25}$.

Desde el punto de vista estrictamente gráfico, la primera estrofa, bastante uniforme en cuanto a la métrica de los versos, se corresponde con la "tela" en la que la película va a proyectarse. El último verso, ligeramente más largo, contiene la forma verbal "arrojaron", que porta un significado de desplazamiento, frecuente en versos largos, según se ha visto en muestras anteriores. Repárese también en la forma ligeramente semicircular que se crea tras los versos segundo y tercero, muy adecuada a la imagen del "ojo" que "se abre frente al espejo".

En la segunda estrofa, el primer verso parece salir del segundo, como si verdaderamente una tira de película cinematográfica se desenrollase desde su lata.

El primer verso aislado, por su parte, correspondería a la propia película, “La guerra europea", y de hecho podría pasar por el título de un filme, proyectado en este caso sobre los espacios en blanco que lo rodean.

En la estrofa siguiente, la lluvia "sobre los espectadores" se coloca en el primer verso, el plano superior, y los "temblores" -bajo los espectadores, se entiende- en el segundo verso, el plano inferior.

El antepenúltimo verso, "Hace frío", refuerza tal idea al no estar abrigado, es decir, al aparecer aislado en la estrofa.

Y, por último, en la última estrofa, el segundo verso es más largo que el primero, y ello contribuye al significado de movimiento que porta "ha rodado". Además, como ocurría en otras composiciones, el poema se cierra con un término que remite a la ausencia, "vacío", y que da paso, una vez más, al espacio en blanco final. El "viejo" al que alude la estrofa, por otra parte, se corresponde con el año que se acaba.

\subsection{0 "Alguien iba a nacer" \\ Algo roza los muros... \\ Un alma quiere nacer. \\ Ciega aún. \\ Alguien busca una puerta, \\ Mañana sus ojos mirarán. \\ Un ruido se ahoga en los tapices. \\ ¿Todavía no encuentras?}

\footnotetext{
${ }^{25}$ Cf. Goic (1994: 719 y ss.). Zonana (1992: 60) alude a este poema como muestra del concepto poético huidobriano: "La visión del poeta -el nuevo dios- posee un poder cognoscitivo revelador y oracular: manifiesta los lazos secretos que unen a las cosas entre sí y los da a conocer. En el doble movimiento del ojo que asume la realidad y la manifiesta luego transformada, el sujeto lírico parece responder a mecanismos de captación y proyección fílmica".
} 


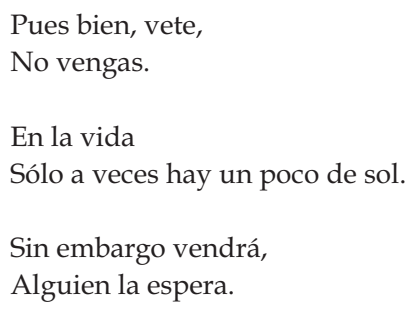

La idea de nacimiento que comporta este poema establece una antítesis con su posición final, procedimiento que constituye un recurso gráfico en sí mismo. Dicho nacimiento, por su parte, tiene que ver con el poeta que Huidobro reclamaba en "Arte poética", el texto que abre la obra. De este modo, el poemario queda cerrado mediante una estructura temática circular.

En cuanto a los recursos gráficos concretos, en el segundo verso existe una certera complementación entre "nacer" y el espacio interestrófico inmediato. Tras él, hallamos el verso aislado "Ciega aún", en el que el adverbio, en efecto, separa la ceguera de la luz que se produce mediante el aislamiento del verso.

El quinto verso anuncia que "Mañana sus ojos mirarán", y esa esperanza vuelve a estar representada por la distancia interestrófica. La duración del "ruido" del verso siguiente, por su parte, se prolonga gracias a su longitud.

El verso más largo del poema es el antepenúltimo, que se cierra con el término "sol"; este se beneficia, como ocurría en poemas anteriores, de la claridad que le aporta la longitud del verso y el espacio interestrófico posterior. Más apertura encuentra el último sintagma del poema: "la espera". Así, "Alguien iba a nacer" aporta un matiz de inminencia, convenientemente reforzado por los efectos descritos, a todo el poemario, que se erige como el anuncio del nuevo poeta.

\section{CONCLUSIÓN}

Este trabajo ha pretendido un acercamiento a El espejo de agua a través los valores gráficos que comporta, integrados en el ritmo -en sentido general- del poema y relacionados inevitablemente con sus significados. Este enfoque no excluye, por descontado, cualesquiera otros que se apliquen al estudio del poemario, según hemos apuntado, en parte, al remitir a determinadas referencias bibliográficas. Sería deseable, además, compendiar los significados de este tipo recursos en la totalidad de la obra poética de Huidobro, con el objetivo de sistematizar de manera más sólida los procedimientos empleados y aplicar las conclusiones resultantes a la consideración general de su texto poético.

Por otra parte, los significados de estos recursos visuales no tienen por qué ser exclusivos de la obra de Huidobro, sino que, en razón de su eficacia, pueden manifestarse en composiciones de otros poetas. Lo que hace singular al ritmo visual en los versos de Huidobro es su relación con las realidades creadas en su poesía; es decir, a la naturaleza de los objetos creados contribuyen -junto con la singularidad metafórica 
o las posibilidades fónicas- las especificidades visuales expresadas en los textos, que refuerzan los significados a los que el poeta llega. Así, si lo comparamos con otras de sus obras, fundamentalmente las posteriores ${ }^{26}$, El espejo de agua no es especialmente iconoclasta en cuanto a la forma se refiere: casi todos los versos comienzan a la misma altura; las rimas son abundantes, tanto las asonantes como las consonantes; se respeta la puntuación habitual; etcétera. Sin embargo, el poemario posee una carga visual muy considerable que completa los sentidos de los versos. En síntesis, el poeta aprovecha los espacios en blanco para arropar, fundamentalmente, dos nociones: la de acabamiento, en la que incluye términos como "muerto", "nadie", "vacío" o "soledad", y también "vuelo" o "salida", creando contextos en los que el blanco se corresponde con el espacio al que se 'sale' o 'vuela'; y la de luminosidad, en la que reúne vocablos como "sol", "luz", "espejo" o "fuego". Respecto de la longitud de los versos -que se relaciona inevitablemente con los espacios en blanco que provoca su variabilidad-, se comprueba que el verso largo alberga contenidos que implican duración, movimiento o intensidad, como "temblando", "fuerza", "caminos" o "arrojaron"; mientras que el verso corto ampara alusiones a la brevedad, como "suspiro", o incluso a la negación, como "No vengas", "No lloverá más" o "Nada vive" 27 . Como complemento, y desde un punto de vista más general, abundan los contrastes cromáticos, y pasamos de "el día" a "la noche", de "el sol" a "el ocaso", de "el fuego" a las "sombras", del "obscuro" al "verde", de "la muerte" a "la vida".

Pero la carga visual de El espejo de agua supera el recurso a efectos visuales concretos con composiciones que se acercan, incluso, al caligrama. Ocurre con "El hombre alegre" y "Año nuevo", pues en ambos textos todo se dispone para que, visualmente, el poema se corresponda con aquello que significa. En esencia, ese es el valor de toda la carga visual del poemario: el hecho de que los efectos gráficos contribuyan a la especificidad de la realidad creada por el poeta, que juega con la alternancia de los planos espacio-temporales y con el lugar que el sujeto ocupa en ellos. Al respecto, el título de la obra, según se ha mencionado ya, es clave, y coadyuva a su unicidad. Los poemas de El espejo de agua son muestras del universo al que el poeta da forma, mediante un uso de la lengua -de las palabras y de sus combinaciones- que desemboca en efectos visuales al servicio del desarrollo metafórico y la dispersión de significados. El poeta, el "Hombre-Dios" que evoluciona del "Hombre-Espejo" 28,

\footnotetext{
${ }^{26}$ Véase el somero análisis anterior de "Paysage". Al respecto, afirma Barón (2007: 187) que "Huidobro incorpora de forma íntegra la innovación que supone considerar la página como espacio de creación a partir de la publicación de Horizon Carré", y habla de "la disposición estrófica clásica de El espejo de agua", lo cual no impide, según se ha visto, el aprovechamiento de la página para el hallazgo de sentidos visuales.

${ }^{27}$ La negatividad e indeterminación se intensifican, según ha demostrado Barón (2007: 197 y ss.), en las versiones de Horizon Carré.

${ }^{28}$ En Mitre (1976: 85). Esa 'evolución' es nítidamente perceptible en ciertos textos de El espejo de agua. Barón (2007: 191), a propósito de "El hombre alegre", se refiere a "el sentido de ascensión [...], las características cósmicas de 'UN HOMME' [...], la unión virtual de ambas instancias, la del sujeto del poema con la de la figura del poeta cósmico". Aunque las palabras se refieren a la versión de Horizon Carré, en la que se "perfecciona la unidad de dicho enigma [cómo el locutor del poema puede llegar a ser poeta representable]", la relación entre las dos entidades, el sujeto ("mi espejo") y el poeta ("un hombre"), ya
} 
genera entidades, poemas, que deben ser mirados para su plena asimilación, y en ese punto conecta Huidobro, desde su concepción particular de la poesía, plenamente con las vanguardias y su precepto de imposibilidad de separación de las artes.

\section{BIBLIOGRAFÍA}

Aullón de Haro, P. (2000): La modernidad poética, la vanguardia y el creacionismo, Málaga, Universidad de Málaga.

Bajtín, M. M. (1982): Estética de la creación verbal, Madrid, Siglo Veintiuno.

Barón, J. (2007): "Huidobro: entre El espejo de agua, Nord-Sud y Horizon Carré", Cahiers du monde hispanique et luso-brésilien, 89, 185-204.

Calsamiglia Blancafort, H. y Tusón Valls, A. (1999): Las cosas del decir. Manual de análisis del discurso, Barcelona, Ariel.

Caracciolo Trejo, E. (1974): La poesía de Vicente Huidobro y la Vanguardia, Madrid, Gredos.

Cirlot, L. (1991): Las claves de las vanguardias artísticas del siglo XX, Barcelona, Ariel.

Corbacho Cortés, C. (1998): Literatura y arte: El tópico "Ut pictura poesis", Cáceres, Universidad de Extremadura.

Corbacho Cortés, C. (1999): Poesía y pintura en Manuel Machado, Cáceres, Universidad de Extremadura.

Costa, R. de (1975): Vicente Huidobro y el creacionismo, Madrid, Taurus.

Cózar, R. de (1991): Poesía e imagen. Formas difíciles de ingenio literario, Sevilla, El carro de la nieve.

Galán Rodríguez, C. (2001): "La ciencia como metáfora", Anuario de estudios filológicos, 24, 123-136.

Goic, C. (1994): “Vicente Huidobro, poesía de dos tiempos: 'perit ut vivat'”, Revista iberoamericana, 60, 715-722.

López Martínez, M. I. (1988): “Valores gráficos del verso libre en el grupo del 27 (I)”, Anuario de estudios filológicos, X, 231-251.

López Martínez, M. I. (1989): “Valores gráficos del verso libre en el grupo del 27 (II)”, Anuario de estudios filológicos, XI, 146-170.

Martín Ferrer, H. (1999): Ultraísmo, creacionismo, surrealismo: análisis textual, Málaga, Universidad de Málaga.

Mitre, E. (1976): “La imagen en Vicente Huidobro”, Revista iberoamericana, XLII 94, 7985.

Monegal, A. (1998): En los límites de la diferencia: poesía e imagen en las vanguardias hispánicas, Madrid, Tecnos.

está presente en el texto de El espejo de agua; Barón (2007: 196) ahonda en esta idea en relación con las versiones de "Alguien iba a nacer" y "El hombre triste": en "el tema de la crisis de identidad y del locutor como poeta", Horizon Carré alcanza "mayor grado que El espejo de agua". 
Montes, H. (1990): Vicente Huidobro. Antología poética, Madrid, Castalia.

Montes, H. (1976): Vicente Huidobro. Obras completas, Santiago de Chile, Andrés Bello.

Pizarro, A. (1993): "Para una nueva lectura de Huidobro", Canelobre, 25-25, 59-64.

Ramírez, J. A. (1991): El arte de las vanguardias, Madrid, Anaya.

Rojas, W. (2004): “El fechado dudoso de El espejo de agua a la luz de la tentativa poética francesa de Vicente Huidobro. ¿Un extravío del anhelo de originalidad radical?, Cahiers du monde hispanique et luso-brésilien, 82, 63-88.

Rutter, Frank (1977): “Huidobro y 'El espejo de agua': nuevas observaciones", Insula, 367,1 y 12.

Sánchez-Biosca, V. (2004): Cine y vanguardias artísticas: conflictos, encuentros, fronteras, Barcelona, Paidós.

Sánchez Noriega, J. L. (2004): De la literatura al cine: teoría y análisis de la adaptación, Barcelona, Paidós.

Schwart, J. (1991): Las vanguardias latinoamericanas: textos programáticos y críticos, Madrid, Cátedra.

Trancón, S. (2006): Teoría del teatro, Madrid, Fundamentos.

Yúdice, G. (1978): Vicente Huidobro y la motivación del lenguaje, Buenos Aires, Galerna.

Zonana, V. G. (1992): “Geografía ocular: elementos para una poética de la visión en la poesía de vanguardia hispanoamericana (Huidobro y Marechal)", Revista chilena de literatura, 40, 59-67. 



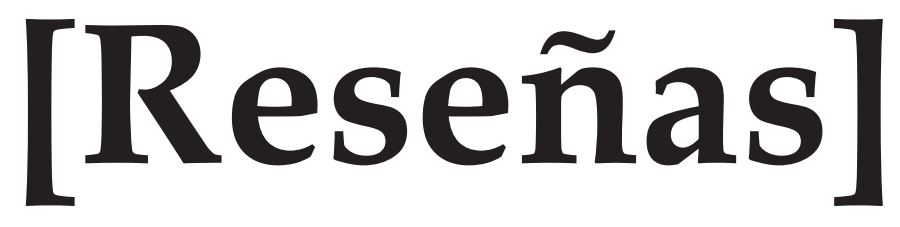





\section{Manuel Rico, Fugitiva ciudad, Madrid, Hiperión. Premio Internacional «Miguel Hernández-Comunidad Valenciana» 2012, 94 págs.}

Manuel Rico (Madrid, 1952) es uno de los poetas españoles más importantes actuales, y lo demuestra una larga trayectoria corroborada por una voz que con los años se ha ido asentado en el panorama siempre magmático de las generaciones y los estilos. Más allá precisamente de generaciones y estilos se encuentra su obra, en la que se inscriben títulos como Donde nunca hubo ángeles (2003), De viejas estaciones invernales (2006), y ahora Fugitiva ciudad (2012), el libro que aquí nos ocupa. Si algo ha demostrado Manuel Rico a lo largo de sus entregas, ha sido una independencia a través de la cual ha realizado una singular lectura de las últimas tradiciones en las que se han desarrollado las poéticas contemporáneas. Quizá desde esa óptica podríamos leer Fugitiva ciudad, un título que no ha pasado desapercibido a los lectores -recordemos que la poesía no tiene público pero sí lectores- por su alta intensidad emocional, su tensión ideológica -comprometida- y su crítica de todo lo que nos dejó ya para siempre y a lo que pertenecimos. Llama la atención, en ese sentido, las conexiones con La otra sentimentalidad -la corriente marxista granadina que luego se diluyó en la práctica sociológica de la poesía de la experiencia- que, más allá de una influencia, se plantea como una lectura personal de lo que significó la izquierda en una época, unas aspiraciones colectivas y unos planteamientos políticos que se compartieron en España a finales de los setenta y durante los ochenta, y que lejos de ser unos postulados «fechados», ahora podemos observar a las claras que de un modo u otro siguen vigentes siempre que alguien es capaz de actualizarlos y realizar poemas como los que nos ha regalado Rico. Lectura personal o, mejor dicho, relectura, por lo que implica de mirada retrospectiva hacia un tiempo ido, pero a la vez ejercicio personal de indagación histórica, en el seno de los debates del engagement y en la sentimentalidad de una época determinada, vivida de manera absolutamente personal y con aquellas claves generacionales que se compartieron entre la progresía de entonces. También una mirada a veces resignada, a veces enfadada, y otras melancólica, hacia un pasado que ha sido absorbido por una mentalidad posmoderna -instrumentalizada por un consumismo en el que se ha abolido el humanismo- en la que todo en lo que se creyó en un tiempo -la lucha utópica, las esperanzas colectivas, la creencia en una sociedad mejor y más justa- ha sido devorado por la indolencia del capitalismo tardío y el fin del sueño ilustrado.

Dicho esto, tanto por curiosidad estilística como por rasgo definitorio e identitario dentro de un marco de alto voltaje ideológico, la lectura de Fugitiva ciudad es un auténtico placer para el lector que busca poemas en los que haya vida, historia, aventura, anécdota, reflexión y emoción. El personaje principal que deambula por estos textos $-y$ que podríamos convenir que se identifica con el poeta, pero no necesariamente- se adentra en los años de la madurez y realiza una visión no siempre plácida de lo vivido, con la dignidad todavía erguida y con un puñado de buenas razones por las que sobrevivir y seguir luchando. Hay razones antiguas que siguen siendo válidas, a pesar de los tiempos de niebla que vivimos. Y, por cierto, la palabra 
«niebla» aparece muchas veces en Fugitiva ciudad, ciudad que huye literalmente, pero también que se confunde entre la niebla, ante nuestros ojos. Niebla que se repite, con su consecuente simbología, hasta el punto de que la voz poemática se defina como «hijo(s) de la niebla» (p. 82).

En el libro impera una narratividad de gran calibre, la cual va serpenteando por los versos de una manera rítmicamente ajustada, y que nos lleva de la mano durante toda la lectura de este conjunto de poemas. En muchas ocasiones asistimos más bien a fragmentos de un discurso ideológico, y podría establecerse fácilmente una relación entre narratividad y discursividad, ya que hay una extracción directa del pensamiento de izquierdas -en este caso no hegemónico- en sus contradicciones de hoy. Este discurso, bien elaborado y engarzado, con numerosos guiños intratextuales, temáticos y estructurales, pertenece a lo que Roland Barthes denominó «fragmentos de un discurso amoroso». Un discurso disperso por antonomasia, como podría ser esta estrofa...

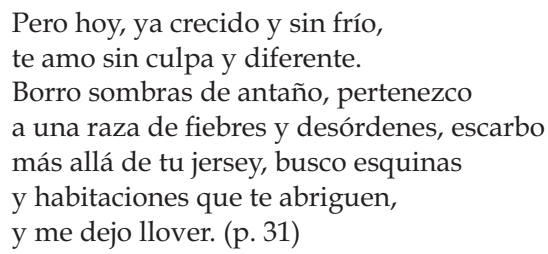

«Nebulosa» (pp. 13-14) luego aparece de nuevo en «Contra la Enciclopedia» (p. 21), y «Rémoras del origen» (pp. 16-17) posee una réplica en «Fin y principio de siglo» (p. 23), y, por citar otro, algunas nociones y conceptos de «Bukowski, Madrid, ella» (p. 25), luego se ven duplicados en «Certeza» (pp. 31-32). Podríamos señalar otros, pero las idas y venidas son una constante en esta primera parte del poemario, la más extensa, un rasgo que resalta la estructura estilística. Otras relaciones se podrían establecer en el sueño colectivo que una vez aunó a millones de trabajadores, y que se ve representado «En la tumba de Gramsci» (pp. 18-19), con «Berlín, 1989» (p. 22).

Los homenajes a Pier Paolo Pasolini, en ese sentido, son evidentes, cuando el autor monologa ante la tumba del pensador marxista sardo, muerto en las cárceles mussolinianas. De igual forma destaca el homenaje que se realiza a la Generación del 50, con las citas de Jaime Gil de Biedma en varios momentos de la cuarta parte, «IV. Formentor, medio siglo. 1959-2009», en una conexión con la izquierda de mediados de siglo y de unos planteamientos que, al menos poéticamente, cobran de nuevo actualidad. Hace falta mirar hacia atrás para rescatar lo que merece la pena de lo que dejamos. No todo el pasado, por ser ido, es peor. De hecho, Fugitiva ciudad vuelve una y otra vez hacia el tema urbano, un tema que revive ahora como en «Día no laborable en el polígono industrial» (p. 63), o en «El barrio que fue mío» (pp. 64-65). Ciudad, por tanto, con muchos recovecos y callejones, sótanos y cielos para descubrir y transitar, y que hay que recorrer en todo su esplendor. Manuel Rico nos ha entregado un libro necesario y útil, emocionante y lúcido, donde hemos podido hallar una voz que nos hacía falta. 
Clara I. Martínez Cantón, El ritmo como clave del verso en Antonio Colinas. Elementos rítmicos no métricos, León, Universidad de León Área de Publicaciones, 2013, 120 pp.

Los poetas en sus creaciones instauran mundos encerrados que contienen dentro de sí el poder de las palabras que sugieren más que explicitan y que evocan más que afirman. Ahora bien, la poesía no sólo consta de palabras o no es únicamente una sucesión de palabras ordenadas según unos determinados parámetros para producir un determinado goce estético sino que las composiciones poéticas guardan dentro de sí ciertas claves métricas y no métricas que se siguen o se transgreden. Precisamente, acerca de los elementos rítmicos no métricos localizados en poemas de Antonio Colinas trata el estudio de la investigadora Clara I. Martínez Cantón, El ritmo como clave del verso en Antonio Colinas. Elementos rítmicos no métricos, merecedor en la convocatoria de 2011 del XVI Premio “Mariano Rodríguez para Jóvenes Investigadores”. Tal y como reconoce Clara I. Martínez, "el estudio de los recursos rítmicos no métricos del verso resultaba muy atractivo, dado que [...] es un campo de suma importancia que rara vez es abordado, ya que los estudios poéticos suelen centrarse bien en el sentido o bien en la métrica". Sin embargo, los recursos rítmicos no métricos pueden aportar "mucho a la significación del poema. De ello surge la decisión de estudiarlos aplicados a la obra de un poeta". La elección de Antonio Colinas para ejemplificar las teorías de la investigadora se debe a preferencias personales o a la admiración expresa por la obra del poeta leonés.

Tras una introducción que avisa de los objetivos de la investigación, aparecen los apartados dedicados a la explicación teórica de los recursos rítmicos sistemáticos y no sistemáticos y, en concreto, los recursos que tienen que ver con la fonética, la sintaxis y la semántica rítmicas, sin olvidarse de los recursos visuales y del tono y la entonación. El estudio finaliza con una conclusión que supone una compilación de los presupuestos defendidos, así como la conveniencia de mejorar la presente investigación, relacionando "el uso de estos recursos rítmicos con el estudio de la métrica del autor".

De esta manera, los "complementos rítmicos", como los denominara Navarro Tomás, serían "elementos susceptibles de generar ritmo que son no constitutivos del verso, pero que puedan aparecer y contribuyen al ritmo y la musicalidad" en cualquiera de sus niveles -fónico, sintáctico y semántico-, como propone Domínguez Caparrós. Entre los recursos métricos no rítmicos se hallarían, según Clara I. Martínez, la entonación, el tono, aspectos visuales, etc., pues el objetivo del trabajo pasa por "realizar un análisis de estos fenómenos que apoyan el ritmo del verso, pero que no llegan a ser elementos métricos, dada su falta de sistematicidad".

La exhaustividad de la investigadora pasa por analizar los recursos métricos no rítmicos de los diferentes niveles, apoyados en ejemplos concretos extraídos 
de los poemas de Antonio Colinas. Así, entre los recursos de fonética rítmica trata la aliteración -con la que "se pretende crear una recurrencia fónica, que, en su caso más perfecto, se basa en el poder sugestivo de los sonidos, que concuerda con los contenidos que se manifiestan en el verso"-; o la paronomasia que "no tiene en la poesía de Colinas el sentido irónico que encontramos en otros poetas. Busca, por el contrario, la capacidad simbólica en la reiteración de palabras con semejantes". Por lo que se refiere a los recursos de sintaxis rítmica habla del paralelismo, la enumeración, el hipérbaton, el quiasmo, la anáfora, la epífora, la concatenación, pero también de la ausencia de puntuación que también afecta, aparte de a la sintaxis, "a la entonación y constituye además un elemento visual". Por su parte, en palabras de la autora, "los fenómenos ligados a la semántica nos incumben, dentro del campo del ritmo, siempre que haya una relación entre la significación de las palabras y la estructuración rítmica del lenguaje". Entre los fenómenos semánticos rítmicos trata la correlación o la repetición insistente de ciertas palabras pero no la metáfora, la sinestesia o la antítesis, "de gran valor significativo pero que no producen propiamente un ritmo, sino que aparecen de manera aislada" en los poemas de Colinas.

Por otro lado, en el apartado de los recursos visuales, Clara I. Martínez nos recuerda que, tal y como Martínez Fernández asevera, la poesía contemporánea "está fabricada y preparada para la lectura en soledad, lo que da cuenta de la importancia que los recursos visuales tienen actualmente". En el caso de Antonio Colinas sólo encontramos en su obra poética el recurso llamado "versos escalonados" o "línea poética escalonada", también llamado "verso partido" o "verso libre diseminado", según los autores. Esta variedad de denominaciones "dadas a este fenómeno nos hace ver que no es un recurso extraño en la poesía actual. En este trabajo nos inclinaremos por la denominación de escalonamiento o versos escalonados". Según la investigadora, "en Antonio Colinas no encontramos el escalonamiento como interrupción de unidades conjuntas, léxica o sintácticamente. No hay, podemos decir, una separación entre elementos cohesionados equivalentes a los que causarían encabalgamiento entre los versos que se presentan en escalera. Simplemente se realza la pausa, se le otorga más importancia". En realidad, este escalonamiento, así como la presencia de otros recursos gráficos, "son portadores de contenidos estilísticos y expresivos" porque suponen que el poema sea "visto antes que leído", colaborando "apreciablemente en el realce de la intensidad significativa del poema".

Por lo que respecta a la entonación, Clara I. Martínez admite que "es todavía un componente difícil de sistematizar para la lingüística debido en parte a su carácter suprasegmental. La entonación reúne valores expresivos (afectivos, etc.), hábitos lingüísticos (acento regional), y también funciones (interrogativa, exclamativa, dubitativa, etc.)". La investigadora considera "la entonación como un elemento rítmico que acompaña siempre al verso". No obstante, mantiene que la entonación sería "un impulso no absolutamente diferente al rítmico" pero no como "elemento fundamental del verso porque, aparte de repetirse uniformemente una unidad entonativa en cada verso, no encontramos factores que nos hagan pensar que el verso se organice, en la mayor parte de los casos, conforme a unos patrones entonativos regulares". Por 
ello, Clara I. Martínez finaliza este apartado reconociendo que "la entonación es un elemento muy rico en matices, que depende en buena parte de la lectura que demos a los textos, pero con ciertos puntos comunes para todo receptor, que pueden utilizarse en la poesía para resaltar determinados contenidos o darles una entonación concreta". Antonio Colinas prefiere usar en su obra "la tonalidad más expresiva de la exclamación y la interrogación, o incluso del paréntesis, en los momentos de más tensión emotiva".

Finalmente, en el último capítulo del libro, el referido a las conclusiones, la investigadora reitera que "el objetivo de este trabajo ha sido el estudio de aquellos recursos con incidencia en el ritmo poemático, pero sin carácter sistemático, es decir, sin función métrica". Asegura, asimismo, que Antonio Colinas usa los recursos fonéticos para intentar "crear una tensión entre sonido y sentido"; lo que también pretende conseguir a través del uso de los recursos sintácticos y semánticos, dada la importancia que "el autor otorga a la musicalidad y el ritmo en el poema". Sin duda alguna, estudios como el presente de Clara I. Martínez ayudan a resolver el análisis del ritmo característico de una composición concreta o de un autor en particular, lo que resulta clave para desentrañar la musicalidad que emerge de cada poema, pues, según el propio Colinas, "respirando con el ritmo del verso -del poema- existimos en el más alto grado de consciencia, sanamos y buscamos la liberación".

Nuria Sánchez Villadangos 



\section{Séneca Tragedias completas, Edición y traducción de Leonor Pérez Gómez, Madrid, Cátedra, 2012, 1.248 págs.}

El siglo I es el siglo de la Antigüedad -apasionante como pocos en la Historiaque más palpita del Imperio Romano, si bien cada momento histórico posee su interés específico y depende también de los gustos de quien se acerca a un periodo determinado. La literatura de ese siglo, la historiografía, las artes en general, la poesía -comenzando por Virgilio- y la épica, o cualquiera de los géneros que florecieron entonces, como los insuperables Epigramas de Marcial, la Farsalia de Lucano (a la sazón sobrino de Séneca), junto a los desmanes y perversidades de emperadores sádicos como Tiberio, Calígula o Nerón, sin olvidarnos de Domiciano, hacen de ese momento uno de los más atractivos y repugnantes, en general, en la Historia. Leer las Historias de Tácito o la Vida de los doce césares, de Suetonio, ya entrado el siglo II, nos demuestran que el siglo anterior tuvo que ser especialmente movido... tanto que su estela se funde con el final del siglo II y la muerte de Marco Aurelio, último gran emperador y filósofo. En medio de este marasmo de luchas intestinas, muertes y excesos de este siglo fundamental, Lucio Anneo Séneca, nacido en la antigua Córdoba a principios del siglo I y muerto en 65, hijo de Séneca el Viejo, conocido como orador -aunque quizá más como rétor-, también de origen hispano, fue un filósofo famoso en su época y, debido a eso, se granjeó no pocas envidias y admiraciones, amistades y enemistades. La figura de Séneca ha trascendido a su época como pocos filósofos y escritores, y su filosofía estoica, trufada de cierto epicureísmo, ha sido un referente a lo largo de la historia, sobre todo en la contemporaneidad. Expresiones populares como «ese hombre es un Séneca» demuestran el calado de un «personaje» que es bien conocido y ha sido un referente a lo largo de más de dos mil años en la historia universal, en concreto en Occidente. Incluso se habló de un hipotético cristianismo de Séneca, tal y como apunta la profesora Leonor Pérez Gómez en la Introducción de la obra que reseñamos:

También hay escritos de dudosa atribución o ciertamente espurios cuyo ejemplo más famoso es la supuesta correspondencia entre Séneca y Pablo de Tarso, producto de una leyenda que contribuyó a aumentar la reputación del filósofo durante la Edad Media. (p. 40)

Como se sabe, Séneca fue el preceptor de Nerón pero, al igual que los que rodearon al emperador tirano, acabó sufriéndolo en carne viva y el propio pupilo le pidió que se suicidara. Algunas representaciones pictóricas elevan la muerte de Séneca a la de otros filósofos antiguos como Sócrates. Agripina, la nueva esposa de Claudio tras el asesinato de Mesalina- y madre de Nerón, también acabó muriendo a manos de su propio hijo. Y así podríamos desarrollar un elenco nefando de muertes y crímenes innombrables. No hay que olvidar que las intrigas de Agripina, como asimismo habían sido las de Mesalina, estaban en sintonía con las usanzas sangrientas y monstruosas de sus predecesores, especialmente crueles a partir de Tiberio. Y recordemos que Nerón había llevado al circo a senadores y caballeros, echándose por tanto en contra 
a las oligarquías, que veían cómo para contentar al pueblo con medidas populistas y demagógicas, había cargado contra ellos, contra los estamentos más sagrados que fundamentaban la sociedad romana:

Apartándose de las propuestas aristocráticas, en las que la circulación de la literatura en general
y del teatro en particular había estado reducida a las élites cultas, Nerón atendió los gustos del
gran público multiplicando los espectáculos para el pueblo en un proceso en el que él mismo
no dudó en convertirse en actor, como tampoco en obligar a subir a escena o bajar a la arena del
circo a miembros de la aristocracia, caballeros y senadores que, en contra de su ancestral dignitas,
se convertían en diversión para el pueblo, contraviniendo sus más profundos prejuicios. (p. 15)

Así, la conjura para matar a Nerón estaba sirviéndose en los círculos palaciegos y de la alta sociedad romana de la que, por cierto, Séneca se había apartado en un retiro voluntario en 65, viendo quizá venir lo que se avecinaba. No obstante, de un modo u otro se vio envuelto en la conjura de Pisón, y lo cierto es que fueron muchos los que murieron a raíz de esta, entre ellos también Lucano, quien sí se sabe que había participado activamente, ya que el emperador -celoso de su poesía- le había prohibido publicar o recitar sus versos, por lo que acabó en los últimos años difamando y satirizándolo.

La historia de Séneca y del siglo I es realmente apasionante, como apasionantes son sus Tragedias completas, que ahora se presentan con una traducción asombrosa y un aparato crítico deslumbrante, y que hará las delicias de lectores aficionados o investigadores que deseen adentrarse en la época y en un lúcido análisis de lo que significan para la historia de la dramaturgia, de la tragedia y del drama en general (llegando hasta nosotros sus repercusiones), para el propio Séneca y para la época en la que fueron escritas. Sólo acercarnos a la Introducción que la profesora Leonor Pérez Gómez ha preparado para esta edición, y leernos las más de ciento veinte páginas, es un lujo. Y desconectamos de la «actualidad» leyendo con placer un texto que ha indagado en los mil y un recovecos de un autor y de unas obras que han sido durante más de dos milenios referencia, hoy convenientemente traducidas y puestas al día -«actualizadas»- en una traducción en la que no falta ni un detalle. Se trata, claro está, de eso.

De las diez tragedias que componen el corpus dramático que nos ha llegado, la mayoría son de influencia griega, de alto coturno, y la Octavia de origen romano, siendo su autoría de esta última la más discutida. Cada una de estas piezas posee una introducción enjundiosa a su vez, que mantendrá el interés y pondrá la guinda erudita a cada uno de los versos y laberintos textuales, filológicos, filosóficos o de algún otro tipo, entresacando lo más interesante de todo lo que se ha escrito sobre el asunto. Es asombroso, en ese sentido, la ingente cantidad de material recopilado.

Disfrutar de cualquiera de estas páginas -se trata de un volumen de más de 1.200 - es lo que cualquier amante de la lectura -releer en esta nueva versión- en español puede hacer a partir de ahora, en una edición económica y accesible en la prestigiosa editorial Cátedra: para aprender conceptos básicos de nuestra cultura, y seguir formándonos, o completar lagunas en otros casos, como la división ratio/furor (p. 50) que se ha propuesto por la crítica como uno de los motores de las tragedias, o 
plantear que precisamente el tema de las tragedias son las pasiones («En efecto, sin pasiones no hay tragedia», p. 52), y que estas eran la piedra de toque de los estoicos, para controlarlas, frenarlas (en cierto modo también ahí coincidían con los epicúreos, y más en el estoicismo al modo suo de Séneca, quien recabó lo mejor del filósofo de Samos). O interpretar algunas de estas obras como una crítica al poder desde alguien que siempre estuvo tan apegado al poder, desde una actitud ética que le guió y que definió en sus Cartas a Lucilio... Sea como fuere, su pensamiento, su figura, su trascendencia histórica, y sus tragedias ahora, forjaron un «personaje» que con el ejemplo encarnó una manera de vivir y pensar, rodeado de un halo de verdad y mesura, que no pudo impedir que Nerón acabara actuando con sevicia y que esta fuera la moneda de cambio de una sociedad que hoy vemos como admirable y detestable a la vez. Poco nos queda que añadir excepto recomendar esta magnífica edición y esta lectura, este arrebatador volumen en el que se nos puede ir media vida para leerlo, pero qué decir para traducirlo, editar sus miles de páginas, miles de notas a pie de página...

Juan Carlos Abril 



\section{Antonio Chas Aguión, Categorías poéticas minoritarias en el cancionero castellano del siglo XV, Alessandria, Edizioni dell'Orso, 2012, 171 pp.}

Antonio Chas Aguión, Profesor Titular de Literatura Española de la Universidad de Vigo, ha centrado su investigación en la literatura medieval española y, más concretamente en torno al siglo XV, con publicaciones como Amor y corte. La materia sentimental en las cuestiones poéticas del siglo XV, Juan Alfonso de Baena y los diálogos poéticos de su cancionero o Preguntas y respuestas en la poesía cancioneril castellana. La presente obra, Categorías poéticas minoritarias en el cancionero castellano del siglo XV, se sitúa como el cuarto volumen de la colección Medioevo Ispanico, dirigida por Pilar Lorenzo Gradín y dentro del proyecto Autores e textos galegos na poesía castelá medieval, subvencionado por la Xunta de Galicia.

Esta publicación presenta una actualización y avance del tema, por parte del autor, dada su declarada intención de volver en un futuro sobre el mismo, y en un contexto de creciente interés por parte de los estudiosos en torno a la poesía cancioneril, campo de estudio en el que aún existen importantes lagunas que han de ser rellenadas, como es el caso de la variedad y heterogeneidad de subtipos poéticos.

A lo largo de los siete capítulos que la integran, esta breve e interesante monografía acoge un pequeño y selecto muestrario de estas categorías poéticas cancioneriles minoritarias, agrupadas en tres secciones: de ingenio, de iure y de amore. Dentro de esta clasificación se encuadran piezas de poetas de cancionero de muy diferentes generaciones y orígenes como, entre otros, Villasandino, Mena, Santillana, los Manrique, Enzina, Pedro de Urrea...

La denominación de "minoritarias" del título, lejos de ser, en modo alguno, un marbete despectivo, hace alusión a que se trata de modalidades poéticas que, cuantitativamente, no alcanzaron tanta difusión en los cancioneros de la época como puede ser el caso de canciones, dezires, villancicos, preguntas y respuestas, romances... que, además, también han sido objeto de una atención mayor por parte de la crítica especializada.

El primer núcleo, de ingenio, integra tres capítulos correspondientes a tres subtipos poéticos definidos principalmente por presentar un componente de agudeza, además de un alto grado de habilidad técnica: perqués, adivinanzas y disputas burlescas. Todos ellos textos caracterizados por adoptar la estructura dialógica, ya sean diferentes poetas los interlocutores, como en las adivinanzas y disputas burlescas, ya sea un diálogo establecido por el poeta consigo mismo, como en muchos de los perqués. En todas estas composiciones se pone especialmente de manifiesto el carácter social y de juego que los hicieron tan populares como pasatiempo cortesano.

El segundo apartado, de iure, incluye dos categorías muy reveladoras de un importante rasgo de la poesía cancioneril, que es la capacidad para integrar materiales 
procedentes de muy diversas fuentes y que generalmente no se considera aptos para la composición literaria, en concreto aquí trata los procesos judiciales y los testamentos. Se trata de una demostración más de la incomparable creatividad y capacidad de experimentación que demuestran los poetas de los cancioneros, además de mostrar su increíble familiarización con la realidad jurídica de la época.

Por último, en de amore, Chas Aguión explora los géneros que utilizaron los distintos autores para plasmar las características de su específica concepción de la afectividad: los manuales de gentileza y las definiciones de amor. Los manuales incluyen una gran variedad de reflexiones, ya sean desde una óptica seria o bien paródica, sobre el comportamiento adecuado del galán en la corte, demostrando así el alto grado de codificación que habían alcanzado estos espacios a finales del siglo XV. Además de esto, los poetas exploran todas las perspectivas del fenómeno del amor, deteniéndose a enumerar sus efectos, propiedades, condiciones y consecuencias, en lo que se denominan "descripciones de amor".

Cada uno de estos siete capítulos, dedicados a cada tipo de composición, presenta una estructura similar, comenzando con un estado de la cuestión que, generalmente, sirve para poner de manifiesto la escasa información que ofrecen las preceptivas de la época y la escasa valoración ofrecida por los textos del momento. Así mismo, cuando es posible, el autor expone los antecedentes de la tipología en cuestión y elabora unas tablas que plasman de forma muy clara y reveladora aspectos tales como la difusión o el interés suscitado por estas categorías en distintos momentos de la evolución de la poesía cancioneril. Además, tiene en cuenta la necesidad de definir las particulares características de cada subconjunto, dado que mayoritariamente estas creaciones no están ligadas a ninguna métrica fija sino que se definen por su temática, a excepción del perqué.

Tras estas tres reveladoras categorías de la poética cancioneril minoritaria, se sitúa una bibliografía que, aún sin llevar la pretensión de ser una nómina exhaustiva de publicaciones en torno a la poesía de cancionero, sino tan solo la enumeración ordenada de las referencias citadas a lo largo de la obra, incluye un gran número de obras que muestran el gran rigor y dedicación con que el autor ha investigado el tema y preparado la publicación.

En definitiva, Categorías poéticas minoritarias en el cancionero castellano del siglo XV es una obra imprescindible para aquellos que quieran ahondar en el conocimiento de la poética cancioneril, especialmente en los aspectos menos conocidos y más descuidados por la crítica hasta ahora.

Ana María Mariño Arias 


\section{Rafael Fombellida, Violeta profundo, Sevilla, Renacimiento, 2012, 96 págs.}

Rafael Fombellida (Torrelavega, Cantabria, 1959) nos tiene acostumbrados a una poesía de intensidad en la que la palabra se condensa hasta crear una atmósfera con muchos matices semánticos. El choque y la concentración con las que obliga a las palabras produce esa polisemia. Sus obras más recientes han dado de qué hablar en los lectores y la crítica, como son Deudas de juego (2001), Norte magnético (2003) y Canción oscura (2007). Pero sin duda alguna en Violeta profundo, su última entrega, publicada en 2012, la poesía de Fombellida ha dado un salto de cualidad que el lector agradece, ya que en el mercado actual hay un índice de inflación editorial demasiado amplio, con tantos títulos flojos e insustanciales.

De este modo, el cambio en el conjunto de la trayectoria poética de Fombellida podría resumirse en torno a cuestiones de estructura, no tanto estilísticas -sigue predominando el endecasílabo blanco en tiradas de mediana extensión- sino en el sentido de que afectan a la estructura profunda del texto, dicho sea, de paso, parafraseando el título del poemario: la soltura rítmica de la mayor parte de Violeta profundo infiere otra narratividad -según estábamos acostumbrados- y todo eso puede ser explicado a partir de un raptus de altas dimensiones, que ha guiado al autor. Hay un antes y un después en la obra de Fombellida con este libro, y buena muestra de esto son poemas como «Colección particular» (pp. 41-42), «La cuenta del bebedor» (pp. 44-45), «Ailleurs» (pp. 46-47), «Arredor da illa» (p. 48), «Huir allá» (p. 49), «Quiet Song» (pp. 51-52), etcétera. Siguiendo con el endecasílabo blanco, en el que se han alternado raras veces otros metros impares, el poeta ensaya una estructura interna que va más allá del «corsé» elegido, con lo que el resultado no puede ser más feliz. Y precisamente el citado «Huir allá» podría indicarnos la intensidad del raptus, en el doble sentido de fuga y rapto, del binomio que crean evasión e inspiración. La vida -«Qué modesto es vivir, y qué poco se precia», nos dice el poeta en el mismo poemavivida como una aventura para protegernos de la indolencia y el aburrimiento, del tedio, de la cotidianidad insulsa y el nihilismo que nos recorre. La vida que tenemos y que, por tenerla, no apreciamos. Una vida en la que el amor es la piedra angular para disfrutarla. Plagado, por esto, de un hondo vitalismo, la visión última de los poemas suele estar matizada por un amargo pesimismo: «El mundo es un puñado de nieve y rodaduras, / una venta ciega, un lugar sin hogar.» (Ibíd.). Este podría ser el eje interno que motiva esa estructura y que otorga, en su combinación, ese ritmo distinto que hemos descubierto en el conjunto del libro. Así, habría una correspondencia entre la estructura formal elegida, las alternancias rítmicas señaladas, y las duras reflexiones y conclusiones a las que llega.

Porque llama la atención, y eso sí que no es nada nuevo en la poesía de Fombellida, la unidad temática -de fondo- del poemario, del que podríamos entresacar algunos de sus aspectos vertebradores, como podría ser el de la luz, a partir precisamente del título y de su referencia vespertina, contrapuesta al amanecer, la cual impone un tono crepuscular y decadente que impregna o forma parte de ese pesimismo aludido. 
La hora violeta, la hora en la que se inserta el libro, es la hora en la que las melancolías aparecen. Comienza también los miedos. No sólo nos adentramos en la noche sino que nos despedimos de la luz. La noche es ese lugar inhóspito cercano a la muerte, y el día solo puede ser su cara opuesta, la vida. Por eso la conciencia de ese atardecer nos sumerge en una conciencia desesperada y pasional, a veces necesaria, pero que nos daña: «Qué haría sin ti, sufrir, si te perdiera» (p. 19). La conciencia patológica en el sentido etimológico del término- del poeta conlleva una moral que, a pesar de todo, nos invita a vivir. Sin embargo, los poemas en los que la luz de la mañana apunta como benefactora, no ayudan demasiado, como por ejemplo, entre otros, el «Alba del renegado» (p. 24) o el «Alba del negligente» (p. 30): « ¿A qué has venido, alba, / sino para fijarnos en tu aplomo / y cantar tu balada sobre el ceño / de un arcángel mitad desobediente?» (Ibíd.) En medio de ambos textos se enmarca «Árbol de noche» (pp. 28-29), un canto a la oscuridad y a la mortalidad, a nuestra vulnerabilidad, donde aparecen algunos de los signos más destacados del poemario, como son la caducidad, el envejecimiento, la enfermedad, el vacío... «Árbol de noche, magno y crudo, este cúmulo / de mí se arropa en tu esplendor.», acaba. El díptico «La alondra, el ruiseñor» (pp. 34-35) vendría a resumir estas dos luces, que son las mismas pero en clave opuesta, y que simbolizan lo mismo pero enfrentadas, enfrentándose en la propia concepción de su origen, una que nace y otra que muere, si bien en «(La alondra)» (p. 34) la voz poética no se escuda en esperanzas vanas y por eso «Explicarlo es sencillo. Voy perdiendo / fe en el amanecer.» (ibíd.)

Llama también la atención que en muchos poemas el vocabulario elegido imprime a veces cierto feísmo que se traduce -entendemos- como crudeza, tal y como reza en el verso citado de «Árbol de noche». No es casual la elección de este material a veces desagradable y que pone una nota colorista y extravagante, como si de una pintura o texto expresionista se tratara. Orines, meados, heces, putrefacción, pústulas, llagas, etcétera, aparecen en numerosas ocasiones de manera consciente, entroncando con esa posible estampa de la miseria social como, entre otros, en «Consolación abajo»: «Esta ciudad, de noche, es peligrosa. / Hay navajas, trifulcas, borracheras» (p. 22), o en el «extrarradio» de "Quiet Song» (p. 51), que tiene mucho que ver con la miseria moral imperante. Hay una correlación evidente con la degradación del individuo -en su vertiente más material, corporal- y la degradación de la sociedad y del mundo, que se corrompe «casi» por naturaleza y sin remedio.

Para concluir nos gustaría resaltar que Violeta profundo se divide en dos partes conscientemente desequilibradas en cantidad de poemas, «1, Campo de Marte» $\mathrm{y}$ «2, La bella homicida». La arquitectura del libro habla por sí sola y ayuda en la interpretación del conjunto. En la primera parte se desarrolla esa lucha, y la segunda sería como una suerte de salida con reverberaciones góticas -al más puro estilo anglosajón- que hacen más atractiva la lectura global. El cambio estrófico que esta segunda parte posee, con unos poemas que se salen de la tónica del poemario, entronca con esos hallazgos rítmicos de la primera parte señalados, y ofrecen un contrapunto nada desdeñable. En suma, construcción textual y unidad formal son claves para leer un libro que a buen seguro llamará la atención de lectores y recomendamos vivamente. 
Manuel Cifo González (ed.) Las cuatro estaciones. Homenaje a Pedro García Montalvo, Murcia, Universidad de Murcia, 2013, 387 pp.

Los libros de homenajes no siempre consiguen el objetivo de dejar una semblanza del perfil intelectual del profesor que recibe el reconocimiento de sus compañeros y amigos. Puesto que se trata de una figura proyectada tanto en el aspecto de la crítica y del análisis del discurso narrativo como en la producción literaria en ese género, la forma de este libro parece servir al propósito de observar esa doble faceta de creador literario y maestro de la técnica de composición. Ciertamente las obras con las que ajusta el lenguaje en un estilo propio no solo han despertado interés entre el público lector, sino que han sido objeto de varios estudios. Por eso no sorprende la diferencia entre las contribuciones que se recogen para el homenaje. Por un lado, narraciones breves y una muestra poética; por otro, estudios críticos sobre las novelas y cuentos de García Montalvo; la técnica didáctica en un ámbito de búsqueda de métodos y resultados; finalmente, algunas contribuciones de temática literaria y retórica.

El título corresponde también a esa variedad que refleja las distintas facetas que proyectan la imagen de una actividad intelectual rica y compleja, al tiempo que rememora una colección de cuentos inaugural de la etapa de residencia literaria en Murcia: la primavera en viaje hacia el invierno. De otra parte, los estudios críticos dan cuenta de los rasgos que definen el movimiento literario de esa etapa de creación a la que se unió de manera entusiasta García Montalvo. Se trata de una narrativa descriptiva, con recursos que ralentizan el ritmo, novelas de personaje, en cuyas descripciones se potencia el simbolismo en diferentes planos. T. Albaladejo, A. Albertus, E. Morote, José Belmonte, T. Caro, M. González, C. Escudero, P. García, M. Martínez, J. L. Martínez, J. Orrizo, E. Sánchez Rosillo, y A. Trapiello explican como lectores y críticos su visión de la obra de García Montalvo. Desde la experiencia de los escritores de posguerra, la larga evolución de la literatura del siglo XX español se dibuja con sus accidentes propios. Pero también estos estudios dejan bien patente la fugaz presión de la literatura europea modelaba las formas narrativas que admiten antecedentes a veces lejanos, como son los de la literatura clásica o renacentista, otras, el gusto por las sensaciones compartidas a través de la recreación en palabras.

Algunos párrafos escritos por los amigos podrían servir para enriquecer una semblanza biográfica, pues cada uno recoge las impresiones que la memoria de cada cual atesora, un autor visto desde fuera de su obra, que viaja y evoluciona a medida que avanza en su viaje. Sin embargo, la relación de esta peripecia vital con la historia literaria en la que el escritor se ha insertado, proporcionará un acceso fácil a cuantos se interesen por esta obra narrativa. De ahí la utilidad que supera la anécdota, el homenaje, la circunstancia en que este libro aparece. 

Francisco Arenas Dolç (ed.) Retórica y democracia. Perspectivas críticas sobre el estado de la investigación, Valencia, Institució Alfons el Magnanim, 2012, 371 pp.

A más de treinta años de distancia del asentamiento de la democracia en España algunas voces se alzan reclamando una depuración de las adherencias que se le han ido incrustando en el engranaje de sus instituciones. Tal vez hoy lamentamos el descuido de la tendencia a la recuperación de la retórica parlamentaria en los primeros años, en los que el cuidado de la presentación de propuestas, del diálogo público entre opiniones diversas pretendía establecer una costumbre de respeto del lenguaje y de las formas expresivas.

Por eso el libro que presentamos es ante todo una llamada de atención sobre la función de la retórica en el cuidado de una democracia sana y útil para una adecuada gestión de los asuntos públicos. No solo la falta de argumentación, los titulares llamativos sin fondo argumental, y el adelgazamiento del vocabulario político desvirtúan el intercambio de ideas, sino sentencian por adelantado toda posibilidad de aceptar la posición de los que piensan diferente. Ciertamente es más fuerte el mal ejemplo de los políticos que presumen de demócratas y dan la espalada a los ideales que defendieron otros de buena fe. Pero salvada la coherencia entre lenguaje y comportamiento, el primero debería ser considerado una preferencia obligada de la convivencia social y de la actividad política.

En las primeras líneas del estudio preliminar se presenta la democracia bajo el rasgo de la cooperación. La diferencia entre el enfrentamiento dialéctico y la cooperación es evidente. El diálogo que ahonda en el conocimiento mutuo se enriquece en un grado superior con la cooperación que reconoce el valor de las diferentes personas y agentes sociales que presentan sus propuestas en la lealtad a un objetivo común. Sin duda este ideal ético no puede estar vacío. La educación en el respeto es todavía una asignatura pendiente en nuestra sociedad en la que muchos se consideran con derecho a atropellar a los demás. Por eso la aportación de este libro, desde la atalaya de la institución que lo publica, debe alcanzar los espacios y las mentes de los que todavía creen en los recursos de nuestra sociedad para construir una estructura de convivencia más sólida y resistente en el mar de intereses que, amparados en un reclamo de adaptación a la modernidad, rompen contra las más firmes convicciones.

El concepto de humanismo cívico que se comenta en sus páginas supone una recreación de un ideal de ciudadano participativo, que confía en una red de relaciones institucionales a la medida del hombre, permeables a las cambiantes situaciones que puedan sobrevenir. Pero para contrastar esta idea, el libro nos ofrece el contraste de aquellos fundamentos del desarrollo de la retórica que se encuentran en la Antigüedad. La Atenas clásica o la oratoria ciceroniana se erigen con un nuevo perfil para guiar nuestra reflexión sobre los problemas contemporáneos de nuestras democracias. Desde 
el punto de vista filosófico, la retórica ofrece una interpretación de la vida y del vivir (Jesús Conill) emergiendo de la poetización intrínseca, de la poetización vital. José Luis Ramírez corrobora esta aproximación a la capacidad humana para la retórica hasta la dimensión del ser humano como animal retórico. Si se trata de una realidad del ser humano, no es extraño que nos remontemos más allá en el tiempo y más lejos de los espacios de la Hélade antigua para encontrar esbozos de los valores que sostenían la autoridad del consejo de algunos miembros de la comunidad, cuyas consecuencias se trasladaban generación tras generación desde la invención de la literatura escrita en el IV y III milenio. De estos escritos deduce Luis Folgado Bernal las normas de preparación oratoria en Sumer.

Para el mundo griego, la habitual contundencia con que Francisco Rodríguez Adrados defiende la actualidad del primer impulso democrático europeo en la cuna de la civilización griega, se expresa de nuevo cuando recuerda la época de lealtad en la que no había "un hueco para extremistas y revolucionarios ni para independentistas". Tal vez en la deriva de nuestras democracias del siglo XX, no preparadas para contener las enormes injusticias sociales resultantes de las catástrofes y de las desigualdades han forzado la entrada patente a los defensores de los perjudicados por esos agravios. Una sociedad justa no necesitaría recordar los desastres del pasado. Sin embargo, el profesor Adrados explicaba muy bien la traición a los ideales éticos de la Atenas clásica que condujo a la derrota de la Guerra del Peloponeso y a la pérdida de la libertad de Grecia. La crítica de los grandes autores del teatro clásico podría haber evitado tales calamidades si hubiera sido escuchada. Precisamente en este género se desarrolló la argumentación y el uso del lenguaje en la discusión de posturas enfrentadas. El mensaje de este capítulo recuerda cómo el error humano, que no es un problema exclusivo de la ideología democrática (aunque sin duda lo que se entendía por democracia en la Antigüedad tiene importantes diferencias por lo que conocemos hoy con ese nombre) suele ser olvidado y no se corrige.

La deliberación política, que no es el constante en los medios de comunicación "sentarse a negociar", implica una preparación de los que intervienen en el debate para discutir la propuesta anunciada. De ahí que el profesor Arenas Dolç recurra a los pasajes del teatro griego para replantear en otra dimensión este diálogo necesario. Sin embargo reconoce esas diferencias de mentalidad y situación del individuo en el cuerpo social que eran propios de aquella antigua comunidad helénica, superados en nuestros días (argumentos de superioridad racial, oligarquía militar, preeminencia del discurso judicial sobre el deliberativo). Pero también advierte de otras condiciones del hombre actual, que desconfía de sí mismo, que obtiene una información confusa y tendenciosa sobre cuestiones que le afectan, que no se cree suficientemente capacitado para decidir lo que trasciende a otros, frente a los que a veces, desconocedores de esta larga evolución democrática, buscan en nuestro mundo un poder omnímodo como antaño.

Miguel Herrero de Jáuregui escribe un capítulo encabezado con la inquietante pregunta sobre la culpa. Un tema propio del teatro y de la cultura clásica griega que está tan enraizado en nuestra manera de vivir que desde niños buscamos causas y 
culpables para sentirnos seguros de los límites de nuestra responsabilidad. Más acuciante todavía sería para nosotros la culpa heredada, que nuestro individualismo y descargo de conciencia pretende olvidar para siempre como índice de las costumbres atrasadas o de las comunidades definidas por lazos de sangre y no por el libre albedrío. En efecto, en las sociedades antiguas este concepto tenía una indudable utilidad política: la amenaza a los descendientes era una garantía de legitimidad constitucional y de estabilidad, no solo un mecanismo de exclusión y un recurso de prevención de la venganza.

La síntesis admirable de la madurez de la cultura helénica y de la perspectiva práctica romana que logró expresar Cicerón en su producción intelectual se interpreta desde la retórica, la literatura y la filosofía con la agudeza de Jaime Siles. De la parte técnica del estilo discute la distinción del aticismo según la perspectiva meditada de los críticos. El aprovechamiento del vocabulario técnico literario por los teóricos romanos del estilo y por Cicerón en defensa de su forma de expresión y como historiador de la retórica romana es solo una muestra de la diversidad de posturas que una rápida lectura (si no apresurada) de los manuales no podría descubrir.

En Roma se asumen y sintetizan los principales recursos oratorios, una vez superado el tamiz de la ética pública. De ahí esa distancia respecto a la sofística que destaca Jorge Tárrega en su análisis de la preceptiva para valorar la admisión de la mentira como recurso en la oratoria romana. Los valores de la retórica deliberativa quedan a un lado a la vista de la práctica declamatoria que mostraba de otra manera la competencia en el ejercicio de la literatura no escrita desde antiguo. Representan otra faceta de la técnica de la expresión en público transmitida por la costumbre, ceñida al ejercicio constante de entrenamiento para depurar la actio, agilizar la memoria y variar el tono reinterpretando los textos. La perspectiva de Esteban Bérchez completa esta mirada a esta práctica.

La retórica de género judicial no queda marginada en estos estudios, sino que David Ros se interesa por la posibilidad de hablar en el senado republicano y en sus tribunales ante la sospecha de que algunos agentes destacados practicaran el obstruccionismo para favorecer los intereses de cierta facción. Xaverio Ballester sugiere la posibilidad, fundada en "concordancias lingüísticas", de que el Diálogo de los oradores se pudiera deber al genio de Quintiliano.

Un buen conocedor de la literatura, el humanista Juan Luis Vives parece moderar con su enseñanza la aplicación de la retórica a sociedades mucho más complejas que las antiguas. Estos humanistas abrieron camino al debate ético posterior con Guianbattista Vico y Hobbes sobre la autonomía del individuo respecto del Estado, una construcción que se iba afianzando de manera inevitable en el progreso de los pueblos. Por eso el estudio de Björn Hammar se complementa con los análisis sobre el auge contemporáneo de los medios de comunicación, impregnados de una cierta práctica retórica adaptada a la sociedad de masas, de Michael O’Mara y Lola Bañán.

La unidad de esta densa panorámica de la retórica desde puntos de vista éticos, filosóficos, sociales, históricos, críticos y lingüísticos se presenta con gran acierto 
tipográfico, que facilita la lectura. El cuidado filológico del editor ha previsto la coherencia del volumen y ha dispuesto un aviso de siglas que refrenda la precisión de la terminología y de las referencias.

Por todo ello considero que este libro brilla con luz propia entre las propuestas actuales para la comprensión de la naturaleza y función de la retórica.

María Asunción Sánchez Manzano 





